UNIVERSIDADE DE SÃO PAULO

FACULDADE DE ECONOMIA, ADMINISTRAÇÃO E CONTABILIDADE DEPARTAMENTO DE ADMINISTRAÇÃO PROGRAMA DE PÓS-GRADUAÇÃO EM ADMINISTRAÇÃO

PAULA SOUSA BRANT E MELO

A contribuição da competência política para a carreira, a reputação e a legitimação da liderança

SÃO PAULO 
Autorizo a reprodução e divulgação total ou parcial deste trabalho, por qualquer meio convencional ou eletrônico, para fins de estudo e pesquisa, desde que citada a fonte. Catalogação na publicação Serviço de Biblioteca e Documentação da Faculdade de Economia, administração e Contabilidade- Departamento de Administração da

Universidade de São Paulo

FICHA CATALOGRÁFICA

Elaborada pela Seção de Processamento Técnico do SBD/FEA/USP

Brant, Paula Sousa.

A contribuição da competência política para a carreira, a reputação e a legitimação da liderança / Paula Sousa Brant. -- São Paulo, 2017. $305 \mathrm{p}$.

Tese (Doutorado) - Universidade de São Paulo, 2017.

Orientador: Joel Souza Dutra.

1. Competência profissional - Política. 2. Liderança. 3. Reputação. 4. Carreira profissional. 5. Legitimidade. I. Universidade de São Paulo. Faculdade de Economia, Administração e Contabilidade. II. Título.

CDD - 331.1143 
PAULA SOUSA BRANT E MELO

\title{
A contribuição da competência política para a carreira, a reputação e a legitimação da liderança
}

\author{
Tese apresentada ao Departamento de \\ Administração, da Faculdade de Economia, \\ Administração e Contabilidade da Universidade \\ de São Paulo, como parte dos requisitos para a \\ obtenção do título de Doutora em Ciências. \\ Área de Concentração: Gestão de Pessoas \\ Orientador: Prof. Doutor Joel Souza Dutra
}

\section{Versão corrigida}

(Versão original disponível na Faculdade de Economia, Administração e Contabilidade)

SÃO PAULO 
Prof. Dr. Marco Antonio Zago

Reitor da Universidade de São Paulo

Prof. Dr. Adalberto Américo Fischmann

Diretor da Faculdade de Economia, Administração e Contabilidade

Prof. Dr. Roberto Sbragia

Chefe do Departamento de Administração

Prof. Dr. Moacir de Miranda Oliveira Júnior

Coordenador do Programa de Pós-Graduação em Administração 
Aos meus amores, Lucas e Guilherme, com carinho, amor $e$ gratidão pela presença em minha vida e motivação para realização deste trabalho. 



\section{AGRADECIMENTOS}

Este espaço é dedicado a todas as pessoas que participaram e contribuíram de alguma maneira para a realização desta pesquisa. Foram muitos anos dedicados ao Doutorado e esse suporte serviu para suavizar todas as dificuldades vivenciadas durante esse período.

Ao Prof. Dr. Joel Dutra pela confiança em mim depositada, fundamental para que eu pudesse enfrentar as dificuldades e desafios de abordar um tema ainda não explorado, e que acabou tornando essa experiência especialmente interessante e enriquecedora. Agradeço pela gentileza e generosidade de sempre, por tantos conhecimentos e sabedoria compartilhados e pelo exemplo de humildade. Obrigada por todas as conversas que tanto me confortaram nos momentos de dúvida e ansiedade. Nesses anos de convivência, minha admiração e respeito só aumentaram. Sinto-me honrada por ter tido o privilégio de receber suas orientações.

Agradeço à CAPES por acreditar neste projeto e torná-lo viável. Agradeço aos membros do grupo de estudos sobre liderança e processo sucessório da USP, pelo apoio e contribuições, em especial ao Luciano Venelli Costa, pela ajuda no processo de validação do instrumento de pesquisa. Obrigada a todos os profissionais da FEA-USP, que realizam suas atividades com empenho, orgulho e dedicação, de modo a facilitar todas as atividades necessárias dentro da instituição. A Elaise, pela ajuda de sempre e por tornar minhas peregrinações possíveis. Em especial, aos professores que muito me ensinaram, principalmente, aos professores Graziella Comini e Leonardo Trevisan, pelas contribuições durante a qualificação, que me fizeram buscar o aprimoramento constante deste trabalho.

Agradeço a todos os gestores entrevistados, pelo tempo cedido, pelas experiências compartilhadas e pelos ensinamentos. Seus depoimentos tornaram esta pesquisa notadamente atraente e única. Em especial, a Paulo Brant e Terezinha Sette, que sempre me ajudaram na realização das minhas pesquisas, fornecendo fontes e compartilhando ideias. À minha assistente de pesquisa Julia Brant, pela companhia e dedicação.

Aos meus irmãos, Rodrigo e Renata pela amizade, pelo apoio e pelo incentivo de sempre. Aos meus pais Ronaldo e Silvia, pelo amor, pela dedicação, pelos ensinamentos 
e pelo exemplo de ética, moral, humildade e dignidade que formaram quem eu sou. Vocês são o meu alicerce.

Ao meu marido Lucas, pelo seu amor, apoio incondicional e incentivo desde o início desta longa caminhada. Obrigada por ter confiado e apostado em mim, por ter apadrinhado a realização deste sonho. Agradeço por ter me dado suporte em todas as minhas crises, que não foram poucas, durante toda essa jornada. As palavras não são suficientes para expressar meus sentimentos e gratidão. Obrigada por enxergar e instigar-me a buscar sempre o que há de melhor em mim. Agradeço por ser meu companheiro de sonhos, de discussões, de reflexões, de paixões, de dúvidas, de dificuldades e também de muitas alegrias e felicidades. Você foi um dos principais responsáveis por esta conquista.

A Guilherme, meu filho, que chegou no meio deste processo, "bagunçando" tudo, e, ao mesmo tempo, colocando tudo que realmente importa e têm valor nesta vida nos seus devidos lugares. Obrigada por me fazer querer ser uma pessoa melhor a cada dia.

Enfim, agradeço a toda minha família, em toda a sua extensão, e aos amigos, pela compreensão durante a minha ausência nesse período e pelo apoio de sempre. 
“A paz não pode ser mantida pela força. Isso só pode ser conseguido pela compreensão."

Albert

Einstein

(1930) 



\section{RESUMO}

MELO, Paula Sousa Brant. A contribuição da competência política para a carreira, a reputação e a legitimidade da liderança. 2017. 260 f. Tese (Doutorado em Administração) - Faculdade de Economia, Administração e Contabilidade, FEA - Universidade de São Paulo, São Paulo, 2017.

O comportamento político é uma característica da vida nas organizações, no entanto é preciso reconhecer que diferentes gestores são mais ou menos efetivos no uso desse comportamento, como consequência de suas habilidades. A competência política é vista como fator crítico para a efetividade e o desenvolvimento da carreira de lideranças. Esta pesquisa visa compreender melhor essa competência, sua relação com o desenvolvimento na carreira, o aumento da reputação e a atribuição de legitimidade das lideranças no contexto das organizações brasileiras. Para tanto, foram utilizados métodos mistos (quantitativo e qualitativo). A pesquisa foi desenvolvida em duas etapas, sendo a primeira a validação de questionário pré-existente em inglês para o português, o qual possibilita a avaliação da competência política (obtiveram-se 200 questionários válidos). Na segunda etapa, foram realizadas entrevistas com 21 gestores, com um roteiro de 12 perguntas abertas e aplicação do questionário. As questões foram elaboradas com o objetivo de identificar como as organizações e os gestores brasileiros percebem o ambiente político e como eles se sentem em relação ao aspecto político da função do gestor e se as lideranças brasileiras se consideram politicamente competentes e como elas são percebidas por seus pares e superiores nesse quesito. Buscou-se ainda verificar se a competência política é reconhecida como uma competência importante e positiva para os gestores. Para tanto, explorou-se a perspectiva positiva da política nas organizações, nos sistemas de carreira e na liderança. Outro ponto avaliado foi se as descrições feitas pelos entrevistados a respeito da reputação e legitimidade podem ser associadas à caracterização de lideranças consideradas politicamente competentes. Embora a visão mais comum da política seja negativa, os resultados mostraram que os profissionais brasileiros reconhecem o ambiente político nas empresas, seus aspectos positivos e a importância da competência política no desenvolvimento de suas carreiras. $\mathrm{Na}$ conclusão, discutiram-se as contribuições da pesquisa, suas limitações e sugestões de estudos futuros.

Palavras-chave: Competência profissional. Liderança. Reputação. Carreira. Legitimidade. 


\begin{abstract}
The contribution of political skill to leader's career, reputation and legitimation of leadership
\end{abstract}

Although political behaviour is an intrinsic characteristic of organizations, it is necessary to recognize that different managers can use such a competence more or less effectively, according to their personal abilities. Political Skill is perceived as an essential aspect for the efficiency and the development of the leadership career. This research looks at such a competence and its relation to aspects as career development, increase in reputation and granting leadership legitimacy in the context of Brazilian organizations. To this end, mixed methods (qualitative and quantitative) were used. The research was carried in two stages, and the first one was the approval of a pre-existing questionnaire, translated from English into Portuguese, which allows the evaluation of political skill (we obtained 200 valid questionnaires). At the second stage, interviews were made with 21 managers, and they included a script of 12 open questions, as well as the completion of the questionnaire. The questions were created with the objective of identifying how Brazilian organizations and managers perceive the political environment and how they feel about the political aspect of the manager's role. Another debated issue was if Brazilian leaders consider themselves politically competent and how they are seen by their peers and superiors with regards to this matter. Besides that, another goal was to verify whether a political skill is recognized as an important and positive competence for managers. To do so, we looked into the positive outlook of politics in organizations, career systems and leadership. In addition, we evaluated whether the interviewees' descriptions of reputation and legitimacy could be associated with the characterization of politically skilled leaderships. Even though most were under negative impressions regarding politics, the results showed that Brazilian professionals recognize the political environment in companies, their positive aspects and the importance of political skill in the development of their careers. In the conclusion further contributions of the research will be discussed, as well as its limitations and suggestions for future studies.

Keywords: professional competence; political skill; leadership; reputation; career; legitimacy. 


\section{LISTA DE FIGURAS}

Figura 1 - Antecedentes das dimensões da Competência Política

Figura 2 - Estrutura meta-teórica da Competência Política

Figura 3 - Modelo Processo político da liderança 


\section{LISTA DE TABELAS}

Tabela 1 - Análise de convergência

Tabela 2 - Cargas cruzadas

Tabela 3 - Critério

Tabela 4 - Entrevistas Profissionais Estudo de Caso 1

Tabela 5 - Entrevistas Profissionais Estudo de Caso 2

Tabela 6 - Entrevistas Profissionais Experientes

Tabela 7 - Geral entrevistas Gestores

Tabela 8 - Geral avaliação das dimensões competência política

Tabela 9 - Estatísticas básicas - respostas competência política

Tabela 10 - Estatísticas comparativas entre grupos de entrevistados 


\section{LISTA DE QUADROS}

Quadro 1: Fatores e itens da Escala de Competência política validada no Brasil Quadro 2 - Estudo de Caso 1

Quadro 3 - Estudo de Caso 2

Quadro 4 - Respostas pergunta 6 - Identifique uma situação que precisou de Competência política

Quadro 5 - Comparativo avaliação competência política - Estudo de Caso 1

Quadro 6 - Comparativo avaliação competência política - Estudo de Caso 2 



\section{SUMÁRIO}

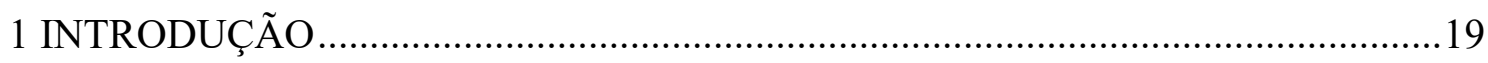

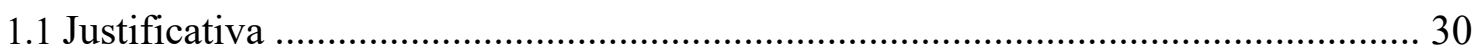

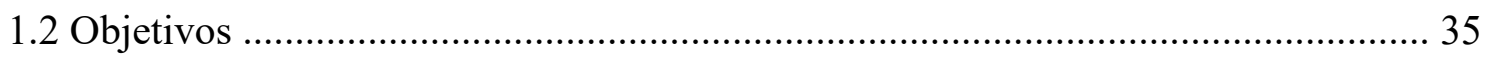

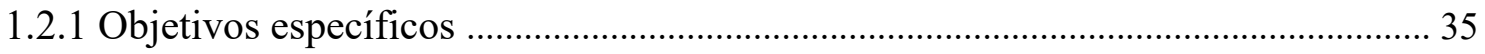

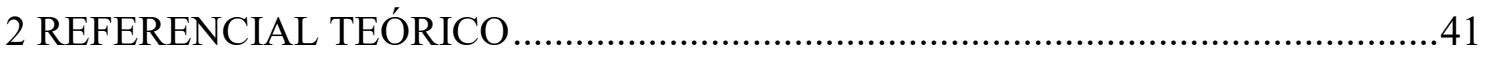

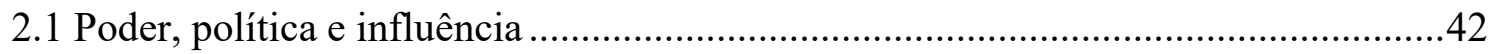

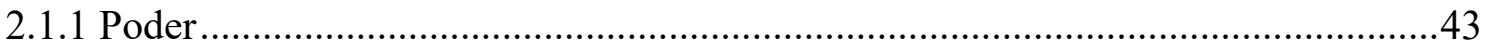

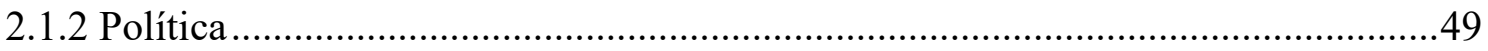

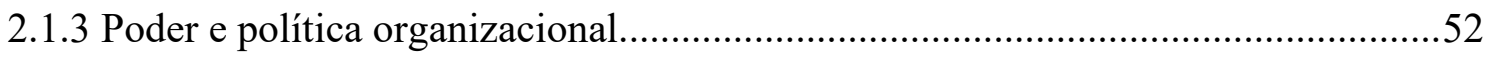

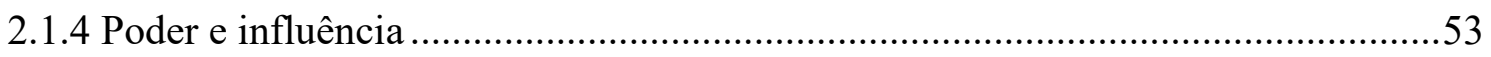

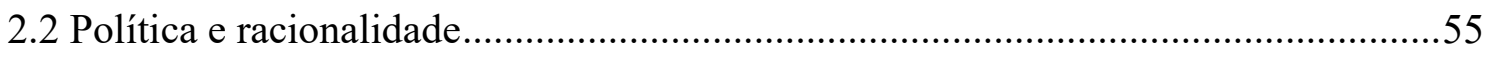

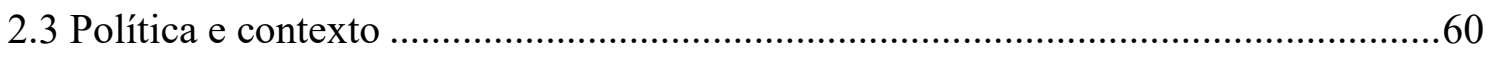

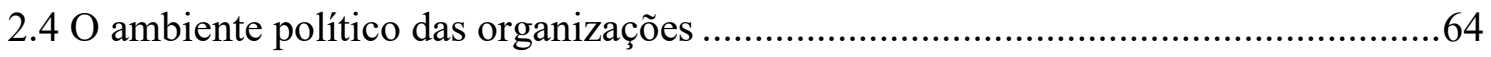

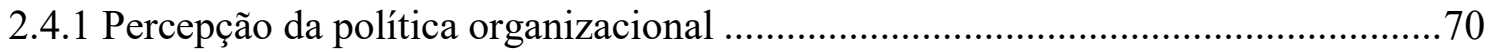

2.4.2 Perspectiva positiva da política nas organizações ................................................. 75

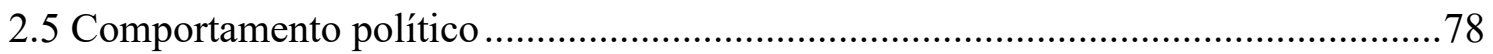

2.5.1 Motivações para o comportamento político (vontade política) ..............................85

2.5.2 Determinantes do comportamento político ...................................................... 86

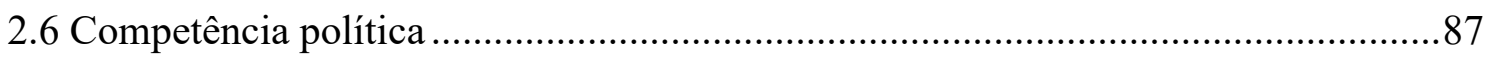

2.6.1 Dimensões da competência política .............................................................. 95

2.6.2 Antecedentes da competência política..........................................................99

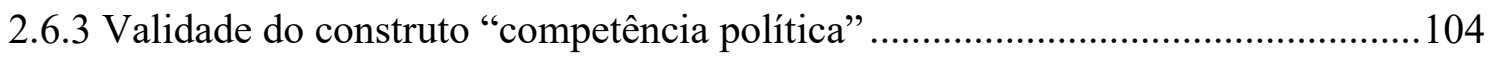

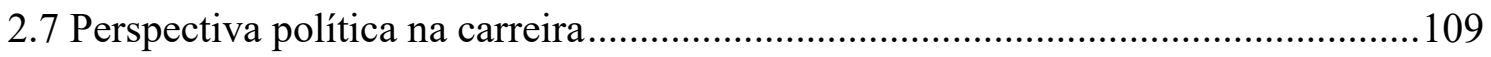

2.8 Perspectiva positiva da política na carreira ....................................................... 112

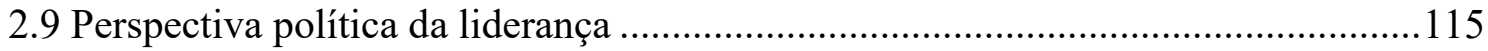


2.10 Perspectiva positiva da política na liderança.................................................... 119

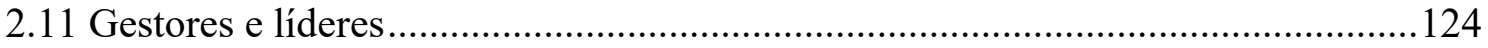

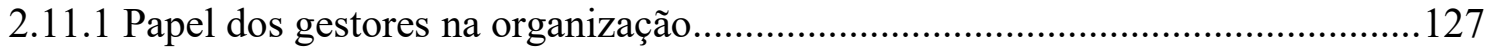

2.11.2 Papel das lideranças na organização................................................................ 131

2.12 Possíveis resultados da competência política ......................................................... 133

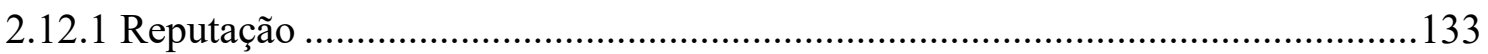

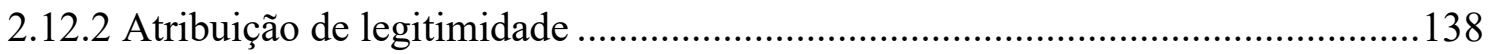

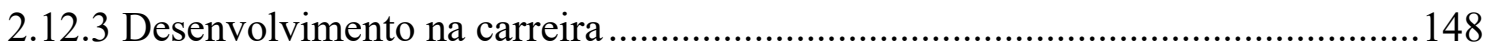

2.13 Teorias sociais que contribuem para compreensão da temática ..........................152

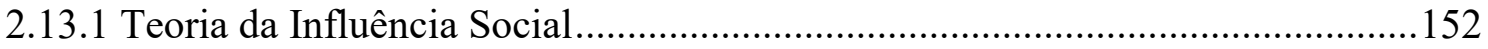

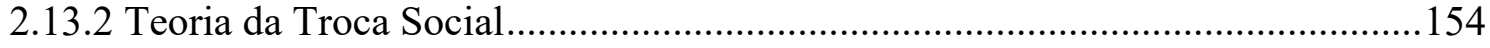

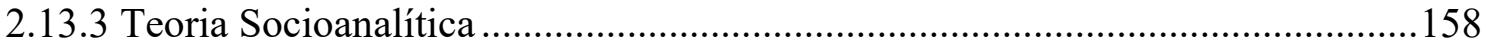

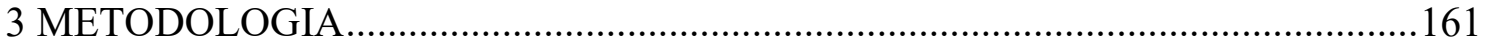

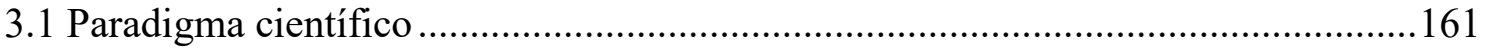

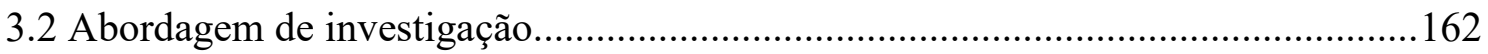

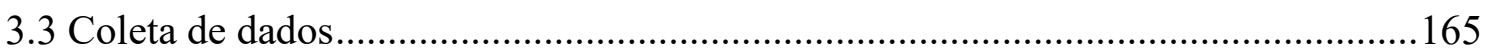

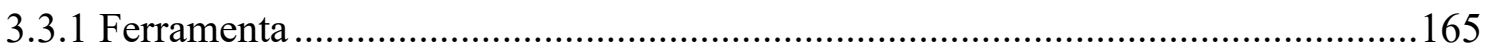

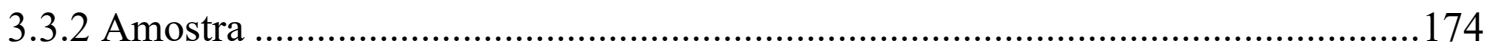

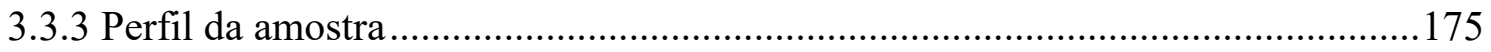

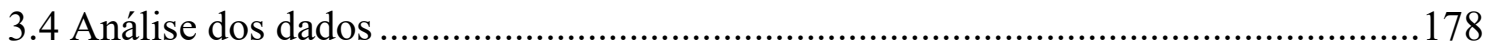

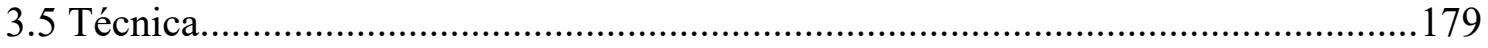

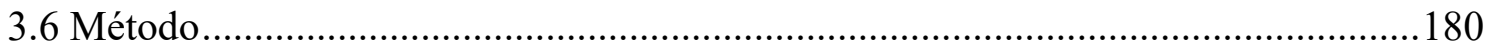

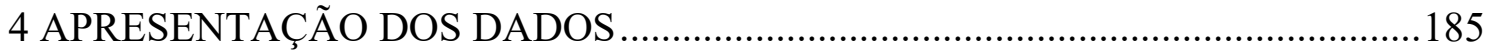

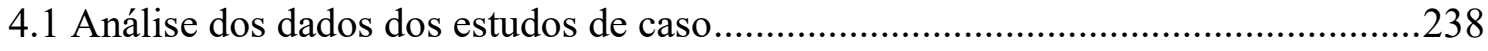

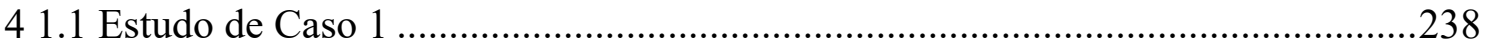

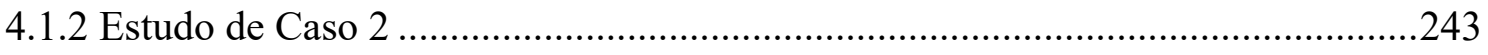

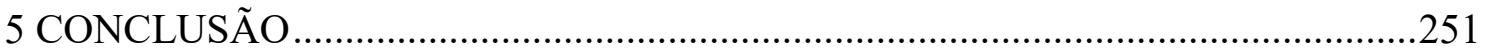




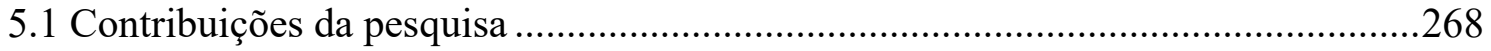

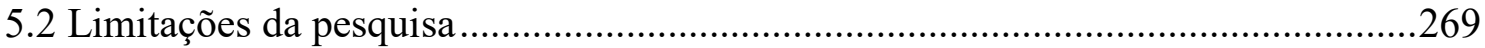

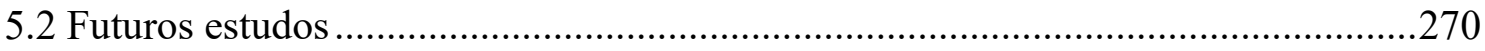

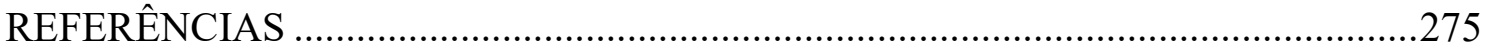

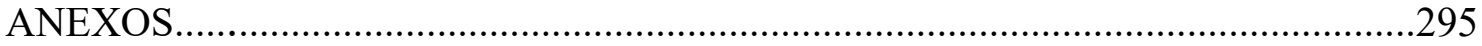





\section{INTRODUÇÃO}

Por que alguns profissionais bons tecnicamente não são promovidos? Por que determinados empregados fracassam ao assumirem cargos gerenciais? Por que conhecer pessoas-chave na organização pode contribuir para o desenvolvimento na carreira? Por que a opinião de certos profissionais parece pesar mais do que a de outros? Por que é importante obter o apoio de algumas pessoas na empresa? A realidade nas organizações mostra que nem sempre o profissional mais qualificado tecnicamente recebe a oferta de trabalho ou promoção, que a avaliação de desempenho nem sempre reflete a performance real do trabalhador, que muitas reuniões são definidas antes mesmo que aconteçam. Essas inconsistências sugerem que a política e o exercício da influência nas organizações podem tecer as práticas e o sistema de Recursos Humanos, como seleção, avaliação de desempenho, definição de salários e promoções.

Apesar de as teorias organizacionais baseadas nos modelos racionais fornecerem uma simplificação útil sobre a realidade organizacional, inevitavelmente, elas explicam apenas uma parte do comportamento presente nas empresas. A vida nas organizações envolve contradições originadas de duas realidades: a racional e a política. Mesmo que essas duas realidades possam apresentar contradições, frequentemente, elas também se complementam. Os membros de uma corporação, ao mesmo tempo em que atuam como cooperadores de uma mesma organização são rivais, ao competirem por recursos e reconhecimento (MILES, 1980).

Pfeffer (1992) considera que, frequentemente, a consequência das ações e escolhas nas organizações, tem sua origem no poder simbólico, ou seja, nas ações políticas que são tomadas para interferir na maneira como as pessoas se sentem em relação a uma situação. A dinâmica das organizações não pode ser vista apenas em termos de quem ganha, quem perde e os custos associados a isso, apesar de essas serem considerações importantes. Esse autor cita Murray (1964) que afirma que a análise política deve ser feita em dois níveis simultaneamente. Segundo este, é preciso examinar como as ações políticas fazem com que um grupo atinja os seus interesses e, ao mesmo tempo, como essas mesmas ações afetam o público em geral e ganham significado para ele e como esse público é aplacado ou despertado por elas. Para Pfeffer (1992), na maioria das empresas, os treinamentos e o desenvolvimento de competências são focados na capacidade de tomar decisões conforme os modelos de escolhas racionais (como a lógica e as técnicas analíticas). A política nas organizações lida com 
aspectos inerentes à natureza humana que são as divergências de interesses e os valores que, por sua vez, geram conflitos e disputas.

Apesar de a política ser um tema central e ter uma função cotidiana nas organizações, existe, nos jornais e periódicos de gestão, uma escassez de pesquisas teóricas e empíricas focadas diretamente na política nas organizações. A política nas organizações é um fato, no entanto esse aspecto da realidade das organizações permanece pouco abordado, podendo ser considerado um tabu (LEPISTO; PRATT, 2012). Três obstáculos contribuem para essa escassez, segundo Lepisto e Pratt (2012). Primeiro, o entendimento sobre política nas organizações ocorre de forma fragmentada na literatura organizacional. A política é frequentemente utilizada nas pesquisas relacionadas a temas como poder, redes sociais, coalizões, tomada de decisão, times de altos executivos, táticas de influência social, sendo que cada uma delas oferece um ângulo diferente na sua compreensão e normalmente ocorre pouca interação entre esses diferentes campos de pesquisa. Segundo, a maioria das pesquisas realizadas invoca a política organizacional, mas frequentemente o faz como um foco alternativo de estudo. As pesquisas sobre política tendem a enfatizar os antecedentes e resultados do comportamento político, contudo o conhecimento sobre o que a política faz no papel de suporte na mobilização das coalizões, na melhoria da posição pessoal, na tomada de decisão, no fazer coisas acontecerem tende a ser ofuscado. O terceiro obstáculo é o número vertiginoso de definições e conceituações sobre o tema, quase equivalente ao número de artigos sobre o tópico. Neste trabalho, a política será tratada como tema central do estudo.

Miranda (2009) elaborou um artigo com o título "O tabu do poder e da política nos estudos organizacionais". Esse artigo teve o objetivo discutir as principais razões que estão por trás da tímida e escassa produção teórica e empírica sobre poder e política em cenários de trabalho. A autora salienta que, ao ignorar a inevitabilidade do poder e da política, omite-se uma das mais reveladoras e determinantes peças do quebra cabeça organizacional. A verdade é que, durante décadas, parcas foram as pesquisas e os estudos realizados sobre os temas do poder e da política. Os manuais da disciplina ignoraram por completo essas temáticas, ou então as tratam de forma simplista, ingênua e incipiente, remetendo-as para umas breves e irrisórias notas laterais. Essa subvalorização, segundo essa autora, é passível de explicação por duas grandes ordens de razões. Primeiramente, em razão da perspectiva racionalista, cuja lente do paradigma funcionalista e racionalista tornou-se o modus operandi dominante em ciência 
organizacional no século XX. Essa visão racional vê o poder como equivalente ao exercício de autoridade. Nela, depara-se com uma concepção do homem organizacional, desprovido de ambições, invejas e interesses pessoais, trabalhando com afinco pelo objetivo comum. Nesse sentido, qualquer comportamento humano que escapasse à autoridade formal e se situasse fora dos arranjos organizacionais era visto como desestabilizador e disfuncional. Outro fator explicativo refere-se à má reputação dos dois termos e a conotação extremamente negativa associada a eles. Para Crozier (1973) e Kanter (1979), a essência dessa conotação negativa é um tabu moral. Esse reconhecimento da faceta "feia" e "suja" do poder e da política prolifera nos mais diversos domínios da sociedade. A atividade política, segundo Miranda (2009), é uma inevitabilidade das organizações, sendo irrealista rejeitá-la em bloco, como se toda ação política fosse negativa. Para essa autora, apesar dos avanços registrados nos últimos anos, permanecem por explorar e "colorir" inúmeras áreas cinzentas dos estudos organizacionais sobre o tema, havendo um grande espaço de progressão. Trata-se de uma das áreas de mais difícil investigação devido à sua sensibilidade e complexa conceituação e operacionalização.

Pfeffer (1992) entende que existe um medo do lado emocional da vida e um desconforto em ler ou discutir sobre o uso da política. O aspecto humano, muitas vezes, é deixado de lado. Para esse autor, as pessoas não são como computadores, suas emoções e sentimentos são componentes importantes para suas escolhas e atividades. Esse parece ser um lado das relações humanas que envergonha e que as pessoas gostariam de fingir que não existe. Contudo negar sua existência deixa os indivíduos mais suscetíveis aos apelos emocionais, pois pessoas desprevenidas são mais facilmente afetadas.

Em sua essência, a política e o poder não são maus nem bons, o uso que deles se faz é que determinará tais apreciações. Por essa razão, McClelland (1970) identificou as duas faces do poder - a positiva e a negativa. No seu entender, embora a conotação negativa seja mais comumente associada ao conceito de poder, é pelo uso deste que o mundo avança e progride. A faceta negativa do poder diz respeito a uma necessidade primitiva de dominar os outros por meio da submissão. A versão positiva do poder prende-se à vontade de iniciar, influenciar e liderar. Segundo esse autor, na maioria das organizações, prevalece a dimensão positiva do poder.

Ao negar as questões sobre poder e política nas organizações, deixa-se de avaliar uma parte importante das interações humanas no contexto organizacional. Essa negação 
vai de encontro ao pensamento complexo de Morin (1999, 2002), que vê o mundo como um todo indissociável. $\mathrm{O}$ autor propõe uma abordagem multidisciplinar $\mathrm{e}$ multirreferenciada para a construção do conhecimento. A complexidade apresenta-se com os traços inquietantes da confusão, do inextricável, da desordem no caos, da ambiguidade e da incerteza. Daí a necessidade, para o conhecimento, de pôr ordem nos fenômenos, ou seja, de rejeitar a desordem, de afastar o incerto, de retirar a ambiguidade, de clarificar, de distinguir e de hierarquizar. No entanto, esse autor alerta para o fato de que tais operações, necessárias à inteligibilidade, correm o risco de cegar o conhecimento ao eliminarem os outros caracteres do complexus. A proposta da complexidade é a abordagem transdisciplinar dos fenômenos e de mudança de paradigma. Para Morin (1999, 2002), a parte está no todo, assim como o todo está na parte.

Segundo Mangham (1979), quando existe um espaço de escolha quanto a uma direção nas organizações complexas, pessoas razoáveis irão discordar acerca dos meios e dos fins, e pessoas razoáveis irão, igualmente, lutar por aquilo que acreditam ser o curso certo da ação. A maioria das decisões organizacionais significativas é o resultado de um processo político e social. Isso significa que a imprevisibilidade e a elevada velocidade do contexto organizacional abriu um largo caminho aos jogos de poder e à movimentação política. Para esse autor, quem não for politicamente habilidoso ou se recusar a jogar o jogo do poder e da política fracassará irremediavelmente.

Esse tema passou a ganhar mais atenção, na atualidade, justamente quando o conceito de racionalidade organizacional foi desafiado em razão da emergência da compreensão da inadequação pessoa/organização e a incompatibilidade entre os objetivos pessoais e organizacionais. Uma visão realista da vida nas organizações mostrou a existência de objetivos conflitantes dentro da organização. Teóricos organizacionais têm defendido a importância de alinhar os objetivos pessoais com os objetivos da organização (VIGODA-GADOT; DORY, 2006; ULHA; JAFRI; DOST, 2011; LEPISTO; PRATT, 2012).

Segundo Morgan (1996), quando se fala em interesses, está-se falando de predisposições que englobam metas, valores, desejos, expectativas e outras orientações e inclinações que levam as pessoas a agirem de determinado modo. A tendência é pensar em interesses como áreas de atenção que se quer preservar e ampliar ou como posições que se quer proteger ou atingir. Quando um indivíduo sente que outras pessoas estão "invadindo" seus interesses, cria defesas ou ataques para manter ou melhorar sua 
posição. O fluxo de política é intimamente ligado à maneira de a pessoa se posicionar. Uma forma de entender a política nas organizações é conceber o interesse em termos de três domínios inter-relacionados relativos a tarefa, carreira e vida pessoal. Existe uma tensão entre o trabalho de uma pessoa (tarefa), as aspirações de carreira e os valores pessoais e estilos de vida. Esses três domínios podem interagir e, frequentemente, o equilíbrio entre eles não é confortável; está sempre mudando e criando tensões, que são o centro da atividade política. Isso porque a área de completa convergência entre esses três interesses é geralmente pequena, o que faz com que a racionalidade organizacional seja um fenômeno tão raro. Os empregados trazem para o local de trabalho aspirações e visões sobre o que o futuro lhes reserva que constituem a base para os interesses de carreira. Trazem também suas personalidades, atitudes pessoais, crenças que representam os seus interesses pessoais, que determinam a maneira como eles agem em relação ao trabalho e à carreira. As tensões existentes entre os diferentes interesses tornam sua relação com o trabalho inerentemente política, mesmo antes de considerar a existência da ação de outros membros da organização. Essas tensões são intrínsecas à vida no trabalho por causa das contradições latentes entre as demandas do trabalho e do lazer, por um lado, e as demandas do presente e do futuro, por outro.

É possível observar que a política nas organizações está relacionada com a existência de interesses múltiplos e metas, muitas vezes, incompatíveis. A política nas organizações tem sido estudada em trabalhos clássicos relacionados à tomada de decisão estratégica, às teorias de dependência de recursos e à Teoria Institucional e, mais recentemente, tem sido objeto direto de pesquisas ligadas à percepção da política nas organizações e às competências políticas (LEPISTO; PRATT, 2012). A política nas organizações tem sido vista como um componente importante tanto de organizações do setor público quanto do privado. A própria definição de política organizacional permanece uma questão polêmica nos estudos organizacionais. A falta de consenso é um indicativo do debate permanente sobre o tema. $\mathrm{O}$ uso de diferentes termos considerados substituíveis, como competência política, tática de influência, gestão da impressão, comportamento político, manobras políticas, tem feito a pesquisa na área ficar fragmentada (VIGODA-GADOT; DORY, 2006; ULHA; JAFRI; DOST, 2011).

Deve-se salientar que apenas aceitar o comportamento político como uma característica da vida nas organizações não é suficiente para avaliar questões sobre sua eficiência e eficácia. É importante reconhecer que diferentes gestores são mais e outros menos efetivos no uso do comportamento político como consequência de suas 
habilidades. A eficiência e a eficácia do comportamento político dos gestores é uma área dos estudos da liderança ainda pouco explorada (SMITH et al., 2009). Bass e Bass (2008) alertam para a necessidade de uma perspectiva política da liderança mais equilibrada, já que os efeitos do comportamento político da liderança são quase sempre associados a efeitos negativos. Existe uma distinção na literatura quanto à política do dia a dia e o comportamento político extremo que viola as regras do "jogo". Alguns pesquisadores reconhecem que essa distinção e a possibilidade de uma visão positiva do comportamento político contribuam fortemente para o desenvolvimento de teorias políticas de liderança (HOUSE; ADITYA, 1997; BASS; BASS, 2008).

Apesar de, nas últimas décadas, ter havido muitas pesquisas e treinamentos de liderança, a prática nas organizações ainda apresenta muitas falhas quanto ao desenvolvimento e à atuação de suas lideranças. As organizações continuam a cometer um erro frequente ao escalar seus melhores profissionais técnicos para os cargos de liderança sem nenhum preparo ou mesmo vocação para o cargo. Segundo Dutra (2010), a carreira de gerente implica a atuação na "arena política" da organização. No entanto estudos mostram que, ao assumirem posições gerenciais, alguns profissionais técnicos recusaram-se a entrar na arena política, deixando de representar politicamente suas equipes na disputa por recursos. Uma das características principais da posição gerencial é a gestão de recursos escassos. Os recursos humanos, tecnológicos e financeiros são disputados entre pares, o que demanda uma grande articulação política. É sabido que nem todo bom profissional técnico ou funcional tem perfil para atuar na "arena política". Alguns profisssionais não valorizam a área, portanto têm dificuldade de desenvolverem-se nas atividades políticas. A consequência disso é que, na maioria das vezes, as empresas acabam perdendo bons técnicos e ganhando péssimos gestores. $\mathrm{O}$ ideal, segundo esse autor, é que as organizações criem condições para preparar e expor os funcionários a situações que exijam traquejo político, para, posteriormente, avaliar sua atuação, sua adequação à experiência e seu gosto pela atividade.

Um estudo realizado pelo Center for Creative Leadership apontou que a razão mais proeminente de insucesso na carreira dos gestores é a falta de habilidade social e interpessoal (VAN VELSOR; LESLIE, 1995). O líder que reconhece a realidade política e participa rotineiramente do espaço político proporciona a facilitação da performance e as oportunidades de crescimento na carreira dos seus liderados (HOCHWARTER, 2012). 
Para Mintzberg (1975), nenhum trabalho é mais vital para a nossa sociedade do que a função de gestor. É a tarefa de gestor que determina se o trabalho das instituições sociais servirá bem ou não à sociedade, se está havendo desperdício ou não de recursos e talentos. Todavia é preciso se livrar do folclore que cerca a função dos gestores e tratar de maneira realista o seu papel para que seja possível promover avanços reais quanto à sua performance. O citado autor faz uma descrição detalhada do trabalho de gestor e sugere um número importante de competências que esse gestor deve apresentar, como o desenvolvimento de relacionamento com os pares, a capacidade de promover negociações, de envolver os subordinados, de resolver conflitos, de tomar decisão em condições de ambiguidade extrema, de alocar recursos e de estabelecer redes de relacionamento para obtenção de informação, subsequentemente disseminando essas informações. Ainda segundo esse autor, se os gestores desejam ser mais efetivos, devem reconhecer qual é realmente o seu papel e então usar os recursos a sua disposição para apoiar e não prejudicar a natureza do seu próprio trabalho.

Apesar da importância do papel político na função dos gestores, a ênfase no aspecto negativo do comportamento político tem sido uma falha nos estudos sobre esse tema, a tal ponto que se ignoram os aspectos funcionais e positivos do comportamento político para os indivíduos, os grupos e as organizações. Vários pesquisadores consideram a política nas organizações como mais próxima a um conceito neutro. A natureza positiva ou negativa do comportamento pode ser vista em razão da atribuição da intenção dos seus atores ou aos resultados pessoais e organizacionais associados a ele (DAVID; GARDNER, 2004; FERRIS et al., 2002; FEDOR et al., 2008).

Muitas definições de política incluem palavras e expressões como "ilegitimidade" e "não sancionados", o que enfatiza a conotação negativa da política e afasta a realidade de que ela pode ser utilizada para propósitos legítimos. Pesquisadores, recentemente, têm apoiado os estudos positivos da política, considerando-a como uma prática necessária ao invés de algo demoníaco (FERRIS; TREADWAY, 2012). Em razão disso, começam a surgir pesquisas que buscam compreender as possibilidades positivas da política nas organizações, como os estudos de Ferris e Treadway (2012) e de Ferris et al. (2012), que integram os processos políticos ao alcance de metas individuais e organizacionais, aos resultados dos seguidores e à efetividade da liderança.

Para Buchanan e Badham (1999), os profissionais que insistirem que o comportamento político é, invariavelmente, prejudicial e deve ser erradicado não conseguirão progredir no contexto organizacional. E aqueles que creem que o 
envolvimento na trama política é pouco razoável tornarão a experiência de liderar bastante frustrante, colhendo apenas o descontentamento, o cinismo, a insatisfação e a desmotivação dos seus colaboradores e, consequentemente, comprometerão os resultados organizacionais.

Mudanças largamente difundidas no ambiente organizacional sugerem que as competências sociais estão se tornando mais importantes. Pesquisadores acreditam que as organizações atualmente se baseiam cada vez menos nas estruturas hierárquicas e burocráticas e que novas teorias e construtos são necessários para refletir essa transformação no design das organizações (DAFT; LEWIN, 1993; STEWART; CARSON, 1997).

Nesse sentido, as organizações têm sido compelidas a desenvolver maior capacidade adaptativa para atender às exigências desses novos tempos, assim como buscar elementos de inovação e de diferenciação que lhes assegurem a sobrevivência e uma competitividade sustentável. No atual estágio de desenvolvimento, os métodos de produção se sofisticam, exigindo maior flexibilidade e dispositivos de regulação que envolvam a mobilização de subjetividades e competências cada vez mais amplas e intrínsecas ao que há de mais humano, como a criatividade, a paixão, a emoção, a integridade e o comprometimento. Atualmente, o que se constata é uma preocupação crescente das organizações em ampliar o escopo de conhecimentos, habilidades e atitudes de seus gestores. As organizações têm buscado promover a inclusão do desenvolvimento de competências em liderança, tanto nos seus níveis estratégico e tático quanto no operacional (SANT'ANNA, 2010).

O estilo ou a execução de um comportamento de influência que representa um tipo especial de competência social e astúcia social entendidas como competência política é uma parte crítica e pouco explorada na literatura organizacional. As pesquisas sobre a perspectiva política nas organizações têm fortes raízes nas teorias e pesquisas sobre influência social. No entanto, até há pouco tempo, o estilo utilizado no exercício da influência, que explicava o sucesso do esforço para conseguir exercê-la, não utilizava essa base teórica (JONES, 1990). Essa peça que faltava foi fornecida pelo construto “competência política". Indivíduos com competências políticas são capazes de diagnosticar precisamente o contexto social e, a partir de então, adaptar seu comportamento à situação, por meio da seleção dos métodos e táticas apropriadas para influenciar o comportamento de outros (FERRIS; TREADWAY, 2012). 
A expressão "competência política" é proveniente do termo em inglês Political Skill, cuja tradução literal para o português é "habilidade política". No entanto, após o estudo mais detalhado do construto, optou-se por traduzi-lo para "competência política", uma vez que não há prejuízo em seu significado. Pelo contrário, essa denominação mostra-se mais adequada às teorias e aos conceitos que envolvem o construto. As razões que motivaram a autora deste trabalho a se definir por essa denominação serão explicitadas a seguir. A primeira explicação refere-se ao fato de o termo "competência" ser mais amplo do que habilidade, por aquele estar relacionado a conhecimentos, habilidades e atitudes. A competência política é um construto complexo composto por quatro dimensões críticas: astúcia social, influência interpessoal, habilidade de network e sinceridade evidente. Essas dimensões tratam de conhecimentos e habilidades que geram o aumento do poder de influência pessoal e da efetividade social. Segundo Mintzberg (1983), a habilidade política deve ser precedida da vontade política, que é a motivação para se engajar no comportamento político, ou seja, na vontade para utilizar esses conhecimentos e habilidades para transformá-los em atitude. O construto engloba, portanto, as três dimensões essenciais (conhecimento, habilidades e atitudes) ao conceito de competência. Outro motivo para adoção do termo "competência" se relaciona à conotação positiva dessa palavra, que é automaticamente associada à efetividade, e à sua associação ao ambiente organizacional. A competência política, segundo os principais autores que tratam desse tema, é uma competência necessária para alcançar a efetividade no contexto organizacional. Portanto, na presente pesquisa, a expressão "competência política" será utilizada em razão da maior aderência aos conceitos e perspectivas utilizados neste estudo.

O desenvolvimento das competências políticas é considerado potencialmente uma nova área de interesse na academia. Esses estudos estão relacionados ao movimento dos programas de desenvolvimento de lideranças e às decisões de seleção e promoção. Nos últimos anos, muitas pesquisas têm sido realizadas sobre as tendências e desafios da área de Recursos Humanos e mostram a relevância do tema desenvolvimento de lideranças. Dados levantados pela Society for Human Resources Management (SHRM), a maior sociedade de Gestão de Recursos Humanos do mundo, mostraram que o desenvolvimento de lideranças está na segunda posição na preocupação dos profissionais da área (SHRM, 2013). Além disso, o Programa de Estudos em Gestão de Pessoas da Fundação Instituto de Administração/parceria Universidade de São Paulo (Progep/FIA) apresentou, em 2011, os resultados da 
pesquisa Delphi RH 2010 (FISCHER; ALBUQUERQUE, 2001), que aponta, em primeiro lugar na lista das estratégias de gestão de pessoas para o ano de 2015, a necessidade de maior investimento em capacitação e desenvolvimento dos gestores/lideranças no Brasil, o que demonstra a relevância do tema no âmbito nacional e internacional.

A literatura internacional sobre a perspectiva política da liderança é ainda escassa e muito recente. Em 2004, uma edição especial do The Leadership Quarterly abordou a perspectiva política na liderança e fez uma chamada em um artigo para a importância de estudos sobre o tema. O artigo mostra que, apesar da comprovada natureza política das organizações e da liderança, muitas questões encontram-se sem resposta e ainda estão em seu estágio inicial de pesquisa, sendo uma área potencialmente importante e interessante para as pesquisas de liderança (HOUSE; ADITYA, 1997). Apesar da chamada e do aumento de pesquisas nos últimos dez anos, ainda são poucas as pesquisas que exploram o tema, cujo desenvolvimento ainda ocorre lentamente e é marcado por alguns poucos modelos e paradigmas dominantes. Acreditase que uma abordagem mais neutra sobre as atividades políticas pode levar a modelos mais ecléticos, refletindo, dessa forma, o caráter potencial dos estudos que podem levar a saltos relevantes na teoria, pesquisas e práticas da liderança (FERRIS; TREADWAY, 2012).

No Brasil, as pesquisas sobre o comportamento político da liderança e competências políticas são praticamente inexistentes, conforme atestou o levantamento de pesquisas publicadas no período de 2010 a 2016 nos principais periódicos do país. Foram analisados os anais dos Encontros promovidos pela Associação Nacional de PósGraduação e Pesquisa em Administração (EnANPAD), especificamente as divisões acadêmicas de Gestão de Pessoas e Relações de Trabalho (GPR) e Estudos Organizacionais (EOR), e as principais revistas nacionais (RAE, RAE-E, RAC, RAC-E, RAUSP, BAR E RAM). Não foi encontrado nenhum trabalho relativo à persperctiva política da liderança nem sobre o construto "competência política da liderança".

No processo de levantamento dos textos, realizou-se a verificação dos títulos dos artigos e, nos casos em que o assunto apresentava possível correlação com o tema, foi feita a leitura do resumo para verificação. Nesse procedimento, foram encontrados artigos relacionados à justiça, ao suporte organizacional, às relações de poder e apenas dois artigos sobre comportamento político, que foram publicados no EnANPAD (EOR) 2010 e RAM 2011, pelos mesmos autores, Mansur e Sobral (2010, 2011). Esses dois 
artigos avaliaram o comportamento político no contexto cultural brasileiro relacionado ao comportamento negligente, a intenções de saída e desempenho nas organizações, mediados pelo nível de satisfação. Esses autores consideram o comportamento político necessariamente ligado à obtenção de benefícios em prol do autointeresse. Os resultados mostraram que o traço cultural brasileiro do "jeitinho" foi associado ao comportamento político para obtenção do benefício próprio e praticado por todos, indepedentemente da posição hierárquica e da detenção de poder. Eles concluiram que o "jeitinho" parece traduzir a existência da política como inerente às organizações brasileiras. $\mathrm{O}$ trabalho apresenta limitações em relação ao tamanho e à distribuição da amostra, autorrelato e possível viés de desejabilidade.

Além do período pesquisado, durante o levantamento do referencial teórico, encontrou-se um artigo publicado na Academy of Management em 2004 (PERREWÉ et al., 2004), cuja pesquisa foi aplicada em profissionais, com papel de supervisão ou não, em três grandes empresas de óleo no Brasil. O trabalho avaliou o efeito neutralizador da competência política no estresse e na tensão no trabalho nos casos de conflito de papéis. Os resultados apoiam a visão de que a competência política serve como um antídoto das consequências disfuncionais do estresse, isso porque ela proporciona um sentimento de adequação da pessoa ao seu ambiente, maior flexibilidade e habilidade de enfrentamento. A escala utilizada para avaliar a competência política foi uma escala inicial de seis itens que estava em desenvolvimento por Ferris et al.(1999). Nesse trabalho, utilizamos a escala consolidada de 18 itens elaborada por Ferris et al. (2005). Esse levantamento mostra a inexistência de estudos sobre a perspectiva política da liderança e de trabalhos que abordem o construto "competências políticas da liderança no cenário nacional", o que comprova a originalidade do tema.

Para Pfeffer (1981), é evidente que os resultados de uma organização dependem diretamente do modo como os atores organizacionais se posicionam no campo do poder e da política, fato que constitui razão mais do que suficiente para que os líderes se interessem por essas questões, procurem compreender o seu enredo e se coloquem devidamente nesse terreno. Se isso não acontecer, os líderes organizacionais correm o risco de usar o poder e a política quando não é necessário, violando normas de comportamento, desperdiçando recursos ou subestimando o grau em que esses mecanismos necessitam ser empregados. Para Buchanan e Badham (1999), se se manifesta inabilidade em aceitar e compreender a organização como um território eminentemente político, está-se, na verdade, ignorando as especificidades da 
organização pós-moderna. A fluidez, a mudança, a incerteza, a ambiguidade e a descontinuidade que são inerentes a esse ambiente fazem despontar novas relações de poder, sendo que os profissionais competem arduamente pelo seu espaço nesse território.

Segundo Crozier e Friedberg (1980), o aparecimento da organização política não ocorre apenas em razão das limitações provenientes das imperfeições do conhecimento e da informação, mas, principalmente, por um fenômeno ligado às representações e às capacidades cognitivas. Isso porque cada profissional enxerga a organização sob o ângulo dos seus objetivos; cada pessoa tem um campo de competência particular e conhecimentos limitados por esse campo. Todos defendem o seu domínio, e todos o fazem quanto maiores forem as suas convicções.

A competência política é vista como fator crítico para a efetividade e o desenvolvimento da carreira de lideranças (FERRIS et al., 2000). Para Farrell e Petersen (1982), o sucesso da gestão das atividades políticas é igualmente necessário para alcançar a efetividade organizacional. Em alguns casos, as atividades políticas são précondição para um comportamento administrativo racional. Esses autores acreditam que a efetiva utilização das competências políticas torna-se cada vez mais importante para a carreira dos gestores. Indivíduos politicamente hábeis conseguem criar sinergia através de um comportamento distinto que transcende a simples soma das partes para alcançar um conjunto de dinâmicas interpessoais e o sucesso pessoal e profissional (FERRIS et al., 2000).

A competência política tem sido relacionada a resultados como sucesso na carreira (BLICKLE et al., 2011a; WEI et al., 2012; KIMURA, 2014). Nesta pesquisa trabalhou-se com a ideia de desenvolvimento na carreira, ao invés de sucesso na carreira, uma vez que o sucesso é uma grandeza subjetiva, relacionada aos valores de cada indivíduo. A competência política tem sido crescentemente reconhecida como uma competência crítica, essencial para o trabalho nas organizações, uma vez que pessoas com competências políticas tendem a ser selecionadas nas entrevistas como mais adequadas e apresentam boa performance no trabalho. No entanto essa competência precisa ser incorporada em um repertório mais amplo das competências-chave e ser incluída nos estudos e na educação dos Recursos Humanos (FERRIS et al., 2005).

Neste estudo, tem-se o objetivo de aprofundar o conhecimento sobre a competência política que se acredita ser uma competência fundamental para que as lideranças possam atuar no contexto organizacional, já que a competência política é 
caracterizada por um padrão de competência social que reflete a manifestação de um comportamento cognitivo e afetivo que demonstra efeitos tanto na própria pessoa como nos outros. Essa competência é considerada essencial para a efetividade no trabalho e na maneira bem sucedida de lidar com a realidade política das organizações (FERRIS et al., 2007).

Considerando a escassez de pesquisas focadas diretamente na política e nos seus aspectos positivos, esta pesquisa busca preencher parte dessa lacuna ao trabalhar a perspectiva política nas organizações, com ênfase nos seus aspectos positivos relacionados aos sistemas de carreira e liderança. Ao considerar a carreira como níveis de complexidade crescentes, a atuação na "arena política" passa a representar um nível de complexidade maior para o profissional que anteriormente atuava apenas na área técnica. Atuar nessa "arena política" é uma parte importante na carreira dos gestores, apesar disso esta temática é, ainda, pouco explorada. Neste trabalho, pondera-se o conceito neutro de política e enfatizam-se seus aspectos positivos. A busca por explorar a perspectiva positiva do comportamento político ocorre em razão da importância de uma visão mais balanceada sobre o tema. $\mathrm{O}$ foco nos aspectos funcionais do comportamento político se dá pela busca de maior compreensão do construto "competência política", por se acreditar ser essa uma competência fundamental para as lideranças no ambiente atual das organizações. Para tanto, pretende-se observar as possíveis contribuições da competência política no desenvolvimento da carreira, na reputação e atribuição de legitimidade da liderança. No entanto é importante ressaltar que evidenciar os aspectos positivos não significa negar a realidade de que os comportamentos políticos possam ser utilizados também de maneiras disfuncionais. Pretende-se, ainda, mostrar como esse tema é visto pelas organizações e gestores brasileiros.

\subsection{Justificativa}

$\mathrm{O}$ ambiente mais competitivo impõe às empresas a necessidade de um desenvolvimento constante. Esse desenvolvimento está atrelado à capacidade de contribuição das pessoas que trabalham na organização. Mesmo que implicitamente, a valorização dos profissionais por meio de aumentos salariais, promoções e conquista política é a forma de manifestação e reconhecimento pelo aumento dessa contribuição 
(DUTRA, 2010). As organizações enfrentam o desafio de manter pessoas talentosas que sejam capazes de assumir posições estratégicas na hierarquia organizacional (QUEIROZ; LEITE, 2010). Para Charan, Drotter e Noel (2010), as organizações devem desenvolver e manter líderes hábeis e preparados nos vários níveis de liderança dentro da empresa, já que os diferentes níveis de liderança constituem trilhas de desenvolvimento. Para que os gestores sejam bem-sucedidos, eles têm que atuar politicamente ao menos em parte do tempo (BUCHANAN, 2008).

Se, por um lado, as empresas reconhecem a contribuição das pessoas para sua sobrevivência e sucesso no mercado, por outro, criou-se, a partir de sua ideologia gerencialista, estilos de vida, modos de existência ou modos de subjetivação contemporâneos nas diversas esferas sociais, a partir dos modos de gestão vigentes. A gestão gerencialista é uma ideologia que traduz as atividades humanas em indicadores de desempenhos, e esses desempenhos são avaliados em termos de custos ou benefícios. É construída uma representação do humano como um recurso a serviço da empresa, contribuindo, assim, para sua instrumentalização. O foco direto dessa gestão em eficiência e eficácia promove a gestão de si, que deve contemplar um estilo normatizado, claramente compreendido por meio de códigos de conduta que identificam aqueles que se empenham em merecer a denominação de executivos. Os executivos, atraídos pelo estilo de vida glamourizado, submetem-se às condições impostas que, muitas vezes, mascaram as mais diversas situações de pressão, cobranças e cargas excessivas do trabalho. A palavra executivo, para muitos, tornou-se a senha para entrar no mundo prometido dos mercados e da prosperidade (GAULEJAC, 2007).

A carreira de gestão ainda é, em muitas organizações, a única alternativa de desenvolvimento real dentro da empresa. Por isso, tanto a empresa quanto os profissionais acabam vendo os cargos de gestão como uma premiação ou como a única trajetória possível. A consequência disso é que, em muitos casos, pessoas sem vocação ou vontade para atuar em cargos de gestão acabam assumindo tais cargos, em razão de um desejo de crescimento e ascensão profissional. O resultado disso é que, na maioria das vezes, as empresas acabam perdendo bons técnicos e ganhando péssimos gestores. Isso porque, segundo Dutra (2010), a transição de uma carreira técnica para uma carreira gerencial nem sempre é interpretada pelas organizações como migração de carreiras de naturezas diferentes. Essa migração exige muita preparação da empresa e de seus profissionais e, se for feita de forma inadequada, pode acabar gerando uma insatisfação das partes envolvidas nesse processo. Esse autor alerta ainda para o fato de 
que a carreira de gerente implica a atuação na "arena política" da organização, mas que nem todo bom profissional técnico ou funcional tem perfil para atuar nesse espaço. Alguns profissionais não valorizam a área e, portanto, têm dificuldade de desenvolverem-se nas atividades políticas (DUTRA, 2010). A consequência disso é a inadequação e insatisfação dos profissionais e também da empresa.

A busca por um estilo de vida e carreira alicerçada na ideologia gerencialista e a falta de uma opção de trajetória de carreira adequada aos perfis técnicos, muitas vezes, pode gerar prejuízos financeiros, psicológicos e sociais para os profissionais e para a organização. A compreensão da demanda política nos cargos de gestão pode ajudar a área estratégica de gestão de pessoas a selecionar e desenvolver os seus gestores, levando em consideração a perspectiva política na carreira das lideranças.

No cenário atual, gestores e funcionários já não exercem tarefas individuais ou atividades isoladas de outros. Pelo contrário, as atividades são coordenadas em grupos e a comunicação é direta com clientes e consumidores. As habilidades gerenciais que refletem negociação, coordenação e facilitação passaram a ser mais valorizadas. Essas habilidades são requeridas de trabalhadores em todos os níveis hierárquicos e requerem o desenvolvimento de habilidades sociais e interpessoais. A competência política se diferencia de outras habilidades sociais por tratar de interações específicas para o alcance do sucesso organizacional. Nesse contexto, o papel do gestor muda de um monitoramento direto e imediato para um controle envolvendo coaching e facilitador do esforço do grupo (FERRIS et al., 2000).

Yulk (1999) elaborou um artigo sobre as fraquezas conceituais nas teorias das lideranças, com enfoque nas lideranças transformacional e carismática. A fraqueza conceitual encontrada foi similar à das teorias iniciais sobre liderança, o que inclui construtos ambíguos, descrição insuficiente dos processos, um foco restrito no processo diádico, omissão de alguns comportamentos relevantes, especificações insuficientes das condições limitadas (variáveis situacionais) e uma tendência ao conceito heroico de liderança. A teoria também apresenta uma omissão que envolve a interação do líder com seus superiores, seus pares e pessoas externas à organização, cuja informação, cooperação e apoio político são essenciais para a performance do grupo em sua missão. Apesar das críticas levantadas por Yulk em 1999, poucos avanços foram realizados para compreender como ocorrem as relações políticas nas organizações, especificamente a relação da liderança com pares e superiores na arena política, e qual a influência desses agentes na reputação e atribuição de legitimidade do líder. 
Para Pfeffer (1992), o poder pode ser exercido por razões positivas, assim como negativas. Alguns pesquisadores defendem que os conflitos internos existentes entre grupos de diferentes interesses são vitais para a inovação e o sucesso das organizações. Os indivíduos alcançam seus objetivos e metas por meio de sua habilidade de influenciar não apenas pessoas, mas, mais importante, uma coalizão de pessoas. Por meio do alinhamento de interesses de grupos, as coalizões são capazes de ganhar um poder relativo e, por meio dele, afetar a organização como um todo. $\mathrm{O}$ conflito nas organizações faz com que o interesse da coalizão mais poderosa seja atendido em detrimento do interesse de outros membros da organização (BACHARACH; LAWLER, 1980; FERRIS; TREADWAY, 2012). Na atualidade, a inovação é um tema obrigatório para as empresas que querem garantir sua sobrevivência no presente e futuro. Ao considerar que os conflitos internos são vitais para a inovação, que as competências políticas podem contribuir para a criação de coalizões e que estas, através da sua força, podem alcançar inovações relevantes, é possível afirmar que o estudo do comportamento político nas organizações pode contribuir também para o tema da inovação nas organizações.

Outro ponto importante nos estudos organizacionais, em especial quanto ao tema da liderança, é a inovação na gestão, que trata, normalmente, da redistribuição do poder nas organizações. Segundo Hamel e Breen (2007), um gestor de pensamento tradicional fica, compreensivelmente, desconcertado quando confrontado com a realidade de uma empresa onde o poder está desligado do cargo, onde não se podem aprovar decisões só por estar mais alto no organograma, onde o poder desaparece rapidamente se ninguém estiver disposto a segui-lo e onde as credenciais e superioridade intelectual não são garantia de reconhecimento. As mudanças e inovações na forma de gerir as organizações têm alterado os valores e as regras nas organizações. O poder nas organizações, na atualidade, está desligado do organograma, as decisões são colegiadas e ganha poder quem consegue mais apoio (HAMEL; BREEN, 2007). Nesse cenário de mudanças na gestão das organizações, a competência política das lideranças passa a ter um papel relevante pela sua característica de influência na criação de coalizões e na mobilização de pessoas. Essa realidade mostra o enfraquecimento do sistema de influência de autoridade e a ascensão do sistema de influência político, que é o sistema em que as “diferentes vozes são ouvidas” (MINTZBERG, 1985).

A busca constante pela vantagem competitiva e bons resultados alterou o pensamento contemporâneo sobre performance no trabalho. As organizações passaram a 
se preocupar com duas categorias de performance: 1) a performance de tarefas, que está relacionada aos elementos tradicionais descritos pela função e 2) a performance contextual, que corresponde à estrutura social da organização. Atualmente, a performance contextual tem sido mais valorizada pelas empresas por lidar com uma variedade de aspectos da performance, como motivação, relações interpessoais e sociais. Nessa categoria de performance, o componente principal é a efetividade interpessoal ou a extensão em que uma pessoa consegue manter boa relação com superiores, colegas de trabalho e outros da organização (FERRIS et al., 2005). Entretanto as duas categorias podem ser avaliadas por mensurações distintas: a performance por tarefa pela inteligência e habilidade cognitiva e a performance contextual pela efetividade social e a personalidade (BORMAN et al., 2003). A competência política, por ser um construto relacionado à efetividade social, está relacionada à performance contextual, que representa a preocupação atual das organizações.

Para Bourdieu (1989), o jogo do poder merece ser jogado, seja para a conservação, seja para a subversão da ordem. No entanto o autor ressalta que falar sobre poder, questionar como o poder é mobilizado por entre as estruturas organizacionais não agrada àqueles que analisam as organizações. Ainda sobre a noção do desconforto que a política e o uso do poder causam, Pfeffer (1992) argumenta que empregar o poder de forma estratégica ou propositada é normalmente evitada ou mal vista pela maioria das pessoas. Isso porque, embora os indivíduos em geral possam ter escrúpulos, sempre haverá aqueles que não têm. Para esse autor, conhecimento sem poder é inútil e o poder sem habilidade para empregá-lo efetivamente é um desperdiço. A compreensão da dinâmica do poder sem ter a vontade de utilizar tal conhecimento é um grande desperdício. Pfeffer (1992) afirma que não é evidente que ignorar a realidade social do poder e da influência pode fazê-lo desaparecer ou que construir estruturas sociais mais simples e menos interdependentes faz com que as organizações sejam mais efetivas e tenham maior capacidade de sobrevivência. Portanto realizar tal estudo se justifica em razão de ser este um tema importante, que, no entanto, é pouco explorado e até mesmo evitado pelos estudiosos organizacionais. 


\subsection{Objetivos}

\subsubsection{Objetivo geral}

Esta pesquisa visa analisar a competência política, sua relação com o desenvolvimento da carreira dos gestores, o aumento da reputação e a atribuição de legitimidade das lideranças no contexto nacional. Para tanto, questões foram elaboradas com o objetivo de compreender como as organizações e os gestores brasileiros percebem o ambiente político e como eles se sentem em relação ao aspecto político da função de gestor. Pretende-se ainda verificar se a competência política é reconhecida como uma competência importante e positiva para os gestores, se as lideranças brasileiras se consideram politicamente competentes e se elas são consideradas politicamente competentes por seus superiores ou profissionais de RH. Outro ponto a ser verificado é se as lideranças com boa reputação e as lideranças consideradas legítimas têm características que possam ser associadas às características de uma liderança politicamente competente. Para tanto, elaboraram-se os objetivos específicos deste estudo.

\subsubsection{Objetivos específicos}

A convivência humana é marcada por uma distribuição de papéis, por expectativas mútuas e por um sistema de legitimidade, de direitos e deveres recíprocos (ELIAS, 1997). A ocupação de um cargo de liderança, por si só, não é suficiente para legitimá-la. O processo de legitimação envolve uma série de questões, relações, mérito e políticas. Nesse sentido, legitimidade e mérito se articulam na avaliação da ação da liderança, já que, ao desempenhar esse papel, quem avalia o desempenho e estabelece a autenticidade da posição social são os próprios sujeitos da ação, bem como todos os outros nela implicados (por exemplo: pares, subordinados, superiores hierárquicos e profissionais de Recursos Humanos). Eles constituem o próprio aparelho legitimador, que conta ainda com símbolos, rituais e cerimônias para a transmissão dos valores que postulam que posições sociais serão resultantes do mérito de cada um (VIEIRA; PEREIRA; ROSCOE, 2010).

Líderes efetivos incentivam a coesão de grupos e a adaptação em ambientes competitivos e hostis e convencem os subordinados a temporariamente abandonar seus 
interesses individuais para perseguir uma meta compartilhada comum ao grupo. Apesar de as metas dos líderes serem bem definidas, a maneira de atingi-las pode variar bastante, assim como suas motivações e valores. A Teoria Socioanalítica defende que os motivos dos líderes representa uma questão chave para a compreensão da motivação e do comportamento. Especificamente, os motivos determinam como serão as interações, o desejo ou não de entrar nas relações e como as pessoas atuarão em seus papéis (HOGAN; KAISER, 2005; HOGAN; BLICKLE, 2013).

Mintzberg $(1983,1985)$ definiu as organizações como arenas políticas e sugeriu que, para efetividade nesse contexto, são necessárias vontade e habilidade política. A vontade política pode ser considerada um requisito para atuação no espaço político. É a motivação para adotar comportamentos para alcançar os objetivos, que, no entanto, podem pôr em risco o capital relacional e reputacional do seu agente. Já a habilidade política é a capacidade de entender os outros efetivamente e utilizar esse conhecimento para influenciá-los a agirem de forma a aprimorar os objetivos pessoais e organizacionais (FERRIS et al., 2005). A competência política é vista como fator crítico para a efetividade e desenvolvimento da carreira de lideranças (FERRIS et al., 2000). A competência política proporciona ao líder a competência que pode contribuir para os resultados organizacionais. Esta pesquisa tem como primeiro objetivo específico identificar se as lideranças brasileiras consideram-se politicamente competentes e se são percebidas da mesma forma por seus pares, superiores e diretores de RH.

Muitos autores concordam que o ambiente organizacional é, inerentemente, uma arena política (MINTZBERG, 1983; PFEFFER, 1981; FERRIS et al., 2000; JUDGE; BRETZ,1994). No entanto, a maioria das pesquisas e teorias sobre política organizacional enfoca predominantemente os aspectos negativos e disfuncionais do comportamento político. Neste estudo, adotou-se um conceito neutro de política. Para Ferris e Treadway (2012), a adoção de um conceito neutro que elimine uma definição carregada de valores pode resultar em uma distinção do comportamento político como um conjunto de características que não sejam exclusivamente positivas ou negativas, ampliando o construto de política nas organizações (FERRIS; TREADWAY, 2012). Bass e Bass (2008) alertam para o fato de que os efeitos do comportamento político da liderança são quase sempre associados a efeitos negativos, portanto há a necessidade de uma perspectiva política da liderança mais equilibrada. Alguns autores defendem que os líderes podem se comportar politicamente com esforços para beneficiar a organização e seus liderados. Neste estudo, deu-se ênfase à perspectiva positiva do comportamento 
político, por meio do construto "competência política". Para tanto, gestores foram questionados sobre o ambiente político das organizações, assim como o aspecto político da função do gestor. Pediu-se a eles, ainda, que fossem apontados comportamentos que pudessem ser identificados como funcionais e disfuncionais e maneiras para incentivar o comportamento político funcional e inibir o comportamento político disfuncional. Com isso, buscou-se atingir o segundo objetivo específico desta pesquisa, qual seja, verificar se os aspectos positivos do ambiente político nas organizações e da função política do gestor são percebidos pelas organizações e profissionais brasileiros.

É sabido que a autoridade formal das lideranças, por si só, não lhes garante suporte em suas decisões. A legitimidade de um líder é baseada na sua competência, na sua habilidade e no seu comprometimento para alcançar as metas do grupo (HOCHWARTER, 2012). A legitimidade de um líder refere-se ao nível em que outros acreditam que ele mereça gerir, ordenar e demandar suas ações e exercer influência. Da mesma forma, a reputação individual é um construto mais sociopolítico do que científico. A reputação de um líder é um produto e é também definida por suas relações sociais. Os indivíduos podem desenvolver sua reputação no trabalho, principalmente em razão da sua capacidade de ter uma boa performance, por ser colaborativo e por ajudar os outros. Considerando isso, buscou-se caracterizar líderes com uma boa reputação e líderes considerados legítimos, para então, por meio da associação dessa caracterização com a competência política, avaliar se a competencia política pode contribui para o aumento da reputação e atribuição de legitimidade da liderança, o que constitui o terceiro objetivo específico desta pesquisa.

Outro aspecto que se almejou avaliar no presente estudo está relacionado ao papel da competência política no desenvolvimento da carreira das lideranças. O processo de desenvolvimento e promoção de lideranças é complexo e envolve não apenas as questões técnicas, mas também disputa por controle e poder entre pares, seleção e preparação de um sucessor, influências institucionais e do ambiente externo, contratos psicológicos, entre outros aspectos. Esse contexto, certamente, exige articulação política e competências políticas (JUDGE; BRETZ, 1994). Após a caracterização pelos entrevistados dos profissionais competentes politicamente, do papel da competência política na própria carreira e da avaliação dessas características no processo de contratação e promoção de profissionais para suas equipes, buscou-se, como o quarto objetivo específico desta pesquisa, verificar se as organizações 
brasileiras e seus profissionais reconhecem a importância da competência política no desenvolvimento da carreira dos seus gestores. 


\section{REFERENCIAL TEÓRICO}

Muitos autores concordam que as diferenças individuais afetam a aquisição de poder nas organizações, principalmente a personalidade e as características individuais. A maioria dos pesquisadores se dedicou a compreender os resultados do poder, portanto a questão sobre como os indivíduos adquirem poder é menos comum na literatura sobre o tema. Para Pfeffer (2010a, 2010b), o poder reflete o exercício da influência sobre os outros, e a competência política proporciona a experiência e o conjunto de habilidades para influenciar e adquirir recursos, como a performance, de maneira que esses recursos possam se transformar em avaliações positivas de poder pelos outros. Para Mintzberg (1983), os indivíduos precisam de vontade e habilidade política para adquirir poder na organização. De acordo com Krackhardt (1990), indivíduos com grande conhecimento e astúcia em relação ao contexto social e relacional tendem a ser os mais poderosos, e os indivíduos poderosos geralmente possuem grandes habilidades relacionais e de comunicação para construir relacionamentos. Na presente pesquisa, tratou-se da perspectiva política das organizações, especificamente na carreira das lideranças, por meio do construto "competência política". Trabalhou-se com a premissa de que a competência política, por ser um construto de efetividade social, contribui para o aumento da reputação e atribuição de legitimidade e, como consequência, leva à aquisição de poder. Portanto julga-se necessária uma discussão, mesmo que breve, sobre a relação entre os construtos poder, política e influência.

Os temas poder e política sempre foram objeto de estudos e de interesse desde o início da humanidade. Platão, Aristóteles, Rousseau, Maquiavel, Weber e, mais recentemente, Arendt e Foucault são alguns dos nomes dos grandes estudiosos que se dedicaram em profundidade à compreensão desses construtos. No entanto, optou-se por não aprofundar as discussões sobre esses temas, mesmo que, inevitavelmente, este trabalho tenha sido influenciado de alguma maneira e em certo grau por eles, principalmente pelo fato de esses estudos, na sua maioria, problematizarem as relações de poder e política em um contexto de governança pública. É o caso, por exemplo, da República, de Platão (2000), que trata da gestão das cidades gregas. Essa delimitação é importante, no sentido de ressaltar a relevância do conhecimento acumulado a respeito do tema (estudos anteriores e seminais), já que o objetivo desta pesquisa é avaliar o poder, a política e a influência na prática das organizações, em especial das organizações privadas, considerando a conjuntura atual, em que as dinâmicas de 
mercado, a competição, as mudanças constantes e a inovação se intensificam. Essas observações têm o intuito de salientar o enfoque desta pesquisa, que trata do ambiente organizacional circunscrito à realidade atual e com o olhar voltado para as perspectivas futuras.

\subsection{Poder, política e influência}

Poder, política e influência são termos associados, uma vez que o poder é a habilidade de influenciar comportamentos, mudar o curso dos acontecimentos, superar a resistência e a capacidade de fazer com que as pessoas realizem coisas que não fariam. Já a política é definida como o processo, as ações e comportamentos nos quais esse poder potencial é utilizado (PFEFFER, 1992). Tanto o uso do poder quanto o ganho de conformidade via influência são importantes para a conceituação de política nas organizações (LEPISTO; PRATT, 2012).

Muitos estudos importantes foram realizados sobre a aquisição de poder no ambiente organizacional. As pesquisas iniciais sobre o tema tiveram uma natureza sociológica, com o foco em explicações relacionadas a questões estruturais e posição/cargos na empresa. No entanto, é sabido que o poder não reside apenas nas relações hierárquicas formais consideradas legítimas; ele habita também as relações informais, em que a expertise, o carisma, a benevolência e a afeição afetam a aquisição de poder. $\mathrm{O}$ poder permeia as interações sociais permanentemente e o conhecimento imperfeito que acabam tecendo a vida social no ambiente organizacional (PFEFFER, 1992).

As organizações, independentemente do seu tamanho ou complexidade, constituem palcos onde ocorrem jogos de poder e conflitos derivados de interesses divergentes, que manipulam indivíduos, grupos e coalizões. $\mathrm{Na}$ sociedade contemporânea, as organizações estão presentes em todas as esferas da vida social, ao influir no ambiente econômico, nas disputas políticas e ideológicas que são travadas no espaço social, nas dimensões culturais e religiosas que estruturam cada tempo e espaço. Na sociedade industrial, as bases da autoridade encontravam-se na supremacia da razão e no contrato social. A vitória da burocracia sobre as formas de organização social anteriores foi determinada pela superioridade técnica, pelos princípios da meritocracia e pela previsibilidade da atividade econômica. A racionalização e a disciplina compõem os elementos fundamentais para o sistema capitalista. Se, por um lado, para alguns 
autores clássicos, o processo de burocratização representou a marcha inexorável da sociedade humana em direção a um futuro de submissão e de racionalização extrema, por outro lado, essa visão pessimista deu lugar a enfoques como o de Arhne (1990), que rejeitam o caráter de inevitabilidade e determinismo histórico, dando ênfase aos conceitos de hegemonia e de tendências dominantes. Ao considerar a história como uma construção humana, a reflexão sobre poder, juntamente com a análise de suas formas de exercício, não é concebida como uma opção intelectual pessimista ou uma visão demoníaca da vida; pelo contrário, é um caminho pelo qual, negando o determinismo histórico, os homens podem construir conscientemente o seu destino (CARVALHO; VIEIRA, 2007).

O jogo de poder nas organizações é um processo dinâmico e, por essa razão, os elementos formais da estrutura organizacional adquirem um caráter igualmente dinâmico, já que sua mudança representa fonte de informação sobre a alteração do arranjo de poder dentro da organização. A autoridade associada a algum cargo na estrutura hierárquica da organização tem normalmente como fonte de poder a especialização. Uma mudança no tipo de demanda do ambiente pode diminuir a importância de algumas posições, alterando o arranjo de poder entre as posições de indivíduos e grupos (MORGAN, 1996; HALL, 2004; CLEGG, 1981).

\subsubsection{Poder}

Embora o poder seja um tema central na análise de qualquer fenômeno social, ele é considerado um tema árduo e, por essa razão, são poucos estudiosos que se sentem preparados para abordá-lo em seus estudos. No entanto sua importância para a compreensão das organizações e seus processos é inegável (CARVALHO; VIEIRA, 2007). Várias definições de poder foram apresentadas por estudiosos do tema. Salancik e Pfeffer (1974) sugerem que o poder advém da capacidade de alguns atores de extrair recursos do ambiente. Para Hickson et al. (1971), os atores que têm mais poder são aqueles que conseguem lidar com as incertezas do mercado. Segundo Pfeffer (1981), o poder é desenvolvido e implementado através da rede de relações. As relações sociais estão incorporadas ao conceito de network, de maneira que o acesso à informação e a influência dependem fortemente de com quem as pessoas estão conectadas.

A concepção de poder, muitas vezes, é confundida com a de liderança, no entanto são concepções distintas, em que o poder pode ser uma resultante da liderança. 
O poder pode ser concebido como a capacidade de agir do indivíduo e também como a capacidade de determinar o comportamento de outro indivíduo. O conceito de poder deve considerar tanto as ações como as inações dos seus atores. Essa definição traz a noção das consequências das ações, independentemente do que elas possam ser ou o que as provoca. Nesse sentido, o poder é visto como um fenômeno social que acontece na relação entre os homens e entre os grupos que eles formam. Hall (2004) considera o poder como um ato, portanto os resultados de um ato de poder podem originar, dentre outros fenômenos, a obediência ou o conflito. Bachrach e Baratz (1983), ao salientarem o aspecto relacional do poder, trazem uma mudança no significado dessa palavra, na medida em que enfatizam a dependência entre as partes. Surge, portanto, o papel do receptor, o indivíduo sobre o qual o poder é exercido e que é determinante na identificação do tipo e da forma da ocorrência do ato de poder. Apesar de enfoques diferentes, essas concepções de poder situam-se na categoria assimétrica de poder, que pressupõe relações sociais e políticas desiguais, em luta por recursos de poder e que desenvolvem práticas de resistência e conflito (CARVALHO; VIEIRA, 2007).

French e Raven (1959) propuseram cinco bases de poder. Essas determinantes de poder se assentam nas relações interpessoais entre detentor e receptor de poder: 1) coerção (capacidade do primeiro de punir o segundo pelo não cumprimento das exigências); 2) recompensa (possibilidade de o influenciador recompensar o influenciado); 3) legitimidade (aquisição do direito do detentor de agir com autoridade); 4) referência (baseia-se na vontade do receptor de imitar e se identificar com o detentor); 5) especialização (refere-se ao reconhecimento da competência do influenciador). Foi acrescentado a essas cinco bases de poder, por Bacharach e Lawler (1980), o acesso à informação ou ao conhecimento como um importante determinante de poder. Esses autores propõem quatro aspectos que são cruciais. São eles: 1) o cargo ou a posição na estrutura organizacional; 2) as características pessoais determinantes, por exemplo, o carisma; 3) a especialização, que é a formação profissional que os indivíduos trazem com eles e 4) a oportunidade ou a combinação de fatores que oferece ao indivíduo oportunidade de realizar suas bases de poder. É possível perceber que o exercício do poder nas organizações é um assunto complexo e que depende de uma série de variáveis combinadas para que ele ocorra.

Para Morgan (1996), são fontes importantes de poder nas organizações: a autoridade formal, o controle de recursos escassos, o uso da estrutura organizacional mediante regras e regulamentos, o controle dos processos decisórios, o conhecimento e 
a informação, o controle de fronteiras e a tecnologia, a habilidade para lidar com as incertezas, as alianças interpessoais, os simbolismos e o gerenciamento de significados, os fatores estruturais e de gênero, o poder que a pessoa já tem e o controle sobre a contraorganização, como os sindicatos e associações de consumidores. Nesse mesmo sentido, Pfeffer (1992) define o poder como o estar no lugar certo, sendo que esse estar no lugar certo ou em uma boa posição significa obter recursos de poder. Os recursos podem ser desde o controle sobre recursos como orçamento e a posição que contribua para o cultivo de aliados e apoiadores; o controle e o acesso à informação que permita saber o que está acontecendo e as preferências e os julgamentos dos outros, além da autoridade formal, que esta relacionada a estar na subunidade certa.

A utilização das bases e fontes de poder para análise do poder nas organizações, segundo Clegg e Dunkerley (1991), apresenta um problema inevitável por considerar que, a priori, as origens do poder têm uma utilidade explicativa para toda e qualquer situação de realização de poder nas organizações. Todavia a riqueza e a diversidade demonstradas pelo cotidiano das organizações desmentem o caráter invariável e universal desses elementos explicativos.

Um dos autores que trataram da noção do poder simbólico foi Bourdieu (1989), que esclareceu que o poder não se define pela posse de uma propriedade ou um recurso, como defendem os autores que se apoiam nos determinantes de poder, mas pelo reconhecimento pelos outros atores sociais dessa propriedade ou desse recurso e pelo valor dado a estes. Nesse sentido, o controle dos significados sociais representa a principal fonte de poder dos atores no jogo político. Se, por um lado, esses significados são gerados pelo grupo dominante (indivíduos conhecedores das regras do jogo político e detentores do habitus necessário para participar dele) no seu campo intelectual. Por outro lado, a conquista de posições de poder depende do nível em que esse discurso obtém adesão e legitimidade por parte dos "leigos" (indivíduos ou instituições que não pertencem ao campo de poder, mas que formam o capital social necessário para legitimar os conceitos vigentes). O poder simbólico ou poder subordinado é uma forma transformada, irreconhecível, transfigurada e legitimada das outras formas de poder. É o poder de fazer ver o que não é visto, de consagrar o que existe e de criar coisas novas, por meio do poder do ator legitimado. No entanto o indivíduo deve ter uma quantidade mínima de propriedades, como conhecimento, talento ou habilidades, que o torne apto a jogar o jogo de uma estrutura específica. Essas propriedades representam um capital 
simbólico que oferece ao ator prestígio, honra e consagração, o que contribuirá para que os outros agentes o vejam como um jogador legítimo.

Outra forma de avaliar o poder é pelo enfoque do indivíduo e do ser humano. Para Ramos (1981), o indivíduo é um ser que se comporta nas organizações e em sociedade e, por estar integrado a elas, representa papéis. Quando um indivíduo assume um papel social, logo outro papel complementar em oposição surge automaticamente, por exemplo, líder e liderado. Os indivíduos buscam papéis que lhes permitam expressar suas motivações e desejos. Um papel importante no ambiente organizacional, que possibilita essa expressão, é o papel de liderança. Por essa razão, muitos profissionais buscam ocupar essa posição na organização (VIEIRA; PEREIRA; ROSCOE, 2010). Os papéis na organização estão em constante mudança, com maior fluidez nas responsabilidades e atribuições por projeto. Essas mudanças nas organizações e aquelas projetadas para o futuro sugerem que as interações sociais serão ainda mais características dos ambientes de trabalho contemporâneos e futuros (HOOIJBERG; HUNT; DODGE, 1997). A visão do poder do ponto de vista do indivíduo pode ter uma base no conceito de função social do movimento funcionalista. A função social é a contribuição que um fenômeno provê a um sistema maior do que aquele ao qual o fenômeno faz parte. Esse uso técnico não é o mesmo da ideia popular de função como um evento, obrigação ou profissão. A grande crítica sobre essa visão reside no fato de que, como num organismo vivo, haverá a tendência em identificar partes mais importantes como os órgãos vitais, justificando, assim, a existência, manutenção ou extinção daqueles considerados como menos importantes. Conforme alguns opositores, a teoria funcionalista sustenta que conflito e disputa é danosa à sociedade, tendendo a ser a visão dos pensadores conservadores (HOULT, 1969; MERTON, 1957; MARSHALL, 1994).

O poder pelo enfoque do ser humano considera que este é um ator social e sujeito de suas ações e decisões na sociedade. As ações são próprias de um agente que delibera sobre coisas porque está consciente de suas finalidades intrínsecas. Em razão do reconhecimento dessas finalidades, a ação constitui uma forma ética de conduta. Para Matus (1996), o ator social é participante de um jogo, produtor e produto do sistema social. Os jogadores não são livres para controlar o resultado de suas ações, já que a participação no jogo pode ser limitada, anulada ou amplificada pelos outros e pela eficácia da própria ação. Em um jogo social não participam apenas atores, mas também a população não organizada, indivíduos etc. $\mathrm{O}$ ator não joga sozinho, mas em interações 
de cooperação ou confronto com o outro. Para esse autor, o ator social é um ser criativo que não segue leis e tem um comportamento imprevisível. Para outros autores, como Bourdieu (1989), as regras da disputa por posição são definidas pelo habitus, sendo o habitus um sistema de disposições de modos de pensar, agir e perceber. Essa abordagem traz a visão de que a relação do ser humano com o poder está circunscrita por regras e disciplina.

O principal pensador contemporâneo sobre o poder que trabalha essa visão das regras e disciplina é Michael Foucault. Esse autor escreveu obras complexas e abrangentes sobre o poder (Verdade e poder, 1979; Vigiar e punir, 1987; O sujeito e o poder, 1995; Microfísica do poder, 1979, entre outros). Neste estudo, todavia, serão feitas citações sucintas e provavelmente superficiais, por não ser esse o objetivo principal do trabalho. A intenção aqui é de trazer apenas a ideia central da análise foucaultiana do poder e tentar relacioná-la ao objeto deste estudo. Esse autor trabalha a concepção de um regime de biopoder que apresenta dois mecanismos fundamentais: as disciplinas e a biopolítica. As disciplinas se referem ao controle do corpo do indivíduo por meio do seu adestramento para torná-lo dócil e submisso. A biopolítica age sobre um conjunto de processos populacionais exercendo efeitos no corpo coletivo. O poder disciplinar é aquele que mais facilmente descreve as relações de poder dentro das organizações. Isso porque o mecanismo disciplinar aborda questões relacionadas à distribuição e à organização dos indivíduos no espaço, ao controle e à avaliação de suas atividades, em razão de um emprego eficaz do tempo. Trata da divisão das atividades e sua combinação em níveis de complexidade, do estabelecimento de prazos, da ordenação de atividade e do efeito sinérgico que esses movimentos exercem na composição de forças de todo o dispositivo normalizador. Para Foucault (1987), o sucesso do poder disciplinar é garantido pelo uso de instrumentos simples, como o olhar hierárquico, a sanção normalizadora e a sua combinação em procedimento específico: o exame. Motta e Alcadipani (2004), em uma análise sobre o papel das obras de Foucault no pensamento das teorias organizacionais, apontam que o poder disciplinar de Foucault consegue analisar as relações de poder presentes no paradigma taylorista/fordista de produção. Todavia, quando os teóricos organizacionais se voltam para práticas de gestão mais atuais, como empowerment e equipes de trabalho, nuances e variações sobre a operação do poder nas organizações se apresentam. Muito embora a noção do poder disciplinar seja ainda importante para compreender uma parte considerável das dinâmicas da relação de poder, ela apresenta limitações nesse contexto. 
Toffler (1991), ao analisar o quadro da vida social e econômica, considerando suas atualizações no seio organizacional, entende que, depois de ultrapassada a lógica do homo economicus, em que a riqueza era, por excelência, a base de poder, mais recentemente o poder se configura como de outra natureza. É cada dia mais comum uma quantidade considerável de negócios emergirem, fruto de formação, da informação, do conhecimento e da criatividade, fazendo dos detentores do conhecimento os ímãs do poder. Multiplicam-se os casos de organizações que utilizam o conhecimento para exercer o poder. Por essa razão, aumentou-se a relevância de temas como a confiança, o envolvimento, o comprometimento e os comportamentos extrapapel na agenda dos líderes organizacionais. Para esse autor, está-se perante um novo paradigma de gestão das organizações, que equipara o poder ao conhecimento. Esse novo paradigma de poder faz refletir sobre o fato de que, apesar de o poder no ambiente organizacional ser assimétrico, em razão de informações e conhecimentos privilegiados em relação a estratégias dos profissionais que ocupam altos cargos na organização, ele tende a se tornar mais simétrico, na medida em que, por exemplo, um jovem profissional que conheça uma nova tecnologia capaz de trazer grandes resultados para a empresa passe a exercer um grande poder naquele contexto, fato esse, que não ocorreria em um passado recente. A possibilidade de o conhecimento estar acessível e presente em qualquer profissional, independentemente do seu cargo ou nível hierárquico, altera a lógica das interações sociais dentro da organização, impondo a necessidade de uma abertura para escutar as diferentes vozes nesse espaço.

Nessa mesma lógica, Sant’Anna (2010) fez uma análise das competências das lideranças gerenciais, tema deste estudo, sob a perspectiva foucaultiana de poder. Para esse autor, a análise dos trabalhos de Foucault sobre o poder disciplinar mostra que o desenvolvimento de competências reflete pressupostos básicos do mecanismo disciplinar. No entanto, no contexto atual, observam-se demandas organizacionais por um leque de conhecimentos, habilidades e atitudes profissionais cada vez mais amplo e sofisticado, de modo a intensificar o dilema entre a necessidade de perfis que extrapolem a norma e a demanda por controle. Sant'Anna (2010) parte da premissa de que a liderança constitui-se de atributos localizados no "furo das barras", justamente na região em que os modelos de gestão tradicionais, calcados na noção de disciplina e de normalização, não são capazes de dar resposta. Diante de tal situação, o desafio que se apresenta, segundo esse autor, tem outra magnitude e levanta reflexões sobre algumas questões: como desenvolver modelos que permitam às organizações lidarem com perfis 
e atributos que se encontram além das faixas de normalidade, ou seja, do poder disciplinar? Como construir e lidar com ambientes organizacionais em que esse novo espectro de perfis e competências tenha campo para operar? A questão é que essa perspectiva pressupõe uma nova racionalidade organizativa, uma nova analítica do poder, que supere o imperativo da disciplina. Uma era que estaria para além das prerrogativas do poder disciplinar e da biopolítica e que compreenderia novos perfis de liderança e dispositivos para desenvolvê-los.

\subsubsection{Política}

A palavra política tem origem nos tempos em que os gregos se organizavam em cidades-Estado chamadas "polis", que, por extensão, pode também significar sociedade, comunidade ou coletividade. A política denomina-se a arte ou ciência da organização, direção e administração de nações ou Estados. Para Aristóteles (2010), o homem é naturalmente um animal político. A política, como forma de atividade ou de prática humana, está estreitamente ligada ao poder. No entanto, no conceito amplo de política, o poder deve ser exercido por um governante em benefício dos governados. Segundo Bourdieu (1998), a política é lugar, por excelência, da eficácia simbólica, ação que se exerce por sinais capazes de produzir coisas sociais. E, dessa forma, o poder só existe na medida em que os mandatários plenos de poder podem sentir-se autorizados a falar em nome da política e fazê-la existir. É no campo político que os profissionais da representação se opõem a respeito de outro campo de lutas simbólicas. Os discursos políticos apresentam uma espécie de duplicidade estrutural: na aparência, são diretamente destinados aos mandantes, no entanto, na realidade, são dirigidos aos concorrentes no campo. Para Bobbio (2002), os fins da política são tantos quantas são as metas que um grupo organizado se propõe, de acordo com os tempos e circunstâncias. Neste estudo, emprega-se o termo "política" dentro de um contexto organizacional e, para tanto, utiliza-se a noção de política descrita por Morgan (1996).

A noção de política nasce da ideia de que, quando os interesses são divergentes, a sociedade deve oferecer meios que ajudem os indivíduos a reconciliarem as suas diferenças por meio da consulta e da negociação. Nesse mesmo sentido, Aristóteles (2010) via a política como uma preciosa ferramenta que fornecia meios para criar a ordem na diversidade, enquanto se evitavam formas e regras totalitárias (MORGAN, 1996). O termo "política" refere-se à gestão e ao processo de tomada de 
decisão dentro de grupos sociais. A política na organização significa o processo de influência para gerenciar os interesses múltiplos que competem entre si dentro da organização.

Para Pfeffer (1981), a política organizacional pode ser definida como as ações desenvolvidas dentro da organização para adquirir, desenvolver e utilizar o poder e outros recursos para obter o resultado preferido por alguém em uma situação de incerteza ou falta de consenso sobre as alternativas existentes. A política nas organizações está relacionada à obtenção de poder por meio do controle dos recursos organizacionais (DORY; ROMM, 1990). A política nas organizações surge dos conflitos em relação à escassez de recursos que ocorre em ambientes caracterizados pela ambiguidade e também pela existência de grupos interdependentes com interesses, crenças e metas heterogêneas. Na medida em que as organizações passaram a adotar estruturas mais planas e menos burocráticas, o controle sobre os recursos se torna ainda mais ambíguo e a politização ainda mais predominante (PFFEFER, 2010).

A política nas organizações é um conceito de caráter universal e onipresente. Contudo é comum os indivíduos reconhecerem política como jogar o jogo, trabalhar conforme o sistema e negociações paralelas. A visão mais comum sobre a política é definitivamente negativa e a maioria das pesquisas sobre política é dedicada aos seus aspectos disfuncionais. No entanto alguns autores têm defendido a importância de explorar os aspectos positivos da política na organização, entendendo que os líderes podem e devem atuar politicamente para fins benéficos. A adoção de um conceito neutro de política que elimine uma definição carregada de valores pode resultar em uma distinção do comportamento político como um conjunto de características que não sejam exclusivamente positivas ou negativas, ampliando o construto de política nas organizações (FERRIS; TREADWAY, 2012). Segundo Sederberg (1984), a política na organização é a tentativa de criar, manter, modificar ou abandonar os significados compartilhados. Considerando que os significados compartilhados são geridos pelo processo político, a política torna-se um importante aspecto das conquistas pessoais e organizacionais (LUTHANS; ROSENKRANTZ; HENNESSEY, 1995; PFEFFER, 1981).

Grande parte das pesquisas sobre política foi desenhada com base na raiz teórica de tomada de decisão e poder. Posteriormente, Ferris et al. (1989); Ferris et al. (2005); Ferris et al., 2007) incrementaram os estudos de política no nível micro, examinando a percepção da política nas organizações em relação aos seus antecedentes, 
fatores de moderação e resultados da percepção de outros em relação ao ambiente político. Esses autores utilizaram a noção de vontade política e habilidade política cunhada por Mintzberg (1983) para avaliar como os indivíduos funcionam efetivamente nas organizações. Diferentemente das pesquisas de nível macro, as pesquisas na área têm acumulado um significativo corpo de pesquisas empíricas e sistemáticas focadas nos atores políticos (LEPISTO; PRATT, 2012). Nesse estudo, seguiu-se o caminho trilhado por Ferris et al. e considerou-se a política no nível micro, que trata dos atores políticos no ambiente organizacional, e pela adoção de um conceito neutro de política.

A perspectiva política nas organizações é frequentemente creditada a suposições teóricas fundamentadas pela Escola Carnegie, assim como pela Teoria da Firma Baseada em Recursos e a Teoria Instrumental (PFFEFER; SALANCIK, 1978). Essas perspectivas contrastam com a perspectiva econômica das organizações, que tende a focar as reivindicações normativas para eficiência, a maximização da utilidade e a falta de conflito nas tomadas de decisão. A Escola Carnegie trabalha com o conceito de racionalidade limitada de Simon (2002) e enfatiza como as tomadas de decisões nas organizações são influenciadas pelas informações, pelos valores, pelas rotinas e pela desagregação de objetivos e metas. Uma organização não é composta de atores únicos, com os mesmos objetivos; pelo contrário, é composta por múltiplos atores com diferentes objetivos. As organizações superam a paralisia dos efeitos da competição de objetivos ao aceitarem que nunca alcançarão uma solução ótima, todavia elas existem e prosperam mesmo com um conflito latente e um número considerável de objetivos distintos (CYERT; MARCH, 1963; LEPISTO; PRATT, 2012). O que alguns autores defendem na atualmente é que as organizações utilizem os conflitos e a competição de maneira positiva.

Enquanto a escola Carnegie focaliza a tomada de decisão, o trabalho de Selznick $(1966,1997)$ sobre a Teoria Institucional evoca uma noção similar sobre a política nas organizações, no entanto dá ênfase à relação gestão dos valores e competição de interesses. Esse autor descreve o papel da liderança no processo de institucionalização e mostra como as organizações se tornam imbuídas de valores. Para ele, aquele que sabe transformar um grupo de pessoas neutras em políticos comprometidos pode ser chamado de líder; a profissão dos líderes é a política. Selznick (1966, 1997) explica como os interesses externos à organização, sejam formais ou informais, influenciam a liderança e os domínios políticos da organização. Sua pesquisa 
mostra que a política não se relaciona apenas às tomadas de decisão, mas implica também nos valores de gestão, liderança e poder.

Lepisto e Pratt (2012) fizeram uma revisão de várias definições de política nas organizações e identificaram cinco clusters de características e elementos que capturam e sintetizam, segundo esses autores, os elementos necessários e suficientes para a definição de política nas organizações: (1) um ator (individual) ou atores (grupo); (2) interesse próprio e meta direcionada; (3) ações de poder e influência social; (4) interdependência entre dois ou mais atores sociais interdependentes; (5) meios que não são oficialmente sancionados. Dessa forma, esses autores caracterizam a política na organização como uma série de condições necessárias, mas não suficientes. A utilização desse cluster pode contribuir para um entendimento comum que pode ser utilizado na literatura pelo seu poder de síntese.

\subsubsection{Poder e politica organizacional}

O papel do poder na política é discutido em dois trabalhos relevantes sobre o tema: o trabalho de Pffefer (1981), em seu artigo "O poder nas organizações" (Power in Organizations) e de Mintzberg (1983), "O poder nas e em torno das organizações" (Power in and Around Organizations). Pffefer (1981) equipara o poder explicitamente à habilidade de um ator, comparado a outros atores, em adquirir e controlar recursos valiosos. Para ele, se o poder é uma propriedade das relações baseadas em recursos e dependência, a política pode ser vista como o poder em ação. Os atores podem utilizar uma variedade de táticas, como controle da informação, desenvolvimento de coalizões e incorporação de especialistas externos.

Já Mintzberg (1983) vê a política como um sistema alternativo de influência dentro das organizações. Esse sistema pode ser usado em conjunto com, em contraste a ou em substituição a outros sistemas de influência, incluindo os sistemas de autoridade, ideologia e expertise, sendo os três tipos baseados relativamente em uma fonte legítima de poder. A autoridade formal é equiparada ao poder que é formalmente legitimado ao se ocupar um cargo específico. A ideologia foca o poder relativo ao compartilhamento de valores e crenças. E a expertise é a legitimação do poder derivado do conhecimento específico e habilidade em um domínio particular. Mintzberg (1983) apresenta uma perspectiva um pouco diferente de Pffefer (1981). Para ele, a política é mais análoga ao 
poder informal. No entanto aquele autor descreve o sistema político como legítimo em seus fins.

No livro O poder nas organizações, Carvalho e Vieira (2007) apresentam uma visão introdutória sobre o tema, no entanto com rigor quanto às concepções centrais para o estudo da política nas organizações nos tempos atuais. Esses autores exploram diferentes perspectivas do poder, centradas nas organizações. Inicialmente, eles se referem à perspectiva de autoridade baseada no estudo de Weber (1978), que trata da estrutura formal da organização, que representa o espaço social efetivo de exercício do poder. Já a abordagem da economia política é pautada nos estudos de Zald (1970), que considera a organização como um locus de dominação. Eles utilizaram ainda o conceito de campo social, de Bourdieu (1989), para explicar as organizações como arenas de jogos de poder entre os atores sociais. Carvalho e Vieira (2007) se inspiraram em Pagès (1987) que concebe as organizações como estruturas de dominação integradas ao seu contexto sócio-histórico nos níveis mundial, continental e nacional. Pagés (1987) traz a perspectiva de poder como mediação, que constitui uma estratégia das organizações para gerar contradições nas pessoas. Essas contradições se dão na medida em que, ao mesmo tempo em que oferecem oportunidades que representam benefícios, por outro lado, impõem restrições que aprisionam os indivíduos. E, finalmente, a perspectiva de Foucault (2002), que considera o poder como prática social e disciplina dos homens.

Segundo Miranda (2009), nas últimas décadas, testemunhou-se a redescoberta do estudo do poder e do comportamento político nas organizações, praticamente adormecido desde os trabalhos de Weber (1947). Essa retomada foi fortemente influenciada por alguns acontecimentos capitais, como é o caso da entrada nas organizações de cidadãos conscientes, atentos e socializados com a atividade política. Segundo a autora, essa evolução não aconteceria se as ciências organizacionais não tivessem superado a velha lógica racionalista (MIRANDA, 2009).

\subsubsection{Poder e influência}

A política é vista como uma forma de conseguir que as coisas sejam realizadas em um grupo, sendo, portanto, um fenômeno eminentemente social. A realização das coisas é alcançada por meio do poder ou da influência social. Enquanto alguns autores equiparam poder e influência social, outros reconhecem que o poder é frequentemente atrelado à autoridade formal, à rede de relacionamentos e à estrutura (PFFEFER, 1981), 
já a influência tende a ser mais localizada, em bases informais para ganhos de complacência, como a reciprocidade ou afeição. Tanto o uso do poder quanto o ganho de conformidade via influência são importantes para a conceituação de política nas organizações. O poder é uma forma de atingir o interesse próprio e uma meta dirigida.

No comportamento político, o interesse próprio não é apenas um componente, mas é, presumidamente, o componente mais importante. Ressalte-se que, se a política refere-se às coalizões ou aos atores individuais nesse processo de influência social, sua ocorrência sempre terá o propósito de alcançar algum objetivo. Portanto a política envolve atividades naturalmente sociais e orientadas para metas. A política parece prevalecer quando práticas oficialmente sancionadas não estão disponíveis, são vistas como não efetivas ou pouco efetivas para o alcance de metas (LEPISTO; PRATT, 2012).

Segundo Pfeffer (1992), as pessoas são influenciadas não apenas pelo contexto das situações, mas também diretamente pela ação dos outros, ou seja, pelo que os colegas estão dizendo ou fazendo. Os profissionais buscam aprovação social. As pessoas são seduzidas pelas coisas que as outras pessoas fazem para que gostem dela e se sintam bem em relação a elas. Outro fator de influência são as emoções que são criadas e usadas no contexto social. A incerteza é um aspecto universal da vida nas organizações, e os profissionais são constantemente impelidos a fazerem julgamentos e desenvolver ações sob condições de ambiguidade. Uma forma de as pessoas lidarem com esse ambiente de incerteza e ambiguidade é por meio da comunicação social informal, perguntando a opinião dos seus associados. Atitudes, percepções e escolhas são comparadas com os outros, particularmente, outros que são similares ou próximos. Essas visões compartilhadas servem para influenciar a visão da própria pessoa. Crenças e julgamentos são socialmente ancorados, e a realidade se torna uma construção social consensual. Uma das formas de profissionais e organização conseguirem que as coisas sejam realizadas é contar com atalhos no processamento da informação. A influência interpessoal é uma parte onipresente da vida social que não pode ser evitada. $O$ fato de as pessoas viverem em um mundo social em que as organizações são sistemas sociais interdependentes significa que, para conseguir que as coisas sejam feitas, é preciso a ajuda dos outros. É essencial que as pessoas tenham habilidade de aceitar a definição dos outros sobre a situação e seguir as regras do comportamento que assegurem as interações de cooperação. 
Além da discussão sobre a relação entre os construtos poder, política e influência, definiu-se por elaborar duas sessões sendo uma referente à política e racionalidade e a outra sobre política e contexto. Isso porque essas questões aparecem de maneira recorrente e podem contribuir para a análise e discussões sobre a temática.

\subsection{Política e racionalidade}

Para Miles (1980), a vida nas organizações envolve contradições originadas de duas realidades: a racional e a política. Tushman (1977) acredita que a perspectiva política não aparece nos estudos organizacionais como um substituto da visão racionalista, mas como seu complemento. Para esse autor, essas duas versões não devem ser consideradas como mutuamente excludentes.

As situações de incerteza ou falta de consenso dentro das organizações são cada vez mais comuns, em razão das ambiguidades e da exposição constante às mudanças no ambiente organizacional e fora dele que geram a necessidade de respostas rápidas a elas. As empresas ainda trabalham com a ideia de que as soluções dos problemas e tomadas de decisões são, predominantemente, racionais. Essa ideia de que as pessoas são, de modo geral, racionais, foi questionada nos estudos sobre a tomada de decisão de Tversky e Kanehman (1985). Em seus estudos, esses autores demonstram que as decisões são influenciadas por heurísticas, que são estratégias simplificadoras, atalhos ou regras práticas que as pessoas utilizam ao tomar decisão e por enviesamentos, que são interferências no processo de tomada de decisão que atuam nas heurísticas de modo a deturpar a realidade percebida. Os vieses podem ser de origem cognitiva ou emocional. As heurísticas, que podem ser de disponibilidade, representatividade e confirmação, levam as pessoas a lidar com vieses nas tomadas de decisão, por exemplo, a facilidade de lembrança, a interpretação errada da chance ou o excesso de confiança.

Kahneman (2012), que ganhou o prêmio Nobel de Economia ressalta que, apesar dos vieses no processo de tomada de decisão, tais vieses não significam que as escolhas humanas sejam irracionais. Segundo esse autor, "irracionalidade" é uma palavra forte que denota impulsividade, emoção, teimosia que resiste a argumentos sensatos. Para ele, a definição da racionalidade como uma coerência lógica, seja ela sensata ou não, foge do significado comum de que uma pessoa racional é também uma pessoa sensata. Segundo a conclusão do autor, os humanos não são bem descritos pelo 
modelo de agente racional, o que não significa que os humanos são irracionais. Para Kahneman (2012), as imperfeições nas percepções humanas levam à violação sistemática dos requisitos de coerência e consistência. Os humanos são suscetíveis à impulsão, à perspectiva interna, à inversão de preferência e, segundo o autor, os humanos não conseguem evitar, de forma consistente, questões como essas. No entanto, apesar de não serem irracionais, os humanos precisam, muitas vezes, de ajuda para fazerem juízos mais exatos e tomarem melhores decisões. Em alguns casos, as políticas e instituições podem fornecer essa ajuda.

Nesta pesquisa, trabalhou-se o aspecto político nas organizações da mesma forma que Kahneman (2012) trata as heurísticas e vieses no processo de tomada de decisão, ou seja, descrevendo como as coisas, de fato, acontecem, sem negar sua natureza humana. A questão política nas organizações trata de um aspecto do ser humano que descreve sua natureza social por ser influenciado e influenciador nas interações sociais, no contexto organizacional, inclusive, e pelo desejo de progredir e de se relacionar bem com as outras pessoas.

Para Buchanan e Badham (1999), a crescente incerteza organizacional e a racionalidade limitada foram fatores responsáveis pela queda da organização racional e pelo advento da organização política. Segundo Crozier e Friedberg (1980), o aparecimento da organização política ocorre principalmente por um fenômeno ligado às representações e às capacidades cognitivas. Isso porque cada profissional enxerga a organização sob o ângulo dos seus objetivos; cada pessoa tem um campo de competência particular e conhecimentos limitados por esse campo.

Existe um movimento nas organizações classificado como "despolitização" das tomadas de decisão. A intenção dele é de tornar o ambiente corporativo mais democrático e transparente, na medida em que elimina o veto único e proporciona oportunidades para que todas as novas ideias possam competir por apoio abertamente. Em um ambiente democrático, os líderes políticos têm de enfrentar os seus críticos. Invariavelmente, a abertura e as divergências de opinião melhoram a qualidade das decisões e garantem que as más políticas sejam reexaminadas e revistas mais rapidamente do que seriam de outra forma. Nesse cenário, os executivos devem se interrogar se os processos de gestão da sua empresa realmente encorajam o desacordo (HAMEL; BREEN, 2007).

Os gestores são vistos pela área dos estudos de decisões estratégicas como tomadores de decisão. No entanto Burns (1961) alerta que sempre que a atividade 
política é discutida no ambiente organizacional, absolutamente ninguém se vê na figura de um político ou agindo como tal. Exceto, é claro, quando se trata de comportamentos e atividades para salvaguardar e defender os mais elevados interesses da organização. No entanto o processo de tomada de decisão é sempre complexo, por envolver falta de informações, pressão do tempo e aspectos políticos. Essa área de estudo defende a busca pela racionalidade a fim de melhorar as tomadas de decisões e evitar vieses. No entanto todos os gestores estão suscetíveis a vieses em razão do stress, da fatiga, de multitarefas, da confiança na sua intuição e da falta de fundamentação (SOLL; MILKMAN; PAYNE, 2015).

Eisenhart e Bourgeois (1988) elaboraram um trabalho com o objetivo inicial de entender como a política opera quando os times de alta gerência tomam decisões estratégicas. Alguns autores indicam que a raiz do comportamento político é o conflito. O estudo mostrou que o conflito afeta a política, no entanto ele não é uma condição suficiente para uso da política. A atividade política tem sido descrita como alianças temporárias e mutáveis. No entanto a pesquisa sugere que os padrões de coalizão são estáveis, em virtude de: 1) ambiente de alta velocidade nas decisões; 2) incerteza de informação e complexidade do ambiente real, indicando que quanto maior o uso da política na equipe de alta gerência, maior a chance de padrões de alianças estáveis. Os padrões de alianças estáveis surgem porque equipes politicamente ativas têm culturas estressantes, que levam os executivos a confiar em respostas como coalizões estáveis, além do fato de os executivos não se envolverem num processo extensivo cognitivo, necessário para verificar as preferências dos outros e planejar as ações políticas. A pesquisa de Eisenhart e Bourgeois (1988) sugere, ainda, que as alianças se desenvolvem com base em fatores demográficos como idade, localização do escritório, similaridades de cargos e experiências anteriores juntos. Foi observado que os padrões estáveis de comportamento político se desenvolvem lentamente, mas, quando formados, demoram a mudar. Com o tempo, um padrão de aliança estável ocorre em grupos politicamente ativos e permanece mesmo que as condições que geraram o surgimento não mais estejam presentes. $\mathrm{O}$ uso da política pode ser considerado vantajoso em ambientes de mudanças rápidas porque serve como um mecanismo importante de adaptação.

A ideia de exposição dos tomadores de decisões a um comitê, por exemplo, tem o objetivo de incentivar argumentações que sejam pautadas mais na racionalidade do que em interesses escusos. Essa postura em relação à tomada de decisão contribui para um ambiente propício à inovação e pouco favorável à "politicagem". Todavia o 
termo politicagem, nesse contexto, está relacionado à percepção mais comum do comportamento político que é, sem dúvida, disfuncional. Nesse sentido, o pensamento que predomina nas organizações é de que seria melhor se elas pudessem eliminar os comportamentos políticos e então todas as questões seriam postas às claras e as manobras de bastidores deixariam de acontecer (DAVID; GARDNER, 2004; FERRIS et al., 2002; FEDOR et al., 2008).

Não há dúvidas de que o comportamento disfuncional nas organizações deve ser inibido e que os métodos racionais contribuem para extirpar argumentações baseadas no ego, no interesse próprio ou na primazia das relações pessoais em detrimento dos objetivos comuns e da valorização da competência dos envolvidos. No entanto, é preciso que as organizações e seus gestores consigam distinguir o comportamento político funcional e o disfuncional. Existe uma distinção na literatura entre a política do dia a dia e o comportamento político extremo, que viola as regras do “jogo". Alguns pesquisadores reconhecem que essa distinção e a possibilidade de uma visão positiva do comportamento político contribuem fortemente para $o$ desenvolvimento de teorias políticas de liderança (HOUSE; ADITYA, 1997; BASS; BASS, 2008).

A natureza positiva ou negativa do comportamento pode ser vista em razão da atribuição da intenção dos seus atores ou aos resultados pessoais e organizacionais associados a ele (DAVID; GARDNER, 2004; FERRIS et al., 2002; FEDOR et al., 2008). Afinal de contas, o processo de tomada de decisão (a definição da escolha de um projeto ou a implementação de uma ideia) não deixa de ser um processo político, mas, nesse caso, o termo político está relacionado ao conceito de política em um sentido neutro. As intenções e os resultados dessa decisão é que definirão sua funcionalidade ou não. Todos os profissionais envolvidos nos processos de tomada de decisão sempre serão influenciados e influenciadores, e aqueles que desejarem defender suas ideias precisarão da competência política.

Nesse sentido é que se faz clara a importância da adoção de um conceito neutro da política e da aceitação da sua perspectiva positiva nas organizações. Mintzberg (1985) descreve o sistema de influência político como aquele que obriga o "homem responsável" a brigar pelo que acredita ser certo, encoraja uma variedade de "vozes" que necessitam ser ouvidas sobre um determinado assunto. Em razão dos ataques de seus oponentes, cada "voz" é obrigada a tirar suas próprias conclusões em relação às necessidades da empresa como um todo. Esse sistema parece servir para o atendimento 
do interesse comum da organização e não para interesses de um grupo em particular. Essa descrição vai de encontro ao pensamento comum de que a política é usada exclusivamente para o benefício próprio.

Cabral-Cardoso (1995) realizou um estudo empírico e defendeu que muitos indivíduos que utilizam técnicas e modelos matemáticos de forma instrumental creem que esse é o modo "racional" de tomar decisões, sendo levados a procurar convencer os outros intervenientes da superioridade da sua argumentação. No entanto essas técnicas podem ser utilizadas também com intenções políticas, e sua eficácia, segundo esse autor, só ocorrerá se ela deixar transparecer uma imagem de racionalidade e consistência, aumentando a possibilidade de influência na decisão final. Nesse mesmo sentido, Pfeffer (1992) afirma que, muitas vezes, informações são utilizadas de forma seletiva para promover a opção favorita de uma pessoa em um processo de tomada de decisão. O uso seletivo de informação pode parecer um comportamento puramente de interesse próprio. No entanto esse autor alerta que essa atitude pode envolver, além do interesse próprio, a perspectiva particular do indivíduo. Ele defende que, por meio do processo de comprometimento, indivíduos acreditam naquilo que fazem. A maior parte das decisões gerenciais é tomada em condições de incerteza e, portanto, os indivíduos preferem utilizar tanto os dados como os processos que os façam se sentir mais confortáveis na tomada de decisão. Pfeffer (1992) alega ainda que a busca por modos "racionais" gera uma sensação de conforto aos tomadores de decisão. No entanto é preciso admitir que a motivação política pode, em algumas circunstâncias, aparecer travestida pelas técnicas e modelos matemáticos.

Morgan (1996) acredita que a racionalidade é sempre política. Ninguém é neutro na administração de organizações. A metáfora política elaborada por esse autor enfatiza que as metas organizacionais podem ser racionais para o interesse de certas pessoas, mas não para outras. Uma organização adota muitas racionalidades porque a racionalidade é sempre baseada em interesses e pode mudar conforme a perspectiva adotada. Os profissionais geralmente usam a ideia de racionalidade como um recurso para atingir metas políticas, justificando ações que servem às suas aspirações pessoais em termos que pareçam racionais do ponto de vista organizacional. Na perspectiva política, a racionalidade surge como um mito social que as pessoas utilizam para mascarar ou superar a contradição de que uma organização é, simultaneamente, um sistema de competição e de cooperação. 
É possível perceber uma tendência pela busca por formas mais racionais de tomar decisões nas organizações, cujo intuito é inibir e reprimir comportamentos com enfoques muito pessoais que fujam aos interesses comuns. Os procedimentos para inibição desses comportamentos passam pela identificação da intenção dos atores e são legítimos à medida que ocorre a distinção entre o comportamento político funcional e o disfuncional. Isso porque, conforme se viu, os comportamentos políticos funcionais podem ser importantes para obtenção de conquistas significativas para a organização e, ao mesmo tempo, porque alguns profissionais utilizam um meio "aparentemente" racional para defenderem posições políticas que não necessariamente vão ao encontro dos objetivos comuns.

Para Bader (1991), no contexto das organizações atuais, o poder, o comportamento político, a competição e o conflito não podem ser vistos como sinistros, problemáticos, com contornos maquiavélicos, em que os fins justificam os meios. $\mathrm{O}$ comportamento político construtivo contribui ativamente para a mudança, o progresso, a tomada de decisão e a alocação de recursos, entre outras coisas, de modo que aboli-lo significaria secar a fonte da energia criativa. Dessa forma, o líder que não possua competências políticas para lidar com essa nova realidade estará irremediavelmente condenado ao insucesso, comprometendo os resultados organizacionais.

\subsection{Política e contexto}

A competência política é considerada um preditor de resultados organizacionais, como a performance no trabalho. Essa relação pode ser mediada por variáveis contextuais. $\mathrm{O}$ contexto determina como a competência política será utilizada. As pessoas com competência política sabem avaliar as situações e então se engajar em um comportamento adequado a um contexto específico que as ajudarão a alcançar seus objetivos (FERRIS; JUDGE, 1991). Nesta sessão, consideram-se o contexto nacional e portabto discutiremos alguns traços culturais brasileiros na descrição da cultura nacional. No entanto faz-se, nesta tese, uma breve discussão sobre o contexto de maneira geral na análise dos dados obtidos nas entrevistas sobre o ambiente político das organizações e também de forma específica sobre o contexto das organizações estudadas na apresentação dos estudos de caso.

Nesta pesquisa, tem-se o objetivo de verificar como a perspectiva política da liderança, especificamente a competência política, é percebida pelos profissionais 
brasileiros e pelas organizações que atuam no país. Para tanto, é necessário considerar o contexto brasileiro, ou seja, a cultura nacional. A maior parte da literatura utilizada nesta pesquisa foi desenvolvida com amostras estrangeiras, predominantemente anglosaxônicas. A cultura brasileira tem particularidades que podem ajudar na compreensão dessa percepção e da adequação desse tema à cultura das organizações brasileiras.

Segundo Motta e Caldas (2009), um dos fatores mais importantes que diferenciam a cultura de uma empresa da cultura de outra é a cultura nacional. Os pressupostos básicos, os costumes, as crenças e os valores, assim como os artefatos que caracterizam a cultura de uma empresa, trazem sempre marcas de seus correspondentes na cultura nacional. Para esses autores, não há como estudar a cultura das empresas que operam em uma sociedade sem estudar a cultura dessa sociedade. Mesmo que a globalização traga a tendência à uniformização de ideologias e comportamentos, por outro lado, toda sociedade, em maior ou menor grau, filtra ou adiciona seu próprio "tempero" a ideias e tecnologias globalizantes.

As empresas brasileiras são marcadas por decisões que tendem a ser caracterizadas por uma interação social intensa. A sociedade brasileira tende a ser mais nepotista no provimento de cargos ou de lugares nas organizações e no mercado de trabalho em geral. Os critérios de pertinência a determinado grupo social continuam sendo da maior relevância na luta por espaço organizacional ou social. Quando os brasileiros buscam construir uma rede de relações sociais pessoais no mundo do trabalho, acabam levando para o âmbito da racionalidade instrumental o terreno dos indivíduos, da afetividade, do mundo da casa, do pessoal. Personalizando as relações, elas sentem-se mais seguras e colocam em ação mecanismos de defesa como a identificação, a projeção e outros. O Brasil é visto como uma terra de contrastes, que ocorrem também no ambiente organizacional. O padrão tradicional passa ao moderno em ritmos diferentes em todas as regiões do país (MOTTA, 2009).

Freitas (2009) estabeleceu cinco traços brasileiros que ele considerou como mais influentes no âmbito organizacional: Hierarquia, Personalismo, Malandragem, Sensualismo e Aventureiro. Para fins de adequação ao tema apresentado, buscou-se caracterizar os traços de Hierarquia e Personalismo, por esses traços representarem como a sociedade brasileira lida com as relações sociais e as relações de poder e influência. $\mathrm{O}$ traço de Hierarquia está relacionado à tendência de centralização do poder dentro dos grupos sociais, ao distanciamento nas relações entre diferentes grupos sociais e à passividade e aceitação dos grupos inferiores. Uma expressão popular que representa 
bem esse traço é "Manda quem pode, obedece quem tem juízo". Já o traço de Personalismo indica que o país é uma sociedade baseada nas relações pessoais, em que as pessoas buscam proximidade e afeto nas relações. Já o paternalismo é o domínio moral e econômico do patrão. Esses dois traços mostram que a unidade básica no Brasil não é o indivíduo, mas a relação. Por essa razão, evitam-se soluções violentas dando preferência às conciliações e à amizade.

Segundo DaMatta (1985), o que vale no país é a malha de relações estabelecidas por pessoas, famílias e grupos de parentes e amigos. A relação perverte e cria variações da cidadania, hierarquizando e instituindo níveis de proximidade do centro de poder. $\mathrm{O}$ antagonismo que se apresenta nesses traços é a dificuldade de conviver em uma sociedade que é hierarquizada em suas relações, mas que, ao mesmo tempo, busca proximidade nessas mesmas relações. Para Prates e Barros (2009), a coesão social no Brasil está sujeita a uma ética pessoal que se manifesta pela lealdade às pessoas. O membro do grupo valoriza mais as necessidades do líder e dos outros membros do grupo do que as necessidades de um sistema maior no qual está inserido. $\mathrm{O}$ mecanismo de interligação entre os diferentes grupos de uma sociedade está centrado na pessoa, essencialmente nos líderes. A confiança é depositada na pessoa do líder, e ele passa a ser o elo que liga a rede, que integra os segmentos. Nesse sentido, o papel do líder será fundamental para que ele consiga que essa lealdade passe para o plano da identificação e imitação do líder. Esse fenômeno de fusão ampla e de "pertença" entre as pessoas envolvidas é um forte mecanismo de coesão.

Um estudo um pouco mais recente (CHU; WOOD JR., 2008) sobre os traços culturais brasileiros buscou descrever o estilo brasileiro de gestão em face das mudanças recentes nos contextos mundial e nacional. O estudo indicou que a globalização impactou a gestão das organizações no Brasil. Por meio da maior internacionalização dos negócios diante da abertura econômica e comercial, referenciais de gestão estrangeiros foram trazidos e incorporados às organizações locais, atuando como "modernizadores" da gestão praticada no país. Esse estudo permitiu observar que existem traços culturais nacionais que caracterizam e definem o estilo brasileiro de gestão que são marcantes - uns mais fortemente outros menos - e que são próprios da gestão das organizações no Brasil. Para esses autores, o estilo brasileiro de gestão está calcado, por um lado, em traços marcantes da cultura organizacional local e, por outro, nas transformações impostas pelas mudanças que ocorrem nos contextos nacional e internacional. Esse processo de transformação se caracteriza, concomitantemente, pela 
busca dos referenciais internacionais e pela grande consideração aos valores e necessidades locais, o que traduz o paradoxo da conciliação entre aquilo que é global com o que é local.

O estudo de Chu e Wood Jr., (2008) mostrou que os traços que se mantiveram foram: desigualdade de poder e hierarquia, flexibilidade, plasticidade, personalismo, gestão do tempo, autoritarismo, aversão a conflitos, postura de espectador e cordialidade. Já os traços culturais que têm passado por um processo de transformação ou ressignificação são: jeitinho, formalismo, orientação para resultados, orientação para a ação e planejamento. Os traços que se mantiveram mostram a manutenção do aspecto relacional e a força da hierarquia e das relações de poder na sociedade brasileira, que pode ser exemplificada pela distância entre alta e média gerência, pela valorização do status quo, pela acomodação das posições e pela dificuldade de dizer não. Por outo lado, manteve-se também a capacidade de adaptação e criatividade diante das mudanças. Os traços que passaram por uma ressignificação mostram um amadurecimento e uma maior profissionalização do trabalhador brasileiro, na medida em que foi demonstrada uma visão mais crítica, um foco maior no desempenho e a busca por planejamento.

A pesquisa de Chu e Wood Jr., (2008) mostrou ainda que, nesse contexto, o perfil do gestor estaria se alterando. É possível encontrar dois tipos de gestores atuando no mercado nacional, os executivos que possuem um referencial de gestão anterior à abertura econômica e um gestor de perfil mais atual. Esse perfil de gestor atual tende a ser mais cosmopolita, mais preparado profissionalmente, orientado a aspectos objetivos da gestão e mais focado em resultados. É importante ressaltar, no entanto, que esse gestor, apesar de estar orientado pelos referenciais estrangeiros e aberto a eles, é alguém que consegue, em geral, adequar o referencial internacional às necessidades locais, ou mesmo rejeitá-lo, ou seja, ele atua como um transformador da gestão praticada hoje em dia no país. Apesar das limitações do citado estudo em relação à abrangência e quantidade da amostra, ele permite identificar uma tendência de transformação ou novas nuances nos traços culturais brasileiros em razão das mudanças do contexto nacional e internacional. Essas novas nuances podem indicar novos caminhos, assim como transformações significativas e necessárias para adequação às mudanças nos negócios e na gestão das organizações nacionais e internacionais.

A ideia de abordar alguns traços culturais brasileiros tem o objetivo de possibilitar que esta pesquisadora tenha insumos para discutir questões que possam estar relacionadas ao contexto brasileiro, já que o presente estudo visa compreender como o 
tema da perspectiva política da liderança, especificamente a competência política, é percebido pelos profissionais e pelas organizações brasileiras. De maneira alguma esta sessão aborda a cultura brasileira na complexidade que lhe é própria; pelo contrário, sabe-se que a cultura brasileira apresenta traços complexos e, muitas vezes, paradoxais. Uma boa definição da ambiguidade da nossa cultura foi dada por CASTOR (2004), quando ele diz que o Brasil não é país para amadores.

Nas próximas seções serão abordados a perspectiva política e o comportamento político nas organizações, incluindo a perspectiva política positiva nos sistemas de carreira e liderança.

\subsection{O ambiente político das organizações}

Muitos autores concordam que o ambiente organizacional é, inerentemente, uma arena política (MINTZBERG, 1983; 1985; PFEFFER, 1981; FERRIS et al., 2000; JUDGE; BRETZ, 1994). Inicialmente, o poder nas organizações foi estudado como um tema isolado, sendo posteriormente associado às políticas organizacionais.

Segundo Miranda (2009), através da perspectiva política, as organizações deixam de ser vistas exclusivamente como um espaço de ação individual e coletiva decorrentes da autoridade formal hierárquica imposta por suas estruturas para passarem a ser vistas como territórios pluralistas, compostos e subdivididos por subunidades explicadas na base de objetivos e estratégias corporizadas nos comportamentos estratégicos dos atores. A interface entre as diferentes subunidades pode ocasionar competição, disputa e conflito, como resultado de subculturas, valores, lideranças e interesses distintos. Dessa forma, o conflito, que era percebido como uma patologia organizacional passa a ser interpretado como algo construtivo. As organizações são percorridas por uma delicada teia de interesses, propósitos, interações, negociações e compromissos entre os vários grupos internos (e externos), significando que quem tem objetivos são os indivíduos e não elas (FRIEDBERG, 1995). Nesse sentido, apresentase uma concepção ativa do indivíduo no contexto do grupo. Aliás, a expressão celebrizada por Crozier (1964) - ator organizacional - traduz essa ideia à perfeição, descrevendo um indivíduo no seio de um grupo, com objetivos, necessidades e anseios pessoais, cuja zona de ação concreta lhe confere trunfos para jogar o jogo do poder e da política. 
Nesta seção, as descrições de Bourdieu dos campos sociais (1968, 1989, 1996), as considerações de Mintzberg sobre as organizações como arenas políticas (1983, 1985) e de Morgan (1996) sobre as organizações como sistemas políticos serviram como base para descrever o ambiente político das organizações.

Bourdieu (1968, 1996, 1989) considera indissociável a análise das organizações e a análise social. Isso porque o espaço social no qual atores interagem constitui uma arena onde interesses distintos estão em disputa. Essa arena representa o campo do poder ou o espaço de relações de força entre atores providos de um ou alguns tipos de capital (cultural, econômico e/ou político). Esse autor desenvolveu uma filosofia da ação que trata da relação mútua entre os campos sociais (estruturas objetivas) e o habitus (estruturas incorporadas).

O campo social traz a noção do espaço de lutas ou jogos onde os atores sociais disputam o poder simbólico com o objetivo de impor sua própria visão de mundo e o fazem quando conseguem alterar a relação de forças a seu favor, valorizando sua posição no campo. O campo social é um espaço estruturado com suas próprias leis e regras de funcionamento, que não são explicitadas ou codificadas, mas que representam um conjunto de forças objetivas que são impostas a todos que entram na organização. Essas forças são irredutíveis às intenções de seus agentes individuais ou mesmo às suas interações diretas. O campo é uma estrutura de poder composta pela posição de seus atores em um determinado momento e pelas relações objetivas entre eles. O jogo gira em torno da conservação ou transformação da estrutura por meio da luta pela preservação ou pelo fortalecimento das posições.

Já o habitus é definido pelo conjunto de "ferramentas" simbólicas adquiridas pelos jogadores no campo político. O habitus são gestos, pensamentos, formas de estar que os indivíduos incorporam a ponto de não terem consciência deles. O habitus pode representar uma matriz de percepções, de apreciações e de ações, ou seja, um esquema transferido analogicamente, que permite resolver os problemas de um modo comum e que, portanto, representam as regras que estabelecem as disputas. Logo a lógica da ação dos atores sociais se estabelece na relação entre o campo (habitus coletivo), a posição que o ator ocupa (o quanto de capital ele acumula) e o seu habitus individual, que é estruturado ou estruturante. Essa relação de mão dupla é que possibilita o entendimento de que o habitus pode determinar essas posições, ao mesmo tempo em que essas posições o determinam. Para estabelecer-se em uma posição social de destaque em um campo específico, um ator social deve possuir o habitus particular daquele campo. 
Bourdieu (1968, 1996, 1989) defende que, para superar a dicotomia objetivismo versus subjetivismo, é preciso abandonar o pensamento substancialista que classifica os atores de acordo com as propriedades ou recursos diretamente perceptíveis à intuição e adotar um pensamento relacional que valoriza as relações invisíveis que se estabelecem no mundo social. Essas relações definem a posição relativa dos atores sociais (sejam eles indivíduos ou grupos) em relação aos outros que compartilham propriedades e recursos em determinado campo.

Os estudiosos das organizações que as consideram como sistemas sociais específicos dividem-se entre os que defendem que o conflito surge da dependência assimétrica ou desequilibrada entre as unidades organizacionais a respeito da tarefa, situando-o, portanto, no âmbito do trabalho na organização, e aqueles que localizam a base do conflito na estrutura de recompensas financeiras e de status social (CARVALHO; VIEIRA, 2007). O conflito é definido por Bobbio (1986) como uma forma de interação entre indivíduos, grupos, organizações e coletividade que indica choques para o acesso e a distribuição de recursos escassos. Para Morgan (1996), os conflitos podem ter três níveis: o pessoal, o interpessoal e o grupal. E, segundo ele, as fontes geradoras de conflito nas organizações podem ser: a estrutura organizacional, em particular na diferenciação vertical e de tarefas, os papéis organizacionais, as atitudes, os estereótipos e os recursos escassos.

Segundo Mintzberg (1985), as organizações são arenas políticas, o conflito está presente em parte ou em sua totalidade. As três dimensões básicas de um conflito nas organizações são: intensidade, penetração e duração/estabilidade. Poucas organizações conseguem sustentar um estado de conflito intenso. Conflitos intensos consomem muita energia, podendo ameaçar a organização e o cumprimento de sua missão. Para ser sustentável, o conflito precisa ser moderado em sua intensidade. Ao considerar as dimensões do conflito, o autor classifica quatro tipos de arenas políticas: 1) Confronto caracterizado por um conflito intenso, confinado e transitório. É uma forma típica de assumir o controle de uma situação quando, por exemplo, um influenciador externo tenta assumir o controle por meio do seu executivo principal; 2) Aliança frágil caracterizada por um conflito moderado, confinado e possivelmente durável/estável. Esse tipo ocorre comumente quando dois ou mais sistemas de influência ou centros de poder precisam coexistir de maneira igualmente equilibrada; 3) Organização politizada - caracterizada por conflitos que são moderados, penetrantes e, possivelmente, duráveis e estáveis. Nesse tipo de arena política, o conflito moderado penetra em todo o sistema 
de poder da organização, serve para descrever as grandes corporações, especialmente aquelas no setor público, onde os mandatos são visíveis e controversos; 4) Arena política completa - caracterizada por um conflito intenso, penetrante e instável. Essa forma de arena acontece quando influenciadores externos discordam entre si e tentam formar alianças com pessoas de dentro da organização, enquanto em conflito com outros. A arena política completa é a menos provável de ser encontrada na prática ou, pelo menos, a mais instável quando surge.

Três condições combinadas de várias maneiras fazem surgir a arena política. Uma pressão ocorre de um ou mais influenciadores para realinhar uma das coalisões ou para alterar a configuração de poder estabelecida. Outra condição comum é quando uma situação fundamental da organização precisa ser alterada, como a emergência de um novo e crítico corpo de experts, uma inovação ou uma séria redução de recursos disponíveis na organização. Essas mudanças, frequentemente, incitam alguns influenciadores a desafiarem a ordem de poder estabelecida para alinhá-la a nova condição. Algumas vezes, a ordem estabelecida de poder rompe por si mesma. A terceira condição é quando um chefe executivo adoece ou uma ideologia dominante enfraquece. Essa quebra cria um vácuo de poder, que os influenciadores tentam preencher. A maioria das transições de poder ocorre de maneira conflituosa e envolve resistência, e, normalmente, é a política que serve de "lubrificante" para possibilitar sua movimentação. Nenhuma distribuição de poder na organização, seja ela conflituosa ou não, é completamente estável no longo prazo e não está livre de ser desafiada (MINTZBERG, 1985).

A seguir, serão analisadas as organizações como sistemas políticos. Morgan (1996), no seu livro Imagens da organização, utiliza-se de metáforas para descrever o ambiente organizacional. Para esse autor, se as organizações forem examinadas com as lentes da política, os padrões de interesses, conflitos e jogos de poder dominam a cena. Nesse sentido, as organizações e sua administração são vistos como processos políticos, e o conflito como uma propriedade natural de toda a organização. A política é um aspecto inevitável da vida corporativa. Os dirigentes eficazes são atores políticos habilidosos que reconhecem o contínuo jogo entre interesses concorrentes e que usam o conflito como uma força positiva.

Para Morgan (1996), uma forma de diferenciação entre tipos de poder e comando pode ser realizada ao se recorrer a termos como autocracia e democracia para descrever a natureza de uma organização, que, na verdade, reflete de forma implícita o 
paralelo entre organizações e sistemas políticos. Esse paralelo ocorre também quando se refere às organizações como burocracias ou tecnocracias, isso porque se está, em cada um desses casos, caracterizando as organizações em termos de estilo particular de liderança política. Em cada uma dessas palavras, o sufixo cracia, que significa poder ou autoridade, é combinado a um prefixo que indica a natureza precisa do poder ou autoridade, empregado naquele ambiente. Esses ambientes podem ser: 1) Autocracias: organizações paternalistas ou firmas de família em que a autoridade de um indivíduo ou de um pequeno grupo é caracterizada pelo poder absoluto ou ditatorial; 2) Burocracias: o poder e a responsabilidade nessas organizações estão intimamente ligados ao conhecimento e ao uso das regras e à forma legal de administração; 3) Tecnocracias: nesse tipo de organização, o poder e a responsabilidade são influenciados pelo conhecimento técnico e tendem a acompanhar as pessoas com alto conhecimento; 4) Democracias: o poder de governar está na mão do demos ou da população. Esse poder pode ser exercido por meio de formas representativas de administração, em que os vários acionistas são formalmente representados, como nos sistemas de "codeterminação" ou governo de coalizão, e por formas de controle pelos trabalhadores ou pelos acionistas. No entanto o poder democrático pode ser exercido de forma direta, por meio de governos participativos, como as cooperativas. Enquanto nas autocracias e burocracias o padrão de poder e autoridade é bastante estável e bem definido, nas tecnocracias ele está em constante fluxo, na medida em que diferentes pessoas e grupos sobem e caem do poder. Nas democracias, o poder está baseado na cultura e nas ideologias que determinam a história política da empresa. É raro encontrar organizações que usem apenas um tipo de comando. Uma das tarefas da análise política da organização é descobrir que princípios estão em evidência e também onde, quando, por que e como. Segundo Morgan (1996), aqueles que defendem os direitos dos empregados ou a democracia industrial não estão introduzindo uma questão política, e sim propondo uma abordagem diferente para uma situação que já é política. A natureza política desses diferentes ambientes está baseada em diferentes princípios de legitimidade (MORGAN, 1996).

Ainda para esse autor, a política pode ser analisada nas organizações de maneira sistemática ao se focalizarem as relações entre interesses, conflitos e poder. A política nas organizações surge quando pessoas pensam de maneira diferente e desejam fazer as coisas de forma diferente. Essas tensões podem ser resolvidas de diferentes formas: nas autocracias, tem-se o "vamos fazer desse jeito"; nas burocracias, há o 
“devemos fazer desse jeito"; nas tecnocracias, usa-se o "É melhor fazer deste jeito" e nas democracias, o "como devemos fazer?"

Para Morgan (1996), a vantagem da metáfora política é o fato de ela permitir ver como toda atividade organizacional é baseada em interesses e permitir avaliar o funcionamento organizacional com isso em mente. O papel do poder na determinação de muitos aspectos da vida organizacional é, muitas vezes, ignorado. Nesse sentido, a administração do conflito torna-se uma atividade-chave. Os gestores devem reconhecer os diferentes interesses, objetivos e propósitos dos indivíduos e entender que os empregados provavelmente vão usar sua participação numa organização para fins pessoais. A administração concentra-se em equilibrar e coordenar esses interesses para que as pessoas possam trabalhar juntas dentro dos limites estabelecidos pelas metas formais da organização. Dessa maneira, os gestores são encorajados a reconhecer que o conflito e o jogo do poder podem servir tanto para propósitos negativos quanto para positivos e a encontrar formas de usar o conflito como uma força energizante. $\mathrm{O}$ conflito pode encorajar a autoavaliação e desafiar a sabedoria convencional. Pode causar certo grau de sofrimento dentro da empresa, mas pode também fazer muito para estimular o aprendizado e a mudança. Isso é particularmente verdadeiro nas situações de tomada de decisão em que a ausência de conflito produz conformidade e perda de eficácia. Ele facilita os processos de acomodação mútua por meio da resolução de diferenças, o que, paradoxalmente, pode, até certo ponto, servir para estimular a mudança e, outras vezes, para ajudar a manter o status quo. Uma das principais tarefas do gerente político é descobrir maneiras de manter o nível certo de conflito, já que muito conflito pode imobilizar a organização, mas muito pouco conflito pode encorajar a complacência e a letargia.

Outra vantagem da metáfora política, segundo Morgan (1996), é que, diferentemente das teorias organizacionais que são construídas sobre o pressuposto de que as organizações são sistemas unificados, ela aponta para as pressões e tensões desintegradoras que derivam dos diversos conjuntos de interesses sobre os quais a organização é construída. Se a realidade básica é a dos interesses diversos, a interação dependerá do grau em que as pessoas realmente precisam umas das outras. Nessas circusntâncias, é melhor pensar a organização como uma coalizão de interesses temporários e gerenciá-la dessa forma do que fingir que ela tem propriedades mais integradas. A metáfora política encoraja a reconhecer as implicações sociopolíticas dos diferentes tipos de organização e seus papéis societais. Essa metáfora traz questões 
como: "É possível ter uma sociedade democrática se a maioria das pessoas passa a vida de trabalho obedecendo a ordens de outras?" ou "As organizações devem poder participar da política como grupos de pressão tentando influenciar a legislação e outras diretrizes do governo?"

Por outro lado, Morgan (1996), discute também as limitações da metáfora política. Um ponto abordado por ele é que a política pode gerar mais política. Quando as organizações são entendidas como sistemas políticos, as pessoas começam a ver política em toda parte e a procurar intenções ocultas ou uma mentalidade cínica, egoísta e impiedosa mesmo onde elas não existem. Portanto, ao invés de usar a metáfora política para gerar nova luz e compreensão que ajude a lidar com interesses divergentes, geralmente, ela é reduzida a um instrumento a ser usado para promover os interesses próprios. Afirmações como "descubra onde está o verdadeiro poder e use-o" é um tipo de uso da metáfora que gera desconfiança e encoraja a ideia de que a organização envolve um jogo de soma zero. Por mais que isso possa existir nas organizações em razão da competitividade, mas que nega a existência de cooperações verdadeiras e da política como força construtiva na criação da ordem social e na reestruturação da relação entre organização e sociedade. Apesar de parecer amigável, a metáfora política pode subestimar as desigualdades de poder e da influência. Definitivamente, algumas pessoas têm mais poder do que outras. Existem múltiplas formas de poder que podem ser mais aparentes do que reais. A metáfora política pode exagerar o poder e a importância do indivíduo e subestimar a dinâmica que determina o que se torna político e como a política se manifesta.

\subsubsection{Percepção da política organizacional}

Uma área que tem ganhado atenção nos campos de pesquisa da política é a percepção da política nas organizações. Se três ou mais partes são envolvidas na política, o processo pode ser examinado sob a perspectiva de cada uma das partes. Ao adicionar a perspectiva da percepção, Ferris et. al. (1991, 1989, 2005, 2007 apud LEPISTO; PRATT 2012) possibilitaram o enriquecimento das pesquisas ao menos de cinco maneiras: 1) As ações políticas podem ser examinadas de diferentes posições de atores, dado um processo ou situação política; 2) É importante examinar não apenas como as pessoas em posições específicas veem e interpretam as ações políticas, mas também como elas percebem e atuam na presença de atores de outras posições; 3 ) 
pesquisas podem ser beneficiadas com a inclusão da percepção dos outros, mesmo que seja de situações ou atores de dentro, sobre a percepção de si mesmos; 4) Pesquisadores devem ser encorajados a investigar as ações individuais dos atores em diferentes posições; 5) Salientar a importância das várias posições no cenário político pode levantar questões relevantes sobre a intenção Na presente pesquisa, pretende-se avaliar a competência política não apenas por meio de autorrelato, mas também na avaliação de pares, superiores ou gestores de RH.

Um ponto importante sobre a habilidade de influenciar os outros é que ela baseia-se na percepção do alvo sobre o poder do ator, portanto, como o poder interpessoal é baseado em percepções, ele está sujeito à manipulação e a diferentes interpretações (TREADWAY et al., 2013).

A natureza ambígua e subjetiva dos processos organizacionais, como avaliação de performance, premiações, definições de salários e reconhecimento acabam motivando os profissionais a se engajarem em atitudes e táticas de influência. As táticas de influência servem como uma tentativa de mudar o julgamento daqueles responsáveis pelas tomadas de decisão, de maneira que esses alvos passem a ter uma visão mais favorável a seu respeito (KOLODINSKY; TREADWAY; FERRIS, 2007). O julgamento positivo ou negativo é baseado no estilo e competência do influenciador durante sua tentativa de influência.

Segundo Lepisto e Pratt (2012), a política nas organizações pode ser entendida como a ação de um ator ou mais atores (individual ou grupos) com interesse em uma meta direcionada, que utilizam comportamentos de influência social e poder em relação a dois ou mais atores sociais interdependentes, através de meios que não são oficialmente sancionados, com o objetivo de alcançar tal meta. Os atores apresentam diferentes posições nas ações políticas: o político ou aquele que inicia a ação política, como o Gerente; o eleitor ou alvo da tentativa de influência política, como o CEO; o público interessado ou alguém diretamente impactado pelo sucesso ou insucesso da ação política, podendo ser um aliado, como o Liderado ou um competidor, por exemplo, Gerente de um departamento diferente ou mesmo pessoas que talvez não tenham nenhuma participação direta na ação política ou espectadores, como trabalhadores de áreas distintas, mas que podem ser afetadas pela manifestação de um comportamento político na organização. Os indivíduos em cada uma dessas posições podem perceber e interpretar a mesma atividade política de maneira diferente (positiva, negativa e ambivalente) e responder diferentemente a ela. Ao considerar o papel da posição, é 
possível capturar plenamente a natureza social da percepção e interpretação da política na organização (LEPISTO; PRATT, 2012).

A percepção da política foi tratada em um estudo inovador à época por Ferris et al. (1989). Desde então, uma quantidade significativa de pesquisas foi realizada sobre a percepção da política. A percepção da política nas organizações pelos indivíduos foi associada a importantes efeitos nos resultados organizacionais, como: satisfação no trabalho, intenção de saída, cinismo, comportamento cidadão na organização. Ferris et al. (2002) alertam para a importância de compreender o lado positivo do comportamento político e para a expansão do conhecimento sobre a percepção da política.

A percepção do ambiente político é baseada em alguns fatos e características objetivas que influenciam a percepção e a forma como os indivíduos respondem a essa percepção. Fatores estruturais da organização podem levar à percepção de política, por exemplo, centralização e formalização, que foram considerados como antecedentes da percepção política. Empresas com falta de padronização de regras são percebidas como ambientes políticos em razão da subjetividade de suas normas. Para alguns autores, a ambiguidade presente nas organizações em razão da dependência e escassez de recursos é que cria o ambiente político propício para o comportamento político (FERRIS et al., 1989; FERRIS; HARRELL-COOK; DULEBOHN, 2000; FERRIS et al., 2002).

Algumas pesquisas mostraram de forma consistente que trabalhadores que têm oportunidades de promoção e uma boa interação com seus superiores são menos propensos a perceberem a política no ambiente de trabalho. Isso porque, tradicionalmente, a percepção de política baseava-se no comportamento político para fins de benefício próprio. Essa percepção de política foi associada ao aumento da tensão no trabalho e à diminuição da satisfação no trabalho (FERRIS et al., 2002; FERRIS et al., 1989). Recentemente, esses autores lançaram um programa de pesquisa que reconhece que poder e política são entidades passíveis de uma percepção sujeita a manipulação e interpretação. Nesse cenário de percepção, os indivíduos podem apresentar diferentes graus de habilidade de influenciar e entender os outros. Essa habilidade é conhecida como competência política (FERRIS et al., 2005).

Lasswell (1936) definiu a política como "quem consegue o que, quando e como". Essa foi a forma que esse autor encontrou para descrever uma das dimensões da influência social. Hoje em dia, a influência e a política são aceitas como fundamentais para todos os fenômenos sociais, incluindo o ambiente organizacional. Em um artigo 
recente sobre influência social e política, publicado com o título "O que sabemos e o que precisamos saber", na seção "Assuntos especiais" do Journal of leadership \& Organizational Studies, Ferris et al. (2016) dividiram o tema em três grandes áreas: Comportamento Político e de Influência, Percepção da Política Organizacional e Competência Política. A percepção da política nas organizações, segundo esses autores, envolve a avaliação de um indivíduo em relação à intenção de benefício próprio. Existem três categorias da percepção da política organizacional: 1) influência pessoal; 2) ambiente de trabalho; 3) influência da organização. A influência pessoal está relacionada às variáveis demográficas e características pessoais. O ambiente de trabalho, quando se torna mais competitivo em razão da escassez de recursos e da presença de restrições, tem sua ambiguidade aumentada. Outros últimos fatores que influenciam o ambiente de trabalho são autonomia, constância de feedbacks, variedade de habilidades requeridas, oportunidades de crescimento na carreira, atendimento às expectativas, adequação pessoa-organização e participação dos profissionais no processo decisório. Esses fatores reduzem a incerteza do ambiente e, por consequência, a percepção de política.

Uma série de estudos sobre a percepção da política identificou vários resultados da percepção da política nas organizações, como aumento do stress e intenção de turnover, baixa percepção de inovação e satisfação no trabalho, redução do comprometimento organizacional e da performance no trabalho e comportamento improdutivo. Embora haja uma aparente lógica de que a percepção política leva a comportamentos negativos dos empregados, sabe-se que a percepção do comportamento político é baseada no julgamento individual, portanto é possível que o resultado associado a tal comportamento determine a natureza da relação percepção do comportamento político e reação dos seus observadores (FERRIS et al., 1996; CHANG; ROSEN; LEVY, 2009; FERRIS et al., 2016).

$\mathrm{O}$ aspecto disfuncional da política está frequentemente associado ao olhar de quem vê, portanto a percepção ajuda a compreender os possíveis aspectos negativos do comportamento político. Pesquisas mostraram que a percepção da política organizacional está associada aos baixos níveis de comprometimento organizacional, satisfação no trabalho e baixa performance e, por outro lado, aos altos níveis de ansiedade no trabalho e intenção de deixar a organização. Uma pesquisa mostrou ainda alguns fatores que contribuem para a percepção de um ambiente político: a) ocupação de cargos em níveis mais baixos, falta de autonomia e falta de autoridade para tomar 
decisões; b) percepção do ambiente de trabalho com pouca formalização (regras e regulações); c) percepção negativa do clima e do ambiente de trabalho. Algumas variáveis relacionadas à disposição e a fatores pessoais também podem influenciar a percepção sobre política na organização, como características mais "maquiavélicas" e tendência de creditar problemas a fatores externos ao invés de pessoais. Outro ponto importante está relacionado ao feedback. Empresas onde os trabalhadores recebem mais feedbacks informais de supervisores e pares tendem a classificar o ambiente como menos político. Profissionais com baixa pontuação em relação a suas competências políticas tendem a apresentar sintomas depressivos em relação ao ambiente político da organização (DUBRIN, 2009).

Um estudo realizado por Fedor et al. (2008) mostrou que ambos os comportamentos políticos - positivo e negativo - representam percepções separadas tanto nos níveis individual, de grupo e organizacional. E, apesar de se esperar que o comportamento negativo fosse mais percebido, os achados na pesquisa identificaram que os membros da organização percebem tanto o comportamento positivo quanto o negativo e que ambos têm um papel na predição de reações dos empregados. $\mathrm{O}$ comportamento positivo foi associado a reações positivas, como satisfação no trabalho, com superiores e pares e preenchimento do contrato psicológico do trabalho com a organização (FEDOR et al., 2008).

A percepção da política na organização pode ser fortemente influenciada pelas práticas de Recursos Humanos da empresa. Os antecedentes da percepção mais influentes são a qualidade da relação líder-membro (LMX - Leader Member Exchange), o atendimento das expectativas, as oportunidades de avanços na carreira e a confiança nos pares. Por exemplo, oferecer uma expectativa realista aos candidatos durante o processo de entrevista, estabelecer uma comunicação transparente em relação aos papéis e responsabilidades, manter uma comunicação aberta sobre as oportunidades de carreira e a participação nas tomadas de decisão, com a criação de painéis e círculos de discussão, são práticas que podem aumentar o atendimento das expectativas e a qualidade da relação entre os membros da organização, consequentemente, uma percepção positiva do comportamento político (ATINC et al., 2010). 


\subsubsection{Perspectiva positiva da politica nas organizações}

A atividade política pode ser descrita como jogos. Os jogos políticos são intricados, sutis, simultâneos, sobrepostos, mas orientados por regras. Algumas dessas regras são explícitas, outras implícitas, algumas são claras e outras obscuras. Algumas são muito estáveis e outras estão em constante mudança. As principais razões para que os jogos aconteçam são: 1) a resistência à autoridade; 2) contrarresistência; (3) construção de uma base de poder; (4) destruição de um rival; (5) mudanças na organização. Os jogadores podem ser profissionais de todos os níveis e categorias, desde jovens profissionais da operação, passando por profissionais de nível tático até os mais altos executivos da empresa, podendo ser uma disputa entre pares ou entre diferentes níveis hierárquicos (MINTZBERG, 1985).

Para Mintzberg (1985), as organizações são capturadas pelo conflito e pela política, seja por completo, seja por uma parte significativa delas. O sistema político pode ser considerado um dos vários sistemas de influência nas organizações. Os sistemas de autoridade, de ideologia e de expertise podem ser descritos como sistemas legítimos em certo sentido. O sistema da autoridade está relacionado ao poder formal, alocado de forma explícita e sancionado legalmente. O sistema de autoridade tende a promover um único ponto de vista, normalmente aquele já estabelecido como favorável. Da mesma forma, o sistema de ideologia, apesar de implícito, tipicamente representa normas e crenças que são amplamente aceitas na organização, já que os assuntos são interpretados por meio do conjunto de crenças vigentes. O sistema de expertise representa o poder que normalmente se certifica em bases oficiais e sancionadas pelo poder formal. Ele é um sistema em que as pessoas tendem a submeter-se a um expert no assunto em questão. Já o sistema político, em contraste com esses sistemas, pode ser descrito de maneira a refletir um poder que, apesar de ser descrito como tecnicamente ilegítimo, talvez seja mais precisamente descrito como legítimo em seu significado e seus fins. Isso porque o sistema político encoraja uma variedade de "vozes" a ser ouvidas sobre um determinado assunto. Em razão dos ataques de seus oponentes, cada "voz" é obrigada a tirar suas próprias conclusões em relação às necessidades da empresa como um todo. Esse sistema parece servir para o atendimento do interesse da organização como um todo e não para interesses de um grupo em particular. O sistema político pode surgir quando os outros sistemas de influência estão ausentes ou fracos. 
Ele é frequentemente acionado para promover mudanças necessárias à organização e que estão bloqueadas por sistemas de influência considerados legítimos.

A relação com outros sistemas de influência pode ser pela coexistência, pelo antagonismo ou pela sua substituição. O conflito e a política podem estar presentes, mas não serem dominantes, como podem também ser o sistema de influência dominante, e o conflito forte pode enfraquecer os outros sistemas de influência. $O$ conflito que eventualmente captura a organização e dá início à arena política tende a ser circunscrito antes de se espalhar. O conflito pode não apenas ser moderado, como também contido. Isso porque duas alianças ou dois influenciadores poderosos não têm a intenção de destruir um ao outro. Eles tentam atingir um tipo de acordo implícito, silenciando o desacordo a fim de evitar que ele se espalhe ou para garantir que a organização sobreviva. O conflito pode ocorrer entre funcionários da organização, entre interessados de fora da organização ou entre esses dois grupos. O termo "influenciador" pode ser usado para descrever as pessoas que desejam afetar o comportamento da organização por meio da voz dos "influenciadores internos", essencialmente compreendidos pelos funcionários que dedicam seu tempo integralmente à empresa e que podem ser considerados a coalisão interna. Já os influenciadores externos são aqueles que têm o seu tempo comprometido com a empresa de maneira limitada e podem ser classificados como coalisão externa (MINTZBERG, 1985).

Mintzberg (1985) considera que o sistema político tem um propósito nas sociedades organizacionais. Esse autor discute os aspectos funcionais do sistema político. Para ele, não é necessário dedicar espaço aos aspectos disfuncionais da política nas organizações, afinal de contas, ela é divisionista, cara e queima a energia que deveria ser usada para alcançar a missão da empresa. A política disfuncional permite ainda aberrações e a manutenção de uma configuração de poder antiquada. O sistema político e a arena política devem ser interpretados por seus efeitos no longo prazo. O sistema político, se comparado aos outros sistemas de influência nas organizações, pode ser visto como necessário por corrigir as deficiências e as disfuncionalidades, já que proporciona certa flexibilidade que os sistemas de influência considerados, por alguns, como legítimos chamados legitimados de influência não permitem. Resumidamente, Mintzberg (1985) concluiu que esses sistemas de influência considerados legitimados, em muitos casos, são usados para fins ilegítimos. Em contraste, o sistema político, que, muitas vezes, é visto como ilegítimo, pode buscar alcançar fins legítimos. O sistema político pode agir de forma a selecionar os mais fortes e hábeis para as posições de 
liderança. Isso porque ele possibilita o acesso a canais alternativos de informação e promoção, impedindo que líderes fracos abafem subordinados fortes. Os jogos políticos servem também como testes na demonstração do potencial de um líder. Na competição, os jogos políticos mostram quem as pessoas são, contribuindo para a remoção dos mais fracos. Ele permite o debate, enquanto os outros sistemas promovem apenas um lado, e pode servir para corrigir uma mudança prévia e disfuncional de poder. O sistema político proporciona condições para as mudanças bloqueadas pelos sistemas "legítimos" de influência e facilita os passos para a execução de uma decisão. Os executivos mais experientes usam o sistema político para conquistar aceitação por meio da persuasão, da negociação e pela construção de alianças nas suas decisões. O sistema político serve também para acelerar a reciclagem ou a morte de uma organização dispendiosa.

É claro que um confronto político não corrige sempre uma situação, ele pode, inclusive, agravá-la. Pode servir de mecanismo de influência para aqueles que estão no centro do poder bloquearem as mudanças necessárias. No entanto é improvável que essa situação disfuncional permaneça estável no longo prazo. Alguns confrontos políticos podem ser arbitrários ou neutros. Um influenciador pode ter simplesmente o interesse por um novo acordo. Nesse caso, a arena política pode ser considerada disfuncional no período da duração do confronto, enfraquecendo a capacidade da organização de cumprir sua missão, que deve ser a de produzir bens ou serviços e não de criar uma arena para que as pessoas disputem o poder entre si. O resultado dessa disputa pode ser funcional ou disfuncional. Sem uma força que conduza a organização para uma resolução natural do conflito, esse conflito pode ser prolongado, enfraquecendo a organização. O exemplo típico é o da "Orquestra Sinfônica" nas alianças fracas, que deve combinar a existência de um maestro com autoridade e músicos com alta expertise. Esse exemplo não é arbitrário de modo algum, pelo contrário, ele demostra claramente a existência de diferentes centros de poder que precisam coexistir de maneira equilibrada. A existência da orquestra sinfônica reflete forças opostas na organização que são naturais, quase iguais em importância e irreconciliáveis, ou seja, a organização não poderia funcionar se ela não acomodasse cada uma dessas forças. Nesse caso, a ela não tem escolha a não ser a de formar alianças fracas. Esse modo de acomodar as forças pode não ser o mais eficiente, em um sentido estrito, mas é funcional. O conflito pode ser moderado ou pode ser inevitável para que a realização do trabalho seja possível (MINTZBERG, 1985). 
Para Bourdieu (1968, 1989, 1996), o jogo merece ser jogado, seja para conservação, seja para subversão da ordem. Para esse autor, se em um dado momento o campo social aparenta certa estabilidade e coerência que unifica a organização em torno de uma função comum, isso não significa autodesenvolvimento natural da estrutura, mas sim resultado de conflito e disputa dos atores. Ele ressalta, porém, que falar sobre poder, questionar como o poder é mobilizado por entre as estruturas organizacionais, não agrada àqueles que analisam as organizações. Carvalho e Vieira (2007), no seu estudo sobre o poder nas organizações, observam que todos parecem querer acomodar o conceito de poder inerente à burocracia de Max Weber, ou seja, aquele poder que trata da dominação, da habilidade de fazer que o outro faça o que se deseja que seja feito. Todavia o poder também pode ser conceituado como a capacidade de agir, que, no sentido dado por Hannah Arendt (2004), representa o poder como o exercício que impele à compreensão da política, que é, portanto, o agir entre os homens, a capacidade de promover a ação coletiva na construção de um devir. Para tanto, é preciso compreender que a administração e a política têm uma relação intrínseca e que o universo organizacional, nas suas várias dimensões, acontece entre os jogos de poder. Esse jogo não é o jogo de regras típico da burocracia, mas um jogo de forças em ação, em que os indivíduos estão em posição de exercer esse poder e, ao mesmo tempo, de sofrer sua ação.

\subsection{Comportamento político}

As áreas de estudos de política organizacional e comportamento político, apesar de serem intuitivamente relacionadas e representarem um fluxo consistente entre si, apenas recentemente foram integradas nas pesquisas organizacionais. Esses estudos demonstram que a percepção de um ambiente político leva ao comportamento político.

O comportamento político pode ser definido pelas atividades que não são formalmente exigidas por um cargo na organização, mas que influenciam ou tentam influenciar a distribuição de vantagens e desvantagens dentro da empresa (FROMAN, 1962). A política funcional está relacionada aos comportamentos que contribuem para a organização alcançar seus objetivos. Já uma política disfuncional impede que esses objetivos se concretizem (CROPANZANO et al., 1997).

O comportamento político é classificado de forma variada por diferentes autores. Burns (1961) descreve-o como uma influência não racional na tomada de 
decisão. Para Shell e Moussa (2007), ele é a persuasão estratégica, ou seja, a habilidade de conquistar as pessoas para o seu jeito de pensar e fazer as coisas sem utilizar esforços coercitivos. Para Mcintyre (2005), o comportamento político pode ser visto como o conjunto de qualidades interpessoais para efetivar a influência como inteligência política (MCINTYRE, 2005) e experiência política (DELUCA, 1999). Neste trabalho, utilizou-se o termo "competência política", cunhado no início dos anos de 1980, tanto por Pfeffer (1981) quanto por Mintzberg (1983). Para esses autores, a habilidade política é importante para navegação nas turbulências do contexto organizacional (FERRIS; DAVIDSON; PERREWÉ, 2005).

A política difere do exercício da autoridade ou de outro comportamento formal prescrito na organização (DRORY; ROMM, 1990). O comportamento político tem uma natureza informal, e as táticas de influência informais são consideradas como a dimensão principal da política nas organizações. As táticas de influência informais são tidas como direcionadas mais para as relações com superiores na hierarquia, no entanto Zanzi e O'Neill (2001) argumentam que as organizações com estruturas mais planas aumentaram o nível de política dentro delas de duas maneiras: reduzindo as possibilidades de influência nos níveis hierárquicos superiores e aumentando o papel da colaboração entre profissionais do mesmo nível hierárquico.

Para Sussman et al. (2002), atualmente é mais comum encontrar o comportamento político na colaboração entre pares do que nas interações verticais. A relação de troca entre pares refere-se à troca e às interações entre pessoas que se reportam a um mesmo supervisor. Apesar de os componentes de um grupo cooperarem por um objetivo comum e dividirem os louros de seus resultados, eles também participam de competições. Essas competições podem ser saudáveis ou não. Muitas empresas frequentemente incentivam uma competição para criar entusiasmo e camaradagem entre pares. A competição interna pode significar a proposta da melhor ideia para o aumento da qualidade ou para redução de custo. A relação positiva de troca entre pares é um ato político, no sentido de que aquele que inicia a troca sabe que isso aumentará sua relação com seus pares. $\mathrm{O}$ ator político, nesse caso, comporta-se de maneira ética e pratica a boa relação humana, mas ainda tem, de qualquer modo, uma motivação política (DUBRIN, 2009).

Miranda (2009) alerta para o fato de que, muito embora seja aparentemente notório o distanciamento e até o repúdio dos atores organizacionais no que diz respeito ao comportamento político e ao poder, sua interpretação não deve circunscrever-se aos 
seus aspectos negativos, sob pena de se obter uma visão simplista, falaciosa e redutora do fenômeno. Para tanto, essa autora cita duas investigações que bem retratam as contradições e ambivalências relativas ao poder e ao comportamento político. $\mathrm{O}$ primeiro estudo foi realizado por Gandz e Murray (1980) que entrevistaram 428 gestores. As respostas mostram que $90 \%$ dos inquiridos têm noção de que a política e os comportamentos políticos são uma realidade insofismável nas organizações; $89 \%$ afirmam existir uma relação de causa-efeito entre o sucesso do líder e a posse de competências políticas. Por outro lado, $59 \%$ dos respondentes concordam que a política interfere negativamente na eficácia e na eficiência organizacionais e quase $50 \%$ é da opinião de que as organizações deviam livrar-se do fator político. A segunda pesquisa mencionada por Miranda (2009) foi elaborada pelos autores Buchanan e Badham (1999) e os levaram a conclusões idênticas às do primeiro estudo. Ao procurarem aferir o papel do poder e da política em processos de mudança, verificaram que a maioria dos respondentes concorda com a ideia de que o líder que não tem competências políticas está irremediavelmente condenado ao insucesso. Os resultados mostram que 56\% atribuem uma imagem positiva ao gestor como um habilidoso "ativista político". Essa afirmação, de alguma forma, é contraditória já que, 53\% acreditam que a política é o equivalente à gestão danosa e incompetente, logo deveria ser erradicada, ao passo que $46 \%$ dos respondentes a veem como benéfica aos resultados organizacionais. Para Miranda (2009), essas contradições demonstram uma espécie de relação amor-ódio, em os indivíduos estão cientes da sua existência e da sua importância, são participantes ativos no jogo político, mas, ao mesmo tempo, defendem a sua abolição, já que a atividade é entendida como pouco transparente e que só algum são conhecedores das regras do jogo. Essa autora traz uma visão mais crítica dessa percepção predominantemente negativa, ao citar Farrell e Peterson (1982), que afirmaram que o desdém pela satisfação dos interesses pessoais encerra alguma hipocrisia em relação aos valores dominantes que gravitam em torno da bandeira do individualismo. Clegg e Hardy (1996), ao comentarem o estado da arte, lançaram a seguinte provocação: se são apenas os bad boys que fazem uso do poder e manifestam comportamentos políticos, então os good guys utilizam outra coisa qualquer que ainda não foi devidamente identificada e explicada.

Alguns autores defendem que a análise do comportamento político nas organizações deve focar as ações intencionais dos seus membros e reconhecer que algumas ações não intencionais ou idiossincrasias pessoais podem gerar consequências 
políticas. Apesar de não ser o foco primário, amizades e associações românticas, ocasionalmente, podem gerar consequências indiretas na política organizacional. E, finalmente, defendem que o poder individual, das unidades e da relação entre as organizações deve ser analisado sob a perspectiva política (PORTER; ALLEN; ANGLE, 1981).

O comportamento político pode ser utilizado tanto para o interesse pessoal como para o interesse organizacional. Muitos autores alertam para o fato de que esses interesses pessoais não são necessariamente opostos aos interesses organizacionais, pelo contrário, os objetivos pessoais podem contribuir para o alcance dos interesses organizacionais. Um gestor que utiliza o comportamento político para melhorar a sua reputação pode também aumentar a efetividade da sua liderança. O alcance dos objetivos pessoais não é sinônimo de comportamento político. Não é apenas o interesse pessoal de um profissional que pode fazer o comportamento político ameaçador para outros, mas sim o significado associado a ele. O esforço de profissionais em obter recursos e assumir posições-chave é frequentemente associado ao comportamento político. Porém os conceitos de racionalidade limitada mostram que a distribuição de recursos não é sempre baseada nas regras e regulamentações sancionadas e formais da organização, mas sim em agendas ocultas. O importante, segundo Muray (1980), é diferenciar o comportamento político que tem o foco na utilização da influência social ou da autoridade para a alocação de recursos daqueles comportamentos focados no interesse apenas pessoal e na ameaça ao alcance de metas de outros empregados da empresa (FEDOR; MASLYN, 2002; DRORY; ROMM, 1988; ULLAH; JAFRI; DOST, 2011).

O comportamento político dos profissionais envolve a utilização de várias técnicas de influência para alcançarem suas metas pessoais por meio da política organizacional. Várias nomenclaturas de táticas de influência foram encontradas na literatura relativas à política organizacional. Allen et al. (1979) encontrou oito formas frequentes de categorias de táticas de influência em seu estudo sobre comportamento político de gestores nas organizações: 1) atacar ou difamar os outros; 2) uso da informação; 3) gestão da impressão; 4) construção de suporte de ideias; 5) bajulação; 6) coalisões; 7) associação com pessoas influentes; 8) criação de sentimento de obrigação. Para Kipnis et al. (1980), as táticas políticas são: assertividade, bajulação, racionalidade, sanção, troca, apelo aos níveis superiores, bloqueio e coalisão. Vredenburgh e Maurer (1984) encontraram 11 táticas de influência: acumular e controlar recursos, barganha, 
formação de coalisões, formação de grupos informais, orquestrar eventos, manter uma flexibilidade pessoal, reduzir a dependência de outros, incutir dependência nos outros, envolver-se em conflitos, antecipar-se e preparar-se para as ações e reações dos outros, cultivar boas relações interpessoais, explorar outros e gerenciar a carreira. Para Ferris e Kacmar (1992), as táticas de influência encontradas foram: favoritismo, bajulação, sonegação ou distorção de informações, coalisões, gestão da impressão, pronunciação, trocas e reciprocidade.

Judge e Bretz (1994) identificaram que a bajulação e a autopromoção são as táticas de influência mais utilizadas pelos empregados. Zanzi, Arthur e Shamir (1991) identificaram uma lista extensa de táticas utilizadas por profissionais no ambiente organizacional: troca de favores, cooptação, uso de rituais e simbologias, manipulação, mentoring, oferecimento de cargos, persuasão, lidar com incertezas, intimidação, insinuações, controle da informação, táticas orientadas para as regras, uso de substitutos, construção de imagem, táticas de evasão de regras, networking, bajulação, metas superiores, oferecimento de recursos, uso da expertise, "carregar os outros nas costas", difamação ou ataque aos outros, uso de peritos externos e construção de coalisões.

Buchanan e Badham (2007), no estudo sobre envolvimento político de funcionários, apontaram que as principais táticas são: selecionar as informações, favorecer pessoas ou um grupo, evitar críticas, utilizar o apoio de pessoas-chave nas suas iniciativas, estimular debates, autopromover-se, utilizar-se de recompensa, coagir, ameaçar pessoas, culpar outros pelos erros, levar os créditos pelo trabalho de outros, usar outras pessoas para divulgar notícias ruins, ressaltar o erro de outros, comprometerse agora para ganhar mais tarde, fornecer informação errada, espalhar rumores e chantagear. Como é possível verificar, existe uma variedade enorme de táticas de influência que são utilizadas por empregados das empresas, muitas delas encontradas em diferentes estudos e, muitas vezes, sobrepostas. Outra observação importante é que, apesar de a maioria das táticas poder ser considerada disfuncional, existem também táticas funcionais, como estimular debates e construção de coalisão, que podem e devem ser utilizadas por empregados para alcançar objetivos organizacionais.

Para Wayne e Ferris (1990), as táticas de influência podem ser caracterizadas em três tipos, considerando os seus objetivos: foco no supervisor, foco no trabalho e foco em si mesmo. O sucesso no uso do comportamento político está relacionado à 
análise cuidadosa da situação para então definir o objetivo e o foco da tática adequada ao objetivo.

Pode-se considerar que o alto nível de política na organização se torna disfuncional quando a atividade política distrai o trabalhador e sua performance cai ou quando ele opta pela tomada de decisão mais lenta. A distração pode ocorrer quando uma pessoa se recusa a se engajar politicamente ou quando um gestor se concentra em disputas internas, deixando de focar a estratégia e a satisfação dos clientes (DUBRIN, 2009).

Apesar de, há décadas, o comportamento político ser foco de estudos organizacionais, a atenção maior sempre foi dada aos efeitos do benefício próprio para o líder do que ao impacto que esse comportamento pode causar em outros funcionários. A política é parte integrante da organização e, na realidade, de acordo com Hochwarter (2012), é o principal componente do contexto organizacional. O comportamento político pode proporcionar resultados muito positivos, como a resolução do conflito entre grupos e o suporte aos liderados (FERRIS; TREADWAY, 2012; HOCHWARTER, 2012). Obviamente, nem todo comportamento julgado como político é necessariamente ruim para a organização ou para os indivíduos envolvidos. Teóricos organizacionais têm defendido a importância de alinhar os objetivos pessoais com os objetivos da organização. Considerando essa perspectiva, o que pode fazer $o$ comportamento político positivo não é o aspecto do benefício próprio por si, mas a extensão em que o comportamento em benefício próprio pode ser visto como legítimo ou consistente com os objetivos e metas organizacionais (PFEFFER, 1992; KATZ; KAHN, 1978; FEDOR et al., 2008).

A visão funcional do comportamento político pode ser apoiada pelas premissas da psicologia positiva, que visa contribuir para o funcionamento saudável de pessoas, grupos e organizações por meio do fortalecimento das competências, ao invés de corrigir deficiências. Um dos objetivos da psicologia positiva é o equilíbrio entre os fatores positivos e negativos. A sua ideia não é negar o que é ruim, mas sim identificar as qualidades das pessoas e promover o seu funcionamento positivo. As organizações tendem a criar sistemas para lidar com eventos previsíveis e frequentes, porém muitos acontecimentos na organização acontecem fora do planejado, devendo ser abordados em meio a decisões em curso, quando os indivíduos precisam encontrar a melhor maneira de contribuir para a organização e ajuda-la a atingir seus objetivos e interesses no longo prazo. Segundo Seligman (2002), existem três pilares que sustentam o estudo da 
psicologia positiva, que são: o estudo das experiências subjetivas (as situações através da percepção do indivíduo); o estudo das características individuais (as características sentimentais reais de cada indivíduo); o estudo dos grupos e instituições (os meios nos quais o indivíduo está inserido). As experiências subjetivas tratam do bem-estar subjetivo de cada pessoa, ou seja, as satisfações, as emoções positivas, a esperança, o otimismo entre outros sentimentos. O estudo das características individuais abrange as pesquisas sobre a capacidade para o afeto, o perdão, a sabedoria e as habilidades interpessoais, que são os sentimentos de cada pessoa. Já o funcionamento dos grupos e instituições está relacionado à responsabilidade, à civilidade, ao altruísmo e ao trabalho ético (CONSTANTINO, 2011).

A ética na conduta das ações políticas também pode ser considerada uma diferença entre o comportamento político positivo e negativo. A questão da ética é um fator-chave da competência política das lideranças. O comportamento íntegro reflete uma característica que capta as percepções dos indivíduos afetados pela ação de que o ator mantém de forma consistente suas promessas e promulga os valores que defende. Em outras palavras, o comportamento íntegro captura a extensão em que os líderes falam o que eles querem realmente dizer, ou seja, o que tem significado para eles. Os líderes que são percebidos como dotados de alta integridade comportamental se comportam de acordo com suas falas sobre valores e intenções. Pesquisas mostram que os subordinados que sabem o que esperar de seus líderes tendem a confiar mais neles (SIMON, 2002).

Pesquisas têm demonstrado que a atividade política é maior em ambientes em condições de baixa formalização. As organizações atuais são caracterizadas por uma estrutura mais flexível, em que as regras, os regulamentos e os procedimentos são menores. Apesar de o comportamento político poder ser, às vezes, usado para o benefício próprio ou ser destrutivo, para que as organizações consigam sair de um status quo, esse comportamento não só é necessário, como é o único meio de proporcionar mudanças. Nessas circunstâncias, o comportamento político é funcional e é essa funcionalidade que caracteriza o comportamento político positivo (KATZ; KAHN, 1978; FERRIS et al., 2002; FEDOR et al., 2008).

Fedor e Maslyn (2002) entendem que o comportamento político pode ser considerado positivo quando é o único meio disponível para os membros de uma organização alcançar as coisas ou para levantar questões que as coalisões dominantes julgam inapropriadas em um período em particular. Na visão tradicional da política nas 
organizações, o comportamento político é percebido como não sancionado, porém ele pode ser benéfico para os seus atores, para o grupo de trabalho e para a organização. Um exemplo positivo pode ocorrer quando um grupo ou membro da organização chama a atenção para um problema que ela está enfrentando, mas que tem sido ignorado por sua cadeia de comando. O comportamento político positivo e o negativo podem ser considerados como comportamentos similares em sua forma, no entanto a maior diferença está em quem se beneficia dos seus resultados. No mesmo sentido, a abordagem da psicologia organizacional funcional prega que indivíduos podem se comportar - e se comportam - de maneira similar, porém por razões distintas (SNYDER, 1993).

\subsubsection{Motivações para o comportamento político (vontade política)}

Mintzberg (1983) foi, provavelmente, o primeiro autor a utilizar os termos "vontade política" e "habilidade política". Apesar de não ter apresentado uma definição formal, ele sugeriu que a vontade política representa a capacidade individual de expender energia em prol de um objetivo particular. Mais tarde, Treadway et al. (2005) descreveram a vontade política como a vontade de atores para expender energia para perseguir objetivos políticos, sendo esta vontade considerada um precursor essencial para se engajar no comportamento político (TREADWAY, 2012).

Recentemente, Treadway (2012) buscou aprimorar a definição de vontade política, revisando as forças que motivam o comportamento político nas organizações e buscando uma definição com uma perspectiva multidimensional. Em relação à motivação, esse autor se apoia no modelo de comportamento de influência de Leary e Kowalski (1990), que sugere que o nível da relevância do objetivo, o valor do objetivo desejado e a discrepância entre a imagem que o ator deseja projetar e a sua imagem atual são os três fatores básicos que levam um indivíduo a se mover para obter resultados sociais e materiais, manutenção da sua autoestima e desenvolvimento de sua identidade. Treadway (2012) utiliza também, como referência sobre motivação, o Inventário Multidimensional das Fontes de Motivação, de Barbuto e Scholl (1998). Essa escala trata das cinco bases da motivação: 1) Processo intrínseco: responsável por casos em que o trabalho é motivador em si mesmo; 2) Motivação instrumental: é o grau em que o funcionário percebe que seu comportamento o levará a resultados instrumentais ou tangíveis; 3) Autoconceito externo: motivação para agir em conformidade com as 
expectativas dos outros e para obter retorno externo que esteja alinhado ao seu autoconceito; 4) Autoconceito de necessidades internas: representa o padrão pessoal ou os objetivos que representam o ideal do indivíduo, motivando-o a agir em conformidade com esse ideal; 5) Objetivos internalizados dos funcionários: representa o nível em que o profissional está disposto a se engajar em comportamentos que estão alinhados aos seus valores pessoais.

Treadway (2012) concluiu que, apesar de os estudos sobre o comportamento de influência, especificamente sobre gestão de impressão, contribuírem para os avanços dos estudos sobre vontade política, eles apresentam uma visão limitada do fenômeno do comportamento político. Nesse sentido, esse autor criou seu modelo e sugeriu cinco dimensões da motivação da vontade política: 1) Instrumental: motivação relacionada aos aspectos econômicos e práticos. Na literatura, é normalmente associado ao interesse próprio, no entanto casos reais mostram que este não é o único fator determinante para uma pessoa se engajar na atividade política; 2) Relacional: apesar de não ter sido testada, a necessidade de pertencimento conduz ao comportamento político; 3) Preocupação consigo: trata-se da criação da identidade própria e da busca por compreender a si mesmo e como isso se relaciona com a sua capacidade e com o ambiente em que atua; 4) Preocupação com outros: apesar de menos tradicional no comportamento político, a preocupação com a melhoria de condição para os outros pode ser a motivação para que algumas pessoas se engajem no comportamento político; 5) Risco: a avaliação do risco pode comprometer tanto o alcance quanto a intenção de se engajar no comportamento político. Treadway (2012) propõe que, em qualquer situação, todos os indivíduos irão vivenciar a competição entre essas motivações e que o comportamento individual poderá ser previsto por meio da compreensão relativa da importância e projeção desses caminhos rivais.

\subsubsection{Determinantes do comportamento político}

Os fatores para o uso do comportamento político pelos empregados podem ser estruturais e individuais. Os fatores estruturais se referem ao contexto da organização, já os individuais são relacionados às características da personalidade. Os fatores estruturais mais comuns são: conflito aberto ou velado, desacordo em relação às metas ou estratégias da empresa, ambiguidade de papéis ou metas, processos e regras imprecisos, organizações burocráticas, centralização, incerteza, redistribuição de poder, 
disputa por território, disputa por um departamento ou profissional, cargos em nível gerencial, recursos escassos e, ao mesmo tempo, recursos abundantes que podem levar à desarticulação de metas (ULLAH; JAFRI; DOST, 2011).

Por outro lado, os fatores individuais mais frequentes são: busca por status, profissionais com necessidade de crescimento na carreira, profissionais com inclinação para riscos, e a principal determinante, que está relacionada às características da personalidade, que é a crença de alguns profissionais quanto a sua capacidade de controlar os acontecimentos na empresa, sendo esta determinante para o seu envolvimento no comportamento político. Existem dois tipos de personalidade: aqueles considerados controladores internos, cuja crença é que eles têm um alto nível de controle sobre os seus resultados pessoais, enquanto os controladores externos são aqueles que acreditam que suas vidas são controladas por forças externas. É importante salientar que o envolvimento de profissionais no comportamento político pode ocorrer tanto por determinantes estruturais como individuais ou por ambos os fatores (ULLAH; JAFRI; DOST, 2011).

\subsection{Competência política}

O comportamento político pode resultar em sucesso na carreira, preenchimento das necessidades de poder, alcance de status e de boa performance de líderes (ULLAH; JAFRI; DOST, 2011). Para Luthans, Hodgetts e Rosenkrantz (1988), apesar de a inteligência e esforço no trabalho serem parte determinante para performance, efetividade e sucesso na carreira, outros fatores, como astúcia social, posicionamento, experiência e habilidade, também representam um papel importante. Muitos pesquisadores reconhecem a existência e importância da política nas organizações, no entanto grande parte das pesquisas se concentrou nos tipos de estratégias e táticas utilizadas pelas pessoas no esforço de se comportarem politicamente. A busca pelo melhor entendimento sobre as características que possibilitam o exercício da influência para o alcance de sucesso foi o que motivou Ferris et al. (1999) a desenvolverem uma ferramenta inicial para a mensuração unidimensional da competência política.

Nesta seção, serão abordados o conceito, as dimensões, os antecedentes e a validade do construto da competência política, que é o construto-chave desta pesquisa e que trata de uma competência relacionada à efetividade social nas interações no 
trabalho. Trabalha-se nesta tese com a premissa de que a competência política é importante para a efetividade das lideranças nos seus cargos de gestão.

Diante da existência de várias definições sobre o conceito de competência, Dutra (2010) apresenta a construção de um conceito de competência que explica de forma mais adequada o que tem sido observado na realidade das empresas atuando no Brasil. Esse autor se baseia em estudos de autores como Le Boterf (1995, 1999, 2001 e 2003) e Zarifian (1996 e 2001): “o conceito de competência está associado à ideia de agregação de valor e entrega, em um determinado contexto, de forma independente do cargo, isto é, a partir da própria pessoa" (DUTRA, 2010, p. 46). Para ele, as empresas brasileiras mais bem sucedidas na gestão de pessoas têm aplicado, em conjunto, os conceitos de competência, complexidade e espaço ocupacional. A complexidade não está na situação em si, mas no que ela exige da pessoa, ou seja, a pessoa se desenvolve quando é capaz de realizar atribuições e assumir responsabilidades mais complexas. Dessa forma, a carreira pode ser compreendida pela sucessão de degraus de maior complexidade. Outro aspecto importante quanto ao estudo da complexidade é a observação de que a pessoa se qualifica para lidar com níveis de complexidade crescente.

Segundo Dutra (2010, p. 49), nos trabalhos realizados por Stamp (1989, 1993a, 1993b, 1994a e 1994b), "foi possível associar o nível de compreensão do contexto pela pessoa ao nível de complexidade com o qual ela consegue lidar”. Stamp (1989) chamou o nível de compreensão do contexto de "nível de abstração", que se ampliado quando o indivíduo enfrenta uma situação que exige mais. Quando ocorre a ampliação desse nível de abstração, isso permite que a pessoa possa enfrentar situações mais exigentes, portanto mais complexas, num ciclo de desenvolvimento. Já a expressão "espaço ocupacional" trata do conjunto de atribuições e responsabilidades das pessoas. Constatou-se que o espaço que as pessoas utilizam é dinâmico. Essa dinâmica do espaço ocupacional de uma pessoa na organização e sua demarcação é estabelecida, por um lado, pelas necessidades da empresa, do negócio ou do meio ambiente e, por outro, pela capacidade da pessoa de atender a essas necessidades (DUTRA, 2010).

Dubar (1998) entende que a competência não é um estado nem um conhecimento que se possui, pois a experiência cotidiana revela que pessoas que dispõem de conhecimentos e capacidades nem sempre sabem mobilizá-los em situações de trabalho ou em momentos oportunos. Em segundo lugar, esse autor reforça o caráter contingencial da competência, ou seja, ela é exercida em um contexto particular, 
exigindo flexibilidade e ampla capacidade de atualização, muito embora ele reconheça que a competência não é apenas um construto operatório, mas também um construto social. Assim, o indivíduo envolvido no processo de conhecimento ou de compreensão é guiado por sistemas de valores, de significações e por modelos que são socialmente compartilhados e que podem favorecer a competência, dificultá-la ou mesmo destruí-la.

Nesse sentido, Dutra (obra em fase de pré-publicação, 2017) considera que a realidade nas organizações atuais requer a discussão contínua de como lidar com recursos cada vez mais escassos, em um ambiente de crescente competitividade e em um cenário de incertezas e ambiguidades. Para esse autor, o gestor se distingue do líder por estar na arena política da organização. Segundo ele, muitas organizações reconhecem ter um bom gestor que é um péssimo líder. Isso porque, apesar de esse profissional ter uma capacidade de se articular bem na arena política, seja através da viabilização de projetos, seja pelo reconhecimento de pares e chefes, ele não sabe lidar com sua equipe de forma adequada. Nesse sentido, conclui que o grande desafio que se apresenta para as organizações é a escolha de futuros gestores que sejam vocacionados para atuação na arena política da organização e, ao mesmo tempo, sejam bons líderes.

Depois da consolidação da ideia de que funcionários precisam se engajar em atitudes e táticas de influência no contexto organizacional, pesquisadores buscaram compreender por que e como as táticas de influência são efetivas. Foi nesse contexto que a competência política foi introduzida na literatura de tática de influência. $O$ objetivo foi entender por que e como as táticas de influência são efetivas, as relações dessas táticas com os resultados organizacionais e quais estilos garantem o sucesso das entregas de resultados e da execução das táticas de influência. Desde então, o argumento de que os profissionais precisam de competência política e do uso da influência para alcançarem o sucesso organizacional tem se tornado cada vez mais forte e até mesmo parte da própria definição da competência política. A competência política é vista como a resposta para como e por que as táticas de influenciam são efetivas (FERRIS et al., 2016). Harris et al.(2007) argumentam que o porquê e o como as táticas de influência são efetivas estão relacionados às características pessoais do influenciador, como a sua competência política. O fato de os profissionais se engajarem em táticas de influência não garante o sucesso com o seu alvo. Kolodinsky, Hochwarter e Ferris (2007) reconhecem a competência política como o construto que aperfeiçoa a maneira, o estilo de apresentação e a execução da tática de influência para assegurar o sucesso da tentativa de influência. 
Na década de 1980, o construto "habilidade política" foi introduzido na literatura organizacional por Pffefer (1981) e, paralela e independentemente, por Mintzberg $(1983,1985)$. Esses autores advogaram a existência de um ambiente político nas organizações e a necessidade de o indivíduo ter vontade e habilidade política para obter sucesso e efetividade nas organizações. No entanto teorias e pesquisas sobre habilidade política permaneceram estagnadas, até o momento em que um grupo de pesquisadores orientados por Ferris et al. (1989), claramente influenciados pelo trabalho daqueles autores, resolveram desenvolver um programa de pesquisas desenhado para estabelecer mais informações e, consequentemente, uma maior compreensão desse conceito tão importante. O trabalho desse grupo de autores ajudou a dar suporte ao construto e a melhorar a compreensão do seu domínio e de suas implicações multidimensionais em razão dos vários estudos empíricos realizados. O objetivo era preencher uma lacuna causada pela omissão em relação à avaliação da competência política e à compreensão de por que alguns influenciadores são bem sucedidos ou não (FERRIS et al., 2005; FERRIS et al., 2012). Neste trabalho, utilizou-se o conceito de competência política desenvolvido por Ferris et al. (2005) nas suas quatro dimensões críticas - astúcia social, influência interpessoal, habilidade de networking e sinceridade evidente - como o conceito base para a pesquisa. Entretanto abordaram-se também os atributos individuais e as estratégias mencionadas por Pfeffer (1992) em seu livro Managing with power - politics and influence in organization, por se tratar de um autor que é referência no tema e como forma de ampliar a discussão, descrição e compreensão do conceito de competência política, visto que um dos objetivos deste trabalho é avaliar o entendimento e a adequação desse conceito na cultura nacional. Segundo Pfeffer (1992), ao tentar aplicar seus estudos em outro contexto cultural, é preciso cuidado para não importar, sem questionamentos, os indicadores que foram utilizados em outra cultura (nos Estados Unidos), mas, principalmente, é importante obter insumos que possibilitem uma discussão mais ampla, mesmo que alguns itens possam se sobrepor.

Pffefer (1981) concebe a competência política como uma característica individual que pode ser aplicada para demonstrar efetivamente o comportamento político a fim de adquirir e desenvolver um poder estruturado e determinado. Ele argumenta que a dinâmica entre poder, política e competência política ocorre na medida em que o poder reflete o exercício da influência, a política representa a tática empregada para desenvolver e adquirir poder e que a competência política proporciona a experiência e o conjunto de habilidades para alavancar recursos e executar o 
comportamento político que implicará a identificação do profissional por outros como poderoso. Para esse autor, a competência política é o melhor veículo para assegurar o poder nas organizações (PFFEFER, 2010).

Pfeffer (1992) descreve seis traços pessoais que são atributos relacionados com a capacidade de obter apoio e aliados, ou seja, de sobreviver em uma arena competitiva onde a interdependência é um fato: 1) energia e resistência física que está relacionada à habilidade de perseverar e ser um modelo de alta energia para lidar com as difíceis e longas tarefas; 2) foco, que é a capacidade de focar as energias e esforços, que são limitados, em uma direção; 3) sensibilidade a outros, que consiste na compreensão das pessoas, de seus interesses e atitudes. É a observação atenta que leva a uma melhor forma de se comunicar com os outros; 4) flexibilidade, no sentido positivo da palavra. Para esse autor, não basta ser sensível aos outros se o profissional não for capaz de modificar seu comportamento. A flexibilidade permite a mudança de abordagem para acomodar diferentes interesses; 5) habilidade de tolerar conflito, que reflete o entendimento de que no mundo social o conflito é uma constante e que é preciso vontade para se engajar nas situações de conflito e habilidade para superar as resistências; 6) submersão do ego e capacidade de lidar bem com as pessoas, em que o autor descreve a importância de saber mudar o comportamento de acordo com a necessidade da situação. Para ele, existem os momentos em que é importante entrar na "briga" e outros nos quais o interessante é construir alianças e redes de amizade para se dar bem com as pessoas; nesse caso, o ego deve ser ofuscado para se alcançar um objetivo maior.

Pfeffer (1992) relata também algumas estratégias que contribuem para uma interação social efetiva e para conseguir que as coisas sejam realizadas: 1) Saber lidar com o tempo - definir quando agir pode ser crucial para o sucesso e implementação de uma ideia. $\mathrm{O}$ autor defende que é preciso saber quando tomar a iniciativa de agir primeiro, quando atrasar, quando determinar um prazo ou mesmo esperar ou fazer com que os outros esperem. Escolher o momento propício e considerar a ordem das proposições pode influenciar os resultados; 2) Como usar a informação e analisá-la não há dúvida de que obter informação é fundamental, mas saber usá-la para encontrar uma resposta certa ou adequada para uma situação aumenta substancialmente o poder de influência de um profissional. O uso de processos racionais ou aparentemente racionais de análise ajuda a tornar o uso do poder e da influência menos óbvio. Decisões são mais bem aceitas se seguem procedimentos prescritos e legitimados. Quase todas as decisões 
envolvem não apenas a escolha entre as alternativas, mas a seleção do critério apropriado; 3) Mudar a estrutura para consolidar o poder - o agrupamento das posições e a alocação da responsabilidade no desenho da organização afeta sua eficiência. Alguns profissionais buscam se posicionar em unidades ricas em recursos e informações para se manterem em uma posição centralizada de grande influência. A criação de forças-tarefa e comitês é vista por alguns executivos poderosos como uma maneira de ter suas decisões tomadas ou ratificadas por conselhos ou comitês e, assim, evitar a aquisição de inimigos pessoais; 4) Atitudes simbólicas - as pessoas são persuadidas pela razão, mas movidas pela emoção. Os profissionais exercem influência por meio da linguagem, de símbolos, de cerimônias e cenários que fazem com que as pessoas se sintam bem em relação ao que elas estão fazendo É papel do gestor fazer com que as pessoas queiram fazer o que é preciso ser feito para a prosperidade da organização.

Mintzberg $(1983,1985)$ definiu as organizações como arenas políticas. Para ele, os influenciadores são caracterizados por aqueles que possuem alguma base de poder e também o interesse e a vontade de despender energia nessa arena para direcionar o esforço e as atividades de influência de maneira politicamente competente. Ele sugeriu que, para sobrevivência e efetividade nesse contexto, são necessárias vontade e competência política. A competência política significa a habilidade de usar as bases do poder efetivamente para convencer aqueles que têm acesso ao poder a utilizar seus recursos, informações e habilidades técnicas para negociação plena, exercitando o poder formal com sensibilidade ao sentimento dos outros, para saber onde concentrar seus esforços e energia, compreender o que é possível e organizar as alianças necessárias. Para esse autor, a competência política é um estilo e uma habilidade interpessoal podendo incluir charme, atratividade e carisma que contribuem para adaptabilidade em negociações, manipulação e persuasão.

Já para Ferris et al. (2005), a competência política é definida como a capacidade de entender os outros efetivamente e utilizar esse conhecimento para influenciar os outros a agirem de forma a aprimorar os objetivos pessoais e organizacionais. Atualmente, o conceito de competência política, ao contrário do que foi defendido por Mintzberg (1985), é um construto associado ao exercício da influência desprovida e independente do poder formal (PERREWÉ et al., 2004).

A competência política é um estilo interpessoal que combina a consciência social com a habilidade de se comunicar bem. É importante salientar que a competência política não é uma única habilidade ou traço. Preferencialmente, reúne habilidades que 
se reforçam mutuamente e refletem um conjunto integrado de componentes que seja consistente. Ferris et al. (2005) acreditam que a competência política é, em alguma extensão, inerente à pessoa, mas que pode também ser desenvolvida e moldada. Esses autores alegam que a competência política pode ser treinada, mesmo que uma pessoa não tenha uma propensão natural para isso. Não importa quão habilidosa seja a pessoa, se ela nunca trabalhar sua competência política ou ficar exposta a uma situação em que revele essa habilidade, ela não irá se desenvolver ou fazê-la acontecer. Esses autores citam várias formas de desenvolver essa habilidade, seja por meio da dramatização com ênfase no envolvimento emocional dos participantes, forma que é particularmente efetiva para a demonstração das diferentes maneiras que a competência política pode ser desenvolvida e praticada, seja pelo executive coach, que é uma técnica popular que ajuda os altos executivos a reconhecerem as situações políticas e aprenderem a desenvolver as estratégias efetivas para lidar com elas. Outros métodos efetivos citados por Ferris et al. (2005) são: sessões de feedback, filmagem da atuação de um papel, treinamento de lideranças, mentoring, modelagem comportamental e simulações de desenvolvimento.

O comportamento político é usualmente representado por algo imoral, com imagens relacionadas a ações nos bastidores, manipulação, comportamentos com finalidade de benefício próprio e favoritismo. Isso porque algumas pessoas utilizaram suas habilidades para mascarar abusos feitos em razão de posição e autoridade, porém competência política não é isso. Ferris, Davidson e Perrewé (2005) alertam que a competência política não é algo apenas para celebridades. Também não é algo simples, que uma pessoa utiliza para se livrar de problemas ou para prosperar pessoalmente por meio de esforços em benefício próprio à custa de outras pessoas. A competência política é uma característica efetiva e essencial, que, se aplicada da maneira adequada, pode fazer boas coisas acontecerem para os que a usam e para as organizações em que trabalham.

O conceito de competência política que traz uma perspectiva mais balanceada trata da criação de um ambiente em que a confiança e a construção de relacionamentos sejam a norma. Nesse sentido, a competência política verdadeira seria uma força positiva e essencial para o sucesso e a carreira nas organizações atuais. $O$ interessante desse construto é que as pessoas que têm essa habilidade aparentam não possuí-la, ou seja, as pessoas verdadeiramente competentes são percebidas como genuínas, autênticas e íntegras. A essência da competência política é a capacidade de influenciar os outros no 
trabalho por meio da persuasão, do suporte orquestrado, da confiança e da verdade. Para Fedor et al. (2008), a competência política pode ser utilizada tanto para resultados positivos quanto negativos. Eles afirmam que ela pode ser descrita como um conjunto de ferramentas para o comportamento político positivo, mas que não define sua adequação em seu uso.

Por outro lado, um grupo de estudiosos defende que a competência política é um atributo positivo. Para eles, os indivíduos politicamente competentes transmitem segurança pessoal, calma e autoconfiança que atrai outros e lhes fornece uma sensação de conforto. No entanto essa autoconfiança nunca chega ao ponto de ser confundida com arrogância, isso porque o indivíduo com essa qualidade tem o foco externo em direção aos outros e não autocentrado. Essa característica permite aos indivíduos politicamente competentes a manutenção do equilíbrio e da consciência que lhes assegura uma calibragem saudável em relação à responsabilização dos outros e de si mesmos (FERRIS et al., 2005). Conexões, amizades, alianças, construção de redes de relacionamento e coalizões são fatores críticos para os indivíduos navegarem na arena política das organizações e representam um aspecto importante da competência política (PFEFFER, 1981; BACHARACH; LAWLER, 1998).

A competência política é considerada uma competência de efetividade social desejável, que aumenta o alcance dos objetivos pessoais e organizacionais. Ela permite que o profissional gerencie os interesses divergentes de maneira que inspire consistência e positividade, aumentando o desempenho da gestão em contextos distintos a partir de vários assessores. Pesquisas empíricas confirmam as proposições de que a competência política tem uma relação forte e positiva com vários resultados desejáveis, tais como: crenças de autoeficácia, reputação pessoal, satisfação no trabalho, comprometimento organizacional, produtividade no trabalho e nas avaliações positivas de performance no trabalho (BLICKLE et al., 2011; MUNYON et al., 2015).

A competência política pode levar ao desenvolvimento e à aquisição de poder para influenciar outros e também pode resultar em reações positivas dos subordinados (TREADWAY et al., 2004). Ela se baseia na capacidade de ajustar o comportamento às demandas e nuances do ambiente e de situações particulares, contribuindo, dessa forma, para um comportamento mais flexível, necessário para lidar com as dinâmicas organizacionais da atualidade (FERRIS et al., 2000).

Durante a validação do Instrumento de Medição da Competência Política (Political Skill Inventory - PSI), Ferris et al. (2005) demonstraram que a competência 
política prediz a performance no trabalho e a sua efetividade, em duas amostras de um grupo de distintas ocupações. A competência política age como mediadora das táticas efetivas de influência e da performance.

Ferris et al. (2005) sugerem que pessoas competentes politicamente sabem não apenas diferenciar precisamente o que fazer nas diversas situações sociais no trabalho, mas também fazer isso de uma maneira que disfarce qualquer questão oculta, motivos de interesse próprio, aparentando sinceridade. Não obstante, esses autores não afirmam que os profissionais com competência política necessariamente possuem motivos de interesse próprio, mas que seu comportamento será o mesmo independentemente dos seus motivos ocultos. Segundo Cropanzo e Micthell (2005), a competência política pode ser considerada uma ferramenta, e sem essa competência uma pessoa pode ter atitudes absolutamente sinceras e devotas ao bem comum e as pessoas ainda duvidarem de suas intenções e se afastarem. Alguns autores argumentam que o comportamento político é uma simples extensão do interesse próprio do líder e que talvez seja possível dizer que o interesse próprio e o coletivo não sejam mutuamente excludentes (CROPANZANO; MITCHELL, 2005).

Os líderes com competência política se distinguem por três elementos centrais. O primeiro elemento consiste na capacidade de compreender facilmente os sinais sociais e identificar precisamente o comportamento e a motivação dos outros. $\mathrm{O}$ segundo permite ao líder influenciar e controlar pessoas e situações relativamente com pouco esforço. E o terceiro é a capacidade de construir efetivamente suas redes de relacionamento e seu capital social necessários para elevar seu status na organização e fornecer recursos escassos aos seus liderados. Esses elementos proporcionam ao líder habilidoso a capacidade de moldar suas ações de maneira genuína e sincera (FERRIS et al., 2003).

\subsubsection{Dimensões da competência política}

Após a realização de uma avaliação cuidadosa da literatura sobre a política na organização, com particular foco na competência política (mesmo que o termo não estivesse explicitado), Ferris et al. $(1999,2005)$ definiram alguns aspectos importantes que deveriam ser incluídos na mensuração representativa do construto "competência política". Conexões, amizades, construção de redes de relacionamento, alianças, construção de coalisões são aspectos críticos para os indivíduos navegarem na política 
nas organizações e representam um aspecto importante da competência política (FERRIS et al., 2005).

Esses autores indicaram quatro dimensões críticas da competência política: astúcia social, influência interpessoal, habilidade de network e sinceridade evidente. A astúcia social é a boa compreensão das interações sociais e a interpretação precisa do próprio comportamento e do comportamento dos outros. Indivíduos com essa habilidade estão profundamente atentos às diversidades sociais, são autoconscientes e observadores astutos. Trata-se da capacidade de entender os outros (seus sentimentos, desejos, personalidade, agendas ocultas). Diante disso, a pessoa consegue usar a forma mais adequada de se portar e se expressar para influenciar os outros. Os profissionais com astúcia social têm um grande poder de discernimento e autoconhecimento. A astúcia social se caracteriza como "sensibilidade aos outros", o que significa a capacidade de identificar-se com o outro, que é normalmente interpretada como ingenuidade ao lidar com os outros. Para Pfeffer (1992), essa característica é, de uma forma irônica, um meio crítico para conseguir obter coisas para si mesmo por meio da identificação com o outro (PFEFFER, 1992; FERRIS et al., 2005).

A influência pessoal permite às pessoas se adaptarem e calibrarem seus comportamentos em diferentes situações para extrair as respostas desejadas de outros. As pessoas com essa habilidade têm um estilo pessoal sutil e convincente exercendo uma influência poderosa sobre aqueles que os cercam. As características dessa habilidade estão relacionadas à flexibilidade, ao poder de adaptação e à capacidade de moldar o comportamento para cada situação. A flexibilidade contribui para a efetividade da influência por focar no objetivo principal, permitindo um afastamento emocional da situação. Os profissionais com essa habilidade aparentam ser pessoas agradáveis e boas para se associarem a elas. Apesar de esses indivíduos não serem sempre manifestadamente políticos, eles são vistos como líderes competentes, que apresentam um comportamento político justo e sem esforço (natural). Esse estilo político é interpretado mais como uma força positiva para a organização do que negativa. $\mathrm{O}$ profissional que tem a competência de influenciar pessoalmente as pessoas apresenta carisma e consegue se fazer querido. Essa habilidade está relacionada à habilidade e motivação de fazer as pessoas se sentirem confortáveis ao seu lado. Ele é dotado de estilo de comunicação efetivo, desenvolve boas relações, cria sinergia, foca um objetivo de caráter elevado. Usa essa habilidade para controlar o ambiente (PFEFFER, 1992; FERRIS et al., 2005). 
A habilidade de criar redes de relacionamentos na organização (network), segundo Luthans, Hodgetts e Rosenkrantz (1988), pode ser definida como um sistema de interconexões e cooperação entre indivíduos que é fortemente associado à dinâmica do poder e ao uso das competências políticas e sociais. Os profissionais com habilidade de network conseguem identificar, desenvolver e utilizar diversos contatos e redes de relacionamento, formando alianças fortes e benéficas. Esses profissionais estão sempre dispostos e sabem relacionar-se com os outros, são motivados a gastar tempo e esforço em desenvolver relações sociais no trabalho, criam relacionamentos formais e informais com pessoas que possam ajudá-los a realizar suas conquistas. Os relacionamentos são vistos como bens valiosos e necessários para o sucesso pessoal e organizacional. Cultivam amizades, constroem alianças e coalizões benéficas. Sabem se posicionar de maneira adequada e criam oportunidades. Eles são considerados bons negociadores, sabem fazer acordos e gerenciar conflitos, não de maneira manipulativa. Acabam conquistando as pessoas com quem se relacionam e ganhando a simpatia por suas ideias, acesso a informações, cooperação e confiança. São vistos como pessoas que têm a intenção de reciprocidade e inspiram comprometimento. Os indivíduos com essa habilidade conseguem se posicionar cuidadosamente para criar oportunidades vantajosas, tirar proveito delas e influenciar as decisões políticas. Pessoas com habilidade de criar redes de relacionamento se beneficiam do respeito e da simpatia das pessoas da sua rede, por exemplo, reações favoráveis às suas ideias, acesso às informações importantes e aumento da cooperação e confiança. Essas pessoas costumam saber quando solicitar ajuda e favores aos outros, são percebidas como pessoas dispostas a retribuir, conseguem inspirar comprometimento e um sentimento de obrigação daqueles a sua volta. Essa habilidade contribui para o aumento da reputação e capacidade de influenciar pessoas (FERRIS et al., 2005).

A perspectiva política busca explorar como o interesse, o poder, a estrutura oportuna, a definição de salários e o plano de sucessão contribuem para o desenvolvimento do sistema de carreiras nas organizações. Uma vez que o poder é derivado, em parte, do ambiente organizacional e é desenvolvido e exercido por meio da habilidade de network (redes de relacionamento), a perspectiva política foca sua atenção em fatores que ocorrem tanto fora quanto dentro da organização e nas características estruturais para as interações. Nas organizações atuais, o sucesso na carreira depende mais da competência política, que é a habilidade de influenciar, motivar e ganhar suporte de outros, do que de qualquer outra característica. Criar redes de relacionamento 
e interações com superiores, pares, subordinados, pessoas externas à organização é uma atividade política importante para uma liderança (FERRIS et al., 2000).

Já a sinceridade evidente reflete a forma verdadeira de executar a competência política. A sinceridade evidente representa a capacidade de aparentar sinceridade, genuinidade, integridade, autenticidade. Esses profissionais são ou aparentam ser honestos, abertos e francos e, consequentemente, acabam inspirando confiança e convicção. Apresentam interesse pelas outras pessoas. Essa dimensão da competência política foca a intenção percebida do comportamento em questão. A percepção das intenções e motivos é o que molda as respostas e reações e só será bem-sucedida se for vista como uma atitude sem objetivo obscuro. Profissionais com essa habilidade aparentam ser exatamente o que mostram, ou seja, o que se vê é o que ele é. A competência política é o que determina tanto a seleção das táticas de influência quanto à execução efetiva dessas táticas (FERRIS et al., 2005).

Pessoas com altas competências políticas conseguem expressar emoções de maneira genuina e convincente, seja por meio da comunicação eletrônica, do tom de voz ou de comunicações escritas. Indivíduos politicamente competentes são adeptos da construção de relacionamentos através da formação de conexões e do estabelecimento de fortes coalizões com outros. Profissionais com essa habilidade exalam um senso de segurança pessoal e autoconfiança que atrai outros e dão a eles um sentimento de conforto. A autoconfiança não chega ao ponto da arrogância e é utilizada no nível apropriado para ser considerado um atributo positivo, com o foco nos outros e não autocentrado (FERRIS et al., 2005).

A competência política proporciona ao indivíduo o sentimento de autoconfiança que inspira confiança nos outros e promove sua credibilidade. Resultados como avaliação positiva dos subordinados e aumento da reputação, índices de desempenho e promoção são creditados à competência política (TREADWAY et al., 2013). Para Farrell e Petersen (1982), o sucesso da gestão das atividades políticas é igualmente necessário para alcançar a efetividade organizacional. Em alguns casos, as atividades políticas são precondição para um comportamento administrativo racional. Alguns autores acreditam que a efetiva utilização das competências políticas torna-se cada vez mais importante para a carreira dos gestores (FERRIS et al., 2000).

A competência política é o estilo interpessoal que combina a percepção social ou astúcia com a capacidade de ajustar o comportamento de uma pessoa às demandas de 
situações mutáveis e diferentes de maneira a inspirar confiança, obrigação e genuinidade, influenciar efetivamente e controlar a resposta dos outros.

Para Kimura (2015), baseado na teoria da troca social, é possível inferir que, entre todas as dimensões da competência política, a astúcia social e a habilidade de network talvez tenham o maior impacto na efetividade da liderança do que outras dimensões. No entanto, na perspectiva da gestão da impressão, a influência interpessoal e a sinceridade evidente talvez sejam variáveis que tenham maior influência.

\subsubsection{Antecedentes da competência política}

Segundo Ferris et al. (2007), embora a competência política seja vista como uma competência que pode ser substancialmente moldada ou desenvolvida por meio do treinamento e da socialização, acredita-se que existam alguns dispositivos e habilidades pessoais que servem como antecedentes dessa competência. Ao considerar que a competência política é um estilo interpessoal que contribui para a efetividade nas interações interpessoais, os antecedentes de personalidade são aqueles que posicionam as pessoas no exercício da influência pessoal e no comportamento apropriado nas situações sociais no trabalho. Esses autores realizaram uma revisão sobre os estudos no campo da personalidade e utilizaram a estrutura de sistemas elaborada por Mayer em 2005. Essa estrutura trata de um sistema global do funcionamento psicológico do indivíduo. Mayer (2005) apud Ferris et al. (2007) sugere que o sistema de estrutura organiza a personalidade em quatro subsistemas: rede de energia, obras de conhecimento, ator social e executivo consciente. Em relação à competência política, o ator social é o subsistema mais relevante. Ele representa a expressão da personalidade por meio da adaptabilidade social. Isso inclui habilidade social, conhecimento do seu papel e expressões emocionais preferidas. Os traços principais no subsistema de ator social são a extroversão, que está ligada à amabilidade, e o automonitoramento, que se relaciona com a capacidade de percepção dos outros, de si mesmo e do ambiente. $\mathrm{O}$ subsistema do ator social serve como um dispositivo inicial que atua como antecedente do ator social orientado para dimensão da competência política (FERRIS et al., 2007).

Ferris et al. (2007) criaram um modelo que inclui os dispositivos antecedentes e pessoais da competência política. A FIG. 1, a seguir, representa esse modelo. 
Figura 1 - Antecedentes das dimensões da competência política

Antecedentes

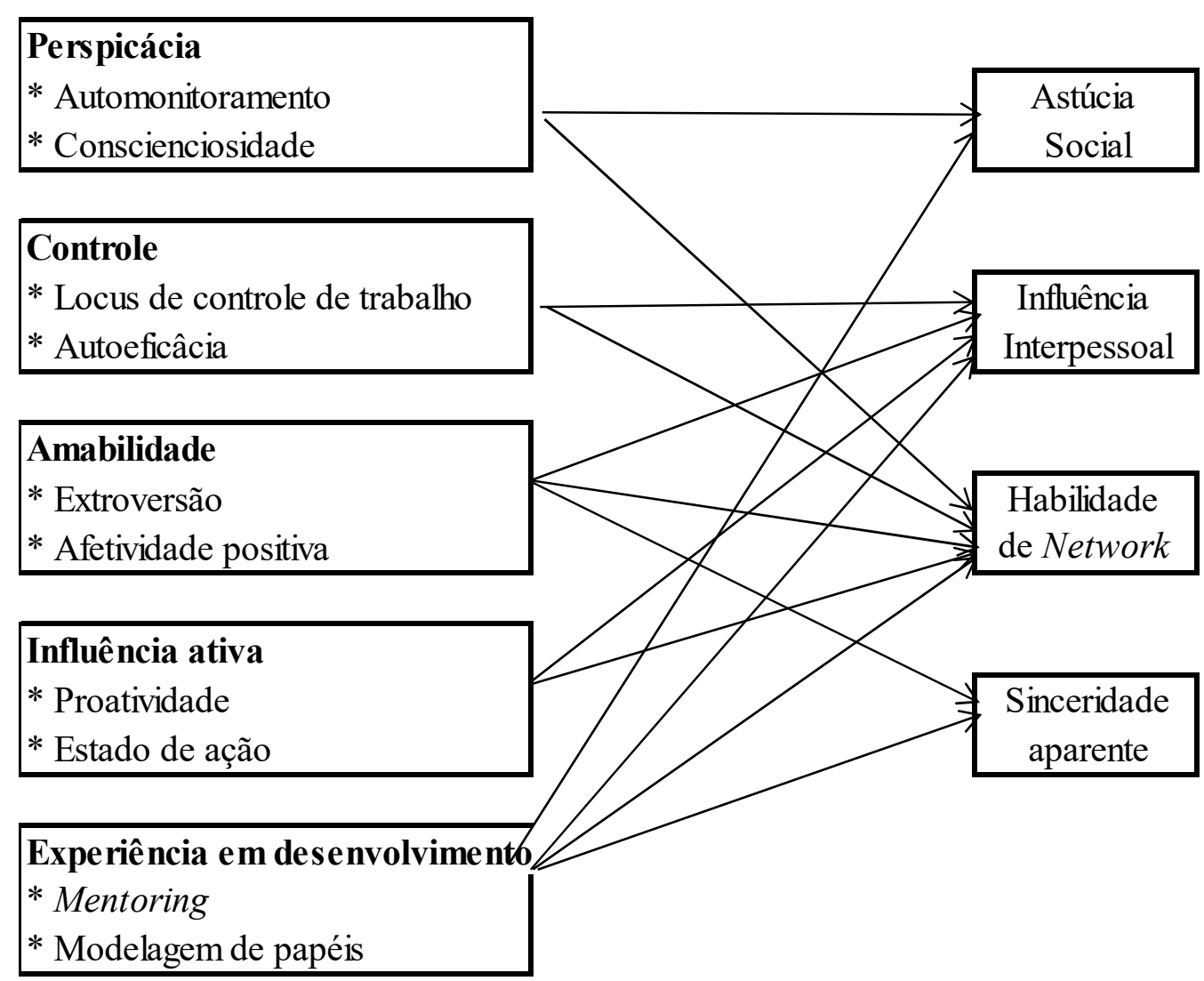

Fonte: Adaptado de FERRIS et al. (2007).

Nesse modelo, os autores ilustram construtos que refletem as dimensões da competência política. Perceptiveness (Perspicácia, discernimento) é a habilidade do indivíduo de monitorar e regular o seu próprio comportamento. É a capacidade de controlar a imagem que ele projeta socialmente. A conscienciosidade trata do fato de o profissional competente politicamente ser autoconfiante e, portanto, não ser autocentrado, ou seja, ele tende a manter seu foco para fora, em direção aos outros, e no ambiente, ao invés de em si mesmo. Estudos comprovaram que essas habilidades estão mais relacionadas à dimensão da competência política astúcia social, o que permite aos indivíduos a manutenção de um equilíbrio para calibrar de maneira saudável a prestação de contas de si mesmo e dos outros.

Control (controle e autoeficácia) refere-se a um dispositivo que trata da extensão na qual os indivíduos percebem controle sobre si mesmo e sobre o ambiente. $O$ locus de controle envolve as expectativas gerais de controle sobre recompensas e 
punições (locus interno) ou que as recompensas e punições podem ser controlados por outros através da sorte ou destino (locus externo). Já a autoeficácia refere-se a quanto um indivíduo acredita na sua capacidade de organizar e executar os cursos das suas ações para obter certos resultados, ou seja, um senso de controle e domínio sobre o ambiente. Esses dispositivos estão mais ligados às dimensões da competência política influência interpessoal e habilidade de network. A confiança em si mesmo faz com que a pessoa invista em atividades de influência. Essa confiança deriva da crença das pessoas sobre o controle pessoal.

Affability (amabilidade, afabilidade) é um aparato relacionado à extroversão, à simpatia e a uma orientação interpessoal agradável e de afetividade positiva. Esses dispositivos estão relacionados às dimensões de influência interpessoal, habilidade de network e sinceridade evidente.

Active influence (influência ativa) é um componente com grande orientação para a ação. Uma personalidade proativa apresenta uma disposição pessoal para desenvolver ações para influenciar o seu ambiente. A personalidade proativa identifica oportunidades e age mostrando iniciativa e perseverança. Já o estado de ação trata da diferença individual na habilidade de regular de maneira apropriada suas ações e cognições para alcançar suas metas intencionais. Uma pessoa com essa habilidade consegue filtrar o que é irrelevante, os impulsos competitivos ou pensamentos, permanecendo focado em atividades que facilitam o alcance dos seus objetivos. Essas habilidades estão mais relacionadas às dimensões da competência política influência interpessoal e habilidade de network.

Development experiences (experiências de desenvolvimento) lida com a questão de que a competência política pode ser aprendida e desenvolvida por meio de treinamentos efetivos. A competência política não está relacionada apenas à questão de traços de personalidade. Técnicas efetivas de treinamento podem oferecer aos participantes uma avaliação e um retorno sobre as suas interações sociais, seu grau de consciência quanto às situações sociais e quanto às várias alternativas de comportamento de resposta. As experiências de desenvolvimento, como a modelagem de papel e mentoring podem levar ao desenvolvimento das quatro dimensões da competência política. O comportamento de modelagem de papel trabalha com um expert demonstrando a maneira apropriada de se exercer uma habilidade particular como a competência política. Uma vez que essa competência foi modelada, a transferência através de treinamentos passa a ocorrer com a prática de repetição pelos 
seus participantes. O mentoring, por sua vez, é outra forma importante de desenvolver a competência política. Quando o mentor é um profissional talentoso e politicamente competente, ele irá demonstrar, por meio da sua linguagem, gestos, expressões faciais e postura corporal qual a melhor forma de exercer a influência. Como a política e a competência política são questões-chave no ambiente de trabalho, esse deveria ser o foco inicial na relação com o mentor.

Ferris et al. (2007) criaram ainda um modelo metateórico da competência política que inclui os processos intrapsíquico, interpessoal e nível de grupo. O processo intrapsíquico inclui práticas de desenvolvimento de recursos pessoais e objetivos pessoais. O processo interpessoal aborda práticas de táticas e estratégias de influência, posicionamento, networking e construção de coalizões. Já o processo no nível de grupo incorpora práticas de criação de visão, diagnóstico do clima do grupo e facilitador de interação do grupo, conforme mostra a FIG. 2, a seguir.

Figura 2 - Estrutura metateórica da competência política

\begin{tabular}{|c|c|c|}
\hline $\begin{array}{c}\text { Efeitos da competência } \\
\text { política na pessoa }\end{array}$ & $\begin{array}{l}\text { Efeitos da Competência } \\
\text { Política nos outros }\end{array}$ & $\begin{array}{c}\text { Efeitos da competência } \\
\text { Política nos grupos e organizas }\end{array}$ \\
\hline $\begin{array}{l}\text { Processo Intrapsíquico } \\
\text { * Desenvolvimento de } \\
\text { recursos pessoais }\end{array}$ & $\begin{array}{l}\text { Processo Interpessoal } \\
\text { * Táticas de influência } \\
\text { e estratégias }\end{array}$ & $\begin{array}{l}\text { Processo no nível de } \\
\text { grupo } \\
\text { * Estabelecimento de } \\
\text { uma visão }\end{array}$ \\
\hline * Objetivos pessoais & $\begin{array}{l}\text { * Posicionamento e } \\
\text { Network } \\
\text { * Construção de coalisão }\end{array}$ & $\begin{array}{l}\text { * Diagnóstico do clima } \\
\text { da equipe } \\
\text { * Facilitação da interação } \\
\text { dos membros da equipe }\end{array}$ \\
\hline
\end{tabular}

Fonte: Adaptado de FERRIS et al. (2007).

Essa estrutura mostra os efeitos da competência política para a pessoa, para os outros e para os grupos e a organização. Os efeitos da competência política para a pessoa estão ligados a dois processos intrapsíquicos que são (1) o desenvolvimento de recursos pessoais, que é o uso da habilidade de entender os outros para alcançar metas pessoais e organizacionais, e (2) objetivos pessoais, que são o produto das motivações do indivíduo. As pessoas desenvolvem metas, objetivos, motivações e esforços que guiam e abrem caminho para um comportamento no trabalho com foco no alcance das metas. Ferris et al. (2007) argumentam que os efeitos da competência política 
influenciam positivamente a autoavaliação, que, por sua vez, influencia positivamente as atitudes no trabalho e a redução do estresse e tensão no trabalho. Uma autoavaliação positiva resulta em uma maior confiança e segurança do trabalhador e traz uma percepção de domínio e controle do ambiente de trabalho e uma neutralização do estresse.

Já os efeitos da competência política nos outros estão ligados aos processos interpessoais que são: 1) as táticas e estratégias de influência que se referem à capacidade do indivíduo com competência política de selecionar um tipo particular de tática ou estratégia de influência, por exemplo, a assertividade, manter uma flexibilidade pessoal, reduzir a dependência de outros, a ser empregada em cada situação; 2) o network e posicionamento, que estão relacionados, respectivamente, à vantagem de possuir uma rede social com contatos heterogêneos, estrutura aberta e um papel estruturante que liga indivíduos não relacionados e o posicionamento, que é considerado um fenômeno no nível individual. O posicionamento descreve a relativa colocação do líder entre outros indivíduos, direciona a localização física, psicológica, econômica e o “espaço político" para realização de acordos e negociações; (3) a construção de coalisão, que está intuitivamente relacionada à capacidade de criar redes de relacionamento, o que aumenta o poder de influência. A construção de coalisões coloca pares e subordinados a apoiarem e reforçarem uma posição tomada ou um recurso solicitado. Isso fortalece o resultado obtido pelo apoio de um número de pessoas maior. Pode-se concluir que a competência política tem um efeito nos outros na medida em que altera a impressão que elas têm dos indivíduos politicamente competentes. Essa competência proporciona aos indivíduos uma calma e um senso de autoconfiança que inspiram confiança e segurança e que promovem credibilidade. Outra vantagem dessa competência é a adaptabilidade, que é cada vez mais necessária e valorizada no ambiente organizacional. O comportamento apropriado, a identificação das diferentes situações contribui para uma melhor autoapresentação, o que melhora a reação das pessoas, a construção de capital social, a reputação, a avaliação de performance mais alta, as oportunidades de promoção e permanência no trabalho, o que, em última instância, significa o aumento do poder de influência.

Por último, Ferris et al. (2007) tratam dos efeitos da competência política nos grupos e na organização. Muitas organizações têm utilizado uma estrutura baseada em trabalhos em grupo. E as pesquisas corroboram a importância do comportamento do líder para a performance do grupo. Isso porque líderes nas organizações 
contemporâneas precisam focar suas energias em atributos interpessoais da liderança como coaching, coordenação e orquestração. A competência política dá ao líder a astúcia social e a flexibilidade de comportamento indispensáveis para direcionar as necessidades e motivações dos seus empregados. Esses autores discutem três atitudes que a liderança competente politicamente estabelece para conseguir bons efeitos no nível de grupo: 1) estabelecer uma visão se refere à formulação e articulação da visão, que é um símbolo de possibilidades e de uma destinação atrativa e credível de futuro, criando significado compartilhado e identidade comum, oferecendo desafios e energizando a empresa; 2) diagnosticar o clima do grupo, que é uma variável que afeta o sucesso do grupo. Para acessar e diagnosticar o clima do grupo, os líderes precisam de perceptividade e de um relacionamento efetivo com os membros do grupo. A competência política contribui para melhor compreensão e diagnóstico desse clima, uma vez que o líder com astúcia social consegue acessar de maneira cuidadosa as áreas de concordância e a percepção comum dos seus membros; 3) facilitar a interação entre os membros do grupo, que é uma maneira de os líderes contribuírem para a performance e efetividade da unidade, o que se dá através da habilidade do líder de coordenar, orquestrar e facilitar a interação do grupo de maneira produtiva. Para tanto, é preciso competência política para apoiar os liderados, mobilizar e inspirar as pessoas a perseguirem e alcançarem as metas-chave da organização, já que um papel fundamental das lideranças é eliminar as barreiras que possam impedir a efetividade do grupo e moldar o comportamento do grupo na direção apropriada.

\subsubsection{Validade do construto "competência política"}

A competência política é um construto que se sobrepõe a alguns traços de personalidade e a outros construtos relacionados à efetividade social. Ferris et al. (2005) acreditam que a competência política é um construto distinto e suficientemente diferente de outros. Resultados preliminares mostraram evidências da validade do construto. No entanto Ferris e Treadway (2012) argumentam que a teoria e a pesquisa desenvolvida com os rótulos tática de influência, gestão da reputação, poder, influência entre organizações, política nas organizações tendem a refletir mais aspectos comuns do que diferenças com a competência política. A distinção maior dos vários conceitos está na percepção imoral e de benefício próprio comumente identificados como um comportamento político. Apesar de a criação do termo "competência política" contribuir 
para a distinção e a ampliação do conceito, ainda assim é um construto similar aos demais, que falsamente assume que os atores e observadores serão capazes de precisar as intenções dos outros e de si mesmos.

Ferris et al. (2002) discutiram sobre a proliferação de construtos sociais (habilidade social, competência política, inteligência social etc.) e sobre a necessidade de delinear precisamente o caráter único de cada um deles. Eles argumentam que esses construtos têm em comum uma compreensão cognitiva e um componente de percepção, além das ações comportamentais, usados para agir sobre o conhecimento anterior, mas que são reflexos de um construto de uma ordem maior referida como "efetividade social" (FERRIS et al., 2005).

Os trabalhos iniciais sobre inteligência social foram fundamentados em várias medidas de efetividade social, como automonitoramento, empatia e até mesmo competência política (AHERAN et al., 2004). Apesar de haver uma sobreposição inerente desses construtos, pesquisas empíricas conseguiram diferenciar a competência política de outros construtos similares de efetividade social, especialmente os estudos de Ferris et al. (2005), que forneceram suporte para a validade convergente que distingue competência política de automonitoramento, experiência política, habilidade mental geral (GMA) e inteligência emocional (Ferris et al., 2016). Da mesma forma, estudos anteriores contribuíram para o suporte da validade convergente ao reportar que a competência política estava apenas moderadamente relacionada com afetividade positiva, extroversão, empatia, conscientização, compreensão dos eventos e atraso da gratificação. Estudos adicionais encontraram validade discriminante entre a competência política e a habilidade mental geral (GMA), uma vez que seus estudos falharam em encontrar relação significativa entre esses construtos (FERRIS et al., 2016).

O construto experiência política sugere adaptação às nuances da política nas organizações e pode ser determinada pelos componentes: conhecimento e/ou compreensão e que inclui uma capacidade implícita de agir com esse conhecimento. Esse construto pode ser relacionado positivamente e, provavelmente, de maneira significativa com a composição da mensuração da competência política. Já a inteligência emocional é um construto amplo que poderia ser interpretado como redundante em relação à competência política. A inteligência emocional recebeu muita atenção na década passada em razão dos best-sellers de Daniel Goleman (1995,1998). A inteligência emocional tem seu enfoque voltado para os aspectos emocionais da 
efetividade interpessoal, da influência e do controle. Por outro lado, a competência política incorpora o conhecimento e a habilidade que vão além das emoções. É possível considerar uma relação positiva entre a inteligência emocional e a competência política, mas não a ponto de considerá-los construtos redundantes ou sobrepostos (FERRIS et al., 2000; FERRIS et al., 2005; FERRIS et al., 2012). Estudos mais cuidadosos das pesquisas científicas sobre a inteligência emocional indicam que o foco predominante é baseado nos aspectos emocionais da efetividade interpessoal, da influência e do controle. A concepção de Goleman $(1985,1998)$ de inteligência emocional é ampla e inclui quase tudo, exceto a habilidade mental geral e a inteligência.

A competência política não é um simples sinônimo de tática de influência e não está relacionada à assertividade. Ela é um estilo e é positivamente correlacionada ao automoritonamento (que é a extensão na qual uma pessoa está consciente do ambiente e sensível às pistas interpessoais) e à conscienciosidade (que é a extensão na qual uma pessoa está atenta aos prazos e encontra as melhores soluções para os problemas no trabalho). A dimensão astúcia social, entre as quatro dimensões da competência política, foi a que apresentou maior correlação com automonitoramento e conscienciosidade. A competência política é inversamente relacionada à ansiedade geral, no sentido de que uma pessoa competente politicamente está apta a experimentar menos stress e tensão do que outra menos habilidosa.

A competência política se diferencia empiricamente de outros construtos similares relacionados à efetividade social, como a habilidade cognitiva. Ela não depende da perspicácia mental, no entanto a habilidade cognitiva e a competência política podem acontecer juntas, mas também pode ocorrer de uma pessoa possuir alta competência política sem ter um alto índice de QI.

Alguns estudos evidenciaram a não redundância entre a competência política e táticas de influência, no entanto a competência política está relacionada a algumas táticas de influência em particular, como o apelo aos superiores, que é a obtenção de suporte dos indivíduos em posição hierárquica superior, e a coalisão, que é a tática para conseguir suporte dos pares e subordinados de maneira a reforçar a posição alcançada e a aquisição de recursos (FERRIS et al., 2005).

Ferris et al. (2007) admitem a necessidade de examinar a relação entre alguns construtos, principalmente entre a competência social e a competência política. Essa distinção é crítica porque os dois construtos, às vezes, são usados de forma intercambiável. Estudiosos nessa área argumentam que a competência social e a 
competência política são construtos distintos. Para Peled (2000), a competência social é a facilitação e o conforto da comunicação entre líderes e seus liderados, pares, superiores e clientes. Já a competência política refere-se à habilidade do gestor de manipular suas relações interpessoais com os liderados, colegas, clientes e superiores para assegurar o sucesso final do projeto. Pesquisas futuras precisam ser empiricamente validadas a respeito dessa distinção (FERRIS et al., 2007).

Como se pode perceber, o construto "competência política" ainda passa por um processo de consolidação e diferenciação de outros construtos relacionados à efetividade social ou à sensibilidade interpessoal. Alguns estudos citados acima mostram que foi possível diferenciá-lo empiricamente de alguns construtos e, em outros casos, ainda existe uma demanda por mais pesquisas para estabelecer a real fronteira entre eles. No entanto justifica-se a escolha e utilização do termo "competência política", em detrimento de outros construtos de natureza social, por ele abordar também o aspecto político no contexto organizacional, o que não está presente ou explicitado nos demais construtos de efetividade social.

Chao et al. (1994) identificaram uma dimensão da socialização na organização que foi chamada de política. Em uma avaliação mais profunda dessa dimensão política, descobriu-se que se tratava da mensuração da experiência política ou do entendimento político, por meio de questões como: "Eu aprendi como as coisas 'realmente' acontecem nas organizações"; "Eu sei quem são as pessoas mais influentes no ambiente de trabalho"; "Eu tenho um bom entendimento dos motivos por trás das ações das pessoas na organização". A experiência política e o entendimento político são aspectos fundamentais para lidar com a política nas organizações. Ferris et al. (2005), na criação do Political Skill Inventory (PSI) sugeriram uma relação entre a dimensão astúcia social e a experiência política, o automonitoramento e a conscienciosidade.

Por essa razão, acredita-se que a questão política abordada por esse construto é fundamental e um diferencial significativo em relação aos demais. Não basta saber lidar bem com as emoções e as pessoas para obter a efetividade na "arena política" da organização. É preciso entender as nuances do ambiente político para utilizar esses conhecimentos, essas habilidades e atitudes. Outra justificativa para a utilização desse construto está relacionada ao seu aspecto positivo, que se refere à efetividade organizacional, ou seja, à efetividade social utilizada no ambiente organizacional, onde não cabe o objetivo apenas para o benefício próprio; é preciso que ele esteja relacionado e em harmonia com um objetivo organizacional. A competência política é, portanto, um 
termo que se considera, neste trabalho, mais completo, mais realista e até mesmo menos inocente do que os demais, em razão dessa perspectiva política.

Para Lepisto e Pratt (2012), a identificação dos elementos principais da política contribui para a diferenciação desse construto de construtos similares, aumentando sua utilidade teórica. Segundo esses autores, alguns construtos, por definição, são subconjuntos de outros construtos, mas o inverso nem sempre é verdadeiro. Embora toda política na organização vá envolver poder e influência, nem toda ação de poder e influência envolverá política. Além do mais, a política na organização é um construto que abarca condições necessárias múltiplas, mas não condições suficientes. Outros construtos podem ter alguma condição, mas não todas as condições necessárias. Por exemplo, algumas características diferenciam o construto “gestão de impressão" de política. A gestão de impressão engloba a influência social ao melhorar a atratividade de uma pessoa para criar um sentimento de afeto. Apesar de a gestão de impressão desempenhar um papel similar ao poder e à influência social, a política sempre abarca algum tipo de gestão de impressão, no seu conceito amplo, no entanto nem toda gestão de impressão tem uma natureza política. A gestão de impressão é conceituada como um processo diádico, que nem sempre é uma ação consciente e deliberada como ocorre na política, que implica a busca pelo alcance de uma meta direcionada. O conceito de política abrange ações com metas direcionadas e o envolvimento de três partes, o que o distingue mais claramente da gestão de impressão.

Para Ferris et al. (2005), a competência política é um construto independente do automonitoramento e da inteligência emocional e relacionado a alguns traços de personalidade e a outros construtos orientados para os aspectos interpessoais, mas não a ponto de indicar uma redundância entre os construtos.

Nesta tese, buscou-se focar o comportamento político que contribui para o atingimento das metas organizacionais e pessoais, uma vez que a ênfase do estudo foi verificar como o comportamento político positivo, especificamente a competência política, contribui para o desenvolvimento na carreira, na atribuição de reputação e legitimidade das lideranças. Para Tanto, nas próximas seções, avaliaremos a perspectiva política na carreira e na liderança e suas perspectivas positivas respectivamente. 


\subsection{Perspectiva política na carreira}

As pesquisas em carreira tradicionalmente foram dominadas por modelos racionais, em que as organizações estabelecem um sistema de carreira e estratégias de promoção focadas no reconhecimento dos profissionais mais produtivos. No entanto a realidade mostra que o mérito não é o único fator responsável pelo sucesso dentro de uma organização. A perspectiva política na carreira tem demonstrado que o sistema de promoção frequentemente tem uma natureza política. Essa perspectiva permite uma descrição mais precisa e realista de como o desenvolvimento na carreira ocorre em várias organizações. A rede de relacionamentos, a política e outras ferramentas sociais parecem ter um papel importante na progressão na carreira (BEDI; SKOWRONSKI, 2014; FERRIS et al., 1989; JUDGE; BRETZ; 1994).

A perspectiva política aplicada à carreira reconhece, primeiramente, a primazia do interesse, que pode ser múltiplo e distinto. As decisões nas organizações resultam da interação desses interesses, por meio da qual os atores mais poderosos acabam alcançando com mais frequência o que eles desejam (MARCH, 1966). A perspectiva política busca explorar como interesse, poder, estrutura oportuna, definição de salários e plano de sucessão contribuem para o desenvolvimento do sistema de carreiras nas organizações. Considerando que o poder é derivado, em parte, do ambiente organizacional e é desenvolvido e exercido através de network, a perspectiva política foca sua atenção em fatores que ocorrem tanto fora como dentro da organização e em características estruturais que possibilitam as interações. A compreensão de conceitos como grupos e network é essencial para a literatura de carreira, por estes enfatizarem as interconexões entre as pessoas, refletindo comportamentos como ajuda no processo de recrutamento e promoção e na redução da competitividade por status e promoção. A perspectiva política do sistema de carreiras das organizações apresenta-se mais descritiva do que prescritiva. Ao enfatizar os elementos políticos que afetam a carreira, é possível desenvolver uma abordagem para analisá-la de acordo com sua realidade e que permita lidar com ela (PFEFFER, 1989).

A análise política na carreira deve considerar os interesses externos, de classe, demográficos e das subunidades formais. A perspectiva de classe argumenta que as classes tentam se reproduzir e continuar a ocupar posições de poder. A literatura dessa perspectiva tem focado o processo de construção de network (DOMHOFF, 1974), aquisição de capital cultural (DIMAGGIO, 1982), bem como habilidades sociais, 
credenciamento e conhecimento cultural (COLLINGS, 1979). A perspectiva política visa compreender por que algumas subunidades têm mais poder do que outras e quais as estratégias do exercício do poder (PFEFFER, 1981).

A fim de entender melhor os critérios utilizados na decisão de promoção, é preciso distinguir as promoções nos diferentes níveis hierárquicos - gerência média ou tática e gerência sênior ou estratégica (LAZEAR; ROSEN, 1979; SHERIDAN et al., 1990). Os autores argumentam que os dois tipos de gerência requerem diferentes habilidades e, por essa razão, diferem também os critérios da decisão da promoção. Os gestores sêniores têm a capacidade de reconhecer e formular estratégias e movimentos táticos na organização, enquanto os gestores de nível médio devem guiar, implementar e defender essas estratégias. Os gestores seniores recebem suportes dos gestores médios que, por sua vez, atuam como intermediários entre os gestores seniores e o resto da equipe. Os gestores médios atuam diariamente na supervisão e coordenação de atividades através de suas várias funções (RAES et al., 2011).

A literatura de carreira aponta várias razões pelas quais pessoas são selecionadas, contratadas ou promovidas nas organizações, como os fatores técnicos, educacionais, de similaridade com o grupo, idade, potencial, entre outros. Nos níveis hierárquicos mais altos, além das questões mencionadas anteriormente, são considerados importantes elementos como: concordância com as metas e filosofia das lideranças, classificação dos cargos e experiência de trabalho anterior com o CEO, o que mostra que tanto a lealdade quanto a incerteza envolvida nesse tipo de carreira tornam a seleção objetiva menos praticável ou desejável nesses casos (PFEFFER, 1989).

A competição, seja pelo interesse de grupos, por recursos escassos, coalisões, exercício do poder e influência, caracteriza melhor o ambiente organizacional e como as coisas acontecem. No intuito de alcançar o sucesso e a efetividade nas organizações, parece ser importante que as pessoas possuam habilidades intuitivas em relação a qual o melhor comportamento para cada situação particular. Um extensivo corpo de trabalhos sobre o tema demonstra que as decisões de emprego, como seleção pessoal, avaliação de performance e promoções, tendem a ter uma natureza política (FERRIS et al., 2000).

Vários autores focaram seus estudos na compreensão das competências gerenciais necessárias para o sucesso de gestores nas organizações no contexto atual. A definição das competências tem como objetivo garantir a evidência das competências requisitadas para o trabalho, possibilitando a definição e sistematização de um perfil 
profissional. A gestão de pessoas na empresa, após a definição do conjunto de competências organizacionais que são desdobradas em níveis de complexidade, procede à especificação das atribuições e responsabilidades para cada nível. A partir daí, as empresas podem promover processos de formação para orientar a aquisição dessas competências e sua avaliação. Esses dados facilitam as tomadas de decisão, uma vez que as competências validadas tornam-se instrumentos de negociação do trabalhador passíveis de gerar mobilidade profissional horizontal ou vertical, interna ou externa à empresa, ganhos de remuneração, acesso à educação continuada, dentre outros aspectos (SANTANNA, 2010).

Com o intuito de identificar quais as habilidades e características necessárias para que gestores sejam promovidos, Claussen et al. (2014) realizaram uma pesquisa na indústria global de videogames, observando as decisões de promoções para gerência média e gerência sênior. Foi utilizada a literatura do capital humano e capital social e da lógica da competição para argumentar que a experiência e a expertise, assim como o tamanho do network do gestor, afetam positivamente a possibilidade de promoção. Na pesquisa, encontrou-se que a experiência e a expertise e o tamanho do network dos pares têm impacto negativo na promoção dos gestores, uma vez que, provavelmente, estes estarão competindo pelo mesmo cargo. Também se verificou que o tamanho do network não apresentou efeito positivo para as promoções dos gestores seniores. Apesar de a teoria da organização assegurar que tanto o nível hierárquico quanto o network possibilitam aos gestores implementarem suas metas estratégicas (RANK, 2008), os autores acreditam que, especialmente os gestores seniores, utilizam a hierarquia formal da empresa para promover suas agendas estratégicas, por isso a importância do network talvez seja menor para esses gestores.

A teoria da competição considera que a promoção é uma competição entre os gestores de nível hierárquico similar (MALCOMSON, 1984). Ao organizar uma competição interna, a organização busca promover aquele que possui a melhor performance, ou seja, aquele gestor que apresenta maior experiência e expertise do que outros (NALEBUFF; STIGLITZ, 1983). No entanto, um estudo realizado pelo Center for Creative Leadership encontrou que a razão mais proeminente de insucesso na carreira dos gestores é a falta de habilidade social e interpessoal (VAN VELSOR; LESLIE, 1995).

Apesar de a experiência e expertise contribuírem para a promoção de gestores, muitas vezes, a habilidade social e a interpessoal também são fatores que afetam o 
sucesso do gestor na nova posição. Dois problemas são comuns no processo de transição para um nível hierárquico superior, frequentemente, os executivos desconhecem que essas passagens requerem mudanças nos seus valores e que é difícil desenvolver os executivos para essa transição (STEPHEN et al., 2001). Os primeiros passos dos profissionais novos na função de liderança constituem-se em ritos de passagem. Esse processo de transição permite que líderes consigam adquirir força emocional, renovem-se para realizar tarefas mais complexas e com maior escopo. A cada passo, o processo de transição fica mais difícil e os desafios aumentam (CHARAN; DROTTER; NOEL, 2010).

\subsection{Perspectiva positiva da política na carreira}

Segundo Pffefer (1992), as pessoas entram na organização e alguma delas se saem melhor do que outras em termos de promoção para posições de níveis mais altos e em termos de poder informal e status. As organizações têm um sistema de carreira que tende a recompensar e encorajar certas atividade e competências mais generosamente do que outras, mesmo que algumas empresas não reconheçam isso. Muitas vezes, o sistema de carreira e as competências valorizadas são, conscientemente, escolhidas como parte da estratégia da empresa.

Aqueles que alcançaram posições de influência na organização e que, portanto, beneficiam-se do sistema de carreira existente, têm um conjunto de habilidades e se engajam em um conjunto de atividades favorecido pelo sistema de carreira. Todavia Pffefer (1992) alerta que, em caso de necessidade de mudança no sistema de carreira diante da imprescindibilidade de um novo conjunto de competências que atendam às novas demandas do mercado, não é provavel que os indivíduos que estejam no topo da organização realizem tais mudanças. Isso porque, para muitos profissionais, a mudança de critérios pode ser interpretada como uma possível ameaça ao seu próprio crescimento. Acredita-se que essas mudanças necessárias poderiam vir de pessoas de fora da organização ou parcialmente de fora da estrutura do poder convencional. Porém, muitas vezes, esses profissionais trazem ideias que estão muito fora da corrente principal da empresa ou não têm acesso à estrutura de poder, e, portanto, não conseguem realizar tais mudanças.

Para Pffefer (1992), a dinâmica de poder é crítica para a adaptação e mudanças nas organizações. A incorporação de novas perspectivas e novas ideias frequentemente 
envolve a redistribuição do poder. O ideal é gerir essa dinâmica para que a mudança seja produzida sem esmagar processos políticos e, assim, destruir a capacidade de adaptação ou mesmo deixar o conflito ficar tão fora de controle que a organização se autodestrua. Uma questão que preocupa as organizações é que as atividades de influência consomem tempo e energia, de modo que um pensamento comum nas empresas poderia ser de que, ao dividir as recompensas uniformemente, diminuiriam as razões para que os profissionais se engajem em atividades políticas para afetar os resultados na carreira, portanto se reduziria o desperdício de recursos.

De maneira geral, distribuir os recursos de forma mais igualitária, por exemplo, salários e promoções, pode ser uma forma eficiente de reduzir as atividades de influência. No entanto é preciso observar que a alocação mais igualitária de recursos para reduzir as lutas por influência, ao mesmo tempo, pode impedir esquemas de alocação contingente; a realocação de ativos entre as divisões operacionais para o uso mais produtivo diminui a atratividade e retenção de talentos na empresa. Isso porque trabalhar com uma base salárial mais igualitária também pode gerar distorções, ou seja, trabalhadores que, em outra situação, ganhariam menos se beneficiarão e aqueles que apresentam uma alta performance e que conseguiriam ofertas melhores no mercado serão prejudicados. $\mathrm{O}$ autor defende que existem maneiras melhores do que criar regras extremas. À medida que as organizações conseguem chegar a um acordo sobre metas e sobre medidas de progresso, as atividades de influência podem ser reduzidas. Todavia, na ausência dessa condição, os custos de influência podem ser uma forma de custo de "transação" - um custo de governança inerente à tomada de decisões sob condições de incerteza e heterogeneidade, ou seja, muitas vezes um custo necessário para realizar as mudanças impostas pelo mercado (PFFEFER, 1992).

Dada à natureza política das organizações, a habilidade de navegar efetivamente na arena política deve resultar em sucesso na carreira, uma vez que o indivíduo possui as ferramentas adequadas para tal. Segundo Liu et al. (2007), o sucesso ou desenvolvimento na carreira no ambiente organizacional depende criticamente das competências individuais, como a competência política, que permite ao profissional uma gestão eficaz e projeção de uma impressão positiva entre os diferentes stakeholder (LIU et al., 2007).

Os atributos da competência política contribuem para o desenvolvimento da reputação profissional. Essa perspectiva reflete a metáfora dos profissionais como empreendedores da sua própria carreira (FERRIS et al., 2000). Compreender melhor os 
conflitos e aspectos intangíveis das organizações pode contribuir para melhorar os processos de retenção de talentos e plano de carreira. Ao manter os talentos na empresa, evita-se a perda de conhecimento e cria-se um sistema mais efetivo no desenvolvimento e na promoção de lideranças.

No contexto organizacional atual, encontra-se um paradoxo frequente relacionado ao incentivo à colaboração por meio do trabalho em grupo e a valorização individualizada da performance do profissional. Nesse cenário de contradição, conquistar o suporte dos outros provavelmente dependerá de muita competência política para administrar esses interesses antagônicos e conflituosos. Uma razão óbvia para a importância da boa relação com os pares é a colaboração, que é considerada essencial para a sobrevivência de uma organização. Outro aspecto positivo é a progressão na carreira; trabalhadores que não se dão bem com seus pares, frequentemente, recebem baixas avaliações sobre sua performance e são preteridos nas promoções. Um profissional que não se relaciona bem com seus pares é normalmente associado a uma pessoa que não sabe trabalhar em grupo e não se comunica bem. Além do fato de que saber se relacionar bem é um requisito importante para posições de supervisão (DUBRIN, 2009).

Um dos maiores erros que as pessoas cometem, segundo Pfeffer (2010b), é pensar que a boa performance e o desempenho no trabalho são suficientes para adquirir poder. Treadway et al. (2013), em uma investigação em dois estudos, relacionaram a performance como uma forma potencial de influência que interage com a competência política na aquisição de poder. A relação performance/poder é vista como inconsistente, isso porque muitos profissionais de alta performance foram incapazes de transformar seus resultados positivos de performance em aumento de poder na organização. A natureza tênue da relação performance/poder sugere a presença de variáveis moderadoras. Esses autores argumentam que a competência política é o melhor mecanismo de obtenção de poder por meio de atitudes que asseguram e influenciam a aquisição de informações e recursos que implicam interações em que a competência política possibilita uma apresentação efetiva da performance, que pode se traduzir na aquisição de poder. Os profissionais com competência política são mais conscientes da sua performance e são habilidosos em apresentar e transmiti-la de uma maneira não ameaçadora e influente. Os achados do estudo mostram que os indivíduos com uma performance positiva tendem a ter maiores níveis de poder interpessoal se eles apresentam competência política. 
Blicke, Oerder e Summer (2010) realizaram um estudo sobre o impacto da competência política na carreira de conselheiros do trabalho eleitos para representar empresas alemãs. A pesquisa mostrou que aqueles profissionais que apresentaram os maiores índices de competência política também foram os que obtiveram mais êxito na carreira. As descobertas do estudo dão suporte à ideia de que por causa das condições de incerteza e ambiguidade, comuns no ambiente organizacional da atualidade, a competência política se torna ainda mais relevante. Ela é um construto que se refere a uma competência individual que pode ser moldada e formada pela interação do indivíduo com o ambiente de trabalho por meio de experiência, mentoring e treinamento No entanto ainda falta treinamento em competências políticas nas organizações (FERRIS et al., 2005; TREADWAY et al., 2005).

Alguns autores sugerem que estudos sobre o sucesso na carreira devem utilizar medidas múltiplas e incluir mediadores multiníveis, como estrutura de network (laços e estrutura), recursos sociais (contatos com pessoas de outras funções e superiores) e benefícios de network (acesso à informação e recursos e apadrinhamento na carreira). Estudos que examinaram a relação entre a competência política e o sucesso na carreira revelaram que os recursos do network, a reputação e o poder pessoal mediaram essa relação e que a habilidade de criar redes de relacionamento (network) apresentou um impacto maior que outras dimensões da competência política. Esses resultados sugerem que os efeitos da competência política no sucesso na carreira podem ser explicados principalmente pela Teoria do Capital Social. No entanto os efeitos da mediação da reputação e do poder também sugerem a importância da gestão da impressão (BLICKLE et al., 2011a, LIU et al., 2010; WEI et al., 2012; KIMURA, 2015).

\subsection{Perspectiva política da liderança}

As teorias tradicionais de liderança foram elaboradas com o pressuposto da racionalidade. Embora vários estudos tenham sido realizados pela Psicologia Social sobre influência e poder nas organizações, existe uma deficiência de estudos que mostrem como o processo político influencia o fenômeno da liderança. Um estudo realizado por House e Aditya (1997) sobre a ciência social na liderança mostra que, apesar de ser uma área de estudos antiga e bastante explorada na literatura, as teorias e pesquisas dão pouca ênfase ao contexto no qual a liderança é desempenhada e ignoram a relação dos líderes com seus superiores, pares e eleitores. Neste estudo, optou-se por 
não explorar as teorias sobre liderança, uma vez que as teorias tradicionais sobre o tema pouco abordam a questão da perspectiva política da liderança, que é o objeto deste estudo.

$\mathrm{O}$ apelo a teorias sobre liderança que sejam mais consistentes e precisas retrata a natureza emaranhada desse fenômeno organizacional. O estudo da liderança é considerado um dos mais complexos e multifacetados dentro dos estudos organizacionais (VAN SETERS; FIELD, 1990). O interesse pelo tema no Brasil tem aumentado bastante nos últimos anos, principalmente a partir de 2006, quando registrou-se um aumento na quantidade de publicações nos encontros acadêmicos dentro do campo das ciências administrativas (DELFINO et al., 2009).

Pela análise das tentativas de conceituação de liderança, alguns pontos comuns puderam ser observados, como: a visão da liderança como um processo social, que envolve a interação entre líder e liderados, e aspectos como influência, relacionamento e resultados (SADLER, 2001; BERGAMINI, 2009). Os estudos atuais da liderança se afastam da visão top-down ou mesmo de uma liderança heroica. As teorias mais recentes de liderança apontam para a importância do relacionamento interpessoal. É esperado dos líderes de hoje que eles saibam compreender os diferentes modelos mentais, saibam dialogar com a equipe, estejam atentos às necessidades e preocupações de seus seguidores, em termos de potencialidade e de desenvolvimento, o que inclui delegar, coaching, crítica construtiva e feedback (AVOLIO; BASS, 1995; SENGE; KAUFER, 2003; KOUZES; POSNER, 1991).

Os líderes atingem seus objetivos influenciando pessoas e fazendo coalizões com outros indivíduos (MINTZBERG, 1983; PFFEFER, 1981). Essa tentativa de influência tipicamente apoia-se na realização de uma variedade de comportamentos, incluindo inúmeras táticas de influência. Várias dessas táticas (persuasão racional, colaboração e consultoria) são consideradas formas legítimas de alcançar um objetivo final e são frequentemente consideradas como parte do processo de decisão formal. No entanto decisões são regularmente tomadas fora do processo formal, e a política engloba métodos informais e técnicas de influência de decisão (PFFEFER, 1981).

A concepção de poder, muitas vezes, é confundida com a de liderança, no entanto são concepções distintas, em que o poder pode ser uma resultante da liderança. A maioria dos estudiosos modernos não concebe a possibilidade de a liderança ser estudada desvinculadamente de influência (NORTHOUSE, 2010). Para Bass (2008), o conceito de influência foi um passo fundamental em direção à melhoria de qualidade e 
quantidade na definição e nos estudos da liderança, sendo esse um dos fatores principais para diferenciar a liderança de gerência. A influência, segundo esse conceito, é um processo multidirecional em razão da interação com diferentes atores. Neste trabalho, considerou-se que a política, por meio da competência política da liderança, é um dos meios efetivos de as lideranças exercerem sua influência e, consequentemente, alcançarem o poder.

Para Yammarino, Dansereau e Kennedy (2001), o estudo da liderança envolve diferentes níveis de análise: diádico, grupal e organizacional. Neste trabalho, o foco da análise será o nível grupal. A análise, no nível grupal, avalia a liderança nos grupos formais e informais. Yulk (1999) levantou algumas questões na busca de uma maior compreensão do papel do líder no nível grupal. Por exemplo, por que alguns membros são mais influentes do que outros dentro do grupo? Quem, dos membros do grupo, será escolhido ou eleito para exercer o papel de líder? O nível grupal foi amplamente investigado por Yulk (1999), em vários trabalhos de campo. Nesse nível de análise, os interesses pessoais são mais evidentes, tornando o processo da influência uma importante ferramenta para a obtenção de resultados organizacionais. Esse autor alega que a teoria da liderança seria mais forte se o processo essencial de influência fosse identificado mais claramente e utilizado para explicar como cada tipo de comportamento afeta cada tipo de variável mediadora e os resultados.

Para Yammarino e Mumford (2012), no nível de análise individual, as diferentes habilidades dos líderes podem ser: conceituais (inteligência, criatividade e sabedoria), experiência de liderança e competência política (astúcia social e influência interpessoal). As habilidades conceituais e experiência de liderança já são bastante conhecidas e consagradas na literatura. As habilidades conceituais contribuem para que o líder identifique problemas, envolva-se na criação de sentido, defina o problema para sua equipe e o direcione para a solução. A experiência de liderança proporciona ao líder a compreensão da responsabilidade e, consequentemente, da sua distribuição e do envolvimento dos outros a alcançarem seus objetivos e metas. A experiência e o tempo de dedicação à equipe fornecem informações valiosas para reconhecer e avaliar informações e para o conhecimento dos membros da equipe. Já a competência política permite ao indivíduo diagnosticar precisamente o contexto social e adaptar o seu comportamento a situações de maneira a selecionar os métodos e táticas mais apropriados para influenciar as pessoas de maneira efetiva (YAMMARINO; MUMFORD, 2012). 
As pesquisas teóricas e empíricas sobre a interseção entre a liderança e a política organizacional são recentes e bastante limitadas. Uma limitação dos estudos de política e liderança refere-se à conotação negativa de política. $\mathrm{O}$ foco na perspectiva negativa da política traz um conhecimento deficiente de todos os efeitos possíveis do comportamento político na organização. Apenas recentemente, com o aumento da atenção dada à literatura da liderança "positiva" é que o comportamento político tem sido descrito de forma positiva, como algo autentico e inventivo (PFFEFER, 1981, 2010). Nesse sentido, a gestão do compartilhamento de significado pela liderança torna a política um processo importante para as realizações individuais e para o cumprimento das metas organizacionais (FERRIS; TREADWAY, 2012).

Ammeter et al. (2002) realizaram o primeiro trabalho de integração dos temas liderança e política nas organizações. Para tanto, elaboraram um modelo sobre a teoria política na liderança. O termo "política aplicada à liderança" refere-se à influência e ao compartilhamento de significado. Esses autores ressaltam que a perspectiva política adotada por eles não necessariamente elenca os líderes como ambiciosos e manipulativos; pelo contrário, a política é vista de maneira neutra, como um fato do cotidiano das organizações. Segundo Ammeter et al. (2002), as teorias tradicionais de liderança foram elaboradas por pressupostos de racionalidade, deixando de lado o processo político. O modelo criado por eles especifica antecedentes, consequência, mediadores e moderadores do processo político na liderança. O modelo leva em consideração a questão do tempo e seu efeito no processo de liderança, uma vez que episódios anteriores refletem na reputação do líder em relação a elementos críticos da liderança como: competência, confiança e efetividade. Essa reputação serve de contexto para episódios futuros de influência da liderança, conforme demonstrado na FIG. 3, a seguir. 
Figura 3 - Modelo processo político da liderança

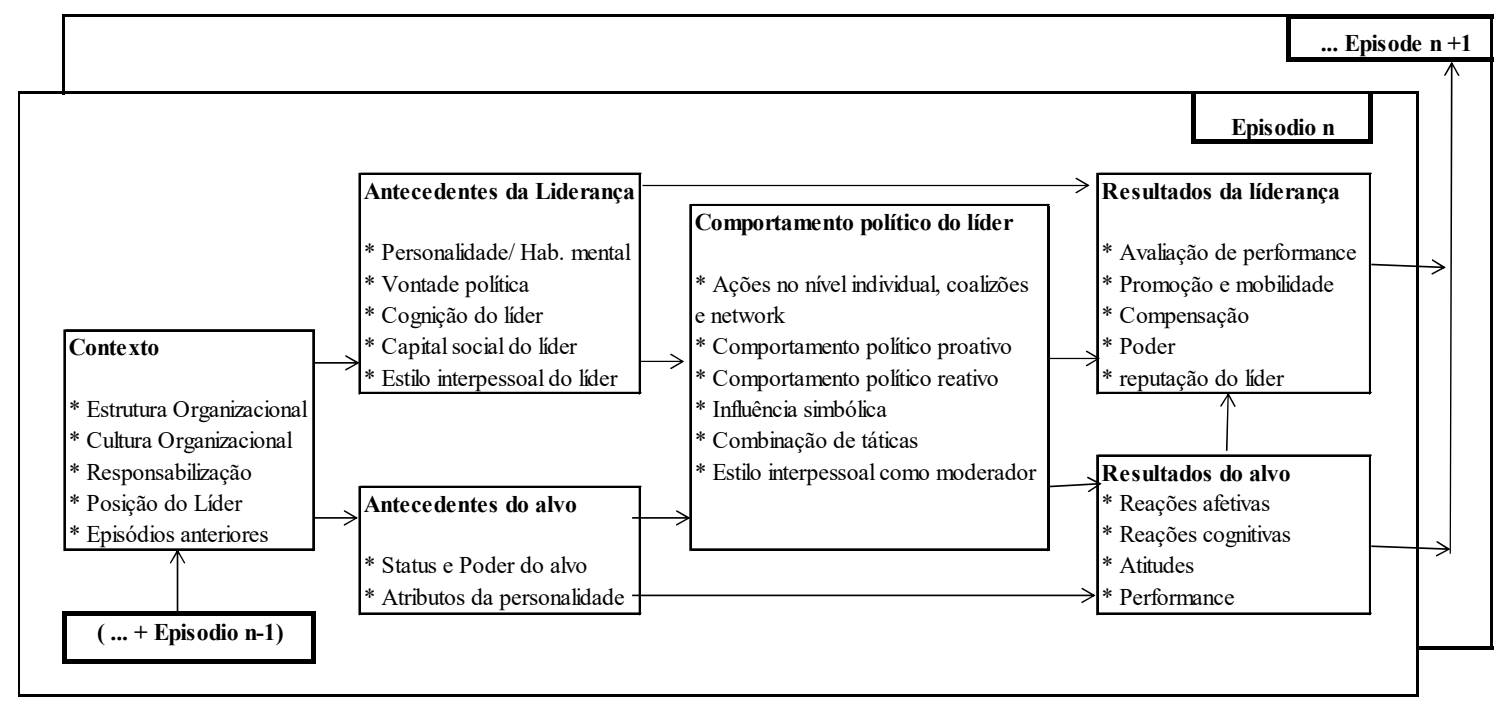

Fonte: Adaptado de AMMER et al. (2002).

Alguns autores acreditam que o foco teórico não deve ser exclusivo nas questões funcionais e tecnológicas dos processos organizacionais, mas que questões como poder, influência, institucionalização, conflitos e disputas por controle devem ser incluídas nas pesquisas organizacionais (PFEFFER; COHEN, 1984). Alguns autores argumentam que a teoria sobre a perspectiva política da liderança se refere de fato à competência política e a outros tipos de competências sociais relacionadas à efetividade social. A competência política é vista de maneira similar a conceitos como inteligência prática, inteligência social, inteligência emocional e a outras noções de estilo interpessoal, como experiência e astúcia (FERRIS et al., 2000; HOUSE; ADITYA, 1997; AMMETER et al., 2002).

\subsection{Perspectiva positiva da política na liderança}

A liderança é um processo de influência social. Os estudos sobre liderança salientam a importância da adaptabilidade social (astúcia social - dimensão da competência política) na efetividade dos gestores (FERRIS et al., 2016). Os líderes são efetivos, na medida em que eles conseguem influenciar seus seguidores no alcance ou na superação da performance, assim como inspirá-los a ir além das suas funções, contribuindo para a efetividade da unidade. Ao trabalhar com e através dos outros, os líderes podem se tornar mais efetivos por meio da criação de redes de relacionamento 
(network), da construção de coalisões e da criação de um capital social. Os líderes bem posicionados e com uma rede de relacionamentos efetiva conseguem armazenar mais recursos para suas unidades e, por sua vez, são valorizados pelos membros de suas equipes. $\mathrm{O}$ acúmulo de amizades, conexões e alianças permite ao líder aumentar o seu capital social para facilitar esforços de mudança para o aumento da efetividade. Todas essas conquistas podem ser facilitadas pela competência política (HOUSE, 1995; LUTHANS; HODGETTS; ROSENKRANTZ, 1988; KOTTER, 1985; AHEARN et al., 2004).

Mintzberg (1983) defende que, para ser bem sucedido no ambiente organizacional, é preciso ter habilidade política. Os líderes com habilidades políticas são capazes de aumentar a probabilidade da percepção positiva dos funcionários de que as ações organizacionais são realizadas para atender ao interesse dos liderados. Os resultados do trabalho desse autor mostram que a competência política do líder é positivamente relacionada à percepção dos subordinados a respeito do suporte organizacional. E que essa percepção é positivamente relacionada à satisfação dos empregados no trabalho. A percepção do suporte organizacional é definida como a crença de que a organização valoriza as contribuições de seus profissionais e que se preocupa com o seu bem-estar (RHOADES; EISENBERGER, 2002). Essa percepção é um importante elemento na definição dos funcionários sobre o contexto do ambiente de trabalho e pode ser vista como um indicador da intenção benevolente ou malevolente da organização em relação às trocas do esforço dos trabalhadores por recompensas e reconhecimento (LYNCH; EISENBERGER; ARMELI, 1999). Algumas pesquisas sugerem que organizações que oferecem suporte aos seus funcionários refletem um ambiente seguro, positivo e cuidadoso (CROPANZANO et al., 1997). Um resultado possível da norma de reciprocidade é que as empresas podem esperar um aumento do esforço e um comportamento "extra" por parte de seus profissionais (GOULDNER, 1960; EISENBERGER et al., 1986). A percepção dos funcionários a respeito do suporte da organização, assim como o desenvolvimento do comprometimento com os outros são formados pelas atribuições que os funcionários fazem em relação aos motivos e à sinceridade das ações, recompensas e políticas da organização.

Algumas estratégias e atitudes efetivas de gestores com competência política foram identificadas: 1) conhecimento de pessoas públicas, capacidade de comportar-se de maneira adequada a cada situação; 2) habilidade de ler e adaptar-se a situações sociais; (3) autocontrole das emoções e expressões transmitindo uma imagem 
apropriada. A competência política é um componente significativo do estilo de liderança e, como um estilo interpessoal, ela combina perceptividade interpessoal e astúcia social com a capacidade de ajustar o comportamento a diferentes situações de uma maneira que é percebida como natural e genuina (FERRIS et al., 2000; HOUSE; ADITYA, 1997; AMMETER et al., 2002).

A competência política da liderança é preditora de várias medidas de efetividade da liderança, como performance no trabalho, automonitoramento, autoeficácia e inteligência emocional. É associada positivamente à performance do grupo, já que os grupos liderados por profissionais com competência política alta desempenham melhor suas funções do que os com baixa competência política (SEMANDAR; ROBINS; FERRIS, 2006; AHEARN et al., 2004).

Líderes com competências políticas funcionam como agentes da organização. É importante lembrar que esses líderes possuem habilidade de agir de maneira a moldar seus motivos de uma forma favorável. As ações desses líderes tendem a ser vistas como mais sinceras e genuínas. A percepção do suporte da organização tem um papel na percepção de justiça atribuída às ações da organização. O padrão de justiça na distribuição de recursos sinaliza que a organização se preocupa com o bem-estar dos trabalhadores (TREADWAY et al., 2004; SHORE; SHORE, 1995).

Os líderes politicamente competentes são capazes de construir uma larga base social e um capital organizacional e acabam por expandir os recursos disponíveis aos seus liderados, aumentar o peso de suas recomendações em relação às indicações para promoções e proporcionar uma maior reputação organizacional ao seu grupo de liderados. Na medida em que os líderes aumentam seu poder de influência nas decisões de promoção, os liderados percebem um aumento do suporte organizacional, já que essa percepção é influenciada pelo acesso a promoções (RHOADES; EISENBERGER, 2002; FERRIS et al., 2003). O comportamento flexível e adaptável dos líderes permite que eles consigam captar as necessidades e aspirações dos liderados, afetando o clima no trabalho o que acaba gerando uma reação e um comportamento positivo dos liderados em relação a sua satisfação no trabalho, ao comportamento cidadão e à redução da intenção de deixar a organização. Esse comportamento influencia a confiança no líder, a percepção da sua competência e credibilidade. Um estudo realizado por Ahearn et al. (2004) mostrou que a competência política contribui para a facilitação da interação entre os membros do grupo. Talvez a vantagem mais intuitiva da competência política no ambiente de trabalho seja a crescente performance 
organizacional e os índices de resultados (AMMETER et al., 2002; FERRIS et al., 2000).

Em um artigo sobre o aspecto positivo do comportamento político nas organizações, Hochwarter (2012) defende que a prática do comportamento político pode levar à redução da ambiguidade e da incerteza. A habilidade de assegurar informações essenciais pode ser um importante mecanismo de adaptação, já que reduz as incongruências de informações. A restauração da justiça é outro aspecto positivo da competência política. Alguns benefícios intrínsecos da competência política, como network e comprometimento organizacional contribuem para a satisfação, produtividade e intenção de permanecer na organização. As lideranças politicamente habilidosas conseguem desenvolver e estruturar significados compartilhados, ajudando a rápida reorientação da empresa em casos de mudanças ou novas informações. No entanto a principal vantagem da competência política da liderança é proporcionar recursos e suporte aos seus liderados.

Em muitos casos, os liderados acabam criando um sentimento de retribuição à organização que foi reconhecido como um mediador da relação entre a percepção da justiça organizacional e os resultados da organização, como comprometimento afetivo, espontaneidade, desempenho e intenção de saída (EISENBERGER et al., 2001).

A maioria das pesquisas e teorias sobre política organizacional enfocam predominantemente os aspectos negativos e disfuncionais do comportamento político. No entanto os líderes podem se comportar politicamente com esforços para beneficiar a organização e seus liderados. O comportamento político pode gerar suporte na mobilização das coalizões, na melhoria da posição pessoal, na gestão do compartilhamento de significado, bem como melhoria na tomada de decisão, no ato de fazer coisas acontecerem, no suporte político aos liderados, entre outros itens (CRAPANZANO et al., 1997). O suporte político da liderança, por exemplo, é um construto que tem sido explorado nos estudos de Parker (2014). O construto seguiu os fundamentos da perspectiva positiva da política nas organizações, ou seja, o suporte político da liderança é visto como uma forma de a liderança usar sua competência política para beneficiar seus liderados. Alguns exemplos de resultados positivos potenciais para os liderados são: 1) aquisição de recursos; 2) criação de oportunidades de desenvolvimento; 3) restauração da justiça e 4) remoção de obstáculos. O suporte político aos liderados pode criar um sentimento de reciprocidade nos liderados, que tenderão a apoiar sua liderança, podendo contribuir para o sucesso da organização, para 
a legitimação e a carreira da liderança. No entanto esse autor alerta para o fato de que a forma como o comportamento se dá pode gerar uma percepção negativa, caso sua conquista se dê por meio da violação da norma, falta de equidade e/ou intenção do benefício próprio.

O termo competência política foi introduzido como uma competência necessária para ser efetivo no ambiente ambíguo e turbulento das organizações (PFEFFER, 1981). Na última década, vários estudos foram realizados para investigar os efeitos da competência política. Esses estudos têm mostrado que a competência política está relacionada a importantes resultados organizacionais, como sucesso na carreira e satisfação no trabalho. Ao mesmo tempo, outros estudos mostraram inconsistências na relação entre competência política e performance no trabalho. A fim de esclarecer essa questão, Bedi e Skowronski (2014) realizaram uma investigação por meio de metaanálise de estudos sobre competência política, envolvendo uma larga quantidade de variáveis associadas à competência política, que pudessem sintetizar a literatura acerca dos seus antecedentes, correlatos e consequências. A conclusão do estudo mostrou que a competência política oferece vantagens claras associadas a uma melhor performance, ao sucesso na carreira e à satisfação no trabalho. $\mathrm{O}$ estudo sugere ainda que a competência política é particularmente importante para as posições de liderança, uma vez que a performance dos grupos apresentou melhores resultados quando coordenados por um líder astuto.

Um estudo realizado por Buchanan (2008) com 250 executivos ingleses mostrou que a maioria dos gestores percebe o comportamento político como ético e necessário e aspectos como efetividade organizacional, mudança, mobilização de recursos e reputação foram atribuídos às táticas políticas. Foi constatado ainda que, apesar da importância dada aos aspectos políticos, $80 \%$ desses executivos não tiveram treinamento na área. Pode-se perceber, portanto, que, apesar da importância, o tema é pouco explorado nas organizações, faltando discussões, práticas e treinamento sobre a temática.

A percepção do comportamento político está diretamente relacionada ao julgamento da intenção dos seus atores. Uma das dimensões críticas da competência política chamada sinceridade evidente trata da questão de o profissional ser exatamente o que ele aparenta ser. Um estudo recente indicou que a relação entre a competência política do líder e a confiança dos subordinados no líder é mediada pelo comportamento íntegro (FRIEDER; BASIK, 2016). 
O comportamento político pode resultar em sucesso na carreira, preenchimento das necessidades de poder, alcance de status, alcance de boa performance de líderes, facilitação da performance e de oportunidades de crescimento dos liderados, conseguir que o trabalho seja feito de forma eficiente e efetiva pelos outros, reputação, alcance de metas, sobrevivência da organização. A percepção positiva sobre a política organizacional pode levar a maior satisfação com o trabalho, superiores e com o ambiente organizacional (ULLAH; JAFRI; DOST, 2011).

Para Krackhardt (1990), indivíduos com grande conhecimento e astúcia sobre o contexto social e relacional tendem a ser os mais poderosos, e os indivíduos poderosos geralmente possuem grandes habilidades de comunicação e relacional para construir relacionamentos. Apesar de não se abordarem aqui as teorias de liderança diretamente, acredita-se que, para o propósito deste estudo, faz-se necessária a distinção entre a conceituação de gestores e líderes. Portanto, na próxima seção, discutir-se-ão essas diferenças.

\subsection{Gestores e líderes}

As mudanças nas organizações e aquelas projetadas para o futuro sugerem que as interações sociais serão ainda mais características dos ambientes de trabalho contemporâneos e futuros. As organizações têm alterado seus processos, deixando menos rígidas as fronteiras e as descrições das funções no trabalho. Os papéis na organização estão em constantes mudanças, com maior fluidez nas responsabilidades e atribuições por projeto. Muitas empresas eliminaram níveis de gerência e implementaram estruturas de trabalho baseadas em equipes. A estruturação da empresa em trabalhos em grupo torna mandatória a seleção e o desenvolvimento de uma força de trabalho que seja mais astuta socialmente. Mecanismos alternativos de controle e coordenação têm substituído à estrutura burocrática tradicional, o que reflete a mudança no papel dos gestores. Para Hooijberg, Hunt e Dodge (1997), o termo "líder gerencial" seria o mais adequado para esse novo contexto. Para esses autores, o líder gerencial deve navegar em situações que não apresentam os níveis tradicionais de autoridade e controle. O importante é que a atitude do líder gerencial seja apropriada, usando uma gama de comportamentos da liderança. Hooijberg (1996) considera que gestores que utilizam uma vasta gama de comportamentos de liderança são vistos como mais efetivos do que aqueles mais limitados. 
A questão da eficácia é considerada a raiz para a distinção entre os conceitos de gerência e liderança. Muitos autores se preocuparam em diferenciar gestores de líderes. Para Mintzberg (1979), a influência dos gestores é mais clara no papel da liderança. O que diferencia um gestor de um bom líder é que a autoridade formal confere ao gerente um grande poder potencial, mas é a liderança que determinará o quanto de poder ele vai conseguir obter. Para Bennis e Nannus (1985), os gerentes são pessoas que fazem certo as coisas e os líderes são pessoas que fazem as coisas certas. Para Malvezzi (2015), gerentes não são líderes, mas autoridades de quem se espera a construção de suas lideranças.

Para Zaleznik (1997), gerentes e líderes compreendem dois tipos distintos de perfis, muito embora se possam encontrá-los presentes em um mesmo indivíduo. $\mathrm{O}$ autor publicou um artigo cujo título interroga se gestores e líderes são diferentes. Esse autor desenvolve sua argumentação e conclui que a diferença entre gestores e líderes está associada a uma série de fatores: os objetivos que se esperam de um gerente derivam de necessidades e não de vontades, enquanto os gestores se sobressaem ao apaziguar conflitos e, ao mesmo tempo, assegurar que atividades do dia a dia sejam cumpridas. Os líderes adotam atitudes pessoais e proativas em relação aos objetivos, buscam oportunidades e recompensas, inspiram subordinados e estimulam o processo criativo com a própria energia. Seus relacionamentos com os subordinados e colegas são intensos, e o ambiente de trabalho é habitualmente caótico. A distinção está, portanto, mais entre o grau de atenção dada pelos gerentes à forma "como as coisas são feitas" e a atenção dos líderes sobre "o que" os eventos e decisões significam para os participantes (ZALEZNIK, 1977).

Nessa perspectiva, é frequente líderes serem definidos com adjetivos de intenso teor emocional, atraindo fortes sentimentos de identidade, indiferença ou de amor e ódio. No entanto, para sobreviverem e serem bem sucedidas, as empresas necessitam de ambos os perfis, assim como de superarem os desafios na construção de contextos capacitantes que permitam o desenvolvimento de seus profissionais (ZALEZNIK, 1977). Pode-se perceber que, de modo geral, a gestão é caracterizada por duas grandes funções: a de planejamento e execução de tarefas, que é atrelada à função do gestor, e outra que se dá mais nas estruturas subjetivas dos indivíduos, nos significados e identidades, que é associada à liderança. Esse posicionamento mais comum tende a valorizar a figura do líder. No entanto existem ainda autores como Gadner (1993) que defendem que não há distinção entre eles. 
Segundo Dutra (obra em fase de pré-publicação, 2017), ao longo de suas pesquisas sobre liderança foi possível observar que as distinções entre líderes e gestores se mostraram pouco instrumentais. Percebeu-se a necessidade de distinguir o líder que conduz sua equipe em uma realidade muito estruturada e que não está inserido na discussão da distribuição de recursos, do líder que lida com a incerteza e ambiguidade e está inserido na gestão de recursos escassos. Esse autor passou a adotar outra forma de fazer tal distinção. Para ele, o gestor difere do líder por estar na arena política da organização. Nem todo líder está na arena política e nem todo o gestor tem equipes para liderar. É comum nas organizações gestores que estão na arena política não terem subordinados e, por essa razão, necessitam liderar por influência. A realidade das organizações mostra que, se por um lado, existem bons líderes de equipes que são um fracasso politicamente e acabam comprometendo a influência política de seus subordinados, por outro lado, é possível encontrar bons gestores que são péssimos líderes. Isso ocorre em razão de alguns profissionais conseguirem se articular bem na arena política, mas agirem de modo inadequado com suas equipes. Existem ainda gestores que ostentam o título, mas agem e pensam como técnicos.

A visão de Dutra (obra em fase de pré-publicação, 2017) sobre a distinção entre líder e gestor difere do pensamento comum, porque seu posicionamento leva em consideração a "arena política" das organizações. Para ele, o gestor sempre será um líder independentemente de ter uma equipe subordinada a ele. O gestor sempre exercerá a liderança na relação com seus pares, superiores e outras pessoas que possam estar ligadas a ele em uma relação hierárquica ou não, mas sobre quem, para realização do seu trabalho, ele necessite exercer influência. No entanto o autor considera que, nos casos onde haja uma relação hierárquica, o gestor é responsável por representar os interesses e as necessidades de sua equipe na arena política. Já nos casos em que não exista essa relação hierárquica, o gestor deverá liderar por influência, estimulando as pessoas a realizarem seus trabalhos. Nesse sentido, o grande desafio das organizações na escolha de seus gestores é de buscar aqueles vocacionados para atuar na arena política e, ao mesmo tempo, capazes de serem bons líderes.

Nesta pesquisa, trabalha-se com a ideia de que um mesmo profissional possa exercer o papel de gestor e de líder e defende-se ainda que a competência política pode contribuir para que gestores consigam atuar bem na "arena política" das organizações e, ao mesmo tempo, possam ser bons líderes para suas equipes. Nas seções seguintes, será discutido o papel dos gestores e líderes nas organizações. 


\subsubsection{Papel dos gestores na organização}

Uma visão mais crítica do papel dos gestores nas organizações foi apresentada por Mintzberg (1975). Para esse autor, as primeiras definições das funções dos gestores (planejar, organizar, comandar, coordenar e controlar) foram disseminadas pelo estudo clássico de Henry Fayol. Essas funções descrevem muito pouco do que realmente os gerentes fazem. Elas indicam apenas alguns objetivos vagos sobre o trabalho do gestor. Com o intuito de descobrir a natureza do trabalho dos gestores, ele empreendeu pesquisas sistemáticas envolvendo observação e análise de diários detalhados das tarefas dos gestores e concluiu que essas funções normativas são descrições mais folclóricas sobre as atividades dos gestores. Os fatos mostram que os gestores não são tão reflexivos nem trabalham de maneira regular e que também não utilizam os sistemas de informação formal da empresa como fonte de obtenção de dados. Na realidade, os gestores acabam lidando com papéis complexos e intermitentes relacionados às atividades interpessoal, informacional e de tomada de decisão, em episódios curtos e desordenados, com pessoas de dentro e de fora da organização.

Mintzberg (1975) descreveu como os gestores gastam seu tempo e quais atividades eles realizam no seu dia a dia de trabalho. $\mathrm{O}$ estudo envolveu todos os tipos de gestores. Ele caracteriza o trabalho dos gestores como atividades curtas, que duram poucos minutos, com interrupções constantes e práticas intensas de contatos verbais, que podem tomar de $66 \%$ a $80 \%$ do tempo dos gestores para obtenção de informações importantes externas e internas à organização. $\mathrm{O}$ acesso à informação pode ocorrer por cinco meios principais: documentos, ligações telefônicas, reuniões agendadas, reuniões não agendadas e observação. A obtenção de informação é um aspecto tão importante para os gestores que muitos deles deixam as portas de suas salas abertas e posicionam suas mesas de modo a avistar o máximo possível da empresa e a passagem de pessoas. Tudo isso com o objetivo de encorajar a entrada de pessoas para manutenção do fluxo de informação. Os gestores arcam com o custo da interrupção do seu trabalho, independentemente do que estejam fazendo, em prol da oportunidade de obter informações. O gerente é atormentado pelas possibilidades do que ele poderia fazer e o que ele deve fazer. Outra função dele é o trabalho de planejamento, que precisa ser feito e acaba sendo realizado pelos gestores implicitamente no contexto diário de suas ações e não de maneira reservada durante semanas, como seria de se esperar. Os gestores respondem aos estímulos em tempo real, são indivíduos condicionados por seu trabalho 
a preferirem viver a ação a retardá-la. Mintzberg (1975) encontrou um papel intrínseco à tarefa do gestor relacionada à função cerimonial, como participação em festas e eventos da empresa, participação em jantares com superiores, reunião com clientes importantes entre outros acontecimentos.

O gestor é a pessoa responsável pela organização como um todo ou por alguma de suas subunidades. Exceto pelo CEO, essa definição pode incluir desde o vicepresidente ao chefe de departamento. Essas pessoas têm em comum o fato de possuirem uma autoridade formal, da qual vem o status que leva a várias relações interpessoais e, dessas relações, vem o acesso à informação. A informação, por sua vez, permite ao gestor tomar decisões e montar estratégias para sua unidade. O tamanho da organização pode influenciar um pouco as atividades dos gestores, uma vez que, como uma empresa menor não consegue bancar profissionais especialistas, os gestores acabam realizando atividades rotineiras ou sendo obrigados a substituir profissionais da operação em sua falta, em razão do quadro reduzido de profissionais. No entanto, de maneira geral, o trabalho do gestor pode ser descrito em termos de vários papéis ou conjunto de comportamentos identificados com a posição.

A autoridade formal dá origem a três papéis interpessoais que levam a três papéis informacionais, e esses dois conjuntos de papéis levam a quatro papéis ligados à tomada de decisão. Mintzberg (1975) classifica as funções dos gestores em termos de tipologia de papéis, sendo que os três papéis interpessoais são: 1) pessoa representativa, que corresponde ao papel de participar da função cerimonial e comunicar decisões não muito importantes, mas que suavizam o funcionamento da organização; 2) liderança, que é o papel de cuidar das pessoas da sua unidade, de contratá-las, treiná-las, motiválas e reconciliar suas necessidades individuais com as da organização; 3) papel de conexão, que está ligado à comunicação do gestor com pessoas como pares, profissionais de outras unidades, fornecedores que estão fora da linha vertical. Já os três papéis informacionais são: 1) monitor, que é o papel de centro nervoso da sua unidade ou organização. O gestor pode não saber tudo, mas ele tipicamente sabe mais do que qualquer outro membro da sua equipe por usar o poder da sua posição para criar relacionamentos que lhe ofereçam uma base de informações; 2) disseminador, cujo papel é de compartilhar e distribuir a informação para seus subordinados que, caso contrário, não teriam acesso a tal informação; 3) porta-voz, que tem o papel de levar informações para fora da sua unidade, fazer discurso em favor de uma causa da organização e informar pessoas influentes na organização sobre questões financeiras, 
principais clientes e sobre o fluxo de trabalho. Os quatro papéis ligados à tomada de decisão, que utilizam a entrada de informação para essa tomada de decisão são: 1) empreendedor, que deve adaptar a sua unidade às condições de mudança do ambiente; 2) administrador de conflito, que retrata o papel do gestor de responder às pressões do ambiente, criar uma unidade que seja maior que a soma das suas partes, conduzir o trabalho da equipe; 3) alocador de recurso, cuja tarefa é de decidir como distribuir os recursos disponíveis da organização, incluindo o seu próprio tempo e como o trabalho e as tarefas devem ser divididas; 4) negociador, que é um papel fundamental, que envolve a consignação de recursos no tempo real de maneira a utilizar as informações que ele tem para alcançar os melhores acordos.

Os gestores nos cargos mais altos lidam com escolhas complexas e têm que considerar o impacto de cada decisão em outras decisões e se preocupar com a estratégia da empresa. Eles precisam se assegurar de que a decisão será aceita por aqueles que influenciam a organização e assegurar que os recursos serão suficientes e não se excederam. É preciso ainda entender os custos, os benefícios e as características de cada proposta. Uma solução comum que os gestores encontram para a aprovação de propostas é escolher a pessoa ao invés da proposta, assim ele autoriza os projetos apresentados a ele por pessoas em cujo julgamento ele confia. Mas nem sempre é possível escapar de uma decisão usando esse critério de escolha.

A pressão no trabalho pode levar o gerente a ser superficial em suas ações, a sobrecarregar-se de atividades, encorajar interrupções, responder rapidamente a estímulos, buscar o tangível e evitar o abstrato, tomar decisões agregando pouco e fazer tudo abruptamente. Apesar de os gestores efetivos terem que adaptar suas ações respondendo rapidamente a um número variado de problemas, o perigo no trabalho do gestor é que ele responda a tudo de maneira igual (abruptamente) e que não transforme os pedaços de informação em uma figura ou modelo compreensível do seu trabalho e do mundo. Em momentos de questões complexas, os gerentes sêniores ganham por terem relacionamento com outros gestores da própria organização que possam ter alguma informação que lhes falta tempo para sondar nesses momentos mais complexos. Os gestores conseguem ser mais efetivos quando aprendem a compartilhar as informações com seus analistas e estes conseguem se adaptar às necessidades dos seus gestores ajudando-os a organizar seu tempo, monitorar projetos, elaborar planos de contingência e desenvolver modelos que contribuam para a definição de escolhas e tomada de decisão. Para tanto, um desafio importante dos gestores é encontrar formas sistemáticas 
de compartilhar informações privilegiadas aos seus colaboradores, a fim de garantir que eles possam tomar decisões efetivas.

A efetividade de um gestor está diretamente relacionada à compreensão do seu próprio trabalho, e sua performance depende de quão bem ele entende e responde às pressões e dilemas da sua função. Gestores efetivos transformam suas obrigações em vantagens para si mesmos: o discurso se transforma em uma oportunidade para defender uma causa, uma reunião passa a ser um momento para reorganizar um departamento fraco, a visita a um cliente importante é a chance de extrair informações sobre o mercado. É preciso que o gestor saiba liberar tempo para atividades que julgue importantes, tornando-as como suas obrigações. Tempo livre é feito e não encontrado.

Vários autores focaram seus estudos na compreensão das competências gerenciais necessárias para o sucesso de gestores nas organizações no contexto atual. Rhinesmith (1993) destacou como competências gerenciais fundamentais: capacidade de gerir a competitividade (capacidade de coletar informações relativas a pessoal, capital, tecnologia, fornecedores, processos ou oportunidades de mercado em uma base global e saber utilizá-las); capacidade de gerir a complexidade (capacidade de apreender o todo, ter visão sistêmica e estar apto a lidar com interesses concorrentes, contradições e conflitos inerentes a esta época, gerir interesses de múltiplos parceiros e gerenciar várias questões ao mesmo tempo); capacidade de gerir a adaptabilidade (ter flexibilidade, adaptabilidade e disposição para a mudança, ter equilíbrio emocional, tolerância ao estresse, energia e maturidade); capacidade de gerir a incerteza (capacidade de lidar com transformações contínuas por meio do equilíbrio entre mudança e controle); capacidade de gerir o aprendizado (capacidade de aprender sobre si mesmo continuamente, treinar e desenvolver os demais e facilitar a constante aprendizagem organizacional).

Coda (1999), a partir de estudo realizado em empresas brasileiras do setor elétrico, destacou um elenco de competências gerenciais requeridas: visão estratégica do negócio; capacidade de identificar e definir, com clareza e exatidão, objetivos e metas para a equipe e indivíduos, programando as atividades, definindo indicadores de resultados e gerenciando-os com vistas ao alcance dos objetivos esperados; orientação para a qualidade; capacidade de utilizar os ativos intelectuais das pessoas com quem trabalha, identificando potencialidades e canalizando-as para o trabalho criativo e desafiador; capacidade de gerir conflitos; capacidade de dar feedback; capacidade de utilizar recursos. 
Pelas descrições acima, pode-se verificar que as competências gerenciais estão fortemente relacionadas à capacidade de relacionamento interpessoal e mobilização dos gestores. Para Zaccaro (2002), a inteligência social é uma competência-chave para as lideranças. A capacidade de escolher de maneira efetiva o comportamento mais adequado entre os vários possíveis é vista como uma habilidade fundamental para a emergência de uma liderança. A influência social bem sucedida de um líder requer o domínio de uma gama de habilidades e a capacidade de selecioná-las e aplicá-las nas situações apropriadas. A seguir, será discutido o papel das lideranças nas organizações.

\subsubsection{Papel das lideranças na organização}

Num mercado competitivo e globalizado, os líderes desempenham um papel estratégico, sendo responsáveis por resultados assertivos. Líderes preparados oferecem vantagem competitiva sustentável, sendo responsáveis pela efetivação das estratégias organizacionais, argumento das teorias que se baseiam em recursos (Resource Based View) e em estudos referentes à gestão estratégica de pessoas (WRIGHT et al., 2001; HUSELID, 1995; BOXALL, 1996; LEPAK; SNELL, 1999).

As teorias clássicas organizacionais foram construídas segundo o conceito da burocracia, com estruturas de comando e informação tradicionalmente de cima para baixo e divisão de tarefas. As mudanças recentes na estrutura de trabalho aumentaram as interações desestruturadas entre membros de uma equipe, de pares, superiores, subordinados e clientes. Esse contexto de mudanças sugere que o papel dos líderes também está mudando. Os líderes, que antes eram descritos como guardiões, agora são vistos mais como coach e facilitadores. O líder bem sucedido, nesse cenário, é responsável por eliminar barreiras, incluindo a remoção de impedimentos estruturais. Isso requer que os gestores possuam um conjunto de competências diferentes daquelas previamente necessárias (CASCIO, 1995; AHEARN et al., 2004).

Nesse contexto, torna-se cada vez mais comum a discussão sobre o líder global. No sentido literal, global refere-se ao que é mundial e universal. E, na administração, esse sentido vem sendo ampliado, incorporando a transição de uma economia baseada na indústria para aquela baseada na informação, a chamada economia global do conhecimento (CRAWFORD, 1994). Nesse mercado, uma empresa precisa ter atributos aparentemente contraditórios, paradoxais. A gestão organizacional envolve paradoxos que não constituem uma questão de escolha, mas de dualidades que precisam 
ser reconciliadas e equilibradas dinamicamente Os líderes atuais terão que saber lidar e conviver com essas dualidades (TANURE; EVANS; PUICK, 2007).

Bons líderes diferenciam seu posicionamento nas equipes e na organização. $\mathrm{O}$ posicionamento é uma dimensão da política nas organizações e que é considerado um fenômeno no nível individual. O posicionamento descreve a relativa colocação do líder entre outros indivíduos, seja nas relações diádicas, com sua equipe ou com outras equipes. Além do posicionamento no organograma, na rede de gestores ou nas redes externas à organização (entre organizações), o posicionamento direciona a localização física, psicológica, econômica e o "espaço político" para a realização de acordos e negociações. O posicionamento central do líder nas redes de relacionamento da organização tem impacto em vários resultados organizacionais. O líder deve buscar desenvolver suas redes de relacionamento e criar alianças dentro e fora da organização. Com respeito a seu posicionamento nas redes de relação externas à organização, o líder pode conseguir alterar as relações, expandindo as fronteiras das atividades da empresa ou representando a empresa diante de outras organizações (YAMMARINO; MUMFORD, 2012).

Segundo alguns autores, para que a teoria sobre a liderança continue a evoluir e possa proporcionar aplicação prática para os gestores, os pesquisadores devem reconhecer que liderança: 1) é um processo complexo, interativo, com elementos comportamentais, relacionais e situacionais; 2) encontra-se não apenas no líder, mas ocorre nos níveis individuais, diádicos, grupais e organizacionais; 3) promove-se dos altos níveis organizacionais para os mais baixos e vice-versa; 4) ocorre tanto internamente, nas interações entre líderes e subordinados, como externamente, no ambiente situacional; 5) motiva intrinsecamente pessoas, melhorando suas expectativas, e não apenas extrinsecamente, por meio de sistemas de recompensa (VAN SETERS; FIELD, 1990).

Para Pffefer (1992), nas corporações, o problema é como fazer as coisas acontecerem, como resolver os vários problemas que as organizações de diferentes tamanhos e tipos enfrentam. Desenvolver e exercitar poder requerem vontade e competência. O primeiro papel que uma liderança precisa desempenhar para conseguir gerenciar o poder é reconhecer que, em quase toda organização, há uma variedade de interesses. Para tanto, é preciso diagnosticar o panorama político e descobrir quais interesses são relevantes e quais subdivisões são importantes politicamente. Identificar os clusters de interesses dentro da organização, ou seja, onde eles estão e a quem eles 
pertencem. Descobrir os pontos de vista dos vários indivíduos ou subunidades sobre as questões que interessam a eles. Não é difícil a convivência entre aqueles que se parecem em caráter e opinião. Todavia o segredo do sucesso é a habilidade de conseguir que as pessoas, mesmo aquelas que diferem do líder ou com as quais ele não tenha afinidade, façam o que precisa ser feito. Para ter sucesso é preciso compreender as relações de poder e as maneiras que levam a sua aquisição e entender como as estratégias e táticas de poder são desenvolvidas e utilizadas nas organizações, o que inclui a importância do tempo, a utilização da estrutura, a Psicologia Social do comprometimento e outras formas de influência interpessoal. Nas próximas seções, serão discutidos os possíveis resultados da competência política: reputação, atribuição de legitimidade e desenvolvimento na carreira.

\subsection{Possíveis resultados da competência política}

Teóricos argumentam que a competência política é um importante prognóstico da efetividade da liderança, dos resultados dos liderados e da performance da equipe. Estudos empíricos dão suporte ao argumento de que a competência política da liderança impacta a performance, por meio de uma seleção efetiva, e a execução de um comportamento apropriado à situação (FERRIS et al., 2005; FERRIS et al., 2007; AHEARN et al., 2004). As habilidades interpessoais, como a competência política, afetam não apenas o tipo de comportamento político utilizado pelo líder, mas também afetam diretamente os seus resultados no nível individual. Os líderes politicamente competentes devem ter consciência do aumento do seu poder organizacional, da intensificação da sua reputação interpessoal e da melhora nas recompensas organizacionais (AMMETER et al., 2002). Neste estudo, trabalhou-se com a proposição de que a competência política da liderança contribui para o aumento da reputação, para a atribuição de legitimidade da liderança e para o desenvolvimento na carreira. Por essa razão, nas próximas seções serão abordaremos estes construtos.

\subsubsection{Reputação}

A vida nas organizações opera de maneira que sua realidade é baseada nas percepções, interpretações, imagens e impressões. A política nas organizações pode ser 
caracterizada como a gestão de significado compartilhado, de tal modo que as pessoas apresentam seu comportamento de maneira a adequar suas ações ao que é aceito e endossado nas organizações. Alguns autores argumentam que a reputação é um construto mais sociopolítico do que científico e que ainda é pouco compreendido tanto no nível individual, quanto no de grupo e no organizacional. Apesar de as dimensões da reputação serem pouco exploradas, Ferris et al. (2003) e Ferris et al. (2016) sugerem que pelo menos duas dimensões básicas e de ordem superior da reputação individual ou organizacional são: performance/resultados e caráter/ integridade.

A reputação é baseada em um conjunto de fatores que incluem o comportamento passado dos indivíduos, suas ações, assim como seu capital humano, suas habilidades sociais e sua competência política (ZINKO et al., 2012). Em um estudo empírico sobre reputação, Blicke et al. (2011) encontraram suporte na afirmação de que a reputação é mediadora dos efeitos da competência política nas mensurações de sucesso na carreira (posição na estrutura, salário e satisfação na carreira). Os achados desse estudo salientam a contribuição da competência política na formação da reputação e o seu papel para a formação de uma imagem favorável.

A reputação é uma forma de identidade feita de uma combinação complexa de características e realizações percebidas, de um comportamento demonstrado e de imagens pretendidas durante um período de tempo. A reputação existe de forma separada na mente de cada observador, seja através da observação direta ou por meio de relatos de fontes secundárias. Essa reputação tem dois aspectos amplos: a performance ou fazer com que as coisas aconteçam e caráter e integridade percebidos. O conceito de identidade implica diferenças potenciais até conflitantes sobre a reputação de acordo com as pessoas ou grupo-alvo (FERRIS et al., 2005).

A reputação é um construto baseado na percepção, tendo, portanto, uma natureza subjetiva e sendo definida pelo olhar do espectador. Essa definição sugere que a reputação é influenciada pelas características pessoais (incluindo variáveis não controladas como gênero, raça, etnia, idade) que podem servir como um sinal ou uma representação da reputação. Ao mesmo tempo, outra parte importante da definição de reputação está relacionada com uma determinada conquista ou característica desenvolvida, tal como a competência política.

Em uma revisão sobre a reputação e sobre os multiníveis de análise do construto, Ferris et al. (2014) sugeriram que a análise da reputação é praticamente a mesma em todos os níveis. O estudo mostrou que os antecedentes e as consequências da 
reputação são essencialmente as mesmas nos três níveis (individual, unidade e organizacional). Os preditores comuns entre os níveis são: competência política, habilidade mental geral, reputação do departamento e performance financeira da empresa, além de características sedimentadas por um período de tempo prolongado, incluindo fatores como o contexto da entidade e as percepções dos stakeholders. A reputação pode ser considerada um ativo que pode dar acesso a recursos adicionais valiosos.

A reputação individual é um fato tanto da vida social como da organizacional. Os indivíduos podem desenvolver sua reputação no trabalho principalmente em razão da sua capacidade de ter uma boa performance, por serem colaborativos e ajudar os outros. A forma como os stakeholders interpretam o comportamento dos gestores, como funcional ou disfuncional, é moderado pelos motivos e intenções que eles atribuem ao comportamento do líder. A percepção sobre a performance e efetividade de um líder serve para redefinir ou reforçar a reputação dele e também para modificar ou reforçar o seu estilo. A reputação de um líder é tipicamente associada à confiança. Possuir uma boa reputação aumenta a probabilidade de os seguidores confiarem nos líderes e classificarem suas intenções como positivas (HALL et al., 2004).

A reputação de um líder pode influenciar significativamente o desenvolvimento da confiança dos stakeholders. As organizações, ao menos em teoria, impõe a prestação de contas aos líderes usando mecanismos de governança corporativa (EISENHARDT, 1989). Muitos altos executivos, por serem considerados confiáveis, acabam lidando com um sistema de prestação de contas meramente ilustrativo. A reputação é um ativo pessoal valioso, ela pode ser utilizada para explicar um comportamento apropriado. Especificamente, os líderes tendem a não querer arriscar sua reputação envolvendo-se em comportamentos ilegais ou ilícitos. O modelo do conceito social de confiança argumenta que os indivíduos tendem a não recriminar o comportamento inapropriado quando o líder é considerado confiável. Em contextos em que a confiança é alta e a prestação de contas é baixa, as organizações podem acabar criando um ambiente propício a comportamentos inapropriados dos líderes. A reputação dos líderes, a confiança e a responsabilização em relação à prestação de contas podem facilitar a performance e a efetividade em alguns casos, porém podem também permitir a demonstração de um comportamento antiético e ilegal (HALL, 2004).

Apesar de a reputação ser um construto frequentemente mencionado nos estudos organizacionais, poucos autores se preocuparam em defini-lo. Uma definição da 
reputação pessoal apropriada para a reputação da liderança foi apresentada por Ferris (2003). Para esse autor, a reputação é uma percepção de identidade que reflete uma combinação de características pessoais salientes, desempenho, comportamentos e imagens, demonstrados durante um período e observados diretamente ou reportados por fontes secundárias. A reputação da liderança é uma identidade percebida que serve para reduzir a incerteza quanto à expectativa de um comportamento futuro do líder. Os líderes com uma boa reputação são vistos como altamente confiáveis, são menos monitorados, são menos exigidos em relação à prestação de contas do que líderes com baixa reputação (AMMETER et al., 2002).

A rede de relacionamentos da qual um indivíduo faz parte pode ser uma fonte da sua boa reputação individual. A reputação exerce influência na autoestima, na identidade social, no comportamento individual e nas interações sociais. Considerando que os indivíduos compartilham suas impressões de outros indivíduos uns com os outros, essas impressões se consolidam em impressões coletivas, que influenciam as atitudes, expectativas, escolhas e ações dos membros de uma rede de relacionamentos. A reputação de um líder é um produto e é também definida por suas relações sociais. A experiência pessoal sobre o comportamento do outro se acumula e pode ser consistente ou inconsistente com a reputação, o que pode fortalecer a reputação por meio da sua legitimação ou redefini-la para um estado de inconsistência em relação à expectativa de comportamento. Quando consideramos a reputação da liderança como algo socialmente construído, é importante ressaltar que o líder pode ter múltiplas reputações, cada uma sinalizando a probabilidade de um tipo de comportamento esperado para cada contexto social. Certas situações reforçam o desenvolvimento e a manutenção da reputação externa de um líder e da sua reputação interna (GOULDNER, 1960).

Diferentes qualidades, recursos e características dos indivíduos, combinadas em vários níveis e baseadas em diferentes contextos, contribuem para a reputação do líder e podem ser consideradas como antecedentes da sua reputação. Essas qualidades podem ser divididas em três categorias: 1) capital humano, que é o conhecimento, as credenciais e as habilidades que um indivíduo adquire como resultado do seu investimento em educação e treinamento. A idade/experiência pode ser considerada como um capital humano valioso; 2) capital social, que é baseado nos recursos individuais que uma pessoa adquire por conhecer outros e por sua identidade social, que resulta em benefícios tangíveis; 3) estilo de liderança, que pode variar enormemente, de acordo com a personalidade, as normas culturais e as situações. $\mathrm{O}$ estilo de liderança 
refere-se à maneira pela qual o comportamento é expresso, mais do que o comportamento em si. Ele reflete a inteligência, a personalidade e a competência social e política (HALL et al., 2004).

Schriesheim et al. (2001) sugerem que o clima político, as diferenças individuais, a reputação do líder e os índices de performance da liderança são construtos que, além de servirem como uma extensão da competência política, demonstram a natureza não linear, a dependência do tempo e a característica de multinível da teoria da competência política, a qual pode ser um importante indicador da reputação pessoal e do poder organizacional. A autoridade formal das lideranças organizacionais não lhes garante suporte em suas decisões. Tanto o desempenho quanto a equidade processual são necessários para legitimar a liderança. A reputação de um profissional é composta pelas qualidades e ações nas quais os outros o reconhecem. As pessoas podem ter mais de uma reputação, de acordo com o ambiente em que estão inseridos: empresa, família, grupo de amigos, no entanto, independentemente do ambiente, a reputação será um diferencial na habilidade de influenciar os outros. A reputação é um termo neutro, no entanto, é frequentemente utilizado associado a termos como prestígio e status, que denotam uma visão positiva que qualifica o termo (FERRIS et al., 2005).

A teoria sobre a troca social é uma das abordagens mais úteis para a compreensão e o entendimento do comportamento na organização. Os pesquisadores entendem que a troca é um elemento relevante para o estudo do comportamento por lidar com a distribuição de recursos (CROPANZANO; MITCHELL, 2005; FARRELL; PETERSON, 1982). Alguns autores argumentam que o comportamento político é uma simples extensão do interesse próprio do líder e que talvez seja possível dizer que o interesse próprio e o coletivo não sejam mutuamente excludentes, ou mesmo dizer que os líderes que atuam no espaço político para o benefício dos liderados o fazem pressupondo um suporte recíproco. Esse argumento é consistente com os princípios da teoria de troca social. No entanto não é possível afirmar que o fornecimento de recursos aos liderados por meio do suporte político sempre traga resultados positivos, como o suporte recíproco. Diferenças individuais podem ditar a natureza da troca e seus resultados (CROPANZANO; MITCHELL, 2005). Alguns autores apontam possíveis direções para estudos de assuntos ainda pouco explorados sobre o tema, como o fato de o fornecimento de recursos ao liderado poder significar que esses recursos podem ficar menos acessíveis a outros. Portanto, ao mesmo tempo em que a reputação desse líder aumenta para o grupo de seus liderados, na visão de pares ou dos liderados dos pares, 
essa reputação pode ser abalada, se os atos do suporte político impedirem que outros líderes consigam oferecer o mesmo aos seus liderados (ELLEN, 2014). A competência política do líder, na percepção do par, pode, ao mesmo tempo, proporcionar resultados positivos, como coalizões para conquistas políticas a serem obtidas com os superiores hierárquicos, como também significar resultados negativos devido à competição de interesses, seja pela escassez de recursos, seja pelas oportunidades de carreira, entre outros fatores. Estudos mostram que as pesquisas em política organizacional atuais apresentam um foco mais exclusivo nas ações dos políticos, com pouca atenção aos eleitores ou ao público de interesse (LEPISTO; PRATT, 2012).

\subsubsection{Atribuição de legitimidade}

Um indivíduo, ao longo de sua vida, internaliza a realidade objetiva, apropriase dela e age sobre ela modificando-a, e, na medida em que o faz, constrói um conceito sobre si próprio. Esse autoconceito precisa da confirmação de outros sujeitos que sejam significativos para ele, a fim de garantir a legitimidade dessa concepção e também de suas ações (BOCK; FURTADO; TEIXEIRA, 1999). No jogo de papéis é que são construídas as noções de legitimidade e mérito. O papel assume a conotação de função, acompanhada de um conjunto de condutas próprias, desempenhado num dado momento, e que lhe dá legitimidade. Normalmente, os papéis asseguram a conquista do poder de fazer algo em particular de forma legítima ou de se defender em uma posição em razão do mérito, ou seja, do bom desempenho do papel. Nas organizações, quando profissionais assumem posições de liderança, eles passam a se apropriar da função, precisando, no entanto, do olhar externo de outros sujeitos para garantir a legitimidade e reconhecer o mérito dos seus atos. Nesse sentido, a liderança pode ser entendida não apenas pela ocupação de uma posição hierárquica, mas por um conjunto de comportamentos e de autoridade que é construída na relação entre indivíduos pelo respeito, pela admiração e pelo exemplo, ou seja, a posição na hierarquia não é suficiente para garantir a legitimidade da liderança (VIEIRA et al., 2010).

A legitimidade foi concebida como o compartilhamento de normas ou princípios sociais que conduzem a uma distribuição de poder dentro das relações sociais. As autoridades tradicional e legal não servem como base para legitimar a liderança corporativa no ambiente empresarial. Os teóricos políticos reconhecem que os 
acordos e pactos permitem a regulação entre as contradições permanentes do conteúdo social e da forma política (KIRCHHEIMER, 1969).

A legitimidade é concebida como uma norma social compartilhada ou como princípios que conduzem uma distribuição de poder dentro das relações sociais. A legitimidade de um líder refere-se ao nível em que outros acreditam que ele mereça gerir, ordenar, demandar suas ações e exercer influência. Os liderados conferem ao líder uma aceitação voluntária e uma aprovação da autoridade. A legitimidade implica qualidades como credibilidade, confiança e lealdade (HOLLANDER, 1993; CHOI; MAI-DALTON, 1999).

O papel da legitimidade na efetividade das autoridades e lideranças é um tema central na literatura da psicologia. Já que ele pode moldar o comportamento voluntário dos seus membros de um grupo. A liderança baseada em premiação, coerção ou em ambos é frequentemente ineficiente. Quando as autoridades são vistas como ilegítimas, elas precisam justificar cada decisão tomada ou usar premiações, ameaças e punições. Por outro lado, quando consideradas legítimas, as lideranças conseguem ter mais liberdade para buscar políticas que sejam vantajosas no longo-prazo para o interesse do grupo. As lideranças são, normalmente, requisitadas para tomarem decisões em situações complexas, em que dificilmente todos conseguirão conquistar o que desejam. Consequentemente, as autoridades, permanentemente, acabam fornecendo resultados indesejados ou negativos. Por causa dessas condições, seria de se esperar que a legitimidade dessa autoridade fosse baixa. No entanto estudos mostram que nem sempre isso acontece, muitas autoridades encontraram forte apoio em seus grupos. $\mathrm{O}$ reconhecimento do valor da legitimidade mostra a importância de as lideranças saberem conquistar e manter sua legitimidade. Em contrapartida, estudos mostram que a legitimidade de uma ampla variedade de autoridades sociais (legal, política, religiosa e administrativa) tem declinado nas décadas recentes. As lideranças atuais e futuras já não conseguem garantir sua legitimidade com base na autoridade concedida, pelo contrário, cada vez mais a conquista da legitimidade é um processo autêntico, que demanda manutenção constante (TYLER, 1990).

Hollander e Julian (1978) estudaram a legitimidade da liderança como uma variável que sintetiza parte do processo que afeta a relação do líder com seus liderados. Essas variáveis são: 1) a fonte de autoridade da liderança, que pode ser por meio de nomeação ou eleição; 2) a percepção de competência e da motivação e 3 ) o sucesso ou fracasso em produzir resultados desejados para o grupo. Em um estudo sobre a fonte de 
autoridade das lideranças, os autores testaram a aceitabilidade dos grupos em relação às lideranças nomeadas e às lideranças eleitas em momentos de falha e sucesso. Eles verificaram que líderes eleitos foram vistos por seus seguidores como mais sensíveis às necessidades dos seguidores, mais interessados nas tarefas do grupo e mais competentes do que líderes nomeados. Eles foram considerados ainda como os profissionais mais prováveis a se tornarem futuros líderes (BEN YOAV; HOLLANDER; CARNEVALE, 1983). A conclusão do estudo de Hollander e Julian (1978) foi que a fonte de autoridade está relacionada com a variável sucesso/falha. A falha, muitas vezes, é vista como uma crise. Ao lidar com ela, o líder eleito aumenta o seu poder de influência e aceitação do grupo. No entanto os experimentos mostraram que o ponto alto de influência de um líder eleito ocorre na segunda fase após o momento "crise", e, mesmo assim, essa é uma fase curta. Se o grupo não visualizar sinais de grande sucesso, o líder será deposto, mesmo depois do aumento da sua influência pós-crise. Nos episódios de crise, líderes perdem prestígio mais rapidamente que não líderes, por serem mais responsabilizados pelos resultados do grupo. A legitimidade de um líder em uma situação emergente está pautada na percepção dos membros do grupo sobre o "potencial do líder" durante as interações com o grupo. O comportamento de interação do líder com o grupo é um fator determinante para a percepção desse grupo sobre as habilidades e motivações do líder. A legitimidade do líder e a aceitação da sua influência pelos membros do grupo são baseadas nessas percepções. Esse estudo de Hollander e Julian (1978) encontrou que a alta frequência de interação (quantidade) muitas vezes importa mais que a sua qualidade, ou seja, a quantidade da interação verbal com os participantes foi determinante para as avaliações de competência, confiança, influência e contribuições para o objetivo do grupo. No entanto a qualidade tem um papel importante também na percepção socioemocional do líder e no julgamento da sua competência. A competência ou habilidade, combinada com uma grande quantidade de participação, foi considerada como muito valorizada pelos membros do grupo, ao menos no estágio inicial do desenvolvimento de um grupo em relação ao aspecto socioemocional da liderança. As pessoas que interagem com mais frequência tendem a receber um aval inicial dos membros do grupo para o papel da liderança.

Uma característica principal dos grupos e organizações é que eles possuem regras e autoridades (lideranças). Segundo Tyler e Lind (1992), essas regras e as autoridades são importantes para a efetividade dos grupos, uma vez que elas contribuem para a manutenção da ordem social por meio de regulamentação da distribuição de 
recursos, oportunidades, resolução de conflitos e de reforço das regras. Nos períodos de crise e dificuldades, os grupos criam e empoderam as lideranças em busca da resolução dos problemas e da manutenção do grupo. No entanto a criação de uma liderança não significa a resolução automática dos problemas. Essas lideranças precisam ser efetivas e, para serem efetivas, elas precisam influenciar o comportamento dos membros do grupo. A observação de grupos feita por Tyler e Lind (1992) mostrou que as lideranças são efetivas na influência do comportamento dos membros do grupo em certo nível.

Os estudos de Psicologia sobre as pessoas dentro da organização mostram que existe uma obediência disseminada em relação às regras organizacionais e às decisões tomadas pelas lideranças. Não é surpresa que os membros de um grupo sigam as regras em razão da premiação, complacência e punição pela desobediência. No entanto é interessante observar também que as pessoas se comportam de acordo com as regras em situações em que não há premiação ou punição (TYLER, 1997). Em vez disso, as pessoas têm valores sociais e o sentimento de obrigação internalizada que as fazem seguir as regras sociais, ou seja, elas obedecem voluntariamente. As regras sociais acabam fazendo parte de um sistema de motivações que guia o seu comportamento mesmo na ausência de autoridades externas (HOFFMAN, 1977). Os estudos de Milgran (1963) mostraram que a obediência à autoridade ocorre mesmo quando as pessoas têm que tomar atitudes que sejam pessoalmente aversivas.

A legitimidade foi definida por estudiosos da ciência política como a crença de alguns membros da sociedade de que existem razões adequadas para obedecer voluntariamente aos comandos de uma autoridade (FRIEDMAN, 1970). A legitimidade é importante porque a percepção de obrigação envolvida na legitimidade leva a um comportamento de deferência (TYLER, 1990). Zelditch e Walker (1984) consideram que o consentimento é uma condição necessária para a estabilidade de um sistema de poder. A legitimidade é importante porque dá origem ao consentimento. A autoridade legítima é mais eficiente que a coercitiva ou a induzida (WRONG, 1980).

A legitimidade de um líder é baseada na sua competência, na sua habilidade e no seu comprometimento para alcançar as metas do grupo. Os indivíduos esperam um alto nível de performance de um líder legítimo. Hollander e Julian (1978) enfatizam as características pessoais, como competência e motivação, assim como associações institucionais como fontes de legitimidade. A literatura sobre estabilidade nos sistemas políticos enfatiza que a legitimação da autoridade é baseada na habilidade de satisfazer as demandas dos stakeholders. Os membros de uma sociedade esperam que o poder 
político seja exercido de forma a ajudar a satisfazer os seus interesses materiais e ideais (LIPSET, 1960).

Para Chakravarthy (1997), a legitimidade corporativa das lideranças pode ser medida em termos comerciais e sociais. A legitimidade comercial refere-se ao suporte que o grupo de altos executivos recebe dos shareholders, clientes e fornecedores. Essa é uma medida que avalia quão bem esse grupo gerencia as atividades econômicas. A legitimidade social, por outro lado, é o grau de comprometimento que esse grupo consegue gerar entre os trabalhadores da empresa e as comunidades locais no cumprimento da missão e das estratégias da empresa. Enquanto os stakeholders comerciais têm uma associação mais transacional com a empresa, os shareholders sociais têm uma relação mais emocional. Ao tentar melhorar sua legitimidade comercial, os líderes podem gerar danos irrevogáveis na sua legitimidade social. A legitimidade social, uma vez perdida, pode ser muito difícil de ser reconstruída (FREEMAN; ROGERS, 1994).

Um aspecto que interfere na atribuição da legitimidade é que, quanto mais alto o nível hierárquico, maiores e complexos serão os problemas. A complexidade de um problema encontrada na realização de uma tarefa, um projeto ou uma estratégia é uma função de variáveis que envolvem seus números, sua clareza ou ambiguidade, a velocidade com que mudam e, de maneira geral, a extensão com que se apresentam distintas e complexas. Os maiores problemas enfrentados por um CEO de uma grande corporação são infinitamente mais complexos dos que os encontrados por um profissional de "chão de fábrica". Profissionais que ocupam o mesmo nível hierárquico tendem a ter autoridade similar e mesmo nível salarial. É essa mudança na qualidade e não apenas na quantidade do trabalho do gestor que faz com que a aceitação pelos subordinados seja natural e apropriada. A aceitação natural e apropriada é que dá legitimidade aos líderes. Por outro lado, se essas camadas forem muito estratificadas e baseadas apenas em questões salariais e não cognitivas, os subordinados tendem a ver seus chefes como muito próximo e a identificar seu chefe "real" como aquele de um nível superior (JAQUES, 1991).

A legitimidade tem sido reconhecida como um processo fundamental para as organizações. A legitimidade como um processo social pode ser analisada em diferentes níveis. Duas grandes áreas da sociologia articulam esse conceito: a) a abordagem da Psicologia Social, que focaliza a legitimação por meio das características de status pessoal, posicionamento perante o grupo, estruturas e práticas de autoridade 
organizacional e estratificação de grupos, e b) a abordagem da Teoria Institucional, que, na literatura organizacional, examina a legitimidade por meio da avaliação das formas, práticas e estratificações organizacionais. Essa abordagem trata da importância da legitimidade para as organizações permanecerem viáveis, conquistarem lealdade de seus clientes e apoio às suas decisões e políticas. Nas duas áreas, o processo de legitimidade é o pilar das teorias que tentam explicar o comportamento em grupo e nas organizações, respectivamente. Uma preocupação comum nas várias abordagens sociais da legitimidade é a ênfase na criação e legitimação de um novo objeto social, enquanto outras abordagens preocupam-se mais fortemente com a manutenção da legitimidade de um objeto social existente, além da atenção dada às consequências da legitimidade tanto nos grupos quanto nas organizações e níveis sociais. Johnson, Down e Ridgeway (2006), ao analisar essas duas abordagens, concluíram que a construção de um objeto social como legítimo depende de uma crença consensual sobre como as coisas deveriam ser feitas ou são feitas tipicamente, criando, dessa forma, uma forte expectativa do que deve acontecer nas situações locais. Neste trabalho, será dado enfoque à abordagem da legitimidade segundo a lente da psicologia social, por esta tratar da temática em um nível individual, levando em consideração a atuação de atores como líderes, que é o tema deste trabalho.

Os psicólogos sociais têm usado o construto da legitimidade para explicar a estabilidade e as reações comportamentais de uma ampla gama de entidades sociais, incluindo indivíduos (líderes), procedimentos de grupo, regras, normas e hierarquias sociais. Primeiramente, grande parte das pesquisas nessa área definiu a legitimidade como a deferência ou obediência a autoridades e regras. Essa abordagem da legitimidade deriva do conceito de poder legítimo de French e Raven (1959), o qual trata de uma forma de poder que decorre do senso dos subordinados de que uma autoridade tem o direito de governar. Por outro lado, Trost (2011) defende que esse tipo de poder (sentimento de obrigação) pode ser, na verdade, o resultado positivo de um julgamento de legitimidade. Para esse autor, a percepção e a crença que fundamentam o julgamento de um líder como legítimo produz a percepção de intitulação do poder do líder. Essa percepção de intitulação de poder, por sua vez, produz o sentimento de obrigação no cumprimento da demanda do líder. Essa distinção é importante, já que o sentimento de obrigação pode vir de outras fontes que não a da legitimidade, por exemplo, quando o descumprimento pode gerar um resultado negativo para outros. 
A Psicologia Social propôs dois modelos para especificar o conteúdo do julgamento da legitimidade em um nível individual. O Modelo Instrumental trata da reação dos indivíduos aos aspectos instrumentais das suas experiências com entidades/autoridades sociais. A perspectiva instrumental da legitimidade prevê que as entidades/autoridades serão julgadas como legítimas quando atenderem aos interesses materiais dos indivíduos ou quando facilitarem o alcance de metas e resultados definidos e internalizados por indivíduos ou pelo grupo. Portanto a percepção e a crença do julgamento da legitimidade instrumental estão relacionadas à percepção de efetividade, eficiência e utilidade da entidade/autoridade. Em contraste, o Modelo Relacional defende que a legitimidade é alcançada quando a entidade/autoridade confere ao indivíduo respeito, dignidade, status dentro do grupo e sentimento de filiação, ou seja, quando oferece identidade social e reforça o sentimento de autoestima do indivíduo. Exemplos da percepção ou crença da dimensão relacional estão ligados aos conceitos de justiça, benevolência e comunalidade. Trost (2011) alerta para a importância de distinguir legitimidade de justiça e equidade. Para ele, a justiça e a equidade constituem uma das dimensões que permeiam o julgamento da legitimidade individual.

Um dos primeiros trabalhos a contrastar os dois modelos foi o de Tyler (1997). No artigo sobre a psicologia da legitimidade, Tyler (1997) mostra três abordagens da psicologia que sugerem que ter legitimidade influencia o grau de efetividade ou não das autoridades de um grupo, ou seja, ele relaciona a legitimidade na mente dos membros do grupo à habilidade das autoridades de liderarem esse grupo. A primeira abordagem examina a autoridade do ponto de vista das autoridades. Ela argumenta que a efetividade do exercício da autoridade depende, em grande parte, das atitudes e dos valores dos membros do grupo, pois eles é que governam o comportamento voluntário das pessoas. Para as autoridades, é importante obter um poder discricionário que lhes permita atenuar as diferenças de interesses e valores sem causar uma disputa entre as partes. A segunda abordagem analisa a autoridade sob a perspectiva dos membros do grupo em desvantagem. Essa perspectiva sugere que a natureza do comportamento de resposta às desigualdades individuais ou de grupo em relação à distribuição de recursos e oportunidades serão moldadas pela visão da legitimidade ou não da autoridade. Diferenças na alocação de recursos e oportunidades não provocam raiva quando a autoridade ou a instituição é vista como legítima. A tendência das autoridades de sofrerem resistência pelos membros do grupo dependerá da sua legitimidade ou da 
legitimidade das regras e da instituição que elas representam. A terceira abordagem trata da obediência à autoridade e menciona que normalmente as pessoas de um grupo inicialmente aceitam a legitimidade de uma autoridade existente, no entanto uma mudança social requer que as pessoas redefinam a situação como "ilegítima", ou seja, antes de as pessoas quebrarem uma regra social, elas acabam redefinindo suas crenças e adotam a percepção de ilegitimidade do sistema.

Um ponto importante para o entendimento do desenvolvimento e manutenção da legitimidade se baseia nos fundamentos da psicologia da legitimidade. Tyler (1997) fez uma revisão que explorou e contrastou dois modelos psicológicos da legitimidade: Resourced based instrumental model e Identity based relational model. Segundo esse autor, as discussões passadas sobre legitimidade eram vistas de uma perspectiva instrumental, no entanto, nesse estudo, ele evidenciou que uma importante motivação para a deferência voluntária às autoridades envolve julgamentos relacionais sobre o tratamento oferecido por essas autoridades. Para ele, as teorias de legitimidade devem considerar ambos os aspectos relacionais e instrumentais. Algumas evidências que dão suporte ao papel dos julgamentos relacionais são apresentadas por ele: 1) as pessoas são influenciadas por como são tratadas pelas autoridades, independentemente da sua avaliação sobre o que elas recebem ou não dessas autoridades; 2) as pessoas são mais afetadas pelo tratamento que recebem das autoridades quando elas são afiliadas ao mesmo grupo da autoridade; 3) a identificação com o grupo da autoridade tem mais peso que o tratamento oferecido por elas; 4) no julgamento da legitimidade, as pessoas se importam mais com a integridade da autoridade do que com sua competência.

A conclusão de Tyler (1997) é que as pessoas tendem a ter deferência a uma autoridade quando elas se sentem membros valorizados e respeitados do grupo que essa autoridade representa e quando elas confiam nos motivos e na neutralidade da autoridade. A perspectiva relacional da legitimidade sugere que o entendimento da legitimidade deve avaliar as conexões sociais de uma comunidade. Pessoas socialmente conectadas desenvolvem laços sociais, o que faz com que elas se preocupem com os outros membros do grupo e valorizem sua opinião e julgamento. As pessoas internalizam os valores do grupo como seus próprios valores, o que contribui para a aceitação das decisões tomadas pela autoridade do grupo. Essas duas razões esboçam os benefícios das conexões sociais para as autoridades com o grupo que elas representam. Existem três elementos do conceito relacional que são importantes para o julgamento da legitimidade: confiança, respeito interpessoal e neutralidade. $O$ julgamento das 
intenções presentes permite às pessoas predizerem o futuro, uma vez que a interpretação das intenções mostra o caráter da pessoa que é tipicamente vista como tendo uma característica estável e imutável. Por essa razão, o julgamento da atitude das autoridades depende do julgamento das suas intenções de benevolência. Se as pessoas acreditarem na intenção e tentativa das autoridades de serem justas e neutras, elas confiarão em seus motivos e desenvolverão um comprometimento no longo prazo. Alguns estudos sugerem que o tratamento polido, com dignidade e respeito, demostra o respeito aos direitos e o status na sociedade e aumenta o sentimento de justiça. $\mathrm{O}$ interessante é que nenhum dos três elementos do conceito relacional está diretamente relacionado à solução específica de algum problema ou disputa.

Três preocupações foram identificadas em estudos sobre autoridades de grupos como particularmente significantes quanto à relevância e identidade das autoridades: 1) neutralidade das autoridades; 2) benevolência ou confiabilidade dos seus motivos; 3) reconhecimento que trata do respeito interpessoal e da dignidade do tratamento interpessoal - preocupações relacionais (TYLER, 1990; TYLER; LIND, 1992).

A análise da legitimidade com enfoque relacional trata de três elementos da legitimidade: a disposição de aceitar as decisões voluntariamente, a obediência às regras e uma avaliação favorável das autoridades. Já o enfoque da identidade trabalha com a premissa de que as pessoas querem ter bons sentimentos sobre si mesmas. As interações com os outros não ocorrem apenas em razão da troca de recursos, mas também para definir e desenvolver os aspectos sociais que contribuem para a definição do próprio indivíduo. Por essa razão, as pessoas se preocupam com o seu status social, com sua reputação e com como são tratadas. Apesar de as pessoas se preocuparem, na avaliação dos líderes, mais com a integridade e o cuidado apresentados pelas autoridades do que com sua própria competência, pode haver circunstâncias em que a competência se torne uma questão central. Portanto pode-se concluir que os aspectos relacionais e de identidade não são as únicas formas de avaliar a legitimidade. O aspecto instrumental é também uma forma muito importante, além de outros elementos. Zelditch e Walker (1984) distinguem dois elementos da legitimidade - a propriedade e a validade. A propriedade envolve a percepção de que a autoridade é apropriada, enquanto a validade trata da sensação de que os outros vão agir como se a autoridade fosse legítima. Esse trabalho concluiu que, nos casos de conflito entre autoridades e subordinados, o impacto dos aspectos relacionais é mais forte e que o conteúdo do julgamento da legitimidade deriva das preocupações com a identidade individual. Para Trost (2011), tanto o modelo 
instrumental como o relacional servem como base de diferentes dimensões da percepção da legitimidade que podem impactar simultaneamente o julgamento geral da legitimidade, permitindo aos pesquisadores avaliarem os aspectos do contexto social e das características dos avaliadores no processo de julgamento da legitimidade, ou seja, os modelos não são mutuamente excludentes.

Recentemente, a Psicologia Social incluiu a dimensão da moral para compreensão do julgamento da legitimidade. Os psicólogos sociais argumentam que a moralidade é uma dimensão importante da avaliação geral das entidades/ autoridades sociais. Uma entidade é percebida como legítima nessa dimensão quando o julgamento do avaliador é consistente com sua percepção moral, ética e de integridade (TROST, 2011). Para Leach, Ellemers e Barreto (2007), enquanto a abordagem relacional e a moral podem ser vistas de forma consistente com o conceito único de benevolência, as duas são abordagens distintas. Em uma série de estudos, foi demonstrado que a abordagem instrumental, a relacional e a moral constituem fatores distintos na avaliação da legitimidade. Em muitas circunstâncias, as preocupações morais são mais importantes que as demais. Leach, Ellemers e Barreto (2007) ressaltam que as três abordagens não são mutualmente excludentes, podendo ser avaliadas simultaneamente e ter algum grau de sobreposição.

A abordagem da Psicologia Social que lida mais explicitamente com o processo no qual um objeto (entidade/ autoridade) é construído como legítimo é a descrição de Ridgeway e Berger (1998) da legitimação por meio do status interpessoal nas hierarquias. Essa abordagem considera que os atores têm crenças referenciais sobre categorias sociais ou tipos de pessoas (por exemplo, aqueles com mais status social no grupo, os mais habilidosos e os mais bem sucedidos) que tipicamente ocupam uma posição relevante na influência interpessoal na hierarquia social. Essas crenças referenciais são crenças descritivas sobre a realidade social, sobre a forma como as coisas são, que os atores presumem que sejam amplamente compartilhadas e, portanto, socialmente válidas, independentemente se eles aprovam ou não tais crenças. Quando essas crenças referenciais são evocadas em uma situação pela característica dos atores presentes, eles criam expectativas implícitas para os tipos de atores sociais que se tornarão influentes na situação. Pelo fato de os atores terem essa expectativa e de assumirem que os outros presentes também a têm, haverá uma probabilidade de que essa crença seja tratada como legítima, fazendo com que a pessoa exiba gestos de deferência honorífica ao ator influente (por exemplo, louvor respeitoso, gestos de 
deferência verbais e não verbais). Se esse gesto de deferência for validado pela reação dos outros na situação, seja por meio de comportamento similar ou simplesmente por não contradizerem o comportamento, então a crença referencial será legitimada. Para Ridgeway e Berger (1998), a legitimidade é um processo altamente implícito, no qual uma ampla crença cultural é compartilhada com a sociedade envolvida, criando expectativas fortes a respeito do que é provável ocorrer nas situações locais. Fortes expectativas indicarão o comportamento de aceitação e a aparente concordância consensual que demonstrarão a legitimidade dessas crenças tornando-as normativas.

\subsubsection{Desenvolvimento na carreira}

Após a década de 1980, o conceito de carreira relacionado a uma organização para a vida toda, ascensão por tempo de empresa e valorização do comportamento do "funcionário padrão" deixou de prevalecer nas organizações. O aumento da competitividade fez com que a estrutura das empresas se tornasse mais achatada, que as pessoas fossem avaliadas por suas competências e o alcance de posições de topo deixasse de ser sinônimo de sucesso (DUTRA, 2010). As organizações mais planas acabam tendo pouco espaço para as promoções tradicionais. No entanto é importante observar que as promoções não deixarão de existir, mas outras formas de reconhecimento irão crescer em importância, como designar um profissional para uma tarefa interessante, desafiadora e que lhe traga prestígio, ou para assumir projetos em grupo que, apesar de não representarem uma promoção efetivamente, serão vistos como uma forma de reconhecimento e premiação (FERRIS; DAVIDSON; PERREWÉ, 2010).

Em razão das novas demandas do mundo contemporâneo, o ambiente de trabalho se modificou, alterando também o conceito de carreira, tanto para profissionais quanto para as organizações. Para Dutra (2004), a avaliação da carreira passou a se desvincular do cargo, de promoções ou de status profissional e passou a ser mais condizente com a percepção de crescimento profissional: a carreira como desenvolvimento. $\mathrm{O}$ desenvolvimento profissional é a capacidade de assumir atribuições e responsabilidades em níveis crescentes de complexidade. Os diferentes níveis de liderança constituem trilhas de desenvolvimento. Cada trilha representa uma passagem significativa que não se restringe a uma ação formal de desenvolvimento, mas sim constitui um processo continuado e composto por múltiplas ações que se vinculam aos desafios da liderança. Alguns desafios passam a fazer parte dessa trilha, como gerenciar 
áreas fora da sua experiência, aumentar a habilidade de comunicação, uma vez que esta se torna necessária à penetração em mais níveis. Em alguns casos, ocorre também o aumento das distâncias do ponto de vista geográfico, quando se exigem ainda maior autonomia e responsabilidade, mudanças nas competências e na utilização do tempo, valores de trabalho e visão dos negócios e abertura para o desconhecido (CHARAN; DROTTER; NOEL, 2010).

Ao tratar a carreira como a sucessão de degraus de complexidade, alguns desajustes entre a realidade organizacional e o sistema formal de gestão de pessoas podem ocorrer, conforme alerta Dutra (2010). Esse autor verificou, por meio de pesquisas realizadas em empresas brasileiras, que raramente os programas de desenvolvimento estimulam nas pessoas o confronto com situações mais exigentes. $\mathrm{O}$ descompasso entre a incorporação de atribuições e responsabilidade por profissionais juniores e a avaliação e sinalização da organização sobre o seu desenvolvimento dificulta sua adaptação e credibilidade para a promoção para o próximo nível ou pode fazer com que profissionais assumam precocemente uma responsabilidade de maior nível de complexidade.

As transições na carreira das lideranças ocorrem em razão das aspirações pessoais, motivações, necessidades, expectativas e imposições da organização e sociedade (LONDON; STUMPF, 1982). A avaliação objetiva do sucesso é realizada com base em parâmetros mensuráveis externa e objetivamente. Os parâmetros mais comuns são as recompensas financeiras, os níveis hierárquicos e o número de promoções (STURGES, 1999). Ao desenvolver e manter líderes preparados para os próximos níveis hierárquicos, a organização ganha agilidade e qualidade no longo prazo e consegue responder às mudanças e às ameaças do ambiente. No presente estudo, o desenvolvimento na carreira foi analisado sob a perspectiva individual, os entrevistados avaliaram se a competência política contribuiu para sua carreira, ou seja, a questão do sucesso e desenvolvimento na carreira foi mensurada pela percepção individual dos profissionais em relação a sua própria carreira.

A carreira de gestão ainda é, em muitas organizações, a única alternativa de desenvolvimento real dentro da empresa. Muitas vezes, tanto a empresa quanto os profissionais acabam vendo os cargos de gestão como uma premiação ou como a única trajetória possível. Uma das consequências disso é que, na maioria das vezes, muitos profissionais sem vocação para a gestão acabam assumindo esse papel, e as empresas acabam perdendo bons técnicos e ganhando péssimos gestores. Para Dutra (2010), a 
transição de uma carreira técnica para uma carreira gerencial nem sempre é interpretada pelas organizações como migração de carreiras de naturezas diferentes. No entanto, quando uma pessoa deixa uma função técnica para assumir uma posição de gestão, ela passa por uma transição de identidade profissional. Isso porque o que caracteriza o trabalho de um gestor é o fato de ter que gerenciar recursos escassos e, portanto, estar na arena política da organização.

Dutra (2016), em seus estudos sobre liderança, identificou duas arenas políticas nas organizações, a arena do nível tático e a do nível estratégico. A arena política do nível tático é caracterizada por ser um espaço de disputa de recursos escassos orçamento, investimentos, massa salarial, espaço físico etc. É nessa arena que ocorrem a formação das regras de convivência e de acesso aos recursos escassos; a criação de regras de relacionamento entre áreas e com parcerias externas.

Já a arena política do nível estratégico apresenta-se como um espaço de discussões sobre o futuro da organização; parcerias estratégicas; relacionamento com stakeholders; influência no ambiente/contexto em que a organização se insere.

Dutra (2016) concluiu que existem disputas contínuas por espaço político nas duas arenas, ou seja, busca por mais poder de influência na relação com pares, superiores, público interno e externo e parceiros. Essa migração exige muita preparação da empresa e de seus profissionais e, se for feita de forma inadequada, pode acabar gerando uma insatisfação das partes envolvidas nesse processo (DUTRA, 2010).

As competências políticas são vistas como fator crítico para a efetividade e o desenvolvimento da carreira de liderança (FERRIS et al., 2000). As organizações atuais, cada vez mais, demandam competências sociais de suas lideranças para gerirem as constantes mudanças no ambiente de trabalho. As competências políticas parecem corresponder a essas necessidades. Ao assumir um cargo de gestão, o profissional terá, necessariamente, que atuar na "arena política" da organização. No entanto nem todos os profissionais têm vontade ou experiência para realizar tal tarefa, sendo, portanto, fundamental que eles se desenvolvam para lidar com essa nova demanda.

Um estudo elaborado por Judge e Bretz (1994) mostrou a influência do comportamento político como antecessor do sucesso extrínseco e intrínseco na carreira. Essas transições de carreira representam uma série de desafios para as lideranças e para as organizações. O processo de desenvolvimento e promoção de lideranças é complexo e envolve não apenas as questões técnicas, mas disputa por controle e poder entre pares, seleção e preparação de um sucessor, influências institucionais e do ambiente externo, 
contratos psicológicos, entre outras questões. Para que a promoção da liderança seja bem-sucedida, é necessário que ela consiga se legitimar na nova posição, apesar das dificuldades e obstáculos. Esse contexto, certamente, exige articulação política e competências políticas.

A promoção está entre as decisões mais políticas de uma organização. Parte da dificuldade está relacionada à falta de clareza e especificidade dos requisitos e critérios da promoção. Os gestores, normalmente, buscam pessoas que melhor se encaixam ou que apresentam o melhor potencial. No entanto esse conceito de se enquadrar melhor e de potencial pode ser diferente para cada gestor. A maior parte do tempo, a definição está relacionada à similaridade com as características e qualidades do gestor em questão, o que nem sempre é positivo para as organizações em razão da falta de pensamento divergente.

Algumas teorias são importantes para melhor compreensão do sistema de promoção nas organizações e o desenvolvimento na carreira. É sabido que, se um profissional tem os requisitos para alcançar um próximo nível de complexidade, a chave para ser promovido é ser notado (FERRIS; DAVIDSON; PERREWÉ, 2005). A Teoria da Sinalização assume que, para reduzir a ambiguidade e influência das crenças dos observadores, os indivíduos devem mandar sinais para outras pessoas como forma de transmitir informações sobre suas ações, intenções e habilidades. Profissionais politicamente habilidosos sinalizam sua efetividade no trabalho e características pessoais desenvolvendo uma relação forte com seus superiores e aumentando sua reputação pessoal (SPENCE, 1974).

Outra teoria importante relacionada ao desenvolvimento na carreira é a Teoria da Troca Social, que foca a obrigação e reciprocidade entre entidades (BLAU, 1964). Profissionais politicamente habilidosos tendem a desenvolver uma relação de alta qualidade com seus superiores. Os superiores que se beneficiam dessa relação de qualidade tendem a ter um comportamento recíproco, por meio de uma avaliação positiva, boa reputação pessoal e resultados positivos na carreira (BLICKLE et al., 2011).

Já a Teoria do Capital Social (BURT, 2000; NAHAPIET; GHOSHAL, 1998) também é fundamental para explicar o papel da competência política no sucesso na carreira. Seibert et al. (2001), baseados nessa teoria, criaram a proposição e encontraram que o network e a estrutura do network contribuem para o sucesso na carreira. A estrutura de network (laços fortes ou estrutura adequada) promove sucesso na carreira 
tanto objetiva quanto subjetivamente. Os recursos sociais (contatos com pessoas de outras funções ou de cargos mais altos) acabam associando-se aos benefícios do network (acesso à informação e recursos e apadrinhamento na carreira).

Para Ferris et al. (2007), as organizações deveriam explorar formas de treinar e desenvolver as competências políticas nos seus profissionais com bom potencial. Apesar de fatores como disposição serem parcialmente responsáveis pelas diferenças nas competências políticas, eles acreditam que indivíduos poderão adquirir essas habilidades com tempo, prática, treinamento e socialização. As organizações deveriam criar experiências que facilitem esse tipo de aprendizagem, por exemplo, atividades de atuação de um papel e o uso de mentores. Para Kolodinsky et al. (2004), é provável que a cultura da organização e o grupo de trabalho tenham impacto no desenvolvimento dessa habilidade.

\subsection{Teorias sociais que contribuem para compreensão da temática}

Nessa seção foram abordadas as seguintes teorias: Teoria da Influência Social, Teoria da Troca Social, Teoria Socioanalítica em razão da sua contribuição para melhor compreensão do tema. Essas teorias tratam das interações sociais, dos processos de influência e das motivações sociais para o comportamento de influência. Acredita-se que essa discussão é relevante pelo fato de a competência política ser uma competência de efetividade social e pelo subsídio que essas teorias trazem para ampliação do entendimento da perspectiva positiva do comportamento político.

\subsubsection{Teoria da Influência Social}

De acordo com a Teoria da Influência Social, a maioria das relações interpessoais envolve algum tipo de influência social. As pessoas desejam influenciar os outros enquanto são influenciados pelos outros. Através do processo de influência, a mudança no mundo social é gerada e gerida. Como quase todos os processos, ela pode ser bem administrada ou não. Esse processo pode ser empregado para várias razões, como para aumentar o crescimento, afastar as pessoas de hábitos negativos em direções positivas, criando, assim, condições para novas oportunidades de mudança. O processo de influência social é, inegavelmente, um componente central da interação social. As pessoas buscam influenciar e permitem serem influenciadas em quase todos os 
segmentos interpessoais da sua vida. O processo de influência serve para atingir múltiplas metas, como comportar-se efetivamente para construir e manter relacionamentos e para gerir o autoconceito. O entendimento de cada uma dessas metas leva a uma lógica importante para o exercício da influência e oferece uma maneira de entender muitos dos seus efeitos. Vários desses efeitos foram atribuídos a metas particulares para o atingimento da efetividade organizacional, no entanto essa atribuição não implica que apenas uma única meta esteja sendo atendida. As atribuições podem contribuir para o atingimento de mais de uma meta. A satisfação simultânea de vários objetivos aumenta os esforços e a probabilidade da tentativa de a influência ser bem sucedida. A motivação para o atingimento de uma meta pode ter uma natureza social, individual e situacional. As metas podem interagir com as situações sociais de várias formas, como a busca por aprovação social, a mudança de objetivos em razão da mudança de situação, o desejo de evitar sanções do grupo. A explicação da influência social deve considerar as características tanto do alvo de influência como do cenário e das inúmeras maneiras pelas quais eles podem interagir. As interações sociais são complexas e ricas (CIALDINI; TROST, 1998).

A influência social engloba um ciclo infinito de trocas que incita as pessoas a apresentarem-se de maneira mais positiva possível, de forma a induzir uma reação positiva no seu alvo de influência. A influência social envolve táticas utilizadas pelos indivíduos para aumentar resultados positivos e para redução de possíveis consequências negativas associadas a uma dada interação social (FERRIS; HOCHWARTER et al., 2002; FERRIS et al., 2016).

A literatura das ciências organizacionais estudou uma série de táticas de influência. Tedeschi e Melburg (1984) desenvolveram uma taxonomia para organizar diferentes táticas de influência. Segundo essa taxonomia, as táticas de influência podem ser classificadas em duas dimensões: assertiva-defensiva e tática-estratégica. Os comportamentos assertivos são iniciados pelos atores em resposta a alguma coisa, enquanto as táticas defensivas são reações que ocorrem normalmente em resposta a uma ameaça percebida. Os comportamentos táticos englobam táticas de perspectivas de curto prazo, enquanto os comportamentos estratégicos envolvem táticas de longo prazo, que possam ter implicações positivas para sua reputação pessoal. Nesse sentido, os comportamentos táticos-defensivos incluem comportamentos como desculpas, justificativas, renúncias e retratações. Já os comportamentos de táticas assertivas incluem intimidação, autopromoção, bajulação e exemplificação. Os comportamentos 
estratégicos defensivos incluem alcoolismo, desamparo aprendido, abuso de substâncias. Os comportamentos estratégico-assertivo são comportamentos orientados para a criação de uma reputação pessoal positiva (FERRIS et al., 2016).

Os empregados frequentemente se engajam em táticas de influência com seus superiores na medida em que eles podem afetar um resultado valioso. Os funcionários devem ser interpretados como participantes ativos no contexto de avaliação da performance. Vários estudos demonstraram o impacto das táticas de influência nas avaliações de performance dos empregados (KIPNIS; SCHIMDT, 1998; WAYNE; FERRIS, 1990; FERRIS et al., 2016).

Essa teoria contribui para o entendimento dessa temática, na medida em que retrata a natureza humana sob os processos de influência, uma vez que são todos influenciadores e influenciados nas interações sociais. E também por tratar de um aspecto importante dos processos de influência, que é o atingimento de várias metas simultaneamente. Por exemplo, um gestor competente politicamente usa da sua competência para influenciar a aprovação de um projeto que ele acredita que trará bons resultados para empresa, aumentará sua reputação e respeitabilidade, trará o apoio e alinhamento com um grupo de pares e outros profissionais, bonificação etc. Essa teoria mostra que nem sempre a motivação para uma ação de influência visa apenas o benefício próprio, mas que, na maioria das vezes, o comportamento de influência busca atingir objetivos múltiplos que não necessariamente se contradizem. Segundo Cialdini e Trost (1998), a satisfação simultânea de vários objetivos, inclusive, aumenta os esforços e a probabilidade da tentativa da influência ser bem sucedida. A motivação para o atingimento de uma meta foca as motivações sociais do indivíduo e as situações e diferentes contextos. As interações sociais são complexas e ricas, e a visão do interesse pessoal como a única motivação para o engajamento em ações de influência é uma forma simplista e reducionista de avaliar essa motivação.

\subsubsection{Teoria da Troca Social}

A Teoria da Troca Social é uma teoria que traz conceitos importantes e influentes para a compreensão do comportamento no trabalho. Homans (1958) apud Cropanzano e Michell (2005) apresentou um conceito de comportamento social baseado em troca. Ele introduziu a noção de que as trocas não se limitam a coisas materiais, mas que podem incluir valores simbólicos (aprovação, prestígio). Uma das premissas básicas 
da Teoria da Troca Social é que as relações, no decorrer do tempo, envolvem confiança, lealdade e comprometimento mútuo. Os indivíduos voluntariamente executam ações com a expectativa de que isso gerará uma resposta recíproca. Para tanto, as partes devem respeitar certas regras de troca, que formam uma definição normativa da situação e são adotadas pelos participantes na relação de troca. Elas acabam servindo como um guia no processo de troca.

Apesar de existirem diferentes visões sobre as trocas sociais, os teóricos concordam que elas envolvem uma série de interações que tendem a gerar o sentimento de obrigação. A Teoria da troca Social advoga que essas interações são comumente vistas como interdependentes, ou seja, que dependem da ação de outras pessoas (BLAU, 1964). Essa teoria enfatiza ainda que essas transações de interdependência têm um potencial para gerar relações de alta qualidade, embora possam ocorrer apenas em certas circunstâncias. As trocas sociais compreendem ações dependentes das reações gratificantes dos outros, que, ao longo do tempo, proporcionam transações e relacionamentos mutuamente gratificantes (CROPANZANO; MITCHELL, 2005).

O comportamento nas organizações, segundo a Teoria da Troca Social, estrutura-se por meio de regras e normas de trocas. Contudo as pesquisas de gestão focam a expectativa de reciprocidade. Isso porque a reciprocidade e a retribuição são, provavelmente, a regra de troca mais comum e conhecida. Goulder (1960), no intuito de esclarecer e reduzir as possíveis ambiguidades na definição de reciprocidade, distingue três tipos de reciprocidade que ajudam a esclarecer sua natureza: 1) a reciprocidade como uma troca interdependente considera que o resultado é baseado na combinação dos esforços entre as partes, que envolvem arranjos complementares e mútuos. Nesse sentido, a interdependência é considerada uma característica da troca social. Uma troca recíproca não inclui uma barganha explícita. Essa característica da troca reduz seu risco e encoraja a cooperação, gerando ciclos que se autorreforçam. Caso contrário, não implicaria uma troca social, de modo que, se uma pessoa oferece um benefício, a parte beneficiada deveria responder de forma similar; 2) a reciprocidade como uma crença popular trata da expectativa cultural de que as pessoas alcançam aquilo que merecem. Esse aspecto da reciprocidade lida com a crença de que as trocas alcançaram um equilíbrio justo e aqueles que são colaborativos receberam ajuda no futuro; 3) A reciprocidade como uma norma ou orientação individual pode ser considerada um princípio universal ou uma visão compartilhada de que aqueles que não retribuírem serão punidos. Nesse caso, a norma descreve um comportamento esperado, como as 
pessoas deveriam se comportar, diferentemente da crença. Apesar de a natureza da reciprocidade indicar princípios que parecem universais, é importante ressaltar que nem todos os indivíduos estarão dispostos a agir de forma recíproca e também que diferentes pessoas o farão em graus distintos.

Apesar do foco maior na reciprocidade, a Teoria da Troca Social aborda uma variedade de regras de troca que, segundo Meeker (1971), podem ser classificadas em seis tipos: reciprocidade, racionalidade, altruísmo, ganho do grupo, consistência do status e competição. As regras de altruísmo e ganho do grupo são exemplos de regras que levam em consideração, respectivamente, o benefício do outro, mesmo que isso possa gerar custos pessoais e o benefício do grupo, independentemente dos seus interesses particulares (CROPANZANO; MITCHELL, 2005). Segundo Farrel e Petterson (1982), as relações de troca são relevantes para os estudos do comportamento político, uma vez que este lida com a distribuição de recursos.

As pesquisas contemporâneas de gestão que tratam da Teoria da Troca Social e que ganharam mais atenção dos estudiosos foram as que abordaram as relações no trabalho. Esse modelo da Teoria da Troca Social estipula que certos antecedentes levam a conexões interpessoais referidas como relações de trocas sociais. Essas relações acontecem quando empregados "cuidam" de outros empregados, o que gera consequências benéficas. As trocas sociais, quando vantajosas e justas, podem gerar um comportamento efetivo no trabalho e atitudes positivas dos empregados (CROPANZANO; MITCHELL, 2005). Essa visão é convergente com a ideia de que líderes participam de atividades políticas para beneficiar seus subordinados (HOCHWARTER, 2012). Fornecer um benefício aos outros cria um sentimento de dívida que pode trazer resultados positivos para as partes envolvidas (ELLEN et al., 2013).

As pesquisas sobre gestão examinaram extensivamente as formas de trocas inter-relacionais com especial interesse pelos diferentes grupos envolvidos nas trocas, como superiores imediatos, pares, funcionários, clientes, fornecedores. Essas relações distintas têm implicações nos comportamentos. Especialmente, em razão de os indivíduos tenderem a retribuir os benefícios que eles receberam e que representam a boa vontade e ajuda aos grupos nos quais eles possuem relações de troca social (CROPANZANO; MITCHELL, 2005).

As trocas acontecem além das questões materiais. Os seis tipos de recursos que são trocados, segundo Foa e Foa (1974) são: amor, status, informação, dinheiro, objetos 
e serviços. Uma dimensão importante dos recursos é a sua natureza particular ou universal. Os resultados dos recursos podem ser de dois tipos, econômicos e socioemocionais. Os resultados socioemocionais são aqueles relacionados às necessidades sociais e de estima que são frequentemente simbólicos e particulares. Os recursos particulares são mais susceptíveis a relações próximas.

Uma contribuição importante para a Teoria da Troca Social foi a comparação entre as trocas econômicas e as trocas sociais feita por Blau (1964). Esse autor argumenta que somente as trocas sociais envolvem favores que criam uma obrigação difusa no futuro e que a natureza do retorno não pode ser barganhada. Para ele, somente as trocas sociais geram o sentimento pessoal de obrigação, gratidão, confiança, enquanto as trocas puramente econômicas não. Os benefícios que envolvem as trocas sociais não têm um preço específico em termos de um único meio quantitativo de troca, na verdade, essas trocas tendem a criar padrões sociais duradouros. As trocas sociais envolvem confiança nas outras pessoas e obrigações pessoais. As características da relação entre parceiros de troca afetam o processo de troca social. $\mathrm{O}$ sucesso da troca pode levar o indivíduo a se comprometer com o outro. As trocas sociais compreendem as reações gratificantes das ações dos outros, o que, no longo prazo, gera transações e relações mútuas e recompensadoras.

Essa teoria contribui para o entendimento do aspecto positivo da competência política, uma vez que ela demonstra que alguns comportamentos na organização podem ser classificados como trocas sociais e que essas ações podem ser realizadas visando ao benefício de outras pessoas, não necessariamente com o objetivo de alcançar resultados materiais ou apenas para o benefício próprio. Pelo contrário, as relações de trocas sociais, muitas vezes, são ações realizadas em busca de uma reciprocidade não explícita e sim simbólica, como: reputação, aceitação social e legitimidade. Essa busca por reciprocidade pode ser baseada em crença popular, no princípio universal da norma de conduta, na consciência de que somos serem interdependentes e que, portanto, "uma mão lava a outra", ou mesmo em todas essas razões em conjunto. 


\subsubsection{Teoria Socioanalítica}

A Teoria Socioanalítica tem suas raízes na Psicologia Interpessoal e é projetada para explicar as diferenças individuais em relação ao sucesso na carreira. É baseada em duas generalizações relevantes ao comportamento nas organizações. As pessoas sempre vivem e trabalham em grupos, e grupos são sempre estruturados em termos de hierarquias de status. Essas generalizações sugerem a presença de dois padrões de comportamento, que são: dar-se bem com outros membros do grupo e avançar na carreira e alcançar status. Os dois motivos básicos que permeiam as interações sociais são: 1) motivação pelo ganho de status, poder e controle de recursos e pelo medo da perda de status e controle; 2) motivação pela busca de aceitação e apoio e pelo medo do isolamento social. Conseguir progredir e se desenvolver na carreira, assim como relacionar-se bem, são temas universais nas questões humanas. E, de maneira geral, satisfazer essas necessidades aumenta o sentimento de adequação do indivíduo e seu bem-estar.

Ao se apresentar para o outro no jogo social, os participantes tentam controlar o modo como ele é visto pelo outro. Aqueles que são competentes no jogo conseguirão convencer os outros da imagem que desejam passar. Hogan e Shelton (1998) sugerem que a diferença individual de habilidade de transmitir seus motivos por meio de um comportamento social efetivo depende da competência social. Para serem bemsucedidas, as pessoas usam suas competências sociais a fim de alavancar suas motivações durante as interações sociais.

A Teoria Socioanalítica especifica que a personalidade deveria ser definida da perspectiva do ator e do observador. A personalidade, na visão do ator, é a identidade da pessoa que é formada pelas estratégias que ela utiliza para perseguir aceitação e status. A identidade controla o comportamento social de um ator. Já a personalidade, na visão do observador, é a reputação de uma pessoa. E a reputação é definida em termos da avaliação de traços como: conformado, colaborativo, falante, competitivo, calmo, curioso etc. A reputação reflete a visão do observador sobre as características do comportamento em público do ator. Ela é o vínculo entre o esforço do ator de atingir aceitação e status e a avaliação desses esforços pelos observadores. A reputação descreve o comportamento da pessoa e a identidade explica esse comportamento (HOGAN; HOLLAND, 2003). 
Segundo Goldberg (1981), após a avaliação de 75 anos de pesquisas em fatores analíticos da personalidade, encontraram-se os cinco maiores fatores da personalidade que representam a estrutura do observador. Esses fatores representam a taxonomia da reputação. Fator 1: extroversão e emergência; Fator 2: complacência; Fator 3: conscienciosidade; Fator 4: estabilidade emocional, Fator 5: abertura intelectual para a experiência. A reputação é um índice aproximado da aceitação e do status que uma pessoa possui e está codificada nos cinco maiores fatores da personalidade. Assim, é possível concluir que esses cinco fatores também representam o grau de aceitação e status de uma pessoa (HOGAN; HOLLAND, 2003).

Essa teoria está relacionada ao presente estudo, uma vez que Ferris et al. (2007), em seu modelo metateórico, utilizou os quatro primeiros dos cinco grandes fatores da personalidade para explicar os dispositivos e habilidades pessoais que antecedem a competência política. E também pelo papel que a reputação tem no vínculo entre o esforço do ator e a avaliação desse esforço pelo observador, já que se está considerando neste estudo a reputação como um possível resultado da competência política das lideranças. 


\section{METODOLOGIA}

Nesta seção, apresenta-se a metodologia utilizada na presente pesquisa detalhando questões como o paradigma científico, a abordagem da investigação, a forma de coleta e da análise dos dados. Essas especificações são importantes para demonstrar os critérios, o processo e o contexto em que se deu a pesquisa.

\subsection{Paradigma científico}

Guba e Lincoln (1994) alertam para a importância dos paradigmas científicos na condução de pesquisas científicas. Quatro paradigmas norteiam a condução de pesquisas científicas: positivismo, pós-positivismo, teoria crítica e construtivismo. Tais paradigmas são sustentados por três pilares: 1) ontológico, que diz respeito à natureza e à forma da realidade e ao que se pode conhecer dela; 2) epistemológico, que se refere à natureza do relacionamento entre o observador e aquilo que pode ser observado; 3 ) metodológico, que se relaciona a como o pesquisador busca conhecer aquilo que ele acredita poder conhecer, ou seja, o método mais apropriado à investigação daquilo que ele busca estudar. O presente estudo é desenvolvido a partir do paradigma póspositivista e, por este motivo, (1) assume que a realidade é real e pode ser compreendida, mas de maneira imperfeita e sujeita a críticas e correções; (2) acredita que pode haver uma separação entre observador e objeto, mas reconhece que as influências podem ocorrer e que os resultados são provavelmente verdadeiros, no entanto estão sujeitos a falhas; e (3) considera que, na perspectiva desses autores tanto o método qualitativo quanto o quantitativo podem ser utilizados de maneira apropriada em qualquer dos quatro paradigmas de pesquisa. As questões do paradigma representam o sistema de crenças básicas que guiam o pesquisador (GUBA; LINCOLN, 1994). Nesta pesquisa, utilizaram se métodos mistos, que incluem métodos quantitativos e qualitativos, porém deu-se maior ênfase à utilização de técnicas qualitativas.

O pós-positivismo representa o pensamento posterior ao positivismo, desafia a noção tradicional de verdade absoluta do conhecimento e reconhece que não se pode ser "positivo" sobre as declarações de conhecimento quando se estuda o comportamento humano e as ações do ser humano. Os pós-positivistas defendem uma filosofia determinística, na qual as causas provavelmente determinam os efeitos ou resultados. São reducionistas, na medida em que tentam reduzir as ideias a um conjunto pequeno e 
distinto a ser testado para a compreensão da questão de pesquisa. As suposições fundamentais dessa posição são que: 1) o conhecimento é conjectural - a verdade absoluta nunca poder ser encontrada; 2) a pesquisa é um processo de fazer declarações e depois refiná-las ou abandoná-las; 3) os dados, as evidências e as considerações racionais moldam o conhecimento; 4) a pesquisa procura desenvolver declarações relevantes para explicar a situação de interesse ou que descrevam as relações causais de interesse; 5) a objetividade deve ser buscada - examinar os métodos e as conclusões para evitar vieses (CRESWELL, 2010).

\subsection{Abordagem de investigação}

$\mathrm{Na}$ presente pesquisa, utilizaram-se os métodos quantitativos e qualitativos. Esses métodos não constituem unicamente maneiras diferentes de fazer a mesma coisa. Cada método possui uma lógica diferente, assim como forças e fraquezas distintas, e sua adequação pode variar em razão do propósito da pesquisa (MAXWELL, 1996). Esta pesquisa utilizou métodos mistos que, segundo Creswell e Clark (2007), constituem uma abordagem da investigação que combina ou associa as formas qualitativa e quantitativa. A mistura das duas abordagens em um estudo é mais do que uma simples coleta e análise dos dois tipos de dados, envolve o seu uso em conjunto, de modo que a força geral do estudo seja maior do que a da pesquisa qualitativa ou quantitativa isoladamente (CRESWELL, 2010). A avaliação qualitativa caracteriza-se pela descrição, compreensão e interpretação de fatos e fenômenos. Em contrapartida, na avaliação quantitativa predominam as mensurações. $\mathrm{O}$ procedimento utilizado foi o de métodos mistos sequenciais, que são aqueles em que o pesquisador procura elaborar ou expandir os achados de um método com os de outro método. O estudo pode se iniciar com um método quantitativo, pelo qual uma teoria ou conceito são testados, seguindo por um método qualitativo, que envolva uma exploração detalhada de alguns casos ou indivíduos (CRESWELL, 2010).

A escolha de métodos mistos se deu pela sua aderência aos objetivos desta pesquisa. Primeiramente, foi feita uma revisão bibliográfica sobre a perspectiva política da liderança, especialmente sobre o construto "competência política". Optou-se por seguir os trabalhos desenvolvidos pelo grupo de estudos de Ferris, que, desde o final da década de 1990, realiza vários estudos empíricos e incrementou os estudos de política no nível micro, ao examinar a percepção da política nas organizações em relação aos 
seus antecedentes, fatores de moderação e resultados da percepção de outros em relação ao ambiente político (FERRIS et al., 1989; FERRIS et al., 2005; FERRIS et al., 2007). Esses autores desenvolveram uma escala para mensurar a competência política nas suas quatro dimensões críticas (astúcia social, influência interpessoal, habilidade de networking e sinceridade evidente). Com o intuito de aproveitar o conhecimento acumulado por essas pesquisas, optou-se por realizar a validação para o português da escala existente para medir a competência política e aplicá-la no contexto nacional. Segundo Ferris e Treadway (2012), estabelecer uma teoria forte necessariamente requer o aumento do rigor e sua expansão. É sugerido que pesquisadores deixem as pesquisas de pacote único para focar a replicação construtiva a fim de criar avanços na teoria. Por essa razão, neste estudo validou-se para o português a escala existente e replicou-se a aplicação da escala no contexto nacional.

Definiu-se, para esta pesquisa, que apenas aplicar um questionário fechado sobre esse construto não seria suficiente para captar de forma ampla o significado que essa competência tem para as organizações e para os profissionais brasileiros. Principalmente, em razão da inexistência de estudos anteriores sobre a competência política da liderança no Brasil e pela natureza sensível do tema. A pesquisa foi realizada em duas etapas, sendo que a primeira foi a fase quantitativa do estudo, em que se procedeu à validação do questionário em português, o que será detalhado em seguida no item Ferramenta. Na segunda etapa, foram realizadas entrevistas com dois grupos de profissionais (estudo de casos com gestores e um grupo de executivos experientes que ocupam ou ocuparam altos cargos em organizações) que responderam às questões abertas (qualitativas) sobre o tema, juntamente com o questionário validado sobre competência política e algumas questões sobre reputação e legitimidade.

A metodologia adotada nos estudos sobre a política nas organizações é particularmente complexa, em razão de definição, estruturação, mensuração e nível de análise que têm sido aplicados de maneira inconsistente (FERRIS et al., 2002; DIPBOYE; FOSTER, 2002). A política nas organizações engloba uma grande variedade de processos psicológicos e comportamentos. Além disso, são inerentes à maioria das definições da política nas organizações aspectos como a motivação das pessoas para se engajarem em um comportamento que seja visto como político. Não se trata de apenas observar um comportamento para determinar se uma pessoa está agindo de certo modo ou não. Em alguns casos, a manifestação de um mesmo comportamento pode ter sido causada por diferentes motivos. Além disso, o comportamento político 
pode ocorrer em qualquer nível da organização (empregado, superior, grupo, organização) e qualquer um dos níveis pode exercer influência nos demais níveis. Todas essas questões contribuem para a natureza complexa dos estudos da política nas organizações e, ao mesmo tempo, indicam boas oportunidades para futuras pesquisas (MCFARLAND; VAN IDDEKINGE; PLOYHART, 2012).

A abordagem qualitativa do estudo foi adotada em razão da coerência que existe entre ela e os objetivos desta tese. $O$ estudo qualitativo permite a compreensão da complexidade das interações sociais expressas na vida cotidiana e do significado que as pessoas atribuem a elas. Essa abordagem é fundamentada nas experiências vividas pelas pessoas. Este estudo tem, ainda, caráter exploratório, na medida em que seu propósito é compreender e descrever a perspectiva política da liderança, principalmente como as lideranças se classificam e são percebidas em relação à competência política e se os aspectos positivos do comportamento político são identificados no ambiente organizacional brasileiro (MARSHAL; ROSSMAN, 1999; CRESWELL, 2010).

A estratégia de pesquisa de estudo de caso pede avaliação qualitativa, uma vez que objetiva o estudo de uma unidade social que se analisa profunda e intensamente. $\mathrm{O}$ estudo de caso é uma investigação empírica que pesquisa fenômenos dentro de seu contexto real (pesquisa naturalística), em que não há controle por parte do pesquisador dos eventos e variáveis e cujo objetivo é apreender a totalidade de uma situação e, criativamente, descrever, compreender e interpretar a complexidade de um caso concreto. $\mathrm{O}$ estudo de caso, na presente pesquisa, teve como objetivo avaliar o contexto da organização, mas, principalmente, permitir que profissionais que se conhecem e se relacionam avaliassem a competência política dos seus pares ou subordinados. Essa estratégia de pesquisa possibilita a penetração na realidade social, não conseguida plenamente pela avaliação quantitativa. No campo das ciências sociais aplicadas, há fenômenos de elevada complexidade e de difícil quantificação; nesses casos, as abordagens qualitativas são adequadas, tanto em relação ao tratamento contextual do fenômeno, quanto no que se refere à sua operacionalização. Os eventos complexos pressupõem um tratamento em maior nível de detalhamento das relações dentro das empresas entre indivíduos e as organizações, bem como dos relacionamentos que estabelecem com o meio ambiente em que estão inseridos (MARTINS; THEÓPHILO, 2007). 


\subsection{Coleta de dados}

A fim de apresentar a forma como os dados foram coletados serão comentadas as ferramentas utilizadas e as definições sobre a amostra pesquisada e o perfil da amostra.

\subsubsection{Ferramenta}

A primeira etapa deste estudo foi a validação da escala Political Skill Inventory (PSI) (FERRIS et al., 2005) para o português. Nessa etapa quantitativa da pesquisa, optou-se por aplicar o questionário criado por Ferris et al. (2005) no contexto nacional. Após uma tradução realizada pela autora desta tese, foram realizadas as seguintes validações: tradução reversa, validação de conteúdo e análise fatorial confirmatória.

A tradução reversa foi realizada por um brasileiro que estava vivendo há mais de dez anos nos Estados Unidos e acabara de retornar ao Brasil. Ele recebeu as questões em português e as traduziu para o inglês. A escala traduzida por ele foi comparada com a original em inglês e não foram encontradas diferenças.

A validação de conteúdo (ou de expressão) é a avaliação do grau de correspondência entre os itens selecionados para construir uma escala múltipla e sua definição conceitual. Avalia subjetivamente a correspondência entre os itens individuais e o conceito por meio do julgamento de especialistas, pré-testes com múltiplas subpopulações ou outros meios. O objetivo é garantir que os itens da escala não sejam todos empíricos, mas incluam considerações práticas e teóricas (HAIR JR. et al., 2005). Essa validação foi realizada com os especialistas do grupo de estudos sobre liderança da FEA-USP, sendo que oito pessoas participaram dela. Elas receberam a escala em português e a definição das quatro dimensões. Para cada questão, deveriam apontar em qual fator o item ficaria mais bem classificado. Foram considerados adequados os itens classificados no fator esperado em pelo menos seis respostas. Em uma primeira rodada, quatro itens não apresentaram a classificação correta. Eles foram reescritos, bem como os fatores foram mais bem explicados. Em uma segunda rodada, dois itens apresentaram problemas e foram reescritos. Essa nova descrição também atendeu à descrição reversa. $\mathrm{Na}$ terceira rodada, todos os 18 itens ficaram adequadamente classificados.

Após a validação de conteúdo, foi criado um questionário em dois formatos digital e impresso - para ser aplicado via web e presencialmente. A aplicação do 
instrumento foi empreendida por meio de questionários virtuais do Google-Forms, que foram divulgados por meio das mídias eletrônicas Facebook, WhatsApp, e-mails de contatos pessoais e e por meio de lista de e-mails interna enviada pela coordenação da FEA-USP aos seus alunos de pós-graduação para alunos da FEA-USP. O instrumento de pesquisa foi coletado também, por meio de formulários impressos, aplicados a estudantes de graduação de faculdades de São Paulo. Após a coleta dos dados, foram realizadas as seguintes validações: tradução reversa, validação de conteúdo e análise fatorial confirmatória.

O questionário com questões sociodemográficas e a escala traduzida com 18 itens da Escala das Competências Políticas foi respondido por 208 pessoas, mas oito respostas foram descartadas por conter missings (itens sem resposta) ou mesma resposta em todos os itens.

A amostra de 200 respondentes foi composta por 110 mulheres $(55 \%)$ e 90 homens (45\%), com idades entre 18 e 60 anos, com média de 34,2 anos e desvio padrão de 10,2 anos. Dos respondentes, 119 não eram líderes (59,5\%); dos 81 líderes, 63 (77,8\%) tinham autonomia para negociar a definição orçamentária para sua área, 20 (24,7\%) eram líderes de outros líderes, e a média de tempo de liderança era de 8,3 anos. Também 153 (76,5\%) trabalhavam em empresas privadas de diversos setores da Economia e 137 (68,5\%) eram da cidade de São Paulo.

Essa amostra foi submetida à análise fatorial confirmatória, no software SmartPLS 3.0, apresentando testes de validade convergente e discriminante.

A validade convergente avalia o grau em que duas medidas do mesmo conceito estão correlacionadas. O teste empírico pode incluir a análise de correlação entre as medidas alternativas de um conceito e a escala múltipla, esperando-se altos valores de correlação (HAIR JR. et al., 2005). Para este estudo, a validade convergente foi avaliada pelos valores da variância média extraída (Average Variance Extracted - AVE) dos fatores igual ou superior a 0,5 , pois estes que representam a alta correlação com seus itens ou variáveis (ZWICKER et al., 2008), pelo índice de confiabilidade (alfa de Cronbach) superior a 0,6 e pelo valor de confiabilidade composta superior a 0,7. Confiabilidade é a extensão em que uma variável ou conjunto de variáveis é consistente com o que se pretende medir, ou seja, se medidas repetidas forem executadas, as medidas confiáveis serão consistentes em seus valores (HAIR JR. et al., 2005).

A validade discriminante consiste no grau em que dois conceitos similares são distintos. Nesse caso, o teste empírico também avalia a correlação entre medidas, porém 
a escala múltipla está correlacionada com uma medida semelhante, mas conceitualmente distinta, esperando-se valores de correlação baixos (HAIR JR. et al., 2005). Segundo Zwicker, Souza e Bido (2008), há validade discriminante quando o valor da raiz quadrada da Average Variance Extracted (AVE) de um construto (ou variável latente) é maior que as correlações entre os construtos ou quando as cargas cruzadas entre os construtos são menores que suas respectivas variáveis componentes, o que é chamado de critério de Fornell-Larcker (1981).

$\mathrm{Na}$ análise de convergência, foram retirados os itens 1 (HN1) e 18 (AS5), devido à baixa carga fatorial no fator esperado e cargas cruzadas com outros fatores.

O item 1 - I spend a lot of time and effort at work networking with others - foi traduzido como "Gasto muito tempo e esforço no trabalho me relacionando com outras pessoas". A alta carga cruzada no fator "Habilidade de criar redes de relacionamento" pode ser devido à compreensão de que o fato de se relacionar com outras pessoas no trabalho não necessariamente implica criar redes de relacionamento. O item 18 - I pay close attention to people's facial expressions - foi traduzido como "Presto bastante atenção nas expressões faciais das pessoas”. Esse item apresentou baixa carga fatorial em todos os fatores. A seguir, as perguntas do questionário de competência:

\section{Questionário - Competências Políticas Validado em Português - Versão Gestores}

1. Gasto muito tempo e esforço no trabalho me relacionando com outras pessoas.

\section{(Excluída)}

2. Sou capaz de fazer com que as pessoas sintam-se confortáveis e à vontade ao meu lado.

3. Sou capaz de me comunicar com os outros de forma fácil e efetiva.

4. É fácil para mim desenvolver um bom relacionamento com a maioria das pessoas.

5. Eu entendo muito bem as pessoas.

6. Tenho facilidade em construir relacionamentos com pessoas influentes no trabalho.

7. Eu sou particularmente hábil em perceber as motivações e as agendas ocultas de outros.

8. Ao me comunicar com as pessoas, tento ser verdadeiro no que digo e faço.

9. Eu desenvolvi uma grande rede de colegas e associados no trabalho com que posso contar quando eu preciso que as coisas aconteçam. 
10. No trabalho, eu conheço e tenho bom relacionamento com várias pessoas importantes.

11. Eu passo muito tempo no trabalho desenvolvendo conexões com os outros.

12. Eu sou bom em fazer as pessoas gostarem de mim.

13. É importante que as pessoas acreditem que eu sou sincero no que digo e faço.

14. Eu tento mostrar um interesse verdadeiro pelas pessoas.

15. Eu sei utilizar bem meus relacionamentos para fazer as coisas acontecerem no trabalho.

16. Eu tenho boa intuição e sou habilidoso em me apresentar aos outros.

17. Intuitivamente, eu pareço saber as coisas certas a dizer ou fazer para influenciar os outros.

18. Eu presto bastante atenção nas expressões faciais das pessoas. (Excluída)

Com os 16 itens restantes, a análise de convergência apresentou Alfa de Cronbach superior a 0,6 em todos os fatores, confiabilidade composta bem superior a 0,7 em todos os fatores e variância média extraída de cada fator acima de 0,5 (TAB. 1).

Tabela 1 - Análise de convergência

\begin{tabular}{lccc}
\hline & $\begin{array}{c}\text { Alfa de } \\
\text { Cronbach }\end{array}$ & $\begin{array}{c}\text { Confiabilidade } \\
\text { composta }\end{array}$ & $\begin{array}{c}\text { Variância } \\
\text { Média } \\
\text { Extraída } \\
\text { (AVE) }\end{array}$ \\
\hline Astucia Social & 0,737 & 0,835 & 0,561 \\
Habilidade de Networking & 0,824 & 0,878 & 0,591 \\
Influencia Interpessoal & 0,768 & 0,852 & 0,590 \\
Sinceridade Evidente & 0,673 & 0,819 & 0,602 \\
\hline
\end{tabular}

Fonte: Dados da pesquisa.

A análise de discriminância foi feita primeiramente pela análise das cargas cruzadas, sendo que cada item deve ter alta carga (preferencialmente maior que 0,7 ) no fator correspondente e baixa carga nos demais fatores (TAB. 2). 
Tabela 2 - Cargas cruzadas

\begin{tabular}{lcccc}
\hline & $\begin{array}{c}\text { Astúcia } \\
\text { Social }\end{array}$ & $\begin{array}{c}\text { Habilidade } \\
\text { de } \\
\text { Networking }\end{array}$ & $\begin{array}{c}\text { Influência } \\
\text { Interpessoal }\end{array}$ & $\begin{array}{c}\text { Sinceridade } \\
\text { Evidente }\end{array}$ \\
\hline AS1 & 0,642 & 0,351 & 0,471 & 0,238 \\
AS2 & 0,751 & 0,489 & 0,356 & 0,125 \\
AS3 & 0,765 & 0,560 & 0,472 & 0,215 \\
AS4 & 0,825 & 0,595 & 0,478 & 0,212 \\
HN2 & 0,581 & 0,797 & 0,490 & 0,241 \\
HN3 & 0,421 & 0,694 & 0,448 & 0,426 \\
HN4 & 0,533 & 0,857 & 0,464 & 0,309 \\
HN5 & 0,456 & 0,700 & 0,349 & 0,345 \\
HN6 & 0,589 & 0,783 & 0,452 & 0,307 \\
II1 & 0,474 & 0,427 & 0,809 & 0,380 \\
II2 & 0,500 & 0,487 & 0,770 & 0,330 \\
II3 & 0,364 & 0,403 & 0,755 & 0,368 \\
II4 & 0,479 & 0,450 & 0,737 & 0,351 \\
SE1 & 0,156 & 0,233 & 0,288 & 0,696 \\
SE2 & 0,178 & 0,331 & 0,424 & 0,812 \\
SE3 & 0,274 & 0,395 & 0,355 & 0,814 \\
\hline
\end{tabular}

Fonte: Dados da pesquisa.

Posteriormente, foi avaliada a discriminância pelo critério de Fornell-Larcker (1981), sendo que todas as raízes quadradas de AVE de cada fator ficaram maiores que as cargas cruzadas com os demais fatores (TAB. 3).

Tabela 3 - Critério de Fornell-Larcker

\begin{tabular}{lcccc}
\hline & $\begin{array}{c}\text { Astúcia } \\
\text { Social }\end{array}$ & $\begin{array}{c}\text { Habilidade } \\
\text { de } \\
\text { Networking }\end{array}$ & $\begin{array}{c}\text { Influência } \\
\text { Interpessoal }\end{array}$ & $\begin{array}{c}\text { Sincerida-de } \\
\text { Evidente }\end{array}$ \\
\hline $\begin{array}{l}\text { Astúcia Social } \\
\text { Habilidade de }\end{array}$ & $\mathbf{0 , 7 4 9}$ & & & \\
Networking & 0,675 & $\mathbf{0 , 7 6 9}$ & & \\
Influência Interpessoal & 0,596 & 0,577 & $\mathbf{0 , 7 6 8}$ & \\
Sinceridade Evidente & 0,265 & 0,421 & 0,465 & $\mathbf{0 , 7 7 6}$ \\
\hline
\end{tabular}

Fonte: Dados da pesquisa.

O instrumento validado com 16 itens e quatro fatores é apresentado no QUADRO 1: 
Quadro 1 - Fatores e itens da Escala de Competências Políticas validada no Brasil

\begin{tabular}{|c|c|c|}
\hline Fator & Item & $\begin{array}{l}\text { Carga } \\
\text { fatorial }\end{array}$ \\
\hline \multirow{4}{*}{$\begin{array}{l}\text { Influência interpessoal } \\
\text { Habilidade relacionada às } \\
\text { características pessoais, capacidade de } \\
\text { conseguir atrair as pessoas, estilo de } \\
\text { comunicação efetivo. } \\
(\alpha=0,768)\end{array}$} & $\begin{array}{l}\text { Sou capaz de fazer com que as pessoas sintam-se } \\
\text { confortáveis e a vontade ao meu lado. }\end{array}$ & 0,809 \\
\hline & $\begin{array}{l}\text { Sou capaz de me comunicar com os outros de maneira } \\
\text { fácil e efetiva. }\end{array}$ & 0,770 \\
\hline & $\begin{array}{l}\text { Tenho facilidade em desenvolver um bom } \\
\text { relacionamento com a maioria das pessoas. }\end{array}$ & 0,755 \\
\hline & Sou bom (boa) em fazer as pessoas gostarem de mim. & 0,737 \\
\hline \multirow{4}{*}{$\begin{array}{l}\text { Astúcia social } \\
\text { Habilidade para entender o outro e as } \\
\text { relações sociais. Saber como se } \\
\text { comportar nas interações sociais. } \\
(\alpha=0,737)\end{array}$} & Eu entendo muito bem as pessoas. & 0,642 \\
\hline & $\begin{array}{l}\text { Sou particularmente hábil em perceber as motivações e } \\
\text { as agendas ocultas de outros. }\end{array}$ & 0,751 \\
\hline & $\begin{array}{l}\text { Tenho boa intuição e sou habilidoso(a) em me } \\
\text { apresentar aos outros. }\end{array}$ & 0,765 \\
\hline & $\begin{array}{l}\text { Instintivamente eu entendo os outros, sabendo o que } \\
\text { fazer ou dizer para influenciá-los. }\end{array}$ & 0,825 \\
\hline \multirow{5}{*}{$\begin{array}{l}\text { Habilidade de criar redes de } \\
\text { relacionamento } \\
\text { Motivação e habilidade para gastar } \\
\text { tempo e esforço em desenvolver } \\
\text { relações sociais no trabalho. } \\
(\alpha=0,824)\end{array}$} & $\begin{array}{l}\text { Criar relacionamento com pessoas influentes no } \\
\text { trabalho é uma tarefa fácil para mim. }\end{array}$ & 0,797 \\
\hline & $\begin{array}{l}\text { Desenvolvi uma grande rede de colegas e associados } \\
\text { no trabalho que posso contar quando eu preciso que as } \\
\text { coisas aconteçam. }\end{array}$ & 0,694 \\
\hline & $\begin{array}{l}\text { No trabalho, eu conheço e tenho bom relacionamento } \\
\text { com várias pessoas importantes. }\end{array}$ & 0,857 \\
\hline & $\begin{array}{l}\text { Passo muito tempo no trabalho desenvolvendo } \\
\text { conexões com os outros. }\end{array}$ & 0,700 \\
\hline & $\begin{array}{l}\text { Sei utilizar bem meus relacionamentos para fazer as } \\
\text { coisas acontecerem no trabalho. }\end{array}$ & 0,783 \\
\hline \multirow{3}{*}{$\begin{array}{l}\text { Sinceridade evidente } \\
\text { Aparentar sinceridade, genuinidade, } \\
\text { integridade, autenticidade. Apresentam } \\
\text { interesse nas outras pessoas. São vistos } \\
\text { pelos outros exatamente como são. } \\
(\alpha=0,673)\end{array}$} & $\begin{array}{l}\text { Ao me comunicar com as pessoas tento ser } \\
\text { verdadeiro(a) no que digo e faço. }\end{array}$ & 0,696 \\
\hline & $\begin{array}{l}\text { É importante que as pessoas acreditem que eu sou } \\
\text { sincero(a) no que digo e faço. }\end{array}$ & 0,812 \\
\hline & Tento mostrar um interesse verdadeiro nas pessoas. & 0,814 \\
\hline
\end{tabular}

Fonte: Dados da pesquisa.

$\mathrm{Na}$ segunda etapa deste estudo, a coleta dos dados foi realizada por meio de entrevistas semiestruturadas, que tiveram duração de 35 a 90 minutos. As entrevistas constituem uma ferramenta apropriada para investigar atitudes, intenções e motivações envolvendo interpretações e ambiguidades. As entrevistas, segundo Kahn e Cannell (1957) apud Marshall e Rossman (1999), podem ser compreendidas como uma conversa com um propósito. Como principal vantagem, as entrevistas permitem o levantamento de questões relevantes e profundas (DENZIN; LINCOLN, 1994) e de grande quantidade de dados de maneira rápida (MARSHAL; ROSSMAN, 1999). No caso da entrevista semiestruturada, procurou-se captar a percepção dos entrevistados a respeito do ambiente político das organizações, da função política do gestor, da caracterização da competência política e sua classificação em relação a essa competência e os seus impactos na carreira. As entrevistas realizadas não tiveram nenhuma categorização a priori que pudesse limitar a compreensão do fenômeno estudado. As questões foram 
elaboradas em torno dos principais temas e objetivos apresentados anteriormente neste estudo.

O roteiro da entrevista, apresentado a seguir, consistiu em perguntas abertas relacionadas à percepção dos profissionais a respeito do tema. Propositalmente, as questões relacionadas aos aspectos positivos do comportamento político foram abordadas primeiramente, em razão de a conotação negativa ser a dominante, podendo prejudicar uma visão positiva. As questões foram desenvolvidas tendo como suporte o referencial teórico e os objetivos do estudo. Todas as entrevistas foram gravadas, transcritas e enviadas para aprovação dos respondentes. A ideia de pedir a aprovação da transcrição pelos respondentes foi uma tentativa de garantir a veracidade e o ponto de vista do respondente, assim como oferecer uma segurança para o entrevistado de que nenhuma informação indesejada seria divulgada, tendo em vista a natureza sensível do tema.

\section{Roteiro de Entrevista - Perguntas Abertas (Qualitativas)}

1. Ao assumir cargos mais altos na organização, o profissional passa a lidar mais intensamente com os conflitos de interesse, disputas por espaço, recursos, reconhecimento e negociações. O que o Sr.(a) pensa sobre esse aspecto da função do gestor?

2. Como o Sr. (a) descreveria o ambiente político da organização?

3. Descreva as características de um profissional competente politicamente.

4. Na seleção ou promoção de profissionais para sua equipe, além dos aspectos técnicos, as questões dos relacionamentos sociais e sabedoria política eram levados em consideração? Por quê?

5. Identifique uma situação em que o $\operatorname{Sr}(a)$ precisou da competência política para atuar em uma negociação ou lidar com um conflito ou uma disputa. Qual era a situação? O que antecedeu o problema? Como foi o processo de resolução do problema? Qual foi o resultado?

6. O Sr(a) recebeu algum treinamento ou foi exposto a situações que the permitissem o desenvolvimento de competências políticas, antes de assumir seu cargo?

7. O Sr.(a) se classificaria como um profissional competente politicamente? Se sim, isso ajudou? Se não, fez falta? Por quê?

8. Em um momento de conflito muito acirrado, como o problema é resolvido na empresa? 
9. O comportamento político pode ser percebido de diferentes maneiras em razão da intenção e dos resultados das ações dos seus atores. Exemplifique como e quando alguns profissionais podem utilizar esse comportamento de maneira funcional ou disfuncional.

10. Em sua opinião, qual a melhor forma de incentivar o comportamento político funcional? E qual a melhor maneira de inibir o comportamento político disfuncional?

11. O que gera uma boa reputação para uma liderança?

12. Para o $\operatorname{Sr}(a)$, o que significa um líder legítimo?

Ao mesmo tempo, foi aplicado o questionário validado neste estudo para medir a competência política dos gestores, a reputação e a atribuição de legitimidade, com respostas do tipo escala Likert de 7 pontos entre discordo totalmente e concordo totalmente. A decisão de coletar os dados qualitativos e quantitativos concomitantemente teve a intenção de possibilitar uma comparação entre as respostas obtidas da entrevista com as questões abertas e as perguntas fechadas.

Para atingir os objetivos da pesquisa, optou-se por incluir dois construtos: reputação e atribuição de legitimidade como possíveis resultados da competência política da liderança. A fim de elaborar as questões sobre reputação, a autora desta tese utilizou como base o livro Political Skill at work, de Ferris, Davidson e Perrewé (2005) pelo fato de esses autores tratarem a reputação como um conjunto de qualidades e habilidades individuais que podem ser classificadas como capital humano, capital social e capital político. $\mathrm{O}$ enfoque no aspecto político foi fator determinante para a escolha dessa referência. Para esses autores, a reputação é influenciada pelas características pessoais, o que inclui as competências políticas. Já a atribuição de legitimidade de um líder refere-se ao nível em que os outros acreditam que ele mereça gerir, ordenar e demandar suas ações e exercer influência. Para esse construto, utilizou-se um questionário pré-existente de Choi e Mai-Dalton (1999) sobre atribuição de legitimidade e também referências sobre legitimidade com o enfoque da Psicologia Social, que inclui as dimensões instrumental, relacional e moral (TYLER, 1997; TROST, 2011), conforme exemplo a seguir.

\section{Reputação}

1. Ele(a) é visto como um profissional que obtém bons resultados para a empresa. 
2. As pessoas sentem que ele(a) realiza coisas boas e importantes para a organização.

3. Ele(a) é visto como uma pessoa habilidosa.

4. As pessoas o(a) consideram uma pessoa confiável.

5. Ele(a) é admirado(a) e serve de exemplo para outras pessoas.

6. A experiência profissional dele(a) é reconhecida pelas pessoas.

7. Ele(a) tem um conhecimento notório na sua área.

8. Ele(a) é reconhecido por sua habilidade em perceber o ambiente e interagir socialmente.

9. Ele(a) é visto como um facilitador da interação social e união dos grupos.

\section{Atribuição de Legitimidade}

1. Eu quero que ele(a) continue em seu cargo.

2. Ele(a) merece a posição que ocupa.

3. Ele(a) facilita o alcance de metas.

4. Ele (a) se comporta de maneira ética.

5. Ele(a) trata a todos com dignidade e respeito.

6. Seus valores morais se parecem com os valores da organização.

Portanto, os questionários tiveram duas versões, uma para os gestores avaliarem suas próprias competências políticas, sua reputação e a atribuição de legitimidade, e a outra versão (pares, superiores e/ou profissionais de RH), que sofreu adaptações para permitir a avaliação da competência política, reputação e atribuição de legitimidade dos seus pares ou subordinados. Os itens "reputação" e "atribuição de legitimidade" tratam de construtos relacionados à percepção do outro. Mesmo com consciência da possível inadequação da avaliação desses itens por meio da autoavaliação, resolveu-se mantê-los, com o intuito de realizar uma comparação entre os aspectos de como as pessoas se avaliam e como são avaliadas.

As questões elaboradas sobre reputação e legitimidade foram utilizadas no estudo somente como apoio e sustentação par a análise qualitativa dos dados. O estudo não teve como objetivo utilizá-las para fins quantitativos ou para cálculos e modelos estatísticos sofisticados. Nessa segunda etapa do estudo, utilizaram-se apenas as estatísticas descritivas básicas (média, desvio padrão, coeficiente de variação e valores máximo e mínimo) para realizar a comparação entre a percepção dos diferentes atores. 


\subsubsection{Amostra}

A amostra foi selecionada por acessibilidade tanto para os estudos de caso quanto para o grupo de profissionais experientes. Foi realizado um contato inicial com algumas empresas e profissionais, com as quais a autora já possuía algum relacionamento profissional ou pessoal. Foram enviadas uma apresentação da pesquisa, uma carta de apresentação da pesquisadora e dos procedimentos de coleta de dados, assim como uma solicitação de autorização para realização de pesquisa. As empresas e profissionais que permitiram a realização da pesquisa demonstraram interesse pelo tema. Ao final da entrevista com os profissionais experientes, era solicitada a indicação de um profissional com perfil para realizar a pesquisa, sendo que muitos dos entrevistados foram indicados por outros.

A amostra foi selecionada de maneira intencional, incluindo os indivíduos que preenchiam os critérios previamente definidos a fim de assegurar que os resultados representassem adequadamente as percepções e concepções acerca do ambiente político e da competência política (MARSHAL; ROSSMAN, 1999; MAXWELL, 1996). O critério de escolha dos entrevistados foi que os profissionais tivessem experiência em cargos de gestão. No contato com as empresas, tentou-se acessar o nível mais alto possível e disponível, por se acreditar que a percepção e a atuação no ambiente político ficam mais intensas nos níveis mais altos da organização. Foram realizadas entrevistas isoladas com um grupo de profissionais donos do próprio negócio ou profissionais que ocuparam cargos altos nas organizações. O objetivo de realizar as entrevistas com esse grupo de profissionais se deu em razão da busca por profissionais com experiência sólida e vivência na "arena política" da organização e que tivessem mais liberdade para fornecer as informações, por não estarem vinculados a nenhuma organização.

A intenção dessas entrevistas foi também buscar um grau de variação nas percepções acerca da competência política das lideranças por meio da inclusão de empresas e de profissionais de diferentes setores da economia e de variados portes. Segundo Marshal e Rossman (1999), para definição da amostra em pesquisas qualitativas, uma das estratégias pode ser a busca por grande variação de visões, com o objetivo de documentar as diversas variações sobre o tema e de identificar, a partir daí, padrões comuns. Como a seleção da amostra se deu por processo não probabilístico, a escolha dos indivíduos visou maximizar a utilidade e profundidade das informações obtidas. 


\subsubsection{Perfil da amostra}

Foram realizados dois estudos de casos, conforme os QUADROS 2 e 3, a seguir.

Quadro 2 - Estudo de caso 1

\begin{tabular}{|l|l|}
\hline Ramo de atividade & Mineração \\
\hline $\mathbf{N}^{\circ}$ de funcionários & acima de 2.000 \\
\hline Tipo: & Empresa Privada \\
\hline Localização & Filial Belo Horizonte \\
\hline Nível hie rárquico dos entrevistados & Gerentes e Diretor RH \\
\hline
\end{tabular}

Fonte: Elaborado pela autora.

Nessa organização, foram entrevistados quatro gestores e o diretor de RH. Todos os entrevistados responderam às 12 perguntas abertas e fizeram a autoavaliação sobre sua competência política, conforme TAB. 4, a seguir.

Tabela 4 - Entrevistas Profissionais Estudo de Caso 1

\begin{tabular}{c|c|l|c|l|l|c}
\hline & $\begin{array}{c}\text { Tipo de } \\
\text { entrevista }\end{array}$ & \multicolumn{1}{|c|}{ Cargo } & idade & Gênero & Escolaridade & $\begin{array}{c}\text { Tempo de } \\
\text { Empresa }\end{array}$ \\
\hline 1.1 & face a face & Gerente de comunicação & 39 & Feminino & Especialização & 5 meses \\
\hline 2.1 & face a face & Gerente de Projetos & 48 & Masculino & Especialização & 4 anos \\
\hline 3.1 & face a face & Diretor de RH & 51 & Masculino & Doutorado & 3 meses \\
\hline 4.1 & face a face & Gerente de rel. trabalhistas & 34 & Masculino & Mestrado & 5 meses \\
\hline 5.1 & face a face & Gerente de Estratégia & 39 & Masculino & Mestrado & 3 anos \\
\hline
\end{tabular}

Fonte: Elaborada pela autora.

Quadro 3 - Estudo de caso 2

\begin{tabular}{|l|l|}
\hline Ramo de atividade & Financeiro \\
\hline $\mathbf{N}^{\circ}$ de funcionários & acima de 100.000 \\
\hline Tipo: & Emp. Economia Mista \\
\hline Localização & Brasília - DF \\
\hline Nível hie rárquico dos entrevistados & Gerentes executivos e Dir. RH \\
\hline
\end{tabular}

Fonte: Elaborado pela autora. 
$\mathrm{Na}$ empresa citada acima, foram entrevistados cinco gestores e o diretor de $\mathrm{RH}$ conforme TAB. 5, a seguir.

Tabela 5 - Entrevistas Profissionais Estudo de Caso 2

\begin{tabular}{c|c|c|c|c|c|c}
\hline & Tipo de entrevista & Cargo & idade & Gênero & Escolaridade & $\begin{array}{c}\text { Tempo de } \\
\text { empresa }\end{array}$ \\
\hline 1.2 & face a face & Gerente & 50 & Masculino & Especialização & 29 anos \\
\hline 2.2 & face a face & Gerente & 48 & Masculino & Especialização & 34 anos \\
\hline 3.2 & face a face & Gerente & 56 & Masculino & Mestrado & 29 anos \\
\hline 4.2 & face a face & Gerente & 53 & Feminino & Mestrado & 32 anos \\
\hline 5.2 & face a face & Gerente & 47 & Masculino & Especialização & 33 anos \\
\hline 6.2 & Video conferência & Diretor & 50 & Masculino & Especialização & 32 anos \\
\hline
\end{tabular}

Fonte: Elaborada pela autora.

No segundo bloco de entrevistas, foram entrevistados donos do próprio negócio e profissionais que já haviam ocupado altos cargos em diferentes organizações, mas que, no momento, por diferentes razões, não estavam atuando no mercado de trabalho e que, portanto, teriam mais liberdade para tratar da temática. A única exceção foi um profissional que atualmente ocupa um cargo importante em uma empresa, mas que, por atuar também na área acadêmica, disponibilizou-se a responder às perguntas como contribuição à pesquisa. Esse grupo de entrevistados foi denominado pela autora de "profissionais experientes", conforme TAB. 6, a seguir.

\begin{tabular}{l} 
Tabela 6 - Entrevistas Profissionais experientes \\
\hline
\end{tabular}

Fonte: Elaborada pela autora. 
Em seguida, apresenta-se a TAB. 7, que mostra a relação geral dos gestores entrevistados com o tempo de duração das entrevistas.

\begin{tabular}{|c|c|c|c|c|c|c|c|}
\hline & Tipo de entrevista & Cargo & idade & Gênero & Escolaridade & $\begin{array}{c}\text { Tempo de } \\
\text { empresa }\end{array}$ & $\begin{array}{c}\text { Duração da } \\
\text { entrevista }\end{array}$ \\
\hline 1 & Profissional Experiente & Vice Presidente de RH & 56 & Masculino & Doutorado & 21 anos & e-mail \\
\hline 2 & Profissional Experiente & Diretor Regional & 62 & Masculino & Doutorado & 5 anos & $50 \mathrm{~min} 31 \mathrm{~s}$ \\
\hline 3 & Profissional Experiente & Presidente & 63 & Masculino & Mestrado & 6 anos & $35 \min 17 \mathrm{~s}$ \\
\hline 4 & Profissional Experiente & Superintendente Comercial & 54 & Masculino & Mestrado & 11 anos & $1 \mathrm{~h} 29 \mathrm{~min}$ \\
\hline 5 & Profissional Experiente & Vice Presidente & 78 & Masculino & Graduação & 40 anos & $1 \mathrm{~h} 41 \mathrm{~min}$ \\
\hline 6 & Profissional Experiente & Diretor Proprietário & 61 & Masculino & Especialização & 32 anos & $1 \mathrm{~h} 6 \mathrm{~min}$ \\
\hline 7 & Profissional Experiente & Diretora de RH & 64 & Feminino & Especialização & 27 anos & $1 \mathrm{~h} 20 \mathrm{~min}$ \\
\hline 8 & Profissional Experiente & Diretor Proprietário & 58 & Masculino & Graduação & 27 anos & $56 \min 14 \mathrm{~s}$ \\
\hline 9 & Profissional Experiente & Vice de Presidente de RH & 70 & Masculino & Especialização & 15 anos & $1 \mathrm{~h} 52 \mathrm{~min}$ \\
\hline 10 & Profissional Experiente & Diretor de RH & 42 & Masculino & Mestrado & 2 anos & $51 \mathrm{~min} 19 \mathrm{~s}$ \\
\hline 11 & Estudo de Caso 1 & Gerente de comunicação & 39 & Feminino & Especialização & 5 meses & $43 \mathrm{~min}$ \\
\hline 12 & Estudo de Caso 1 & Gerente de Projetos & 48 & Masculino & Especialização & 4 anos & $57 \min 58 s$ \\
\hline 13 & Estudo de Caso 1 & Diretor de RH & 51 & Masculino & Doutorado & 3 meses & $39 \min 58 \mathrm{~s}$ \\
\hline 14 & Estudo de Caso 1 & Gerente de Rel. Trabalhistas & 34 & Masculino & Mestrado & 5 meses & $57 \min 2 s$ \\
\hline 15 & Estudo de Caso 1 & Gerente (Head of Strategy) & 39 & Masculino & Mestrado & 3 anos & $35 \min 12 s$ \\
\hline 16 & Estudo de Caso 2 & Gerente Executivo & 50 & Masculino & Especialização & 29 anos & $1 \mathrm{~h} 19 \mathrm{~m}$ \\
\hline 17 & Estudo de Caso 2 & Gerente Executivo & 48 & Masculino & Especialização & 34 anos & $1 \mathrm{~h} 47 \mathrm{~m}$ \\
\hline 18 & Estudo de Caso 2 & Gerente Executivo & 56 & Masculino & Mestrado & 29 anos & $1 \mathrm{~h} 14 \mathrm{~m}$ \\
\hline 19 & Estudo de Caso 2 & Gerente Executivo & 53 & Feminino & Mestrado & 32 anos & $57 \mathrm{~m} \mathrm{32s}$ \\
\hline 20 & Estudo de Caso 2 & Gerente Executivo & 47 & Masculino & Especialização & 33 anos & $43 \mathrm{~m} 10 \mathrm{~s}$ \\
\hline 21 & Estudo de Caso 2 & Diretor de RH & 50 & Masculino & Especialização & 32 anos & $51 \mathrm{~m}$ \\
\hline
\end{tabular}

Fonte: Elaborada pela autora.

A quantidade de entrevistados não foi previamente definida, pois optou-se por considerar como quantidade adequada aquela a partir da qual os temas se tornassem intensamente recorrentes. Foi entrevistado um total de 21 profissionais em cargos de gestão, sendo: um presidente, três vice-presidentes, sete diretores, um superintendente, nove gestores. Em relação à formação dos entrevistados, a maioria, 76\%, tem a formação em nível de mestrado e especialização. Os ramos de atividade das empresas foram variados, e a área de atuação dos profissionais apresentou um leve predomínio da área de Recursos Humanos. Apenas 15\% dos entrevistados são do gênero feminino. A idade média dos entrevistados é de 53 anos. 


\subsection{Análise dos dados}

As entrevistas foram avaliadas por meio da análise de conteúdo, que busca a essência de um texto nos detalhes das informações, dados e evidências disponíveis. A análise de conteúdo não trabalha com o texto per se, mas também com detalhes do contexto. $\mathrm{O}$ interesse não se restringe à descrição dos conteúdos. Deseja-se inferir a partir do todo da comunicação. Entre a descrição e a interpretação interpõe-se a inferência. Buscam-se entendimentos sobre as causas e antecedentes da mensagem, bem como seus efeitos e consequências (MARTINS; THEÓFILO, 2016). Uma análise de conteúdo foi efetuada a partir das entrevistas. Para isso, os textos transcritos de todas as entrevistas foram divididos em categorias temáticas. O método de análise se dividiu em duas etapas: primeiramente, foram identificados os temas relacionados às proposições, em seguida as unidades de registro foram agrupadas às perguntas utilizadas para responder às proposições elaboradas. Essas unidades de registro foram constituídas por enunciados ou trechos dos textos transcritos que traziam significações que pudessem ser isoladas (BARDIN, 1977). Por isso, os temas com o mesmo significado e que remetiam ao mesmo conceito foram reunidos. É importante ressaltar que as categorias formadas são mutuamente excludentes, homogêneas em si e pertinentes ao objetivo do estudo e que os trechos dos textos serviram como "guias" para a formação e análise da percepção sobre o ambiente político e a competência política dos gestores.

A análise dos dados constitui o processo de ordenação, estruturação e interpretação da massa de dados obtida na pesquisa. Os dados qualitativos são complexos e sua conversão para medidas ou unidades padronizadas não é automática ou rápida. Isso acontece porque, geralmente, os dados obtidos variam em termos de abstração, frequência de ocorrência e relevância para os propósitos do estudo (MARSHALL; ROSSMAN, 1999). Para a apresentação de alguns resultados, foram elaboradas algumas tabelas. Obtivem-se quase todas as respostas do questionário com escala do tipo Likert sobre competência política, reputação e atribuição de legitimidade dos profissionais entrevistados, com exceção de um profissional que fez a avaliação dos seus pares, mas não fez a própria avaliação.

A análise dos dados foi realizada em três etapas:

I. Coleta das evidências empíricas por meio de entrevistas e aplicação de questionário com escala do tipo likert escala 7 sobre competência política, reputação e legitimidade. As entrevistas tiveram a duração média de uma hora 
e foram realizadas pelo mesmo entrevistador - a autora deste estudo. As entrevistas foram gravadas, transcritas e enviadas para aprovação dos entrevistados. No envio das transcrições aos entrevistados, foi inserida uma mensagem em que se avisava que, caso nenhum retorno fosse dado em 15 dias, interpretar-se-ia que o entrevistado estava de acordo com a transcrição. Somente dois entrevistado fizeram pequenos ajustes no seu texto, mas que não estavam relacionados ao contexto em si.

II. Identificação de temas - a partir dos textos transcritos das entrevistas foram identificados os temas que possivelmente compunham as respostas para as proposições elaboradas no presente estudo e que serão apresentadas em seguida no item Método. Conforme Bardin (1977), um tema constitui uma unidade de significação complexa e de comprimento variável, cuja validade não é de ordem linguística, mas sim de ordem psicológica. Podem constituir um tema tanto uma afirmação quanto uma alusão. Assim, as frases, os enunciados ou trechos dos textos transcritos que traziam significações que pudessem ser isoladas foram considerados temas. A identificação de temas constitui uma etapa importante no estudo, já que a partir deles se torna possível a identificação de crenças, tendências e valores contidos nas mensagens dos entrevistados (BARDIN, 1977).

III. Formação das categorias temáticas - depois de identificados, os temas foram agrupados em categorias temáticas. Essas categorias foram relacionadas às proposições do estudo. Os critérios para formação das categorias foram semânticos, ou seja, os temas que possuíam os mesmos significados e que remetiam aos mesmos conceitos foram reunidos na mesma categoria. $O$ referencial teórico também foi utilizado como "guia" nesse processo.

A seguir, apresentam-se a técnica e o método utilizados.

\subsection{Técnica}

Para avaliação das entrevistas, foi utilizada a técnica de análise de conteúdo. Segundo Bardin (1977), a análise de conteúdo constitui uma técnica de análise 
sistemática das comunicações com o objetivo de alcançar a descrição do conteúdo das mensagens e indicadores, sejam eles qualitativos ou não e que possibilitem a inferência de conhecimentos relacionados às mensagens, sua condição de produção e recepção. Um conjunto de técnicas de análise das comunicações visando obter, por procedimentos sistemáticos e objetivos de descrição do conteúdo das mensagens, indicadores quantitativos ou não - que permitam a inferência de conhecimentos relativos às condições de produção e recepção destas mensagens". A análise realizada foi transversal, uma vez que as entrevistas foram recortadas em torno dos temas identificados. Foram utilizados trechos das falas para exemplificar os achados por temas do estudo. Essa técnica se mostrou conveniente para os propósitos do presente trabalho, por sua característica de agilidade e eficácia para aplicação em discursos diretos e simples como as entrevistas (BARDIN, 1977).

\subsection{Método}

Nesta pesquisa, utilizaram-se métodos mistos. A parte quantitativa se deu por meio da validação de questionário para o português e aplicação de um questionário do tipo likert escala 7 para avaliação dos itens competência política, reputação e legitimidade. Na parte qualitativa, foram realizadas entrevistas abertas com gestores profissionais atuantes nas empresas em que se realizaram os estudos de caso e de profissionais experientes. A escolha do método de estudo de caso na presente pesquisa se justifica em razão dos objetivos do estudo, em que se buscou avaliar como a competência política contribui para o desenvolvimento na carreira de um profissional, na aquisição de uma boa reputação e na atribuição de legitimidade das lideranças. Para tanto, foram elaboradas quatro proposições. Inicialmente, elaborou-se a Proposição 1 As lideranças brasileiras consideram-se e são percebidas (por pares, superiores, gestores de RH) como politicamente competentes. O estudo nas organizações permitiu aos profissionais realizarem uma autoavaliação nesses quesitos, mas também que outros profissionais da mesma empresa pudessem avaliá-lo nessas questões, de modo que foi possível comparar a autoavaliação com a percepção do outro em relação à competência política, reputação e atribuição de legitimidade. A busca pela percepção dos outros membros do grupo em relação a essa competência é uma forma de reduzir uma crítica comum aos estudos sobre competência política, que são baseados apenas em 
autorrelato, mas, principalmente, por essa ser uma competência relacionada à efetividade social, e a percepção dos outros atores ser importante.

A fim de compreender essas questões, foram usadas as respostas obtidas para as perguntas de número 5 - Identifique uma situação em que o $\operatorname{Sr}(a)$ precisou da competência política para atuar em uma negociação ou lidar com um conflito ou uma disputa. Qual era a situação? O que antecedeu o problema? Como foi o processo de resolução do problema? Qual foi o resultado? e de número 7 - O Sr.(a) se classificaria como um profissional competente politicamente? Se sim, isso ajudou? Se não, fez falta? Por quê?

Eisenhardt (1989) considera que o estudo de caso possibilita avaliar as questões com profundidade, a fim de entender como, quando e por que um fenômeno ocorre. A percepção mais comum do comportamento político é, sem dúvida, disfuncional. Os estudos sobre o comportamento político, normalmente, ignoram os aspectos funcionais e positivos para os indivíduos, grupos e organizações. Alguns pesquisadores, entretanto, consideram a política nas organizações como mais próxima a um conceito neutro. A natureza positiva ou negativa do comportamento pode ser vista em razão da atribuição da intenção dos seus atores ou aos resultados pessoais e organizacionais associados a ele (DAVID; GARDNER, 2004; FERRIS et al., 2002; FEDOR et al., 2008). Apesar de a política fazer parte do cotidiano das organizações, muitas vezes, o termo é pouco utilizado. Outro ponto importante é introduzir a perspectiva positiva e não negativa, como é popularmente reconhecida, a fim de facilitar a abertura para as discussões sobre o tema. Elaborou-se, portanto, a Proposição 2 - Os aspectos positivos do ambiente político nas organizações e da função política do gestor são percebidos pelos profissionais brasileiros. Para tentar avaliar essa proposição utilizaram-se as seguintes perguntas da entrevista: pergunta 1) Ao assumir cargos mais altos na organização, o profissional passa a lidar mais intensamente com os conflitos de interesse, disputas por espaço, recursos, reconhecimento e negociações. O que o Sr.(a) pensa sobre esse aspecto da função do executivo?; pergunta 2) Como o Sr.(a) descreveria o ambiente político da organização?; pergunta 9) O comportamento político pode ser percebido de diferentes maneiras em razão da intenção e resultados das ações dos seus atores. Exemplifique como e quando alguns profissionais podem utilizar esse comportamento de maneira funcional ou disfuncional.; pergunta 10) Em sua opinião, qual a melhor forma de incentivar o comportamento político funcional? E qual a melhor maneira de inibir o comportamento político disfuncional? 
Segundo Yin (2009), o estudo de caso possibilita a observação de um fenômeno em seu contexto real, principalmente quando os limites entre o fenômeno e seu contexto não sejam tão facilmente delimitados. Esse método possibilita ainda que o pesquisador trabalhe com diferentes variáveis e busque múltiplas fontes de evidência ou vários pontos de vista, permitindo a triangulação. Nesta pesquisa, pretendeu-se traçar a relação entre os construtos competência política, reputação e legitimidade. Para tal, elaborou-se a Proposição 3: As características de uma boa reputação e atribuição de legitimidade podem ser associadas às características de líderes considerados competentes politicamente. A fim de identificar essas características, utilizaram-se as respostas dadas às seguintes perguntas: pergunta 3) Descreva as características de um profissional competente politicamente; pergunta 11) O que gera uma boa reputação para uma liderança?; pergunta 12) Para o $\operatorname{Sr}(a)$, o que significa um líder legítimo? As relações só podem ser traçadas caso exista uma compreensão profunda do tema, o que é possibilitado pelo estudo de caso.

Outro objetivo da pesquisa foi avaliar o papel do contexto, ou seja, da cultura da organização. Para tanto, foram escolhidos casos tanto em instituições privadas quanto em empresas de economia mista. A opção por esses dois tipos de instituições para realização da pesquisa teve o intuito de verificar como a temática é percebida e como a competência política é vista nesses dois ambientes. A literatura sobre o tema mostra que a questão do contexto pode influenciar o modo como a competência política é utilizada e percebida. Ao mesmo tempo, buscou-se verificar se a relação entre os construtos "competência política", "aquisição de boa reputação" e "atribuição de legitimidade" produz resultados similares em todas as organizações pesquisadas, independentemente do contexto em que estão inseridas. Ciente da limitação dessa análise, em razão da existência de apenas um caso de cada tipo de organização, a pesquisadora contentou-se em discutir algumas poucas questões mais genéricas e restritas ao contexto e apontar a necessidade de estudos futuros.

De acordo com Flybjerg (2006), o estudo de caso permite um aprendizado mais prático e mais concreto. O estudo de caso é uma boa ferramenta para gerar proposições que poderão ser testadas, além de poder também gerar proposições e teorias baseadas em estudos de casos específicos. Na tentativa de avaliar como a competência política é compreendido no cenário nacional, elaborou-se a Proposição 4: As organizações brasileiras e seus profissionais reconhecem a importância da competência politica no desenvolvimento da carreira dos seus gestores. Para tentar compreender esses aspectos, 
utilizaram-se as seguintes perguntas do questionário: Pergunta 4) Na seleção ou promoção de profissionais para sua equipe, além dos aspectos técnicos, as questões dos relacionamentos sociais e políticos eram levadas em consideração? Por quê?; Pergunta 6: $\mathrm{O} \mathrm{Sr}(\mathrm{a})$ recebeu algum treinamento ou foi exposto a situações que lhe permitissem o desenvolvimento de competências políticas, antes de assumir seu cargo?; Pergunta 8) Em um momento de conflito muito acirrado, como o problema era resolvido na empresa?

As fontes de evidência utilizadas para a realização dos estudos de caso foram entrevistas semiestruturadas realizadas com gestores, superiores, profissionais de Recursos Humanos e com profissionais experientes; observação direta realizada pela pesquisadora durante o processo de coleta de dados que foram consolidadas em notas de campo e questionários preenchidos pelos pesquisados sobre os construtos "competência política", "competência política", "aquisição de boa reputação" e "atribuição de legitimidade". Inicialmente, pensou-se em utilizar as avaliações de desempenho dos respondentes como dados secundários, mas não se conseguiu acesso a esse material.

O procedimento de coleta de dados levou em consideração os quatro princípios da coleta de dados sugerida por Yin (2009). O primeiro princípio é a utilização de múltiplas fontes de evidência, como foi exemplificado acima, com o objetivo de buscar a convergência de evidências para realizar a triangulação dos dados, uma vez que as múltiplas fontes proporcionam várias avaliações do mesmo fenômeno. Neste estudo, conseguiu-se, em alguns casos, que a competência política fosse avaliada pelo próprio gestor, seus pares e superiores. O segundo princípio é a criação de uma base de dados do estudo de caso que tratou da transcrição das entrevistas e seu arquivamento, assim como do arquivamento dos questionários respondidos, além das tabelas elaboradas na consolidação dessas informações, que também estão disponíveis para consulta posterior. Como terceiro princípio, tem-se a manutenção do encadeamento das evidências. Nesta pesquisa, esse princípio foi atendido, já que os processos de busca de evidência foram traçados por meio da descrição das fontes relevantes para cada descoberta, como as passagens das entrevistas e das observações específicas. O quarto princípio é a utilização cuidadosa de dados de fonte eletrônica. Os meios eletrônicos foram utilizados neste trabalho apenas no processo de coleta de respostas dos questionários durante a validação do questionário (PSI - Political Skill Inventory). 


\section{APRESENTAÇÃO DOS DADOS}

A coleta dos dados teve como objetivo responder às proposições feitas durante a elaboração do trabalho: Proposição 1 - As lideranças brasileiras consideram-se e são percebidas (pares, superiores, gestores de RH) como politicamente competentes. Proposição 2 - Os aspectos positivos do ambiente político nas organizações e da função política do gestor são percebidos pelos profissionais brasileiros. Proposição 3: As características de uma boa reputação e atribuição de legitimidade podem ser associadas às características de líderes considerados competentes politicamente. Proposição 4: As organizações brasileiras e seus profissionais reconhecem, a importância da competência política no desenvolvimento da carreira dos seus gestores. Primeiramente, fez-se a análise das respostas obtidas nas entrevistas com as 12 perguntas abertas, para só então se discutirem as proposições no capítulo Conclusão.

Serão discutidas, em seguida, as respostas do roteiro de entrevistas, seguindo a ordem em que as perguntas foram expostas aos entrevistados. A primeira questão foi " $O$ que os gestores pensam sobre a função política do cargo de gestor?" Segundo Dutra (2010), a carreira de gerente implica a atuação na "arena política" da organização. No entanto é sabido que nem todo bom profissional técnico ou funcional tem perfil para atuar nessa "arena". Alguns profissionais não valorizam a área e, portanto, têm dificuldade de se desenvolverem nas atividades políticas. Segundo Mintzberg (1983), para sobrevivência e efetividade nas organizações são necessárias vontade e habilidade política. Esperava-se que profissionais com perfil de liderança ou com competência política desenvolvida considerassem esse aspecto da função como natural e importante, por apresentarem vontade e competência política. E, por outro lado, que profissionais sem vontade ou com competência política pouco desenvolvida interpretassem esse aspecto da função de forma negativa, ou seja, como algo cansativo e desconfortável. A seguir, apresentam-se trechos das falas dos gestores que mostram a sua visão sobre o aspecto político da função dos gestores.

"Esse aspecto é fundamental. Não é possível exercer o papel de gestor sem construir relações e sem estabelecer espaços de influência. Isso é algo inerente à função de gerir." (Profissional 3.1)

"Esse talvez seja um dos papéis mais relevantes de um executivo. Evitar o conflito, seja de interesse técnico ou dos 
mais diversos tipos de interesse. Essa é uma das questões mais importantes para o executivo na organização. O conflito é inerente à condição e à convivência humana. As pessoas têm projetos, agendas, visões muito específicas. Se os conflitos não forem resolvidos, a situação piora, é preciso resolver ou administrar para ter uma convivência razoável." (Profissional Experiente 2)

“A dimensão política da função vai se tornando cada vez mais importante conforme se sobe na hierarquia da empresa. As questões vão ficando mais genéricas e estratégicas, surgem decisões que começam a envolver mais valores do que conhecimento técnico e o profissional precisa aprender (ou desenvolver) essa competência." (Profissional Experiente 1)

"Eu concordo plenamente com essa complexidade da função do líder. Ao se alcançarem postos mais elevados na organização, a importância relativa das competências técnicas diminui enquanto a importância das competências relacionais aumenta. As competências técnicas continuam sendo importantes, mas perdem importância relativa enquanto as competências políticas e relacionais ganham uma importância maior. Compreender isso é fundamental para o sucesso da liderança." (Profissional 3.2)

"O grande desafio das lideranças, dado que há boas estratégias e profissionais qualificados, é mobilizar os funcionários; isso que dá o tempero à organização. As lideranças lidam com pessoas que têm seus próprios objetivos de crescerem na empresa, de serem promovidas etc. Nesse contexto, disputas são normais principalmente em organizações que tenham dezenas, centenas ou milhares de funcionários; isso é humano. As lideranças, portanto, precisam fazer com que essas contradições, que são naturais, possam alavancar a empresa." (Profissional Experiente 3)

"Ao longo da nossa trajetória, somos obrigados a lidar com disputas e conflitos de interesse. Naturalmente, quando há uma ascensão, essas questões se tornam mais acirradas. Contudo, se o gestor tiver clareza e conseguir criar um ambiente de diálogo, as situações se dissolvem de forma relativamente simples. Quando o gestor é transparente, até na hora de impor condições de restrição, os problemas são resolvidos mais facilmente." (Profissional 2.2)

"Posso dizer que disputas por poder, por espaço e por colocação sempre existiram na minha vida, e essas experiências ajudaram a forjar o profissional que sou hoje. Obviamente, ao longo da carreira, aprendemos a nos impor e a nos colocar de forma menos autoritária. $\mathrm{O}$ conhecimento técnico e a experiência nos ensinam como nos situar melhor no ambiente corporativo. 
Aprendemos que nada é absoluto. As coisas podem ser mudadas; há sempre outras opiniões.” (Profissional 2.1)

"Quando você assume uma posição hierarquicamente mais alta em uma empresa, naturalmente, surgem conflitos e disputas de interesse. Toda empresa que tem hierarquia tem competição. Mesmo que o funcionário não queira se tornar presidente, ele quer estar bem diante dele e quer passar uma boa impressão, mesmo que seja apenas uma disputa pelo amor do chefe." (Profissional Experiente 5)

"Quando você assume cargos mais altos, como o de superintendente, é preciso brigar por gerente, por visitas técnicas, por recursos, pela atenção da diretoria. Havia também um sistema de avaliação de profissionais que analisava resultados e comportamentos individuais e eliminava periodicamente os que estivessem nos últimos lugares do ranking. Necessariamente, alguém sairia. Todos os profissionais, seus superiores e subordinados, enfrentam essa situação. Quanto mais você sobe, mais você representa um papel." (Profissional Experiente 4)

A maioria dos depoimentos considera a função política como uma das atividades mais importantes dos gestores. No entanto alguns profissionais, mesmo conscientes da importância desse aspecto da gestão, expuseram suas dificuldades em relação a ele.

"Esse aspecto é bastante cansativo. Na empresa em que trabalho atualmente, a disputa é constante. Trabalhei em outras organizações em que a competitividade não era tão acentuada; isso depende muito da cultura da empresa. Temos que saber lidar com vaidades, disputas e até com desonestidade. Acontece de pessoas tentarem roubar ideias alheias. Há também pessoas que usam do setor de Comunicação para se autopromover. Contudo isso faz parte da função do gestor.” (Profissional 1.1)

"Ficou muito evidente que, quanto mais o profissional ascende na pirâmide hierárquica, as questões de disputa e de visibilidade se tornam mais presentes, mais intensas, embora nem sempre elas sejam expressas. Essas relações de poder não se travam de forma explícita. Elas são, na maioria das vezes, veladas. Eu tive que aprender a captar e a compreender esses aspectos sutis. Eu não me considero uma profissional competente politicamente. $\mathrm{Eu}$ digo isso pesarosa, por um lado, mas aliviada por outro. E, nesse caso, estou olhando por uma perspectiva negativa das habilidades políticas. Eu não acho que a competência política 
seja, necessariamente, ruim. Falando em redes de relacionamentos, por exemplo, eu as considero um componente importante dentro dessa competência. No entanto, eu não tenho facilidade em criar grupos de relacionamento, talvez por ser uma pessoa mais reservada. Tenho uma dificuldade absurda nesse quesito". (Profissional 4.2)

Foi proposto aos entrevistados que descrevessem o ambiente político da organização. Com base na teoria, imaginava-se que os profissionais percebem o ambiente político como um fato na organização e que é preciso saber lidar com esses aspectos para alcançar a efetividade na organização. Apresentam-se, a seguir, alguns trechos das entrevistas dos profissionais com suas descrições sobre o ambiente político da organização:

"A organização é um conjunto de pessoas, e um conjunto de grupos de interesses distintos. $\mathrm{O}$ acionista gostaria de maximizar o retorno do investimento. Já os empregados ou executivos querem maximizar seu próprio ganho. Às vezes, esses interesses se chocam. Por isso se criou a Governança Corporativa e o Conselho de Administração. Embora o Conselho seja importante para mediar conflito e resolver os problemas de agência, ele é mais um elemento que coloca gente, que por sua vez coloca ideias, pontos de vistas e vieses, ou seja, grupos com interesses conflitantes. A organização já nasce com conflito. Muitas vezes, as empresas, ao criarem mecanismos para resolver um conflito, acabam criando novos conflitos.” (Profissional Experiente 2)

“O ambiente é claramente político. Há disputas, brigas de poder. Entretanto isso pode gerar uma tensão positiva na empresa. $\mathrm{O}$ fato de as pessoas não serem acomodadas e quererem crescer na organização não é negativo. Se a liderança for hábil para gerenciar esses conflitos, eles podem tornar-se uma tensão positiva. Discordâncias e pequenos conflitos acontecem no cotidiano das empresas. Vejamos pelo outro lado, se todos os funcionários fossem um Yes man, se todos fossem acomodados, não haveria um ambiente político. As pessoas, simplesmente, obedeceriam. Podemos até dizer que o ambiente fosse político, mas como uma tirania ou ditadura." (Profissional Experiente 3)

"Os universos das organizações são absurdamente políticos. De fato, quando ocorre a ascensão profissional, os espaços tornamse mais complexos. Para lidar com esse conjunto de situações, como disputas por reconhecimento e conflitos de interesse, é necessário conhecer a cultura da organização. No mundo corporativo, se você chegar no momento errado ou se fizer uma leitura equivocada, sua carreira na empresa está ameaçada. Eu 
precisei lidar com um ambiente de crise, de cortes e de tensão, em que os movimentos políticos para se manter na organização eram constantes. Eu tinha um colega que dizia que nós ficaríamos com os dedos grossos de tanto costurar, ou seja, ele se referia ao aspecto político que era permanente e essencial para nosso sucesso. O tempo todo, nós tínhamos que conversar, explicar e convencer." (Profissional experiente 9)

Nos trechos acima, os gestores demonstraram uma visão de que o ambiente é claramente político em razão de diferentes ideias, interesses, conflitos e disputas por espaço, recursos, reconhecimento e poder. A seguir, apresentam-se alguns depoimentos que se referem aos fatores que influenciam o ambiente, afetando sua intensidade e tipos de atividade política.

"O ambiente da organização onde trabalhei variava de acordo com a liderança. Um CEO pode trabalhar mais num ambiente de cooperação ou mais com uma dinâmica de competição e confronto. Do meu ponto de vista, experimentei essas duas formas de convivência profissional. A primeira é mais positiva e demanda mais comprometimento, enquanto a segunda, mais comum em tempos turbulentos ou difíceis, tende a buscar os limites dos envolvidos na tomada de decisão - limites psicológicos e eventualmente morais." (Profissional Experiente 1)

"Quando há transparência e critérios de meritocracia bem definidos, os conflitos são extirpados mais facilmente. Quando os funcionários percebem e acreditam que a competição é limpa, transparente e leal, cria-se uma tensão, uma força que impulsiona a empresa." (Profissional Experiente 3)

"Quando as pessoas percebem que estão trabalhando em equipe por um objetivo comum e por um crescimento mútuo, a competitividade vai para segundo plano. A divergência não desaparece, mas a competição diminui." (Profissional 2.2)

“A competência política está muito associada ao ambiente em que o profissional está inserido. Ser competente politicamente, olhando pelo ponto de vista da cultura dessa organização, significa continuar tocando as notas que a empresa toca. Inserir uma nova nota no seu processo de trabalho requer muito cuidado. Competência política envolve trabalhar essas duas dimensões concomitantemente. A competência política é a capacidade de respeitar valores culturais e de colocar em xeque uma série de questões que precisam ser revistas na empresa. $\mathrm{O}$ profissional que não agir dessa forma não ajudará a empresa a se transformar e estará assumindo uma postura individualista." (Profissional 2.2) 
$\mathrm{Na}$ descrição dos profissionais sobre o ambiente político, fica evidente que alguns fatores como contexto (cultura da organização), estruturação e estilo da liderança influenciam o ambiente. Muitos gestores que tiveram experiências em empresas com culturas distintas, sejam mais competitivas, sejam mais colaborativas, indicaram a existência de uma demanda por comportamentos diferentes em cada uma delas. Em um ambiente de maior competição, as disputas são mais intensas. $O$ ambiente de competição muito acirrado foi visto por vários dos entrevistados como um espaço mais propício ao surgimento de comportamentos políticos disfuncionais, conforme retratam as passagens a seguir:

“A disputa é brutal, principalmente na organização onde trabalhei. Minha carreira foi muito rápida. Eu comecei como gerente de contas e, poucos anos depois, tornei-me superintendente. Nós, que éramos por volta de quarenta superintendentes, fomos chamados pelo diretor e ele nos comunicou que a empresa precisava passar por mudanças para se tornar mais rápida, competitiva e eficiente. Ele disse também que o número de superintendentes seria reduzido pela metade, mas que os que permanecessem seriam muito bem recompensados financeiramente. Nós, da fase anterior à incorporação da outra instituição, não estávamos acostumados com isso. A empresa dá coisas impagáveis e proporciona momentos inesquecíveis, mas exige de você um sanguezinho diário. Resumidamente, posso dizer que a cultura organizacional mudou, o perfil dos diretores mudou. Isso foi bom em termos de resultado, mas, olhando em longo prazo, não tenho certeza. Muitos discursos eram de construção, mas a ação visava à comissão no fim do ano, que podia ser de quinhentos mil ou de um milhão." (Profissional Experiente 4)

"Uma vez eu trabalhei numa grande empresa que precisava, desesperadamente, de fazer caixa naquele ano e, para alcançar essa meta, eles prometeram um bônus de até 30 salários. Era muito dinheiro envolvido. O que se criou de conflito foi enorme. Para atender uma demanda a empresa criou distorções. $\mathrm{O}$ clima de competição era grande. As pessoas não se preocupavam com os clientes, a preocupação e o interesse eram o bônus. É uma gestão permanente de conflitos." (Profissional Experiente 2)

Nas descrições dos ambientes, percebe-se que, nos ambientes mais autoritários, burocráticos e autocráticos, as funcionalidades do sistema de influência político são mais restritas, o que faz com que as pessoas se importem menos com as relações. Fica evidente que, nesses ambientes, os profissionais não conseguem "furar" os degraus 
hierárquicos, o que impede, portanto, o papel positivo do sistema político de influência nas organizações. Segundo Mintzberg (1985), o papel positivo do sistema político de influência pode inibir a promoção de um único ponto vista e a submissão dos liderados por permitir o acesso a canais alternativos de informação e promoção, impedindo que líderes fracos abafem subordinados fortes. Veja-se uma descrição desse tipo de ambiente:

\begin{abstract}
"Aqui na empresa se você tiver um chefe incompetente, por exemplo, ele continuará seu chefe durante toda sua carreira. Crescer mais do que o chefe é impossível. A hierarquia é militar e a empresa é muito burocrática. Embora as decisões sejam colegiadas, a hierarquia sobressai. Tudo isso fortalece uma posição de omissão, de incompetência e de descomprometimento, apesar de o quadro funcional ser muito qualificado." (Profissional 4.2)
\end{abstract}

Nesse mesmo sentido, um dos entrevistados descreve a questão do contexto e a influência das questões culturais brasileiras que afetam o ambiente político, conforme ilustra o trecho a seguir:

"Eu creio que alguns hábitos estão relacionados à cultura empresarial brasileira. A pessoa tem a oportunidade de se posicionar em uma reunião, mas prefere não se expor. Além disso, frequentemente, os profissionais não estão preparados para receber críticas e para lidar com divergências, o que gera outro grave problema. As conversas paralelas são alimentadas quando os líderes da organização não estão abertos e aptos a entender as diversas opiniões. Em muitos casos, seria possível realinhar essas opiniões porque o profissional que as propôs não está tendo uma visão global da organização. Os profissionais brasileiros têm dificuldade em distinguir a vida profissional da vida pessoal. Você pode não gostar de uma pessoa fora da organização, mas, no contexto profissional, você precisa aprender a trabalhar com ela. É necessário estabelecer relações de respeito e de parceria com todos os profissionais. Contudo as organizações vêm tentando minimizar esse aspecto, embora ele não esteja eliminado, principalmente porque a cultura latina é bastante informal. As pessoas gostam de falar da vida do outro e esse hábito é trazido para a organização. Como nós não preparamos o profissional nem para as primeiras gestões, quando essa pessoa chega a níveis mais altos na hierarquia organizacional, ela não está preparada para receber críticas e para construir uma empresa sem interesses pessoais. Nós vivemos em uma cultura de instabilidade e uma cultura onde 
existe certo mimo dos pais em relação aos filhos. Juntando esses aspectos culturais com o despreparo dos líderes, surgem as brigas e os conflitos, em que o perdedor é sempre a organização." (Profissional experiente 10)

Por outro lado, os ambientes considerados mais democráticos, em que as políticas são claras sobre as promoções e oportunidades de carreira e as ideias discutidas foram identificadas como geradoras de um ambiente mais cooperativo e de um comportamento político mais funcional. Os ambientes democráticos foram descritos da seguinte maneira:

“A organização que apresenta um ambiente político democrático é mais saudável. Os funcionários trabalham com mais vontade. As regras são claras, discutidas, debatidas e as pessoas creem no primado dessas normas. Isso gera uma ambição positiva no funcionário. Ele percebe que seu esforço e sua determinação o farão crescer na organização. Essa ambição, quando aliada ao respeito, é completamente legítima. É mais fácil liderar uma empresa em um ambiente autoritário do que em um ambiente democrático. Porém, naquele falta a alma, a energia da empresa." (Profissional Experiente 3)

"Em empresas onde há regras para tudo, é muito mais fácil fazer a gestão. $\mathrm{Na}$ organização onde trabalhei, não existiam muitas normas. $\mathrm{O}$ emocional das pessoas era considerado um fator determinante. Portanto era necessário ter um cuidado grande com as pessoas. Nós não tínhamos códigos de conduta ou coisas do tipo, contudo nunca tivemos grandes conflitos como greves, por exemplo. Isso acontecia porque a empresa investia no bemestar dos funcionários e nos seu desenvolvimento. Havia um ambiente focado em atingir os objetivos comuns. A organização tinha um verdadeiro comprometimento social. Muitas obras de caridade eram realizadas anonimamente, sem fins publicitários. Essa postura da instituição contaminava positivamente os profissionais." (Profissional Experiente 7)

Em seguida, pediu-se aos entrevistados que caracterizassem um profissional competente politicamente. A intenção com essa pergunta era de verificar qual o entendimento das pessoas sobre as competências políticas, ou seja, se essa competência era vista de uma maneira positiva por sua contribuição para a solução de conflitos, disputas e para o alcance de uma boa performance. 
"Geralmente é fácil reconhecer um profissional com habilidades políticas, mas não é fácil defini-lo. As principais características que posso citar: 1) O profissional busca se relacionar não só por afinidade, mas principalmente por interesse. 2) As questões éticas e as decisões relacionadas a elas são vistas e consideradas de forma ampla. 3) Um profissional político sabe evitar conflitos inúteis ou pequenos e olha o cenário geral e os interesses individuais dos envolvidos em uma disputa." (Profissional Experiente 1)

"O profissional político pode ser visto de várias formas: a mais pejorativa é o puramente interesseiro. E tem o lado que é o exercício da negociação. Esse lado também é inerente à convivência humana, não dá para conviver coletivamente sem ser político, negociar suas ideias, seus interesses, negociar o interesse da companhia com o das pessoas. O bom político é aquele que tem uma alta capacidade de negociação, sabe ouvir, conciliar ou até quando necessário romper, ou seja, se preciso até demitir. Para o executivo ser respeitado politicamente, uma questão-chave é ter coerência de comportamento. É como uma ideologia que muitas empresas buscam instalar e criar através dos seus valores. As empresas tentam colocar isso no papel, o líder tem que conquistar isso na realidade através da sua ação e do seu comportamento." (Profissional Experiente 2)

"Quando o profissional ingressa na organização, é essencial que ele faça a leitura correta do ambiente. Ele não pode ser cooptado pela cultura organizacional. Para fazer a diferença na empresa, é preciso entender a cultura sem se deixar ser cooptado por ela. O profissional é respeitado a partir do momento em que ele entende a cultura organizacional, respeita-a, mas não é aliciado por aqueles hábitos e costumes. Quando eu entrei na organização, se eu tivesse seguido aquelas pessoas que eram avessas à mudança, eu teria sido cooptado pela cultura vigente e não teria a oportunidade de proporcionar à empresa as transformações que ela precisava. Aqueles profissionais contrários a qualquer alteração acabaram posteriormente saindo da organização. Isso é natural. Você ajuda a instituição à medida que, no ambiente político, enxerga as pessoas que não vão remar a favor da empresa. É preciso ter clareza de quem são as pessoas capazes de conduzir a organização pelas mudanças necessárias. É importante também estabelecer boas relações com seus superiores, com seus pares e com seus subordinados. Não adianta entregar ótimos resultados e ter relações ruins com a sua equipe e com seus colegas. Você precisa trabalhar para a organização em primeiro lugar. Quem entende esse papel tende a se sair bem na empresa. Esse é um papel político também. O profissional precisa lidar constantemente com esses três níveis, além do quarto, que é o mercado. A pessoa que cresce na organização é 
aquela que entrega bons resultados, que sabe dialogar e que trabalha junto com a equipe." (Profissional Experiente 9)

"Um profissional que tem a competência política, sabe formar equipe, não necessariamente uma equipe dele, mas que trabalhe para ele e o ajude a alcançar seus resultados. Se o superior convoca seus subordinados de forma autoritária, como se o servir fosse uma obrigação, o funcionário fará o mínimo; o que não é suficiente. Porém, quando o líder sabe cativar as pessoas e as faz se sentirem úteis, elas cooperam com vontade. Se o profissional tem competência política, sabe tirar o melhor dos subordinados." (Profissional 3.1)

"A primeira característica que esse profissional precisa ter é fazer uma rápida leitura de cenário. A pessoa competente politicamente entende o timing de implementação e sabe recuar se necessário. É possível perder na área política mesmo estando tecnicamente correto. Você pode se preparar antecipadamente, mas há informações que apenas o ambiente naquele momento vai lhe fornecer. A pessoa inteligente politicamente lê o cenário e reage rápido. A segunda característica, obviamente, diz respeito aos relacionamentos. Nas relações, é preciso oferecer para receber, no sentido de apoiar e patrocinar os projetos nos quais você acredita. Você faz esse patrocínio abertamente para também poder receber um patrocínio abertamente. A terceira característica é ser capaz de pertencer ao grupo. É comum um profissional não ser reconhecido como membro de um grupo. As pessoas o olham e não o enxergam como um profissional do mesmo nível intelectual ou social. Quando você cria esse senso de pertencimento ao grupo, surge a empatia e você consegue realmente atuar." (Profissional 5.1)

"Esse é um profissional que entende as relações de poder, que tem sempre como objetivo primordial ouvir antes de falar, que consegue fazer um bom diagnóstico do cenário a nossa volta $\mathrm{e}$ que tem uma legítima intenção de ajudar." (Profissional Experiente 10)

“O profissional precisa saber ouvir, não apenas escutar, mas ouvir. Integridade também é essencial. Os funcionários reconhecem a integridade do líder. Quando ele é íntegro e coerente em suas atitudes, os funcionários o respeitam. Mesmo quando há alguma discordância de opinião, o respeito continua existindo; o que não acontece quando o líder é inconsistente em suas ações. A integridade confere confiança, respeitabilidade e credibilidade ao líder." (Profissional Experiente 3) 
Em seguida serão apresentadas as características mais destacadas pelos profissionais e a associação dessas características separadamente com as quatro dimensões críticas da competência política: Astúcia social, Influência interpessoal, Network e Sinceridade evidente.

\section{- Astúcia social}

Astúcia social é a boa compreensão sobre as interações sociais e a interpretação precisa do próprio comportamento e do comportamento dos outros. Ela poder ser compreendida como a capacidade de compreender os sinais sociais e atribuir precisamente o comportamento e motivação dos outros (FERRIS et al., 2003). Os trechos a seguir corroboram essa definição:

"O gestor precisa estar muito atento aos sinais do dia a dia. Em organizações muito grandes, onde há muitas áreas entrelaçadas, é necessário ter uma boa articulação e uma capacidade de envolver outros setores em projetos comuns. Muitas vezes, você não é líder ou liderado, mas precisa construir relações com seus pares, profissionais de outros departamentos, para alcançar os objetivos comuns." (Profissional 6.2)

"Uma estratégia que eu utilizava, quando assumia um cargo mais alto, era, nos primeiros meses, não fazer nada. Eu apenas observava as situações existentes, como se eu estivesse ali decorativamente. Depois, eu fazia um julgamento pessoal dos indivíduos que estavam à minha volta, tentando estabelecer seus perfis. A partir disso, eu começava a agir. O alto executivo precisa estar atento às motivações dos profissionais que estão ao seu redor. Ele deve fazer seus subordinados trabalharem a seu favor, mas sem que se sintam obrigados ou oprimidos." (Profissional Experiente 5)

Um aspecto importante da Astúcia social é o seu precedente. Alguns entrevistados apontaram o autoconhecimento como um antecede importante para o entendimento do outro. Os profissionais com astúcia social têm um grande poder de discernimento e autoconhecimento (FERRIS et al., 2005). Pode-se verificar isso nos trechos seguintes:

"Leitura de grupo e do ambiente é muito importante. Essas relações de poder ocorrem o tempo todo e precisam ser 
percebidas. O líder que está desenvolvido e treinado consegue ter essa percepção. Eu acho que o processo mais rico é levar o líder a se perceber em primeiro lugar. Ele deve se questionar a respeito da sua própria identidade, das suas motivações, dos seus princípios éticos e das suas limitações.” (Profissional 3.1)

“O autoconhecimento é fundamental. Para ser um profissional competente politicamente, é preciso se conhecer muito bem e saber lidar consigo. $\mathrm{O}$ autoconhecimento é infinito. Nós nos surpreendemos conosco o tempo todo. Enquanto o conhecimento intelectual é limitado, o conhecimento emocional não tem limites. Quando o profissional atinge certa maturidade emocional, ele está apto a conhecer o outro e suas características. Ele consegue ouvir bem, no sentido de auscultar e de interpretar. Essas são as ferramentas necessárias ao profissional nas suas funções e nos processos de negociação." (Profissional Experiente 7)

A essência da astúcia social é a sensibilidade ao outro. Os trechos a seguir retratam essa característica:

"O grande diferencial desse profissional é conseguir analisar as pessoas que estão a sua volta. Ele sabe identificar as competências dos demais funcionários e consegue manter um canal aberto para uma conexão sempre que necessário, sem que a pessoa se sinta usada, mas sim prestigiada por estar fornecendo sua competência. Esse profissional sabe exatamente com quem pode contar e sabe como fazer esse contato." (Profissional 3.1)

"A decisão do líder depende também das pessoas que estão à sua volta. Alguns funcionários precisam muito do acobertamento, do apoio do líder. Outras pessoas são muito independentes. Eu dizia a alguns funcionários para eles se virarem e, a outros, eu explicava detalhadamente o que deveriam fazer." (Profissional Experiente 5)

"O líder precisa estar atento aos seus funcionários. Sensibilidade é outro quesito fundamental. Embora a empresa seja democrática, estimule a livre opinião e faça pesquisas de modo confidencial, existe, no Brasil, uma cultura de desconfiança e insegurança em relação às autoridades." (Profissional 3.2)

A característica mais citada pelos entrevistados para o entendimento do outro foi, sem dúvida, saber ouvir. Muitos profissionais indicaram essa como uma das características mais importantes para um profissional competente politicamente. 
"O líder precisa saber ouvir tanto elogios quanto críticas. Essa capacidade é fundamental. Se a pessoa não ouve, ela perde completamente a capacidade de perceber o ambiente que está gerenciando. Essa é uma habilidade difícil. Muitas pessoas escutam, mas poucas conseguem realmente ouvir o outro." (Profissional Experiente 3)

"É importante ouvir. Ninguém está sempre certo. As pessoas têm diferentes valores, anseios e expectativas. Essa diversidade, esse caldo, traz uma riqueza. Estar atento também é importante. É preciso observar o modo com que as pessoas o tratam e como elas se comportam." (Profissional 5.2)

"Ouvir, normalmente, é mais importante do que falar e orientar." (Profissional 6.2)

"Um profissional veio falar comigo e sugeriu um modo mais simples de aplicar o que eu queria, o que, de acordo com ele, teria uma adesão maior considerando a cultura organizacional. Estar aberto para ouvir aquele profissional foi de extrema importância. Se essa situação tivesse ocorrido alguns anos antes, talvez eu tão tivesse a maturidade de ouvir aquela pessoa e confiar nela, que entendia a cultura da organização melhor do que eu. Esse trabalho que eu iniciei mudou completamente a organização e, até hoje, essas diretrizes são seguidas." (Profissional Experiente 9)

A astúcia social se caracteriza como "sensibilidade aos outros", o que significa a capacidade de identificar-se com o outro, o que é normalmente interpretado como ingenuidade ao lidar com os outros. Para Pfeffer (1992), essa característica é, de uma forma irônica, um meio crítico para conseguir obter coisas para si mesmo por meio da identificação com o outro (PFEFFER, 1992; FERRIS et al., 2005).

"Nesse episódio eu fui até meio ingênuo, eu gostava do grupo, me associe a eles porque eu me identificava e acabei levando para o lado pessoal e me descuidei um pouco desse olhar para o outro grupo que tinha mais poder" (Profissional Experiente 2).

\section{- Influência interpessoal}

As pessoas com a habilidade de influência interpessoal possuem um estilo pessoal sutil e convincente, exercendo uma influência poderosa sobre aqueles que o cercam. As características dessa habilidade estão relacionadas à flexibilidade, ao poder 
de adaptação e capacidade de moldar o comportamento para cada situação (FERRIS et al., 2005).

"Eu tenho um funcionário da minha equipe que é tão habilidoso politicamente que ele sabe exatamente a postura que devemos adotar diante cada departamento. Ele é inalterável. Algumas vezes, ele me aconselha a agir de forma mais serena, especialmente, com aquelas pessoas com quem precisamos para trabalhar." (Profissional 5.2)

"Esse profissional deve saber como se posicionar em cada situação e como defender os interesses da organização naquele momento. Ele precisa ser capaz de calcular os impactos dos processos que ele desenvolve." (Profissional 4.1)

"A habilidade política envolve a capacidade de se colocar no lugar do outro, percebendo suas especificidades e entendendo que, para cada paciente, há um remédio. Não adianta o profissional chegar com todo o seu arsenal técnico se esses conhecimentos não são necessários naquele momento. É preciso analisar e compreender cada situação para saber a melhor forma de agir. Essa é a grande dificuldade da gestão." (Profissional Experiente 10)

"É impossível conseguir influência se você não envolve, não cria espaços, não pede opinião. Humildade, nessa hora, é fundamental. Todos têm uma experiência que os trouxe até aqui e pode ser útil. $\mathrm{O}$ que mais mobiliza as pessoas é valorizar o que elas têm para oferecer." (Profissional 3.1)

"Eu tentava analisar o conflito em razão do conflito em si. Costumava dizer que, em algumas situações, eu fingia de morto, em outras, virava general. Em certos contextos, o funcionário me expunha uma situação problemática e eu não agia, mas, em outros, eu tomava um decisão pesada. Uma vez, um alto funcionário meu veio a mim, muito exaltado, pedindo que eu interferisse em relação a outro funcionário porque ele havia tido um comportamento inadequado. Eu tentei expor ao meu funcionário que, como diretor, se eu fizesse essa interferência, provocaria uma situação ainda mais complicada. Tentei mostrar a ele que aquela briga não levaria a lugar nenhum, não traria nenhum ganho. No fim da conversa, disse a ele que fingiria não saber daquela história, pois, embora fosse minha função tomar uma atitude, aquilo não geraria nenhum benefício. Eu pedi que ele retornasse a mim se houvesse um novo problema com aquele funcionário. Ele nunca voltou. Precisamos do discernimento para saber quando e como agir. Um mesmo profissional, algumas vezes, fecha os olhos e, outras vezes, toma uma atitude severa." (Profissional Experiente 5) 
"Quando eu estava no processo de promoção para superintendente, tinha apenas três anos de empresa enquanto os demais concorrentes tinham construído suas carreiras profissionais inteiras dentro da organização. Eu precisei de habilidade para lidar com esse grupo e para conseguir me integrar. Outro aspecto importante era saber como abordar meus superiores para mostrar quem eu era e minha capacidade de trabalho. No fim, eram eles que decidiriam os selecionados. Eu precisava descobrir qual era o approach adequado para atingir cada um deles. Havia um diretor, por exemplo, com quem eu já tinha certa relação pessoal, mas eu sabia também que ele tinha outro candidato na disputa pela vaga. Portanto eu preferi não procurá-lo. O meu chefe me ajudou muito nesse processo. Ao relatar os perfis dos diretores, se eles eram mais técnicos ou mais descontraídos, ele me guiou nas entrevistas." (Profissional Experiente 4)

"Quando eu tomava alguma decisão, queria que meus funcionários discutissem comigo, se não estivessem de acordo que eles defendessem suas próprias ideias. Obviamente, para fazer isso, eu precisava conhecer o indivíduo, sua personalidade, se ele era mais calmo ou mais agressivo. Era importante também conhecer as expectativas dos profissionais, suas motivações e seu grau de satisfação.” (Profissional Experiente 5)

“O comportamento político não funciona quando o profissional não consegue cativar as pessoas e exercer sua liderança com respeito e cuidado. E, em algum momento, esse comportamento não se sustentará. Eu acho que um bom medidor da competência política é ser chamado para integrar grupos." (Profissional 2.2)

"Descobrimos que ter aliados e adeptos de suas ideias, assim como o reconhecimento de seus pares e subordinados, é importante para a ascensão empresarial. Passamos a valorizar mais a parte humana, principalmente o respeito com os demais." (Profissional 2.1)

Pfeffer (1992) apontou seis traços pessoais que, segundo o autor, são atributos relacionados com a capacidade de obter apoio e aliados. Serão citados três desses traços: sensibilidade ao outro, flexibilidade e habilidade de tolerar conflito, que foram identificados nos depoimentos dos gestores. A sensibilidade ao outro é a forma utilizada por Ferris et al. (2005) para sintetizar a essência da dimensão Astúcia Social, citada anteriormente. Já a flexibilidade e a habilidade de tolerar conflito são traços relacionados à influência interpessoal. No entanto Pfeffer (1992), ao relacionar o traço flexibilidade com a sensibilidade ao outro, amplia o seu entendimento. Para esse autor, 
não basta ser sensível aos outros se o profissional não for capaz de modificar seu comportamento. A flexibilidade permite a mudança de abordagem para acomodar os diferentes interesses. As passagens a seguir ilustram os traços de flexibilidade dentro desse contexto, mediadas por um comportamento de integridade e abertura para o outro.

"Ser político é principalmente ser flexível, dentro de um núcleo de valores e respeitando a verdade. O líder tem que ser íntegro, não um ser invertebrado que vai para um lado e para o outro. As pessoas olham a integridade do líder e se elas percebem essa integridade elas podem até discordar, mas o respeitam e confiam nele. Eu gosto de ouvir as pessoas e procuro ter menos convicções e mais ideias. Se uma pessoa me apresentar argumentos sólidos, coerentes e me convencer, não hesitarei em abandonar minhas antigas ideias. O fundador da Usiminas, Amaro Lanari Júnior, que foi vice-presidente do BDMG, tinha como lema a expressão "por que não?” Quando um funcionário dá uma sugestão, não podemos julgá-la absurda instantaneamente. Devemos sempre nos perguntar: por que não?" (Profissional Experiente 3)

"O profissional competente está disposto a ouvir seus subordinados e consegue mudar de opinião se for convencido." (Profissional 5.2)

A flexibilidade contribui ainda para a efetividade da influência por focar o objetivo principal, permitindo um afastamento emocional da situação, conforme exemplificam as falas a seguir:

"É importante lembrar que a emoção está sempre presente nos conflitos e que ela é instantânea, só perpetua se for alimentada. A maioria das pessoas não sabe disso. Uma coisa que você precisa fazer, ao trabalhar um conflito, é trazer algum tema de neutralidade para que aquela tensão não seja alimentada. Dessa forma, ela se desfaz automaticamente. No momento seguinte, o processo racional é diferente, pois não está movido pela mesma emoção. Quem conhece isso consegue interferir para minimizar o impacto da emoção negativa que produziu o antagonismo. Assim, os opositores podem fazer uma leitura racional da situação. Aquela tensão inicial se perdeu porque a emoção foi dissipada." (Profissional 3.1)

"Acredito que a melhor forma de lidar com conflitos mais intensos é interromper a discussão e se recolher na hora em que as animosidades estiverem muito alteradas. Naturalmente, as duas pessoas refletirão a respeito do conflito. Posteriormente, 
sem o estímulo da raiva, é possível voltar àquela pauta." (Profissional 6.2).

"Nas organizações, disputas acontecem o tempo todo. É preciso ter controle emocional e compreender que tudo isso faz parte do jogo. Hoje, eu entendo o que acontecia naquela época, mas, quando estava vivendo os fatos, não tinha essa percepção, apenas lidava naturalmente com aquilo. Posso dizer que eu era bom de briga porque aqueles conflitos não me estressavam." (Profissional Experiente 5)

Os trechos acima corroboram a descrição de Ferris et al. (2000) de que a competência política se baseia na capacidade de ajustar o comportamento às demandas e nuances do ambiente e de situações particulares, contribuindo, dessa forma, para um comportamento mais flexível, necessário para lidar com as dinâmicas organizacionais da atualidade (FERRIS et al., 2000).

O terceiro traço discutido é a habilidade de tolerar conflito, que é um aspecto importante da competência política que representa o respeito às pessoas, às suas posições e às diferentes visões, mesmo que antagônicas. Indivíduos com competência política estão profundamente atentos às diversidades sociais, são autoconscientes e observadores astutos (PFEFFER, 1992; FERRIS et. al, 2005).

"Toda vez que há uma divergência de opinião, surge um conflito; isso é natural. O que muda é a forma com que ele é trabalhado. Você pode lidar com o conflito tanto na base da escuta e da negociação quanto na base da discussão e do confronto verbal e físico. Isso dependerá da sua habilidade, da sua maturidade, das suas condições e da sua percepção do quão relevante e favorável aquela disputa pode ser. Sempre que há uma disputa, os envolvidos podem sair dela maiores ou menores." (Profissional Experiente 7)

"Um profissional político pode considerar posições antagônicas aceitáveis por considerar válidas ambas as premissas, sem se ater à sua posição pessoal (Profissional Experiente 1)

"Podemos perceber essa competência quando o profissional sabe lidar com opiniões divergentes." (Profissional 1.2)

"O líder tem que ter pensamento crítico. Ele não pode olhar apenas um lado; ele precisa observar várias dimensões de um mesmo problema. Ele precisa também ser um articulador. As divergências e os conflitos de interesse são constantes na resolução de problemas, na definição de rumos estratégicos e na 
tomada de decisões. É função do líder buscar zonas de convergências entre esses interesses conflitantes." (Profissional 3.2)

"Eu valorizo muito o processo da experiência. Talvez por isso eu procure sempre pessoas mais jovens, mais disruptivas e mais abertas a coisas novas. Fala-se muito, na organização, em convergência, mas eu creio que o importante é ter objetivos comuns. Precisamos ter objetivos comuns e divergir. A divergência traz o crescimento e o aprendizado. Eu gosto da divergência. Divergir em favor de objetivos comuns é muito rico. A divergência nos faz exercitar a humildade. Não existe um dono da razão. É gostoso respeitar pessoas que pensam diferentemente de nós; elas nos fazem crescer. Obviamente, existem também pessoas que divergem com objetivos diferentes daqueles da organização, mas não é a essas pessoas que me refiro." (Profissional 2.2)

"O profissional deve ser uma pessoa humilde, que não seja prepotente e que saiba dominar suas vaidades. Ele precisa ter clareza do seu papel na empresa, do seu campo de atuação, e também ter uma visão sistêmica da organização. Tento sempre criar espaços de diálogo, buscando sempre pontos de convergência. É essencial também manter a imparcialidade, dando feedbacks frequentes e apontando com clareza posturas que julgo inadequadas." (Profissional 1.1)

"A humildade é muito importante. Ter a humildade de se desculpar é fundamental em momentos de conflitos acirrados. A pessoa que é incapaz de reconhecer que errou ou exagerou em algum momento não consegue se relacionar e se reencontrar com seus colegas. O pedido de desculpa desarma as pessoas. Elas se tornam mais flexíveis e conseguem ceder mais para chegar a um consenso. Outra coisa importante é conseguir esquecer os conflitos. Depois que tudo está resolvido, é preciso superar a situação. Não podemos trazer essas discussões para o lado pessoal. Se estivermos falando em objetivos comuns, sem maldade, com valores e com ética, o máximo que pode acontecer são divergências de opinião." (Profissional 6.2)

Para exercer influência, o profissional necessariamente terá que se expor. A exposição posiciona o profissional e permite que ele ganhe adeptos às suas ideias. Alguns gestores entrevistados mencionaram a importância da exposição para aumentar o seu campo de influência, conforme relatos a seguir:

"Eu percebo também que as pessoas, normalmente, apresentam uma dificuldade incrível em expor o que realmente pensam e 
sentem. É preciso tirar as máscaras, o faz de conta. As relações devem tornar-se verdadeiramente mais humanas." (Profissional 2.2)

"É imprescindível também que a pessoa saiba se manifestar, especialmente nas reuniões. É preciso se expor, sem atropelar os outros, é claro. O profissional que se expõe de forma polida e educada tem uma vantagem sobre os demais. Humildade e educação são duas características essenciais. Eu percebo, no meu dia a dia, que aqueles diretores que são mais diplomáticos e mais polidos se destacam e têm maiores chances de ascensão." (Profissional 1.2)

"O profissional competente politicamente é uma pessoa que se posiciona nos fóruns e nas reuniões. Muitas vezes, lá na frente, as pessoas percebem que o que você havia dito se provou verdadeiro. É preciso se expor na medida correta, mas sem se autopromover explicitamente. É necessário participar com ideias que contribuam para a organização, sem falar de si próprio o tempo inteiro. Outro ponto importante é participar de grupos de discussão. Normalmente, os profissionais chamam para conversar as pessoas que eles respeitam tecnicamente e com quem têm afinidade. A formação técnica pode ser um grande diferencial nesses casos. Através desses comitês, você tem a possibilidade de se expor para diretores, vice-presidente etc. Montar bem o seu time e participar de comitês de inovação são aspectos fundamentais no ambiente político." (Profissional Experiente 4)

Segundo Ferris et al. (2005), as pessoas com influência interpessoal são dotadas de estilo de comunicação efetivo. Esse aspecto também foi descrito por profissionais entrevistados, conforme os trechos a seguir:

"As pessoas, normalmente, reconhecem profissionais com conhecimentos e habilidades acima da média. Ter uma boa oratória, conseguir se posicionar de forma clara e assertiva e saber se comunicar de maneira convincente são fatores que auxiliam no processo de legitimação. Eu acredito que a pessoa com habilidades de convencimento e mediação têm maiores chances de êxito no processo de negociação." (Profissional 4.2)

"Um aspecto importante para o profissional é a habilidade da comunicação. A pessoa competente politicamente se expõe de forma clara, se adequando a cada público. Conhecer bem seus colegas de trabalho também é fundamental. Saber um pouco dos seus históricos pode ser importante." (Profissional 4.1) 


\section{- Networking}

Os profissionais com habilidade de network conseguem identificar, desenvolver e utilizar diversos contatos e redes de relacionamento, formando alianças fortes e benéficas. Cultivam amizades, constroem alianças e coalizões. São considerados bons negociadores, sabem fazer acordos e gerenciar conflitos, não de maneira manipulativa. Acabam conquistando as pessoas com quem se relacionam e ganhando a simpatia por suas ideias, acesso a informações, cooperação e confiança (FERRIS et al., 2005).

"Para que um gerente possa implementar um projeto, por exemplo, ele precisa expor ao seu diretor os benefícios e o retorno daquilo que está sendo proposto. O diretor terá que fazer o mesmo A questão política ocorre dentro desses trâmites. Para que eu possa concretizar minhas ideias, preciso obter $\mathrm{o}$ patrocínio dos meus superiores. Para construir esse cenário político, é preciso imaginar esse conjunto de profissionais buscando apoio dos demais para executar suas propostas. Se eu consigo frequentemente apresentar ideias e medidas que são objetos de aprovação, isso gera uma repercussão. Há profissionais que não são tão brilhantes do ponto de vista da competência técnica, mas se destacam por serem desenvolvedores de equipe e por sua competência ao se relacionar e ao se comunicar. A capacidade de estabelecer redes de relacionamento tem uma influencia muito grande dentro das competências políticas. Ela pode favorecer a visibilidade do profissional e aumenta suas possibilidades de ascensão." (Profissional 4.1)

"Quando são estabelecidas conexões, zonas de influência ou networks, é fundamental manter relações sustentáveis e não simplesmente explorar o máximo daquele grupo de pessoas. Quando você mantém a integridade e a ética, essas relações tornam-se sustentáveis e, provavelmente, você poderá contar novamente com a contribuição daquele grupo em um projeto futuro. Eu creio que essa é exatamente a sabedoria de alguém competente na construção e na utilização do poder." (Profissional 3.1)

"O profissional competente politicamente precisa saber agregar e criar colaboração dentro da equipe.” (Profissional 1.1)

"É preciso ter um bom relacionamento com os seus superiores e com os pares dos seus superiores, uma boa penetração dentro da 
companhia e o respaldo dos seus subordinados." (Profissional 2.1)

"A capacidade de agregar pessoas é um ponto importante. Por melhor técnico que o profissional seja, ele não vai dar conta de cumprir todas as suas entregas sem o apoio da sua equipe. Ele precisa interagir. Esse relacionamento interpessoal é muito importante." (Profissional. 4.2)

"Eu tive a ajuda de um profissional, que já trabalhava na organização há mais tempo, e que foi muito aberto comigo ao explicar o ambiente empresarial. Ele me auxiliou na compreensão da cultura e dos ambientes políticos da organização. Esse processo foi importantíssimo para minha permanência e para minha ascensão na empresa. Isso foi uma grande vantagem. Creio que sairia rapidamente da organização se não tivesse essa orientação.” (Profissional Experiente 9)

“As pessoas vão montando seus partidos. Você precisa ter alianças muito fortes, no meu caso, principalmente, com os gerentes técnicos. Nós disputávamos a preferência dessas pessoas. O jogo político começa na promoção, escolhendo quem eu levo para o meu time, e permanece na disputa por espaço para os meus fornecedores de informação e de serviço. Para sobreviver, você precisa ter as melhores pessoas e as melhores equipes. O líder precisa cuidar dos seus subordinados." (Profissional Experiente 4)

"Quando você está almejando cargos mais altos, como superintendente e diretor, é impossível ter sucesso sem o apoio do seu superior com as dicas e informações sobre as pessoas que decidem. A excelência técnica e a entrega de resultado são o ticket para entrar no jogo. Depois, você precisa fazer essas construções de pessoas." (Profissional Experiente 4)

Muitos profissionais fizeram menção ao fato de terem sido apoiados por seus superiores, ou seja, terem bom relacionamento com pessoas importantes e influentes na organização ou se classificarem como pessoas que se relacionam bem. No entanto, no momento da caracterização do profissional competente politicamente, esse aspecto não foi tão explorado quanto se imaginou. Uma razão possível é o fato de a sociedade brasileira valorizar as relações, em que as pessoas reconhecem a importância das parcerias e amizades, de maneira que sua menção não ocorra de forma explícita e frequente, por ser um valor internalizado e institucionalizado. 


\section{- Sinceridade evidente}

Essa dimensão reflete a forma verdadeira de executar a competência política. A sinceridade evidente representa a capacidade de aparentar sinceridade, genuinidade, integridade, autenticidade. Essa dimensão da competência política focaliza a intenção percebida do comportamento em questão. A percepção das intenções e seus motivos é o que molda as respostas e reações e só será bem-sucedida se for vista como uma atitude sem objetivo obscuro (FERRIS et al., 2005). Segundo Ferris et al. (2000), a essência da competência política é a capacidade de influenciar os outros no trabalho por meio da persuasão, do suporte orquestrado, da confiança e da verdade. Questões ligadas à ética, coerência, integridade foram recorrentemente mencionadas pelos gestores, conforme se pode comprovar nas falas a seguir:

"As lideranças precisam fazer com que essas contradições, que são naturais, possam alavancar a empresa. E para que elas triunfem nesse quesito, valores como a coerência e a ética são fundamentais. Pode-se pensar que isso não importa, mas importa sim. Quando os funcionários olham para seus líderes e veem que eles têm princípios, nasce um comprometimento com a empresa; o que faz uma diferença enorme. Através das pequenas atitudes, como a relação com fornecedores, com clientes e com concorrentes, os funcionários conseguem perceber se a empresa é coerente com os valores que prega." (Profissional Experiente 3)

"A pessoa competente politicamente tem que ser muito verdadeira. Ela precisa dar feedbacks aos seus funcionários e definir com clareza as metas, sem perder de vista o bom ambiente de trabalho e o respeito." (Profissional 6.2)

"Quando uma pessoa começa a falar do familiar ou quando ela lhe revela uma fraqueza pessoal, significa que essa relação é verdadeira e deve ser desenvolvida." (Profissional Experiente 4)

"Minha experiência me mostra que ter uma atitude mais direta e transparente, no primeiro momento, pode até criar um desconforto na equipe, mas, com o tempo, as pessoas percebem que isso faz parte da função de gerir. Feedbacks frequentes e objetivos minimizam os conflitos e as disputas. Eles ajudam os profissionais a terem mais clareza sobre o ambiente de trabalho." (Profissional 2.2)

"É importante também ser visto pelos outros departamentos e pelas outras gerências como uma pessoa confiável. Esse 
profissional deve ser uma pessoa que busca mais as soluções do que os problemas e que sabe lidar com os conflitos e divergências do dia a dia. É preciso conhecer os interesses pessoais e tentar chegar a um denominador comum." (Profissional 2.1)

“O que eu sempre incentivava era a confiabilidade. Na área de vendas, onde construí grande parte da minha carreira, costumava dizer que toda pergunta do cliente precisava de uma resposta, mesmo que essa resposta fosse negativa. Isso gera confiabilidade à empresa. Quanto menor for sua capacidade de atender o cliente, mais rápido você deve dar uma resposta a ele, para que haja tempo de pensar em alternativas." (Profissional Experiente 5)

"Para o executivo ser respeitado politicamente, uma questãochave é ter coerência de comportamento. As pessoas precisam ter ideia de como o líder pensa, ele não vai agir hoje com um critério e amanhã com outro diferente. Essa coerência é uma coisa que se conquista com tempo. O líder tem que conquistar isso através da sua ação e do seu comportamento." (Profissional Experiente 2)

“É essencial que essa pessoa esteja pautada por valores éticos e motivada pelo real sentido do seu trabalho, sem priorizar resultados financeiros imediatos." (Profissional 1.1)

"Uma das coisas mais positivas desta organização é que todos os profissionais comungam dos mesmos valores. Isso é algo que me faz acreditar nos projetos. Eu sinto que posso mergulhar de cabeça, pois não há maldade nesta instituição. Nós trabalhamos em prol de objetivos comuns, buscando sempre atingi-los com a maior rapidez e eficiência. É lógico que, nesse caminho, ocorrem disputas e divergências a respeito do modo que os projetos serão executados. Inevitavelmente, algumas pessoas serão agradadas e outras serão desagradadas; mas há sempre a certeza de que os valores institucionais são maiores do que as rusgas cotidianas." (Profissional 6.2)

"Quando eu era jovem, ia ao trabalho todos os dias querendo mudar o mundo. Contudo eu percebi que é impossível mudar o mundo. $\mathrm{O}$ que devemos fazer é não permitir que o mundo nos mude. Quando estamos cercados por atitudes, comportamentos e valores escusos, é fácil sermos contaminados por eles. Podemos até nos tornar mais flexíveis, mas jamais podemos perder nossos valores." (Profissional 5.2)

Em alguns relatos, os gestores entrevistados mostraram um comportamento de coragem ou até mesmo de ousadia relacionado a assumir riscos. Alguns entrevistados 
citaram momentos em que tomaram atitudes de risco, inclusive colocando em jogo até mesmo o seu próprio emprego. Essas atitudes ocorreram em momentos em que sua credibilidade, confiabilidade, reputação e legitimidade foram colocadas em risco. A possibilidade de perder a coerência e a palavra levou esses profissionais a se comportarem dessa maneira. Eles demostraram uma conduta ética que valoriza a coerência dos seus atos atuais com suas atitudes anteriores, seus valores e discurso. Foi possível observar que esses profissionais têm uma percepção clara de que a perda de coerência e de confiança inviabiliza a sua gestão em episódios futuros, na conquista das coisas e na manutenção da sua posição e que, portanto, a única conduta exequível nessas situações é a de enfrentar superiores, correr riscos ou arriscar seus próprios empregos, a fim de manterem sua confiabilidade e legitimidade. Entende-se, portanto, que esse comportamento está relacionado à dimensão sinceridade evidente, uma vez que as atitudes de risco foram movidas pelos valores dos indivíduos, por sua conduta ética, transparente e coerente. O episódio seguinte descreve uma situação que retrata tal comportamento:

"Um episódio que vivenciei foi quando um funcionário da minha equipe foi acusado de ter dito nas conversas de corredor que na empresa as pessoas só recebiam promoção ou aumento de salário quando recebiam proposta externa. A funcionária de $\mathrm{RH}$ não conversou diretamente comigo a esse respeito $\mathrm{e}$ atravessou a conversa, reportando esse episódio diretamente ao vice-presidente no Rio de Janeiro. O vice-presidente me ligou e eu pedi a ele um tempo para conversar pessoalmente com meu funcionário, que estava viajando. Dois dias depois, conversei com ele, que negou ter dito tal frase com o argumento de que ele não era criança para dizer tal coisa. Eu fiz o que eu devia fazer, escutar as duas versões da história. Retornei ao vice- presidente e contei sobre a minha conversa. Ele então disse que era a palavra de um contra outro e que a fonte dele era de confiança e que então eu demitisse meu funcionário. Disse a ele que poderia fazer a demissão, mas que aquela decisão não era minha, na verdade, eu iria cumprir a decisão da companhia através da vicepresidência. Se eu não tomasse essa atitude, como eu me justificaria, eu não tinha motivo para demiti-lo, a não ser que eu tivesse a comprovação de que ele havia dito tal coisa. Nos termos em que eu coloquei, o vice-presidente não queria a demissão. Sugeri uma acareação dos envolvidos e meu funcionário topou. $\mathrm{O}$ vice-presidente ficou apertado, e a demissão acabou não acontecendo, então o vice-presidente, a contragosto, acabou aceitando. Isso tem a ver com o que falei de comportamento coerente. É preciso coragem de enfrentar, já era 
um profissional mais maduro, tinha mais liberdade. Se ele me mandasse embora eu me virava. Tem que ter a coerência no comportamento, eu poderia ter mandado o funcionário embora, mas como eu ia ficar com os outros?" (Profissional Experiente 2)

Um dos profissionais entrevistados, cuja experiência profissional sempre foi em ambientes extremamente competitivos, aborda a questão da confiança como primordial nesse ambiente. Esse gestor, inclusive, questiona se priorizar essa questão em detrimento de outras seria realmente um erro. Veja-se o trecho a seguir:

"Existia um profissional, por exemplo, que ficou em última colocação no ranking de resultados e comportamentos por vários anos consecutivos e nunca saiu da empresa porque tinha uma relação pessoal com o diretor. Essa amizade, obviamente, garantia informações privilegiadas. Eu não sei se isso é totalmente errado. Quando montava minha equipe, escolhia as pessoas em quem eu confiava e não, necessariamente, as mais competentes tecnicamente. Fazia isso pensando no bem da organização e no meu crescimento profissional." (Profissional Experiente 4)

É possível perceber que as quatro dimensões principais da competência política se complementam de várias maneiras, o que faz com que os seus limites, em muitos casos, não sejam muito claros. Isso ocorre porque essas dimensões são interdependentes e podem e devem ser utilizadas em conjunto para obtenção de uma maior efetividade, o que corrobora a ideia de Ferris et al. (2005) de que a competência política não é uma única habilidade ou traço. Preferencialmente reúne habilidades que se reforçam mutuamente e refletem um conjunto integrado de componentes que seja consistente, o que demonstra a complexidade dessa competência. Outro ponto importante que foi constantemente abordado pelos entrevistados se refere ao papel da coerência e ética na conduta do comportamento político. Nesse sentido é que a competência política pode ser vista pelo seu aspecto funcional, reforçando o seu caráter positivo para a efetividade das organizações e da carreira das lideranças.

Além da análise das respostas em relação às quatro dimensões, serão descritas a seguir algumas outras descobertas que foram feitas a partir de qualidades citadas pelos respondentes como características de profissionais percebidos como detentores de altos índices de competência política. Uma característica que foi identificada por muitos gestores e que não se encontra na literatura sobre o tema foi a leveza e o humor. Alguns 
gestores apontaram que os profissionais mais competentes politicamente que eles conhecem sabem utilizar a tranquilidade, a leveza e o humor para tratar de questões, muitas vezes, consideradas duras e difíceis. Esse estilo mais descontraído e leve, segundo alguns respondentes, contribui até mesmo para que os "nãos" sejam mais bem aceitos, talvez por essa leveza suavizar a negativa, deixando, portanto, transparecer uma atitude menos agressiva. Essa característica pode estar diretamente ligada aos traços culturais brasileiros de evitar conflitos. Nesse caso, o profissional não evita o conflito, mas lida com ele de maneira mais suave.

"Eu me lembro de um funcionário que era unânime na empresa. Ele chegava a todos os departamentos brincando e rindo. Isso aproxima as pessoas. Ele brincava com as situações sérias e as tornava mais leves." (Profissional Experiente 4)

"É preciso também saber dizer não de forma tranquila e sem gerar conflitos." (Profissional 5.2)

"Para descrever um profissional competente politicamente, vou usar o exemplo de um profissional que considero extremamente competente politicamente. Ele é uma pessoa que se impõe pela sua competência, ele tem uma visão muito boa do negócio. $\mathrm{O}$ mais interessante é que ele chega a todos os lugares rindo e brincando. Ele tem uma capacidade de interação invejável. Ele mantém um estado de espírito, uma alegria e uma satisfação. É um político de mão cheia. Esse profissional é um indivíduo muito preparado, tem uma personalidade muito forte e lida tranquilamente com os conflitos de interesse. Esse profissional fazia parte da minha equipe e eu queria que ele tivesse em uma posição hierarquicamente mais alta que os outros do grupo. Ele conseguiu ascender e continuar sendo amigo de todos os seus colegas. Ele enfrenta as situações com seriedade, mas, ao mesmo tempo, com uma leveza incrível." (Profissional Experiente 5)

Por outro lado, um dos profissionais entrevistados aponta justamente a dificuldade e o desafio de conseguir manter o humor e a leveza, assim como as relações mais próximas, quando se ascende na carreira e a demanda por atividades, reuniões se intensificam, tornando o tempo do profissional cada vez mais escasso, conforme depoimento a seguir:

"Queria ter mais oportunidade de brincar, quebrar o gelo e descontrair no ambiente de trabalho. Eu noto que o tempo tem 
sido cada vez mais escasso para que possamos construir um ambiente amistoso. Quanto mais você ascende na organização, menos tempo você tem para exercer as habilidades políticas. Eu não posso parar minhas atividades para ouvir meus funcionários e orientá-los com a mesma frequência com que eu o fazia antes de assumir o cargo de diretor. No entanto a experiência também nos faz captar alguns sinais mais facilmente. No nosso Comitê, conversando muito pouco, todos conseguem se entender." (Profissional 6.2)

Outro traço pessoal apontado por Pfeffer (1992) que também que foi mencionado pelos entrevistados foi o de submergir o ego e lidar bem com as pessoas. Para esse autor, existem os momentos em que é importante entrar na "briga" e outros no qual o interessante é construir alianças e redes de amizade para se dar bem com as pessoas. Nesse caso, o ego deve ser ofuscado para se alcançar um objetivo maior.

"O profissional competente politicamente é aquele que tem habilidade suficiente para se conhecer e não se perder no próprio desejo de poder. É preciso ter clareza daquilo que você pretende alcançar com o poder. Ele deve sempre tentar distinguir o que é necessário para o resultado concreto do negócio daquilo que é simplesmente ambição pessoal, desejo absoluto de sentir-se no poder. Quando gozamos do poder pelo poder, a competência se perde facilmente. Ele deve ser um instrumento para se alcançar os resultados que a organização espera de você." (Profissional 3.1)

"Eu acredito que, para ter habilidade política, é preciso ser desprovido de vaidade. Caso contrário, você morre pela sua vaidade. Se você quiser assinar todas as obras e falar que aquilo é exclusivamente seu, politicamente, você vai morrer rápido na organização.” (Profissional 5.1)

"Nós percebemos pela postura e pelo comportamento dessa pessoa que seu ego não vem para a discussão. O ego é um problema sério dentro das organizações." (Profissional experiente 10)

"Tem uma coisa em que eu falhei às vezes durante a minha carreira e que hoje eu vejo como um aprendizado. A frase "os fortes é que se submetem" revela uma sabedoria e uma humildade que me faltaram em alguns episódios e que são fundamentais. (Profissional Experiente 5)

"Quando o profissional atinge certa maturidade emocional, ele pode precisar de uma agressividade mais explícita, mas ele o fará com domínio, sem uma motivação raivosa. Às vezes, você 
precisa perder um jogo para ganhar outro lá na frente. Outras vezes, é necessário ceder. O profissional está em um estado de missão. Ele precisa ter clareza de que não está lutando por um ganho pessoal, mas por um objetivo comum da organização." (Profissional Experiente 7)

Um traço pessoal citado por Pfeffer (1992) que foi mencionado nos depoimentos dos entrevistados e que está relacionado à influência interpessoal é o de energia e resistência física, que trata da habilidade de perseverar e ser um modelo de alta energia para lidar com as difíceis e longas tarefas. O ambiente político das organizações envolve uma série de conflitos e disputas, sendo que, na maioria deles, a decisão envolve a divergência de ideias, mudança de status quo, alteração do poder dentro da organização. Esses processo podem ser difíceis e de longa duração, em razão da resistência e do embate entre os diferentes grupos de interesse. Nesse sentido, a energia pessoal é fundamental para manter a disposição durante todo o período. A fala a seguir exemplifica essa questão:

"O profissional competente politicamente precisa ter energia e motivação, especialmente no ambiente político em que as decisões são colegiadas, para puxar os temas e não deixar que as adversidades façam as pessoas desistirem dos objetivos. É preciso ter firmeza de propósito.” (Profissional 6.2)

Encontramos nos depoimentos também comportamentos relacionados a três das quatro estratégias citadas por Pffefer (1992): 1) Saber lidar com o tempo; 2) Como usar a informação e analisá-la, 3) Atitudes simbólicas.

A estratégia de saber lidar com o tempo, segundo esse autor, está relacionada à definição correta de quando agir. Isso pode ser crucial para o sucesso e implementação de uma ideia. $\mathrm{O}$ autor considera que é preciso saber quando tomar a iniciativa de agir primeiro, quando atrasar, quando determinar um prazo ou mesmo esperar ou fazer com que os outros esperem. Escolher o momento propício e considerar a ordem das proposições pode influenciar os resultados. Os trechos a seguir corroboram essa ideia:

"Tentei prolongar o processo para dar conforto para as partes, levei o tempo que eu podia levar para não prejudicar a companhia. Era um tempo de as pessoas aceitarem a decisão, conformar-se com a ideia. Era preciso distinguir o que era paixão técnica e explicar a função financeira, de lucro da empresa. A decisão foi acertada na época. Alguns profissionais 
técnicos acabaram mudando de opinião e concordaram com a decisão, ficaram convencidos, mas outros não. É preciso paciência e convencimento." (Profissional Experiente 2)

"A pessoa competente politicamente sabe a hora de se posicionar e, se for preciso, espera pelo momento adequado." (Profissional 1.2)

Já a estratégia de como usar a informação e analisá-la trata da ideia de que obter informação é fundamental, mas saber usá-la para encontrar uma resposta certa ou adequada para uma situação aumenta substancialmente o poder de influência de um profissional. O emprego de processos racionais ou aparentemente racionais de análise ajuda a tornar o uso do poder e da influência menos óbvio. Decisões são mais bem aceitas se seguem procedimentos prescritos e legitimados, conforme se pode perceber nas falas a seguir:

"Pessoas com uma inteligência matemática elevada e com uma lógica muito bem desenvolvida também se destacam. Esses dois perfis despertam a atenção e a admiração das pessoas." (Profissional 4.1)

"O profissional competente politicamente tem que conseguir atender todas as demandas. Esse profissional precisa compartilhar informações com a equipe para adquirir respaldo técnico e reconhecimento de todos a sua volta. $\mathrm{O}$ ambiente profissional requer objetividade." (Profissional 5.2)

"Você só tem capacidade de trabalho quando tem acesso a informações interessantes, ou seja, quando tem bons assessores. O profissional deve também compartilhar informações de forma sincera. No entanto você precisa escolher em quem confiar e para quem contar as coisas. As informações são preciosas. Entretanto isso não impede a boa convivência, porque tudo isso acontece de forma velada. É como um Big Brother, em que você esquece que está sendo filmado. Eu tive ótimas amizades lá na empresa. Nós competíamos, mas tudo dentro da ética, embora isso nem sempre aconteça nas organizações." (Profissional Experiente 4)

"Eu já tive que tomar decisão que não estava no meu nível de autoridade e eu tomei porque o problema chegou a mim e eu não tinha como consultar os responsáveis, mas eu decidi, eu não parava diante de um obstáculo. Esse negócio de nível de autoridade é uma bobagem. A decisão está certa em qualquer nível em que ela estiver. $O$ fato de alguém ser chefe não significa que ele está certo e seu subordinado errado. Agora, o 
funcionário precisa ter coragem e argumento para suportar suas opiniões perante seu chefe e a capacidade de assumir as consequências." (Profissional Experiente 5)

"O que me ajudou a resolver o conflito foi primordialmente ter domínio sobre o tema que eu estava trabalhando. Eu tinha estudado profundamente a questão e cruzado uma boa quantidade de dados de diferentes áreas. Eu ouvi muitas pessoas que estavam realmente passando pelo problema. A segunda habilidade necessária foi conseguir ficar calada e aguentar a reação agressiva daquele profissional. Eu esperei alguns dias para que a raiva passasse e eu pudesse conversar com ele de maneira objetiva e racional." (Profissional Experiente 7)

"Eu precisei de muita habilidade para defender a necessidade daquele recurso para minha área junto a um grupo hierarquicamente mais alto do que o meu. Isso exigiu capacidade de explanação, de contemporização e de aproximação de expectativas. Eu precisei negociar com meus líderes. Foi necessário abrir mão em alguns pontos e convencêlos a abrir mão em outros. Você sempre precisa convencer o interlocutor com fundamentos. Não pode haver imposição. $\mathrm{O}$ resultado do convencimento é melhor e mais sustentável." (Profissional 6.2)

"Em um dado momento, os resultados foram tão positivos que as pessoas que eram mais resistentes não puderam se opor. Ficou muito evidente para todos que aquela projeção que eu havia conquistado pouco importava. Talvez isso tenha sido o que mais me ajudou a desconstruir aquela postura tão resistente. O que importava eram os resultados concretos. É surpreendente perceber o que move algumas pessoas. Muitos profissionais focam apenas no que impulsiona sua projeção pessoal e se esquecem dos objetivos comuns da instituição. Isso me espanta. É impressionante como existe esse tipo de comportamento dentro das organizações, embora ele seja invisível. Às vezes, estamos travando negociações e conflitos não por um objeto em si, mas por conta dessa dimensão política que está gravitando ao nosso redor o tempo todo. É uma disputa invisível." (Profissional 4.1)

Pfeffer (1992) ressalta a importância das atitudes simbólicas, para ele as pessoas são persuadidas pela razão, mas movidas pela emoção. Os profissionais exercem influência por meio de linguagem, símbolos, cerimônias e cenários que fazem com que as pessoas se sintam bem quanto ao que eles estão fazendo. É papel do gestor fazer com que as pessoas queiram fazer o que é preciso ser feito para a prosperidade da organização. 
"O profissional precisa se preocupar verdadeiramente com as pessoas que estão a sua volta. É preciso ter certa gentileza como ligar nos aniversários ou quando o funcionário está doente. É preciso criar parcerias, chamar para almoçar, trocar ideias e conversar. Respeitar e ouvir seus subordinados são posturas essenciais. Práticas fora do ambiente de trabalho, ao ar livre, por exemplo, que promovam a união entre os funcionários são interessantes. Essas atividades trazem o lado pessoal e a parceria. $\mathrm{Na}$ vida corrida e muito competitiva, muitas vezes, você esquece que está lidando com pessoas como você." (Profissional Experiente 4)

"Embora haja os fóruns formais, a maioria das discussões acontece no corredor, durante o almoço, e nas viagens. Você precisa gradativamente ir plantado sementes para, lá na frente, $o$ projeto acontecer." (Profissional 5.1)

"Eu penso também que a questão dos ritos é muito importante. Cada pequena vitória deve ser reconhecida. É necessário valorizar o esforço daqueles funcionários que se destacaram." (Profissional 6.2)

Percebe-se no relato de alguns gestores que os conflitos e disputas pessoais que ocorrem em ambientes não públicos são mais facilmente aceito pelas partes. Essa percepção corrobora o pensamento de Mintzberg (1985), que afirma que o conflito pode não apenas ser moderado, mas também contido. Isso porque duas alianças ou dois influenciadores poderosos não têm a intenção de destruir um ao outro. Eles tentam atingir um tipo de acordo implícito, silenciando o desacordo a fim de evitar que ele se espalhe ou para garantir que a organização sobreviva. Uma possível razão para essa maior aceitação entre as partes pode estar relacionada ao fato de essas disputas não públicas deixarem clara a intenção de não destruição do seu oponente. E o intento de autopromoção ou a destruição dos demais não ocorre.

"Eu me sentava com meu primeiro chefe e exponha todas as minhas discordâncias, mas nunca levava para fora aquela situação. Era uma questão entre ele e mim apenas. Entravámos numa sala como dois homens que precisavam acertar seus ponteiros. Eu sempre fazia questão de orientá-lo e ajudá-lo. Era uma disputa com lealdade. Sempre levantei a bola do meu chefe. Nunca fiz questão de aparecer. $\mathrm{Eu}$ fazia questão era do resultado." (Profissional Experiente 5) 
"Ele não aceitou a decisão, e depois me mandou um e-mail até meio desaforado, mas mandou somente para mim, não copiou ninguém. Então eu vi que se tratava de uma paixão técnica." (Profissional Experiente 2)

As discussões acima sobre a caracterização dos profissionais competentes politicamente mostraram que essa é uma competência complexa que envolve traços, estratégias, comportamentos. As dimensões associadas a ela foram identificadas no ambiente corporativo nacional. A competência política foi reconhecida pelos profissionais como uma competência fundamental para lidar com o ambiente organizacional que é reconhecidamente político. Essa ideia corrobora o pensamento de Schriesheim et al. (2001), que sugerem que o clima político, as diferenças individuais, a reputação do líder e os índices de performance da liderança são construtos que, além de servirem como uma extensão da competência política, demonstram a natureza não linear, a dependência do tempo e a característica de multinível da teoria da competência política.

Em continuidade à análise das questões abertas, a pergunta seguinte visou verificar se os profissionais em cargo de gestão haviam recebido algum treinamento ou tinham sido expostos a situações que lhes permitissem o desenvolvimento de suas competências políticas antes de assumirem o cargo de gestão. $\mathrm{O}$ aspecto político no ambiente organizacional é normalmente tratado como algo paralelo. A expectativa era de que as empresas não possuíssem os mecanismos formais para a avaliação e o desenvolvimento das competências políticas de seus profissionais. Nenhum dos respondentes recebeu qualquer treinamento específico sobre competência política. No entanto alguns profissionais apontaram treinamentos de liderança, negociação ou processo de coaching que os ajudaram, de alguma maneira, no seu desenvolvimento de suas competências políticas. As expressões mais comumente usadas pelos respondentes para descrever a forma de aprendizado e o desenvolvimento das competências políticas pelos gestores foram: "na prática", "na vivência", "no trabalho", "no dia a dia", "de maneira intuitiva", "com a experiência", entre outras, conforme se pode verificar nos trechos a seguir:

"Não houve nenhum tipo de preparo. Desenvolvi essas habilidades na prática, na vivência. Comecei minha carreira no banco, que é uma instituição muito técnica. Lá, o critério de ascensão da carreira gerencial era a competência técnica. Se o 
funcionário era bom tecnicamente, ele, naturalmente, era promovido. Por isso, tínhamos péssimos gerentes. Às vezes, um funcionário que é excelente tecnicamente é um fiasco para gerir pessoas." (Profissional Experiente 3)

"Não. As competências políticas eu adquiri no dia a dia, convivendo com as pessoas e as observando," (Profissional 2.2)

“A rigor eu não tive treinamento. Essa questão do conflito eu sabia do meu cotidiano. Como o meu crescimento foi gradual, assumi a primeira gerência de um grupo pequeno com poucos funcionários. Então eu tinha menos responsabilidade, me expus menos no primeiro momento, aí eu fui galgando. Comecei a ser gestor aos 30 anos e quando assumi a diretoria já tinha 42 . Nesse período, fui aprendendo a lidar com essas questões de conflito. Não tive preparação, não, o próprio critério para minha escolha como gestor foi intuitivo. $\mathrm{O}$ aprendizado foi gradual e mais intuitivo." (Profissional Experiente 2)

Não. Geralmente esse treinamento é on the job. É difícil antecipar as demandas, é mais fácil trabalhar com coaching externo." (Profissional Experiente 1)

"Nem todos os profissionais apresentam essa habilidade de percepção, o que é uma pena. Os executivos deveriam ter essa formação, esse nível de conscientização. Hoje eu acredito que nem todos os executivos têm. Eu trabalhei em diversas empresas, inclusive fora do país, e não vi ninguém que tivesse preparação formal para isso. Poucas foram as situações em que isso foi colocado à mesa para discussão.” (Profissional 3.1)

"Eu fiz alguns cursos que contribuíram para isso. Quando eu me tornei gerente de contas, eu recebi um treinamento de negociação que trabalhava indiretamente com algumas dessas questões. Nós aprendíamos a preparar uma visita externa ao cliente, o que envolvia saber nos portar nesse tipo de situação, vestir-nos adequadamente etc. Contudo eu não diria que esses e outros treinamentos foram específicos para desenvolver habilidades políticas. O próprio exercício do encarreiramento e a experiência acumulada na vida profissional trazem esses ensinamentos, que são enriquecidos com insights dos cursos formais." (Profissional 6.2)

"Não. Eu fiz as formações convencionais, cursos de liderança e de cultura organizacional. Eu fui desenvolvendo essas habilidades com a minha experiência. Eu acredito que a evolução progressiva da complexidade da gestão é muito importante. Liderar uma equipe gerindo pessoas tem uma complexidade, mas gerenciar líderes de equipe tem uma complexidade ainda maior e assim por diante. Hoje, eu lidero 
líderes de líderes. Essa experiência adquirida ao longo da minha carreira me ajudou a desenvolver competências políticas." (Profissional 3.2)

"Eu não recebi nenhum treinamento.” (Profissional 5.2)

"Eu não recebi nenhum treinamento específico para isso. O trabalho de Coaching do qual participei me ajudou a desenvolver algumas dessas habilidades.” (Profissional 1.1)

"Não. Eu fiz coisas que eu não sei quem me ensinou. Bem mais tarde na minha carreira, fiz um trabalho de coaching que me ajudou muito. Durante esse processo, percebi algumas características minhas, como humildade, confiabilidade, perseverança - eu não parava diante de um obstáculo -, capacidade de correr risco calculável, ou seja, risco que você pode suportar e discernimento, que me ajudaram a vencer." (Profissional Experiente 5)

Foi possível perceber que existe uma consciência da importância dessa competência, mas que as organizações não possuem práticas para identificar o perfil e as necessidades dos profissionais nesse quesito, ou mesmo não oferecem treinamentos a respeito do tema ou não proporcionam a exposição desses profissionais a situações que os preparem para a atuação na "arena política". Uma das razões possíveis para essa lacuna pode estar relacionada ao fato de o assunto não ser explicitado, ou seja, ser tratado ainda como um tabu. Acredita-se que, ao trazer a perspectiva positiva desse comportamento e a explicitação do aspecto político positivo, aumentarão o interesse e a conscientização sobre o desenvolvimento dos profissionais nessa competência. Os depoimentos a seguir retratam essa reflexão:

"Nós temos uma universidade corporativa que é absolutamente extraordinária, mas, em nenhum curso, trabalhamos essa dimensão. É como se ela não existisse. Essa dimensão é tão absurda que tratar disso em um curso seria reconhecer sua existência. É surreal não trabalharmos essa dimensão, mesmo ela sendo tão comum e tão presente." (Profissional 4.2)

"Os aspectos político e relacional são muito importantes, e poucas organizações dão a devida atenção a eles. Se essas questões fossem trabalhadas logo na primeira transição, o funcionário teria maiores chances de êxito na sua ascensão profissional." (Profissional Experiente 10) 
Fica claro que os profissionais entrevistados desenvolveram sua competência política de forma intuitiva, no seu dia a dia, provavelmente por apresentarem uma propensão natural que os levaram a uma percepção dos aspectos políticos das interações sociais na organização. No entanto Ferris et al. (2005) alegam que a competência política pode ser treinada, mesmo que uma pessoa não tenha uma propensão natural para isso. Os autores afirmam ainda que não importa quão habilidosa seja a pessoa, se ela nunca trabalhar sua competência política ou ficar exposta a uma situação que revele essa habilidade, ela não irá se desenvolver ou acontecer.

Quando os gestores foram indagados se levavam em consideração além dos aspectos técnicos a competência social e a sabedoria política para promoção e seleção de profissionais para a sua equipe, todos disseram considerar esse um aspecto importante na contratação e promoção dos profissionais:

"Muito. É um pouco intuitivo, um pouco de leitura. Eu compreendi que o exercício da liderança passa pelo exercício de conviver, criar um ambiente harmônico, dirimir conflitos. É mais fácil ter um subordinado com essas características, senão lhe dá mais trabalho, você tem que cuidar dele e dos funcionários dele. Até para tornar o meu trabalho mais fácil. Sempre valorizei um bom ambiente. Para mim isso é fator-chave para as empresas, sempre pesou muito. É preciso que o profissional tenha essa habilidade para criar um clima agradável e para resolver as questões conflituosas." (Profissional Experiente 2)

"Sim. Principalmente no banco, onde trabalhei quase 20 anos, tive a percepção de que a capacidade técnica era só uma parte das habilidades necessárias. Isso ficou muito claro depois de certo tempo. Então, procurávamos profissionais que entendessem o conjunto, que fossem bons líderes e que soubessem ouvir." (Profissional Experiente 3)

"Não adianta nada o líder ser legitimado por um processo seletivo claro e transparente, mas não conseguir exercer bem a sua função. Nós não podemos ser ingênuos em relação aos processos de seleção profissional. Os critérios formais são importantes, mas são limitados. O que vai conferir legitimidade é a sua capacidade de trazer crescimento para os funcionários e de fazer as mudanças de que a área precisa. Quando eu faço entrevistas de seleção, considero muito as competências políticas. Eu busco explorar, nessas situações, essa outra dimensão que não é avaliada no processo seletivo." (Profissional 2.2) 
"Eu sempre levei esses fatores em consideração. Primeiramente, porque são coisas em que eu acredito. Esses profissionais tornam mais fácil a resolução de problemas e de conflitos." (Profissional 1.2)

"Com certeza, só entra no meu time quem tem bons relacionamentos políticos, quem tem jogo de cintura. Sei que, mesmo se eu não estiver em uma reunião, meu time dará conta. Os aspectos político e relacional são, muitas vezes, mais importantes do que o aspecto técnico. A técnica nós aprendemos juntos e desenvolvemos naturalmente ao longo do tempo." (Profissional 5.1)

"Devido à minha longa experiência como gestor de equipes, desde líder de pessoas até líder de líderes, eu valorizo muito as dimensões relacionais e a habilidade de administrar conflitos. A organização fornece aos gestores mecanismos objetivos e estatísticos para selecionar os profissionais mais competentes tecnicamente. Esses instrumentos consideram a formação, a experiência e a entrega de resultados. Portanto eu não preciso me preocupar tanto com a técnica, pois esses quesitos já são automaticamente avaliados. Nas entrevistas, eu prefiro me aprofundar nas questões políticas." (Profissional 3.2)

"Os aspectos político e relacional são essenciais. Embora eu não seja bom em julgar esses quesitos, sempre soube que eram importantes. Eu costumava dizer aos meus funcionários do setor de vendas que o que vale em uma relação comercial é a relação." (Profissional Experiente 5)

"Se existem dois funcionários com o mesmo conhecimento técnico, mas um bate de frente e outro contorna os problemas, é lógico que o segundo é mais bem sucedido. A pessoa mais flexível e mais calma traz serenidade nas situações difíceis. A questão política é essencial. Se você escolhe pessoas pouco colaborativas, terá problemas no seu dia a dia." (Profissional 5.2)

"Sim. Esse aspecto é fundamental. Quando você promove um funcionário antipático, por exemplo, ninguém quer trabalhar com ele, mesmo que ele tenha um desempenho fantástico. Ele pode atingir ótimos resultados, mas mata a equipe. Ele não desenvolve e não promove seus funcionários. O profissional tem que gostar de promover." (Profissional Experiente 4)

"Durante toda a avaliação, eram analisados aspectos relacionais e políticos. Desde a forma como o candidato escrevia o currículo até suas relações e o seu comportamento nas entrevistas e nos testes, podíamos traçar o perfil, o estilo essencial dessa pessoa. É importante ressaltar que uma pessoa pode se adaptar a uma 
instituição e não se adequar a outra. As pessoas e as organizações apresentam suas singularidades. A decisão de contratar ou não envolvia todos os gestores. Eles discutiam até chegar a um consenso. A participação dos gestores era uma forma de sustentar a contratação e de comprometê-los a auxiliar esse novo funcionário. Os gestores eram corresponsáveis pelo processo." (Profissional Experiente 7)

. "Sim, na medida em que a habilidade de relacionamento especialmente numa função ambígua como a Gestão de RH vai se tornando cada vez mais importante para a área atingir seus objetivos." (Profissional Experiente 1)

Solicitou-se aos entrevistados que identificassem uma situação em que precisaram de competência política para resolver um conflito ou uma disputa, mencionando o processo detalhadamente, ou seja, explicando a situação, o que antecedeu o problema, como se deu sua resolução e qual havia sido o resultado final. $\mathrm{O}$ plano com essa pergunta era de buscar compreender todo o processo, ou seja, como a competência política é utilizada para alcançar a solução de um problema, considerando o processo no seu início, meio e fim. Elaborou-se um quadro contendo alguns exemplos citados com as informações mais relevantes dos casos para facilitar a visualização do processo (QUADRO 4). 


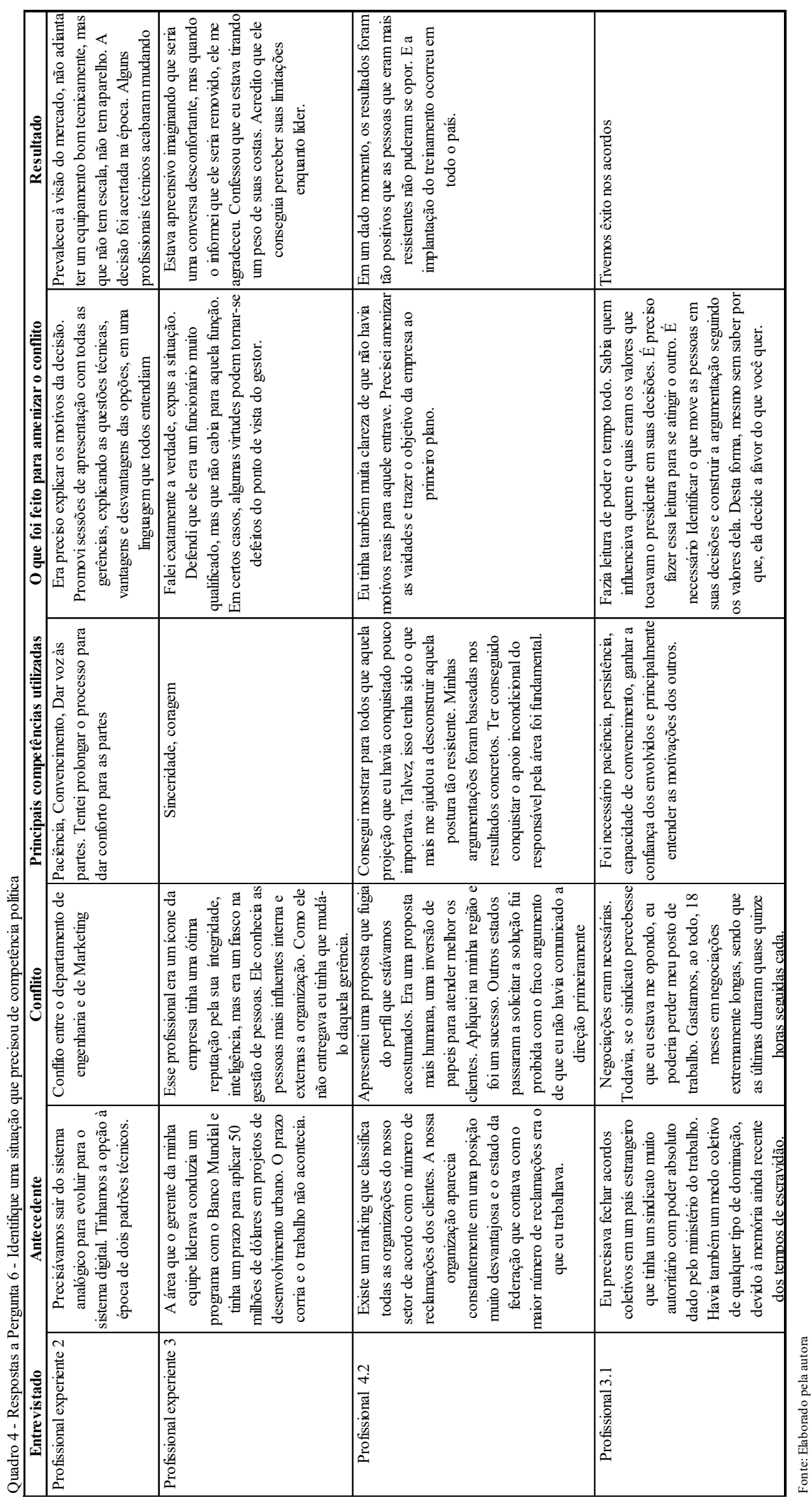


Perguntou-se também aos empregados das empresas como os conflitos muito acirrados são resolvidos na empresa. A finalidade dessa pergunta era descobrir o que acontece quando pessoas de grande influência na empresa entram em disputas entre si, ou seja, qual é o critério de arbitragem, quem sai ganhando e se há algum sinal de mudança no sistema de influência, por exemplo, a substituição de um sistema de influência político por um sistema de influência de autoridade. Os resultados encontrados foram descritos nas passagens seguintes:

"Eu vivi isso e acabei pedindo demissão. O presidente da empresa deixou a organização. Eram dois grupos grandes que comandavam a empresa. Fui indicado por um dos grupos para me candidatar a assumir a presidência. $\mathrm{O}$ outro grupo indicou outra pessoa. Havia uma desavença crescente entre esses sócios. Eles se reuniram para discutir sobre o tema, não chegaram a um acordo e o meu nome foi vetado pelo segundo grupo. Quando vi na ata da reunião que esse segundo grupo que estava prevalecendo me negou a progressão, eu me demiti. Achei que a melhor decisão era pedir minha demissão, não me senti com moral para comandar a equipe sem ter a confiança do grupo controlador. Esse conflito tem que ser resolvido rápido, não é uma questão técnica, não exige o convencimento. Caso contrário você instala um clima de competição, um problema de alinhamento, fulano mais identificado com outro se alinha aqui, o outro se alinha ali e você divide a companhia." (Profissional Experiente 2)

"Na última empresa em que eu trabalhei, houve um caso de conflito acirrado e o critério de arbitragem foi o objetivo da empresa. Havia dois funcionários, ambos competentes, mas com concepções conflitantes. O embate se acirrou e se tornou um problema pessoal. Então, nesse caso, nós tivemos que demitir. Precisávamos escolher um deles, e o critério utilizado foi manter aquele cujas características se adequassem mais aos objetivos da organização como um todo. Selecionamos o funcionário que, em nossa visão, tinha um melhor conceito de empresa." (Profissional Experiente 3)

"Os conflitos fazem parte do nosso cotidiano porque estamos negociando recursos escassos o tempo todo. Eles podem aparecer travestidos dos interesses da organização. Na maioria das vezes, isso não se decide no âmbito daqueles dois departamentos. Uma instância superior arbitrará, definindo qual daquelas duas propostas é a mais prioritária naquele momento. Dificilmente, haverá uma mediação entre as partes para se chegar a um denominador comum." (Profissional 4.2) 
"Os conflitos, às vezes, complicam-se e começam a afetar valores. Nesses casos, não pode haver flexibilidade. Se for preciso sair da organização, é isso o que deve ser feito." (Profissional 5.2)

"Nesses casos, o nível mais alto precisa interceder. Normalmente, ocorre essa mediação e é criada uma nova situação para ser discutida. Não adianta levar o conflito ao limite. Em conflitos muito acirrados, em que as partes não estão se entendendo, é preciso mediar o problema e, posteriormente, criar outro ambiente de discussão. É necessário entender o conflito e mexer nas peças do xadrez. Às vezes, trocar algumas pessoas, para a próxima discussão, pode amenizar bastante o conflito. Você precisa saber o momento de cessar, caso contrário, põe muito a perder. Só por estar no meio daquela discussão, você perde a reputação que construiu. Em algum momento, você será requisitado para dar sua opinião e, então, terá que dá-la." (Profissional 5.1)

"Uma característica política interessante é justamente não ter enfrentamentos. A organização em que eu trabalhava estava passando por um momento de grande conflito. Era uma disputa que envolvia dois profissionais, dos quais um seria o próximo presidente da organização. Esse conflito impactou todos os funcionários. Havia pessoas que sabiam que, se um desses dois profissionais entrasse, elas seriam demitidas. Quanto mais alto você sobe, mais você precisa aprofundar suas escolhas e fazer opções. Um dos meus chefes, por exemplo, era excelente tecnicamente, foi promovido, e o grupo não o aceitou. Nessas disputas acirradas, alguém sai. Normalmente, fica aquele cujas ideias são mais coerentes com a realidade atual e com as expectativas para o futuro. Fica aquele que está mais alinhado com o que vai acontecer.” (Profissional Experiente 4)

"Eu tive a sorte de trabalhar um uma organização muito ética e com profissionais muito qualificados. O presidente da empresa era uma pessoa muito sábia que eu admiro imensamente. Quando ele queria falar algo a alguém em uma reunião, ele o dizia a outra pessoa. No início, eu ficava perdida, mas depois entendi sua intenção. Isso desviava o foco dos membros da reunião da pessoa a quem o presidente estava realmente se referindo, fazendo com que ela pudesse refletir e não sofresse o julgamento dos demais. Os conflitos graves eram tratados individualmente. O presidente era extremamente cuidadoso com as pessoas." (Profissional Experiente 7)

Os depoimentos mostraram que os casos de conflitos muito acirrados entre departamentos importantes ou pessoas influentes na organização, na maioria dos casos, passam a ser tratados por uma instância superior e, nesses casos, o sistema de influência 
de autoridade predomina. Nos depoimentos dos gestores, foi possível observar que é comum a saída da organização de um dos profissionais envolvidos na disputa, sendo que o critério de arbitragem costuma ser o alinhamento aos objetivos da empresa ou do grupo de poder. Fica claro que é comum o movimento político dos profissionais na formação de grupos pelo alinhamento de ideias, interesses, crenças, estratégias, valores etc. As disputas acirradas, de modo geral, foram vistas como negativas em razão de afetar o clima organizacional e de instalar um clima de competição entre os grupos, prejudicando o andamento das atividades e dos projetos da empresa.

Além da aplicação do questionário (PSI) para autoavaliação quanto à competência política, incluiu-se uma questão aberta, a fim de verificar se os profissionais entrevistados se consideravam competentes politicamente e qual a percepção deles se essa competência contribuiu ou fez falta em algum momento para o desenvolvimento das suas carreiras. A finalidade dessa pergunta era verificar se os gestores veem a competência política como uma competência importante para o sucesso das suas carreiras. Os trechos a seguir revelam algumas das respostas dos executivos a essa pergunta:

"Eu creio que sim, pela minha trajetória. Comecei na empresa como operário e me tornei diretor executivo internacional do grupo. Sem competência política isso seria impossível. Eu fui desenvolvendo essa habilidade, é ruim falar assim de si mesmo, mas eu sempre me destaquei por isso. Eu tinha o respeito de todos os operários. Era muito bem visto em geral. Todos me ouviam e aceitavam o que eu dizia. $\mathrm{Eu}$ ascendi profissionalmente devido ao apoio da massa. Eu sobressaí porque tinha conhecimento dos valores que moviam os empregados. Isso me ajudou muito." (Profissional 3.1)

"Eu me considero um profissional competente politicamente. Eu me dou bem com meus pares, com meus superiores e com meus funcionários. Consigo resolver os problemas cotidianos de forma ágil e tranquila. Transito bem em todas as áreas e em todas as equipes. Eu faço questão de cumprimentar todos os funcionários e de estar sempre presente. Procuro tratar todos da mesma forma." (Profissional 1.2)

"Acredito que sou uma pessoa muito competente politicamente e isso me ajudou. Se você estiver atento às coisas que as pessoas naturalmente ensinam, é possível desenvolver as habilidades políticas. As pessoas nos ensinam como agir e como não agir." (Profissional 5.2) 
"Pela minha autoavaliação e pelos feedbacks que recebo, eu acredito que tenho um nível de habilidade política adequado para a função que desempenho. Gosto de colocar dessa forma porque eu ainda tenho muita competência a ser desenvolvida. Eu me sentia muito mais preparado, no meu último cargo de Gerente Regional, do que eu me sinto hoje, como executivo. Eu precisei dessas bases para desenvolver o nível de competência que detenho atualmente. Nas minhas novas funções, especialmente este ano, as competências políticas me ajudaram. É preciso ter muita delicadeza para administrar conflitos para que eles não se expandam.” (Profissional 3.2).

"Eu acho que sim. A competência política é decisiva não apenas dentro da organização, mas na vida de forma geral. Eu busco ser uma profissional colaborativa. Tento desenvolver boas relações com meus subordinados, com meus pares e com meus líderes. Outra coisa importante, que me esforço para realizar, é criar agendas comuns, fazendo com que meu departamento esteja integrado ao máximo com os demais setores da organização." (Profissional 1.1).

"Eu sou altamente competente politicamente e cheguei onde cheguei por causa disso.” (Profissional Experiente 5)

"Eu me considero um profissional competente politicamente. Saber me relacionar foi fundamental para minha rápida ascensão na organização. Minha facilidade em ser aceito em grupos e minha flexibilidade me ajudaram muito. Eu tenho a habilidade de não ser notado, se eu não quiser." (Profissional Experiente 4)

"Eu acredito que umas das minhas vantagens profissionais é a competência política. Eu não imponho minha opinião pela autoridade, busco sempre conciliar as expectativas e opiniões da minha equipe. Tento orientar meus liderados em busca dos melhores resultados. Eu estabeleço boas relações com os demais profissionais o que auxilia no processo de articulação." (Profissional 6.2)

"Eu creio que sim. Para me tornar diretora em um ambiente majoritariamente masculino, foi preciso ter muita competência política. Precisei desenvolver essas competências para trabalhar em um ambiente tão hostil. Hoje, o cenário é bastante diferente. Muitas mulheres conseguem construir uma carreira de sucesso na empresa. Eu cheguei a ouvir que, apesar de ser mulher, desempenhava meu papel muito bem." (Profissional Experiente 7)

"Eu acredito que ninguém sobrevive em uma empresa, do ponto de vista de carreira, se não tiver essa competência. Entretanto o profissional precisa tomar certos cuidados. Se ele usa essa 
competência política apenas em favor da sua carreira, quem perde é a empresa." (Profissional 2.2)

Outra pergunta tratou sobre as diferentes percepções possiveis do comportamento político em razão da intenção dos seus atores. Os gestores foram solicitados a exemplificar comportamentos que poderiam ser considerados disfuncionais ou funcionais. A razão para essa pergunta foi a avaliação do comportamento político como um conceito neutro, ou seja, buscou-se verificar se os gestores percebiam esse comportamento de diferentes formas, tanto como positivo quanto negativo, dependendo da intenção e dos resultados da ação dos seus atores. Caso os entrevistados fossem capazes de exemplificar comportamentos das duas naturezas, essa informação poderia apoiar a ideia da neutralidade do termo. A seguir, apresentam-se algumas das respostas dadas:

"A questão de ver a dimensão política como positiva ou negativa tem a ver com os valores e os recursos que o indivíduo tem, além do que está em jogo. Geralmente vemos a política de um modo negativo quando os resultados são, da nossa perspectiva, socialmente injustos ou pessoalmente injustos. (Profissional Experiente 1)

Nos trechos seguintes, destacam-se os comportamentos políticos que foram identificados como disfuncionais:

“A política disfuncional é quando as atitudes do profissional visam o crescimento pessoal, o interesse pessoal em prejuízo do interesse coletivo, institucional. Isso não leva a nada, gera gastos e aumenta a divisão entre os grupos da empresa. Isso existe muito sim, mas, na maioria das vezes, isso é visto. As pessoas não conseguem dissimular facilmente. As pessoas sabem ler. Elas conseguem perceber essa intenção e criticam no cafezinho." (Profissional Experiente 2)

"É comum se atribuir uma conotação negativa ao termo "político". Talvez pela visão muito negativa que existe do político, associa-se esse termo a pessoas cínicas, incoerentes. Não há coisa pior no ambiente político da corporação do que a mentira. Ela é um veneno.” (Profissional Experiente 3)

"Esse comportamento torna-se negativo quando a pessoa se esquece dos objetivos comuns, dos valores éticos e passa a agir apenas por interesse próprio.” (Profissional 1.1) 
"Quando há uma situação de impasse e as pessoas não querem abrir mão de sua opinião, os projetos são atravancados e a organização é prejudicada. Esse tipo de comportamento é disfuncional. As pessoas não conseguem ceder e negociar com seus pares. Felizmente, eu percebo que o comportamento funcional está mais presente." (Profissional 1.2)

"Esse comportamento é disfuncional quando ele é apenas político, quando um profissional cria intrigas ou age de forma ardilosa. Desse modo, o bem comum e os interesses da companhia são relegados a segundo plano pelas ambições pessoais. O profissional deixa de se expor, de se colocar em risco e passa a agir politicamente com o intuito único de crescer na empresa." (Profissional 2.1)

“O uso disfuncional do comportamento político ocorre quando a pessoa se perde no gozo do poder. Quando uma pessoa manipula, explora outra, esta desconfiará mais cedo ou mais tarde. Assim, a conexão se perde, pois não é sustentável. As pessoas são como crianças. Podem não perceber com clareza que estão sendo usadas, mas sentem um incômodo e não querem mais contribuir. Esse desconforto se dissemina entre os funcionários e a percepção aparece. Os princípios éticos sendo feridos, não há sustentabilidade, e a pessoa se perde." (Profissional 3.1)

"Muitas pessoas entendem o comportamento político como aquele que não é transparente, que é invertebrado para se adequar a todos os grupos. Esse comportamento político é o disfuncional. Ele é típico daquela pessoa que faz de tudo, inclusive muda de opinião, para ficar bem com seus superiores. Esse comportamento é político porque tem o objetivo de se posicionar favoravelmente nos grupos. Entretanto ele é disfuncional, pois não trabalha no campo da verdade. $O$ comportamento político disfuncional é egoísta. O funcionário pensa somente em si e se esquece do coletivo." (Profissional 3.2)

"Acontecem também comportamentos disfuncionais que buscam a autopromoção, como a utilização de ideias alheias. Contudo aquilo que não tem fundamento e solidez não se sustenta e, uma hora ou outra, vai ruir. O nível e ritmo de entrega são muito altos. Se o profissional não tem competência, ele não consegue manter o desempenho. O próprio meio o expele. Quando você percebe, a pessoa não faz mais parte daquilo.” (Profissional 6.2)

"Conheço um profissional que considero ter um comportamento político disfuncional. Ele é competente tecnicamente, mas, em situações de conflito, ele extrapola e perde a razão. Talvez não 
haja um intuito negativo, mas uma incapacidade de lidar com o problema." (Profissional 5.2)

Foi possível perceber que o comportamento político disfuncional acontece e é identificado pelos gestores. $O$ pensamento mais comum foi de que esse comportamento é bastante prejudicial para os resultados da organização e também para as relações interpessoais, visto que seus atores focam exclusivamente no benefício próprio. $\mathrm{Na}$ maioria das vezes, esse comportamento é percebido e criticado, em alguns casos essa percepção pode demorar um pouco, mas as pessoas acabam percebendo, ou seja, ele não se perpetua. Esses achados corroboram o pensamento de Mintzberg (1985) de que não é necessário dedicar espaço aos aspectos disfuncionais da política nas organizações, afinal de contas ela é divisionista, cara e gasta a energia que deveria ser usada para alcançar a missão da empresa.

Em seguida apresentam-se as falas que mostram os comportamentos políticos que foram classificados como funcionais pelos entrevistados:

"O comportamento político que eu considero funcional é aquele em que a pessoa tem liberdade e condições de colocar o que pensa verdadeiramente sem desrespeitar as posições antagônicas, buscando uma posição consensual. $\mathrm{O}$ posicionamento político funcional ocorre quando há transparência e ética na busca dos interesses da equipe e da organização." (Profissional 3.2)

"Eu percebo atualmente que, quando você tende a não dar a sua opinião em uma discussão, você está sendo disfuncional porque não contribui para o debate de forma efetiva e não fornece seu conhecimento para ajudar a organização. Você é funcional quando sabe escutar, mas se coloca. Isso não significa que sua opinião deve prevalecer. É preciso apoiar a decisão final da equipe, mesmo que aquela não seja sua opinião. Baixa competência nós treinamos. Bons profissionais nós reconhecemos. E profissionais antiéticos nós não toleramos."(Profissional Experiente 10)

"Ser político, na minha visão, é ter princípios e critérios, é respeitar as diretrizes e as estratégias da organização, que são nossos grandes árbitros." (Profissional Experiente 3)

“O comportamento funcional ocorre quando a política é apenas um instrumento para saber lidar melhor com as pessoas e para ter uma melhor penetração na organização." (Profissional 2.1) 
"O comportamento político funcional ocorre quando as pessoas conseguem lidar com opiniões, comportamentos e valores diversos." (Profissional 5.2)

"O comportamento político é funcional quando gera complementaridade, ampliando as discussões e proporcionando novos conhecimentos. O comportamento político utilizado como instrumento para buscar soluções e para se atingir metas comuns é positivo." (Profissional 1.1)

"O comportamento político funcional baseia-se em uma habilidade de articulação, de negociação, de construção de propósitos, sempre com ética. Existem profissionais que têm a habilidade de convencer pessoas bem intencionadas a integrar projetos que vão ao encontro dos propósitos da organização." (Profissional 6.2)

"A política funcional depende da coerência comportamental, proximidade com a equipe, gestão clara e muita cobrança também." (Profissional Experiente 2)

Em continuidade ao aspecto funcional e disfuncional do comportamento político, os entrevistados foram indagados sobre a melhor maneira de incentivar o comportamento político funcional e de inibir o comportamento político disfuncional. A intenção dessa pergunta foi verificar se, além da percepção do aspecto funcional e disfuncional, os gestores têm uma ideia clara de como tratar cada caso, ou seja, como lidar com as diferentes situações. A seguir, apresentam-se as respostas dadas pelos gestores:

"Então, isso deve ser posto pela liderança e pela organização um conjunto de valores e crenças que leve a cultura da organização a comportamentos construtivos." (Profissional Experiente 1)

"Essa questão é influenciada pela cultura da empresa. Já trabalhei em empresa com raiz estatal, onde o valor da convivência era importante, mais paternalista, onde o erro era mais tolerado e também em empresa onde se estimulava a concorrência interna. No fundo, o que a empresa queria com a competição extrema era fazer com que as pessoas produzissem muito. Para mim, não é preciso criar um clima de competição (guerra) para conseguir o aumento da produtividade. Eu encontrei outros mecanismos para aumentar a produção. Você tem também a influência do líder. Eu como líder e com a minha equipe trabalhávamos num clima mais harmônico. Trabalhava de maneira informal no tratamento com as pessoas $\mathrm{e}$ 
extremamente formal em relação aos indicadores e às cobranças. A minha equipe era uma equipe de alta produtividade." (Profissional Experiente 2)

"As ambições individuais devem sempre estar subordinadas ao interesse coletivo da organização. Esse é um princípio básico. Funcionários que pensam somente em seus próprios interesses são destrutivos. Eles não cooperam, pelo contrário, querem prejudicar o colega, pois o veem como um concorrente. Essa é uma visão obsessiva e paranoica de ambição. $\mathrm{O}$ grande dilema das empresas, e até da sociedade, do ponto da organização é gerenciar a cooperação e a competição. As lideranças precisam equilibrar essas forças aparentemente contraditoras, mas que são saudáveis no funcionamento da empresa. Se a cooperação é atrofiada e a competitividade estimulada, criam-se funcionários destrutivos. Esse quesito é especialmente importante hoje, em que a maior parte dos processos das empresas é feita por equipes multidisciplinares. A pessoa muito competitiva acaba sendo expelida. Eu via casos na empresa em que, na hora de escolher gerentes para promoção, ninguém queria aqueles extremamente competitivos. Eles podiam até ser competentes, mas eram egoístas. Os profissionais escolhidos eram, normalmente, gerentes mais cooperativos; o que não significa que eles não tinham ambição." (Profissional Experiente 3)

"O ideal seria eliminar o disfuncional. Acredito que esse comportamento não agrega nada. Obviamente, cabe também certa instrução por parte dos superiores, principalmente quando se sabe que o profissional é uma boa pessoa e que essa atitude pode ser alterada. Às vezes, as pessoas agem desse modo como uma forma de proteção, por medo ou até por experiências pessoais e familiares. Para incentivar o comportamento funcional, eu acredito que se deve manter um ambiente de solução, tentando sempre buscar respostas e não mais problemas. É preciso focar nos objetivos gerais da organização, mesmo que isso não o coloque na melhor posição possível. Quando você atinge seu objetivo, o reconhecimento, mais cedo ou mais tarde, virá, mesmo que os louros sejam de outros. É muito comum no meu meio você ser o responsável por todo desenvolvimento de um projeto e outra pessoa ser congratulada por ter tido a ideia inicial. Entretanto a empresa sabe que você é o maior responsável. Lidar com essas questões, de certa forma, faz parte do seu amadurecimento. É preciso saber lidar com isso." (Profissional 2.1)

"Uma estratégia concreta para inibir o comportamento disfuncional é produzir cumplicidade. Quando as pessoas não são autores, tornam-se críticos. E isso é automaticamente uma forma de poder. Descobrir como as pessoas podem contribuir e pedir aquela contribuição. Todos estão ávidos para participar. Não participar é estar refém, sofrer as consequências daquilo 
que foi produzido por outrem. Se você não participa, não sabe como será impactado pelas decisões. Dessa forma, entra-se no espaço do medo, que gera a insegurança. Toda vez que isso acontece, cria-se o fato estimulador que produz a resistência. Nesse caso, a oposição se dá pelo desconhecimento do que está sendo proposto. Esse é um princípio que eu utilizo, especialmente para treinar minha equipe. $O$ poder de influência aumenta, pois você inibe as pessoas de criticarem a obra da qual participam. Elas podem até criticar, mas o tom será diferente. As pessoas se sentem parte daquilo, defendem aquilo." (Profissional $3.1)$

“A empresa precisa estabelecer seus valores. Ética, transparência, respeito à opinião contrária e à diversidade são princípios essenciais que devem ser explicitados. Dessa forma, a organização consolida o comportamento político funcional. A empresa que desenvolve pouco a consciência das pessoas é uma empresa cheia de controles. Ela precisa do controle externo porque as pessoas não têm autocontrole. Organizações que têm um bom desenvolvimento ético não precisam controlar tanto seus funcionários. $\mathrm{O}$ viés do sucesso em organizações capitalistas é o resultado. O resultado é a pá de cal de muita coisa. Algumas vezes, contudo, ele pode distorcer a situação. A empresa que é coerente com seu código de ética e permite que seus funcionários se expressem consegue blindar minimamente o comportamento do tipo disfuncional. Um gestor que coloca os resultados acima de tudo e de todos, mas que tenha um comportamento aparentemente ético, pode até ser promovido na empresa. Contudo, uma hora ou outra, esse comportamento aparece." (Profissional 3.2)

“A cultura empresarial é a melhor forma. Nós tentamos fazer uma gestão da cultura na organização. Nosso estudo mostra que só é possível fazer a gestão da cultura se a cultura andar junto com a estratégia. Se nós dizemos que a ética é um valor da instituição e queremos que os funcionários sejam éticos em suas atitudes, a cultura precisa estar alinhada à estratégia. Em todos os treinamentos da empresa, nos documentos estratégicos e nas declarações da visão e da missão, a ética deve ser um conteúdo primordial. Quanto mais você pratica a ética e fala sobre ela, mais as pessoas internalizam esse valor. Para inibir o comportamento disfuncional, é preciso haver exemplo e disciplina. Nós temos um departamento voltado para avaliar e punir desvios éticos. Quando a questão é muito séria, é preciso demitir. Quando são coisas menos graves, como inveja e ciúmes, um feedback ou um aconselhamento podem resolver a questão." (Profissional 6.2)

"Eu acredito que o exemplo é a forma mais eficaz. Quando os líderes são coerentes e honestos, há uma maior probabilidade de 
os funcionários também o serem. A cultura da empresa e seu código de ética também são importantes." (Profissional 1.1)

"Quando a situação torna-se insustentável, é preciso demitir o profissional com o comportamento disfuncional." (Profissional Experiente 4)

“O exemplo é a melhor forma. Não adianta ter um discurso incentivando o comportamento positivo, mas ter práticas que o contradizem. Os valores da organização, do presidente e do fundador são essenciais. Os setores da organização zelam pelos valores estipulados pelos fundadores." (Profissional Experiente 7)

"O comportamento político disfuncional é complexo porque ele é velado. Se você apresenta um projeto ou programa que lhe dá uma projeção, o outro funcionário, muitas vezes, utiliza de subterfúgios e cria dificuldades sob o manto de estar zelando pelo bem da organização. Ele jamais explicitará que se sentiu ameaçado. Em alguns casos, a menos que se consiga comprovar o comportamento disfuncional, a empresa não pode atuar diretamente. É possível que esse comportamento se esvazie sem que seja necessária a intervenção da organização. Quando não há argumentos que o sustentem, o comportamento disfuncional tende a se extinguir." (Profissional 4.2)

Foi possível perceber que os gestores entrevistados mencionaram a cultura da organização e o estilo de liderança como fatores que contribuem tanto para inibir o comportamento político funcional quanto para estimular o comportamento político difuncional. O grande desafio das organizações e seus gestores passa pelo gerenciamento adequado da cooperação e da competição. Algumas empresas possuem departamentos específicos para tratar os comportamentos disfuncionais. A ética, o exemplo, o desenvolvimento da consciência e o incentivo à participação foram vistos como fatores importantes para incentivar um comportamento político funcional.

Elaborou-se uma questão sobre o que gera uma boa reputação a uma liderança. $\mathrm{O}$ objetivo dessa pergunta foi verificar qual a visão sobre a reputação dos profissionais e se ela poderia ser associada às características descritas de um profissional competente politicamente.

"Acho que a integridade e a coerência" (Profissional Experiente 3)

"Integridade, honestidade e ética em primeiro lugar. Suas práticas precisam ser coerentes com o seu discurso. O líder não 
pode jamais denegrir a imagem da empresa, ameaçar a segurança do outro ou faltar com a ética e a honestidade. Eu chamo esses comportamentos de pecados capitais da organização." (Profissional Experiente 7)

"Uma coisa que eu considero muito importante para um líder é a coerência. Você pode ter um líder muito conservador, por exemplo, mas ele é coerente em todas as suas posturas e é respeitado por isso. As pessoas são diferentes, mas, dentro de suas visões de mundo e de suas práticas, é preciso haver coerência. O líder não tem que saber tudo. Ele precisa deter uma visão estratégica muito aguçada. Ele pode não ter tanto conhecimento técnico, mas, por meio da sua equipe e da sua visão aguçada, consegue construir um caminho de transformação. Essa capacidade do líder de enxergar e articular gera respeito. A liderança não precisa necessariamente ter domínio técnico. É positivo que ela o tenha, é lógico. Entretanto, muitas vezes, quando o líder é um expert, ele tende a não ter a capacidade de delegar." (Profissional 2.2)

"A base da reputação é o comprometimento ético. O que gera uma boa reputação, nesse campo dos conflitos interpessoais e das atuações políticas, é o comportamento ético. Algumas vezes, na minha carreira, eu tive oportunidade de fazer algo não tão ético para entregar um resultado que me colocaria em uma posição favorável, e eu sempre escolhi não fazê-lo. Isso foi essencial para que eu conquistasse a reputação que tenho hoje." (Profissional 3.2)

"A construção da reputação se dá socialmente - as pessoas que têm contato com uma liderança testemunham os resultados positivos das suas decisões e da sua forma de relacionamento. Mas já vi péssimos líderes bem avaliados e ótimos lideres com uma reputação ruim - resultado de suas habilidades políticas e de um pouco de sorte (ou azar)." (Profissional Experiente 1)

"É preciso ter competência política, paciência, saber negociar, ter uma visão holística, estratégica, enxergar o todo e uma visão sistêmica (interesses da organização e dos stakeholder). Mas o ponto principal é trazer resultado, entrega, performance. Sem isso, um profissional não se sustenta. $O$ resultado pode ser uma grandeza de curto prazo. Um resultado passado não garante um resultado futuro. $\mathrm{O}$ que garante um resultado futuro são outros atributos. Aí vem a questão da competência política, outras habilidades, mas, se não tem resultado, fica difícil explicar. Às vezes, você não apresenta resultado por outras razões e aí você pode até ter uma segunda chance, mas é só também, uma terceira chance já não acontece.” (Profissional Experiente 2). 
"Reconhecer a contribuição da equipe, celebrar com ela e traçar novos desafios. Quando o líder atinge bons resultados, as pessoas ficam prazerosas, pois percebem que estão sendo desenvolvidas. O papel de um líder é fazer com as pessoas sejam ainda melhores do que elas são. Se ele consegue isso, a equipe divulga o nome da liderança." (Profissional 3.1)

"A proximidade com os funcionários e o respeito são aspectos fundamentais. Ser uma pessoa justa também é muito importante. Quando eu acho que uma decisão não é positiva para minha equipe, eu tenho a coragem de dizer não e expor minha opinião a meus superiores." (Profissional 1.2)

"Estar sempre presente e disponível para auxiliar os seus subordinados é importante. Clareza e transparência são qualidades essenciais. O líder precisa ter a coragem de dizer que não sabe tudo sempre. É necessário saber dizer não de forma direta, mas respeitosa. A competência política também é fundamental." (Profissional 5.2)

"A coerência. As pessoas se sentem inspiradas pela energia, pela visão, pelo propósito, pela vontade e pelo envolvimento do líder. Entretanto, se não houver coerência, ética e verdade, a confiança e o respeito se perdem." (Profissional 6.2)

As definições de uma boa reputação, segundo os gestores entrevistados, corroboram a teoria existente sobre o tema. A realidade das organizações é baseada nas percepções, interpretações, imagens e impressões. A reputação é um construto mais sociopolítico do que científico, e apesar das dimensões da reputação serem pouco exploradas, os autores sugerem que pelo menos duas dimensões básicas e de ordem superior da reputação individual ou organizacional são performance/resultados e caráter/ integridade (FERRIS et al., 2003; FERRIS et al., 2016). Foi possível identificar que os itens mais citados estavam relacionados à performance ou resultados e coerência e comportamento ético. A reputação é um construto associado à confiança e é por meio dessa confiança que o profisssional adquire reputação, que serve como um diferencial no exercício da influência. Nesse sentido, o papel do comportamento passado contribui para a redução da incerteza em relação a um comportamento futuro, ou seja, trata-se do que é esperado por subordinados, pares e superiores. Por essa razão, as relações sociais têm um papel fundamental na definição da reputação. Isso porque a atribuição de reputação é moderada pela percepção dos motivos e intenções dos atores. Dessa forma, a boa reputação se relaciona com a competência política, uma vez que ela é construída 
nas interações sociais, e o comportamento ético é que contribui para sua a formação e manutenção.

A última pergunta relacionava-se ao significado de um líder legítimo. $\mathrm{O}$ propósito dessa questão era verificar qual é a visão de um líder legítimo e se essa ideia pode ser associada à competência política, ou seja, quais características de líderes legítimos podem ser associadas às características de profissionais competentes politicamente. Os trechos a seguir mostram o significado da legitimidade para os gestores:

"O líder legítimo é aquele que é admirado por seus funcionários, por seus pares e por seus superiores. Ele precisa ser uma pessoa assertiva, cuidadosa e atenciosa. É importante ter uma percepção e uma sensibilidade apurada em relação ao outro." (Profissional 1.2)

"O líder legítimo tem que ser aceito pelas partes mais importantes da empresa (stakeholders - acionistas, empregados e mercado). É preciso ter três elementos que pautam a legitimidade: confiança, respeito e admiração das pessoas. Tem que ter os três, não basta ter um ou dois desses itens. Se não tem respeito, não adianta; se não tem confiança, não tem como trabalhar; se não tem a admiração, você perde a graça, o simbolismo, o brilho. Esse profissional vale a pena! Eu admiro essa pessoa, ela faz e diz coisas bacanas." (Profissional Experiente 2)

"Tem uma frase do Peter Drucker que diz que o chefe é aquele que as pessoas seguem quando ele está presente e o líder é aquele que as pessoas seguem quando ele está ausente. Líder é a pessoa que inspira as demais. Ele se impõe por sua própria legitimidade. Embora a autoridade hierárquica funcional seja importante, quando o líder é legítimo, sua autoridade se expressa de forma natural e a hierarquia é relegada ao segundo plano." (Profissional Experiente 3)

"O líder legítimo é aquele que tem todas as qualidades para ser um líder. Ele sabe se relacionar de forma hábil com seus pares e subordinados, sabe motivar, sabe lidar com situações difíceis e sabe influenciar seus superiores. O líder legítimo deve ser um exemplo. O líder ilegítimo é aquele que não tem conhecimento para exercer sua função porque cresceu apenas politicamente. Isso existe muito também. Um líder que impõe sua autoridade somente pela pressão não é legítimo." (Profissional 2.1) 
"O líder legítimo é aquele reconhecido pelo grupo. O grupo tem prazer em seguir suas orientações, em ser influenciado por ele. A essência da liderança é a influencia, influência natural" (Profissional 3.1)

"Um líder legítimo é aquele que consegue convencer os demais não com sua fala, mas com seus atos. Ele precisa ser um exemplo. O líder deve ouvir e oferecer espaço para seus subordinados se expressarem. Ele precisa considerar seriamente as sugestões e as opiniões dos seus funcionários." (Profissional 4.2)

" $\mathrm{Na}$ atualidade, as pessoas não lideram pelo cargo, mas pelo que representam para os membros da equipe. O que gera a legitimidade é o reconhecimento das pessoas, que escolhem o líder para seguir. A liderança é uma questão de escolha. Vivemos em um ambiente de extrema liberdade. Esse é um contexto mundial. Os funcionários escolhem, ou não, seguir seus líderes. Cumprindo as regras da empresa e fazendo minimamente suas obrigações, o funcionário não precisa necessariamente seguir seu líder." (Profissional 3.2)

"O líder legítimo deve ser um exemplo para seus funcionários. É preciso haver coerência entre sua fala e seus atos. Um líder que diz prezar pela colaboração e não cumprimenta os funcionários não é coerente, por exemplo. É importante saber criar bons relacionamentos com todos.” (Profissional 1.1)

"É aquele que obtém os resultados esperados com o apoio e a satisfação de todos os envolvidos, sem autoritarismo. Eu sempre motivei minha equipe. Sempre disse que eu era resultado do grupo. Eu dava muito mérito e espaço aos meus funcionários." (Profissional Experiente 5)

"É aquele cuja autoridade não vem da estrutura. Ela vem da capacidade. A pessoa está ali por conhecimento e por capacidade." (Profissional Experiente 4)

"É aquele que inspira a equipe a caminhar junto com ele. Seus objetivos, crenças e propósitos são compartilhados pelo time. Ele não precisa nem da caneta, nem do carimbo." (Profissional 6.2)

"É alguém que reconheço estar alinhado com meus valores, ou que é capaz de apontar novos caminhos e possibilidades para a construção de uma sociedade melhor." (Profissional Experiente 1)

"Nas relações de grupo, você precisa primeiramente de uma legitimação. A atuação política vem desse relacionamento que, inicialmente, parte de uma legitimação. Legitimar-se significa 
demonstrar sua capacidade de agregar valor, sua competência e seu comprometimento com os objetivos comuns. Se o processo de legitimação não ocorre, é impossível o exercício da competência política. Você só consegue contribuir se houver essa base de confiança nos grupos em que está inserido. Outra coisa interessante é que, em alguns ambientes, você não pode ser percebido como uma ameaça. Quando você consegue se legitimar, você consegue interagir e transitar. Eu percebi que estava legitimado e que confiavam em mim quando as pessoas começaram a fazer questão da minha presença. Se eu me atrasasse para uma reunião, as pessoas me esperavam, por exemplo. No começo, eu era só mais um. Se eu aparecesse em uma reunião representando meu superior, as pessoas perguntavam por ele. No dia a dia, eu construí minha legitimação. Depois que você está legitimado, inicia-se um novo processo para legitimar o seu grupo. Essa outra etapa é importante porque, quando você atinge um alto grau de confiabilidade, você é convocado para tudo e torna-se necessário delegar algumas funções. Se eu era convocado para uma reunião, por exemplo, dizia que enviaria um assessor meu que era muito competente.” (Profissional 2.2)

O item atribuição de legitimidade foi fortemente associado às questões como reconhecimento, admiração, e confiança. Essa ideia corrobora a literatura sobre o tema, no sentido de que a legitimidade da liderança implica a aceitação dos liderados em relação à influência do líder. A competência política é uma competência relacionada à efetividade social que busca o atingimento de dois papéis importantes para uma liderança, que é o líder de equipe e o gestor de "arenas políticas", ambos fundamentais para a legitimação de uma liderança em relação aos seus subordinados, pares e superiores. Na discussão das proposições, examinar-se-ão mais detalhadamente a reputação e a legitimidade da liderança.

A seguir, realizam-se as análises dos dados obtidos nos estudos de casos.

\subsection{Análise dos dados dos estudos de caso}

\section{1.1 Estudo de Caso 1}

A empresa pesquisada é uma empresa privada da área de mineração. A empresa possui mais de 7500 funcionários no país e mais de 2000 na filial onde foi realizada a pesquisa. Foram entrevistados quatro gestores e o Diretor de Recursos Humanos. Esses gestores atuam em diferentes áreas da organização: comunicação, 
projetos, recursos humanos e estratégia. Foi solicitado à empresa que os profissionais tivessem cargos de gestão e, mesmo que não atuassem em uma mesma área, que eles fossem capazes de avaliar uns aos outros para atingir o propósito da pesquisa, ou seja, para permitir que os gestores, além de se autoavaliar em relação à competência política, pudessem avaliar seus pares. Todos os entrevistados responderam ao roteiro de entrevistas (12 perguntas abertas), assim como os questionários com perguntas fechadas do tipo escala likert (7 pontos) sobre competência política, reputação e legitimidade (versão autorrelato). No entanto não se conseguiu que todos os pares avaliassem uns aos outros, em razão de alguns estarem atuando há pouco tempo na empresa e não se sentirem confortáveis para realizar a avaliação. A pesquisadora foi orientada pelo Departamento de Recursos Humanos a solicitar a avaliação de desempenho diretamente aos profissionais, mas ela não obteve respostas dos entrevistados.

Faz-se, a seguir, uma breve exposição sobre o contexto (ambiente político da organização), o sistema de carreira e a visão sobre liderança, conforme relatos dos profissionais nas entrevistas.

\section{- Ambiente político}

“Esse é um ambiente de disputas. Há pessoas que focam muito nessas relações de poder em detrimento dos resultados e dos objetivos da organização.” (Profissional 1.1)

"As organizações diferem quanto aos seus ambientes políticos. $\mathrm{Eu}$ trabalhei em uma empresa muito tempo e ela me demandava uma atitude muito diferente daquela que a organização em que trabalho atualmente requer de mim. Cada organização tem uma cultura empresarial própria. Aqueles que ascendem profissionalmente são os que se adequam melhor à cultura da empresa. É necessário se adaptar ao ambiente e agir conforme suas regras. Evidentemente, isso não significa aceitar passivamente tudo que o ambiente lhe impõe, mas sim saber direcionar corretamente suas ideias e ações. Comparar as duas empresas onde trabalhei é interessante. A primeira tinha um caráter mais arrogante, um perfil mais autoritário em suas políticas, portanto o profissional precisava ser mais incisivo, mais firme nas suas opiniões. A necessidade de agradar os pares e liderados não era tão grande. Era preciso, basicamente, cumprir suas tarefas e funções. A organização em que trabalho hoje é mais cordial, mais amável. Existe uma maior preocupação com os funcionários e com questões sociais. Aqui é necessária uma preocupação maior com as relações. Há também uma maior 
preocupação com a carreira do funcionário em longo prazo. As experiências adquiridas nesses dois contextos empresariais distintos ajudaram a formar meu caráter como profissional." (Profissional 2.1)

“O ambiente político desta organização tem suas particularidades. Esta empresa surgiu como um projeto. Nós nunca tivemos falta de recursos, muito pelo contrário. $\mathrm{O}$ financeiro não era um problema para a empresa. Nós tínhamos os salários mais altos praticados no mercado, boas bonificações e bons benefícios. Contudo o resultado desse projeto não foi atingido e nós tivemos que mudar essa realidade. A cultura empresarial sempre foi muito voltada para o lado pessoal. Havia benefícios em excesso. Mudar essa situação está sendo muito difícil. Algumas pessoas não entendem que a realidade é outra." (Profissional 4.1)

"Nesta empresa, assim como nas demais multinacionais, além da hierarquia tradicional, há ramificações com a instituição matriz, que as pessoas utilizam para adquirir poder. Os profissionais criam essas relações paralelas para intensificar sua influência na tomada de decisões, que, muitas vezes, não são tão alinhadas ao presidente nacional. Portanto é possível ganhar poderes paralelos. O presidente sofre para unir a organização sob sua direção. Esse é um jogo constante. As decisões paralelas diminuem a influência do presidente, que tenta retomar esse poder. Essa é uma guerra típica das empresas multinacionais." (Profissional 5.1)

"Qualquer espaço de poder tem uma caracterização política e todo profissional é um pouco político. Ser político nada mais é do que ter habilidade de fazer alianças para alcançar objetivos. O importante é que esses objetivos comunguem com o bem da maioria e da organização." (Profissional 3.1)

\section{- Sistema de carreira}

"É comum um funcionário que desempenha muito bem uma função ser promovido como gratificação. Dessa forma, perde-se um excelente funcionário e se ganha um péssimo gerente, um líder ruim, pois ele se torna intransigente e autoritário. Eu penso inclusive que esse quesito é uma falha na avaliação de profissionais dentro das empresas. Às vezes, não se leva em consideração esse importante aspecto que é a competência política. Essa é uma grande falha dos planos de carreira e dos mapas de avaliação. Os quesitos de relacionamento e de desenvolvimento pessoal como líder são deixados de lado. Quando você promove uma pessoa inábil politicamente, são necessárias intervenções constantes; o que não aconteceria se o 
funcionário promovido soubesse lidar melhor com essas questões. Esse é um ponto fundamental na hora de se elegerem lideranças. A avaliação profisssional baseia-se muito na produtividade em detrimento de outras competências, como a competência política." (Profissional 2.1)

"Atualmente, é fundamental ter funcionários com habilidades multifuncionais. $\mathrm{O}$ profissional não trabalha apenas para determinado setor; ele trabalha para a organização como um todo. Devido a esse dinamismo, é essencial que ele tenha habilidade política. Um funcionário pode estar trabalhando em determinado processo em certo período, mas, em sua perspectiva de carreira, é planejado que ele vá para outro processo, para o seu próprio amadurecimento. Então, se essa pessoa possui relacionamentos apenas com seus colegas de trabalho da sua área, certamente terá dificuldades de adaptação no futuro." (Profissional 4.1)

"Estudamos se o candidato tem as competências necessárias para o cargo e pensamos também em como ele se adaptaria ao grupo de profissionais daquela área. Um bom psicólogo ou analista da área de Recursos Humanos consegue fazer essa matriz das relações de poder, identificando como aquela pessoa se integraria à equipe. Se uma pessoa com perfil inadequado para o grupo for inserida, a matriz de poder pode ser destruída e a equipe deteriorada. Existem vários testes que traçam o perfil de personalidade do candidato e, então, o analista pode fazer a composição do laudo. Há pessoas que, no traço de personalidade, já trazem uma tendência que demonstra um desejo absoluto pelo poder. Nesses casos, mesmo que a pessoa seja extremamente competente tecnicamente, imagina-se que ela trará dificuldades. Podemos fazer uma inferência com grande chance de acerto de que, ao longo do tempo, ela se perderá e sua competência não será utilizada para o bem da empresa." (Profissional 3.1)

Nas organizações, você só ascende se souber lidar com o aspecto político. Essa é uma competência que auxilia o seu crescimento. Essa habilidade não está tácita nas avaliações de performance, embora seja uma condição necessária à ascensão profissional. Contudo as pessoas que o avaliam e o indicam para possíveis promoções sabem se você trabalha bem com esse aspecto ou não. Se você não tem essa competência, você não sobrevive. É impossível ser só técnico no cumprimento da sua função. Eu já vi exemplos de pessoas tecnicamente muito competentes que negligenciaram o aspecto político. Na maioria das vezes, elas não permaneceram na organização. Esse comportamento não é sustentável. Por mais que seja possível desenhar organogramas, as áreas têm interfaces, overlaps. Você acaba esbarrando no escopo do outro, entrando na área do outro 
e utilizando recursos alheios. É preciso saber lidar com essas situações." (Profissional 5.1)

"Nos processos seletivos, tento explorar situações cotidianas da empresa e perceber como as pessoas reagem, buscando traços de cooperativismo e companheirismo. Eu sempre procuro pessoas que saibam promover o diálogo.” (Profissional 1.1)

\section{- Liderança}

"O líder deve ser capaz de criar experiências positivas. Ele deve ser coerente, transparente e não ter agendas ocultas. Ele precisa manter certa continuidade e previsibilidade em seu trabalho. É fundamental também que ele baseie suas relações em valores éticos." (Profissional 1.1)

"O líder deve possuir um grande conhecimento técnico, ser uma pessoa centrada, uma pessoa que sabe lidar com diferentes opiniões e que sabe direcionar de maneira correta as situações cotidianas. Ser uma pessoa que, no caos, não perca a cabeça. $\mathrm{O}$ líder é a única pessoa que não pode perder a cabeça. O líder precisa ter a capacidade de digerir os problemas que os subordinados lhe trazem, apresentando soluções, pensando junto e motivando-os." (Profissional 2.1)

"O líder deve ser uma pessoa que promove o desenvolvimento e que se preocupa com seu time. Ele precisa ser engajado na empresa e ter abertura para dialogar com todos. Saber receber feedbacks também é importante." (Profissional 4.1)

"Você, como líder, deve ser o role model da sua equipe. Todos enxergam os exemplos da liderança. Mesmo sendo um animal político, quando o líder demonstra bons exemplos, as pessoas veem com bons olhos seus comportamentos políticos. Desse modo, o profissional também faz uma gestão por constrangimento para inibir o comportamento disfuncional. Ele cria situações em que a pessoa com um comportamento disfuncional se expõe, portanto ele inibe esse tipo de atitude. Quando eu digo 'constranger' não me refiro à humilhação, muito pelo contrário. A gestão do exemplo e a gestão do constrangimento devem ser utilizadas conjuntamente. Você dá o exemplo e constrange o que não vai ao encontro daquela atitude. Dessa forma, as pessoas caminham com disciplina pelo caminho que você quer. Quando você age assim, você muda a cultura da organização.” (Profissional 5.1)

"Uma das minhas funções é desenvolver lideranças que saibam fazer conexões e alianças políticas, mas sempre com uma orientação ética, buscando alcançar os resultados necessários 
para a organização. Quem faz o papel dos Recursos Humanos de desenvolver as pessoas são os líderes. $\mathrm{Eu}$ tenho uma preocupação muito grande no processo de formação da minha equipe. Busco influenciá-los para que todos possam ser desenvolvedores de lideranças. O tempo todo, eu estou tentando mediar essas relações e ajudando a produzir um modelo de pensar que ande nessa direção.” (Profissional 3.1)

Em seguida, apresenta-se, no QUADRO 5, o comparativo entre as percepções sobre competência política dos profissionais entrevistados, seus pares e superior.

Quadro 5 - Comparativo avaliações competência política Estudo de Caso 1

\begin{tabular}{|c|c|c|c|c|c|c|c|c|c|c|}
\cline { 5 - 11 } & \multicolumn{9}{c|}{ Avaliação Pares } & \multicolumn{3}{c|}{ Avaliação Superior } \\
\hline Profissional & $\begin{array}{c}\text { Auto- Avaliação } \\
\text { CP }\end{array}$ & Pontuação & $\mathbf{1 . 1}$ & $\mathbf{2 . 1}$ & $\mathbf{4 . 1}$ & $\mathbf{5 . 1}$ & $\begin{array}{c}\text { Média } \\
\text { Pares }\end{array}$ & Pontuação & $\mathbf{3 . 1}$ & $\begin{array}{c}\text { Pontuação } \\
\text { Superior }\end{array}$ \\
\hline 1.1 & $\mathbf{6 , 1 3}$ & alta & - & 0,00 & 6,19 & 6,13 & $\mathbf{5 , 2 1}$ & $*$ média & $\mathbf{6 , 0 0}$ & alta \\
\hline 2.1 & $\mathbf{6 , 1 9}$ & alta & 4,25 & - & 3,19 & 5,56 & $\mathbf{5 , 1 3}$ & $*$ média & $\mathbf{4 , 8 8}$ & $*$ média \\
\hline 4.1 & $\mathbf{5 , 6 9}$ & média alta & 5,69 & 5,25 & - & 5,56 & $\mathbf{4 , 7 5}$ & $*$ média & $\mathbf{5 , 2 5}$ & média \\
\hline 5.1 & $\mathbf{5 , 7 5}$ & média alta & 5,69 & 5,00 & 4,88 & - & $\mathbf{5 , 7 5}$ & média alta & $\mathbf{6 , 1 9}$ & $*$ alta \\
\hline
\end{tabular}

* indica avaliações divergentes do autor-relato CP - Competência Política

Fonte: Elaborado pela autora.

Ao analisar o comparativo entre a autoavaliação e a avaliação de pares foi possível perceber que a percepção dos pares, nesse grupo de profissionais, apresentou valores sempre abaixo da autoavaliação em notas e, em alguns casos, na pontuação também. O mesmo ocorre na avaliação do superior, em que as notas na maioria dos casos são menores que as da autoavaliação. Uma razão possível para essa diferença pode estar relacionada ao fato de as pessoas terem uma autoimagem positiva e, pelas descrições e questões relacionadas à competência política, apresentarem uma simplicidade aparente, mas que, na verdade, disfarça a complexidade da sua aplicação na prática, como: "eu entendo muito bem as pessoas". Entender bem as pessoas, verdadeiramente, pode ser uma tarefa mais difícil do que aparenta ser por envolver a compreensão de aspectos amplos do indivíduo. Uma exceção foi o profissional 5.1 que teve o valor da autoavaliação e pontuação igual à média dos seus pares e a nota do superior sendo um valor acima daquela dada por ele.

\subsubsection{Estudo de Caso 2}


A empresa pesquisada é uma instituição financeira de economia mista com mais de 100.000 funcionários. Foram entrevistados cinco gestores que respondem diretamente ao Diretor de Gestão de Pessoas, que também foi entrevistado. Esses gestores são responsáveis pelo relacionamento de suas áreas com as demais áreas da empresa e com o mercado. A ideia de entrevistar profissionais de uma mesma área de atuação se deu em razão da acessibilidade e também pela sua aderência ao propósito da pesquisa. Imagina-se que, quanto mais próximo o relacionamento dos profissionais, mais clara é a sua percepção sobre o outro para avaliação dos pares. Todos os entrevistados responderam tanto ao roteiro de entrevistas abertas (12 questões) quanto a autoavaliação sobre a competência política, reputação e legitimidade. Foi solicitada a avaliação de desempenho dos profissionais como dados secundários da pesquisa, mas ela não foi disponibilizada. Os relatórios com as perguntas fechadas sobre competência política, reputação e legitimidade (versão pares) foram preenchidos por quase todos os participantes da pesquisa com algumas poucas exceções. Nessa empresa, conseguiu-se, inclusive, a avaliação do superior (diretor) sobre seus subordinados.

Far-se-á uma breve exposição sobre o contexto (ambiente político da organização), o sistema de carreira e a visão sobre liderança, conforme relato nas entrevistas.

\section{- Ambiente político}

"Nesta organização, eu trabalho em um departamento muito abrangente, a área de pessoas. Ela interage com todos os departamentos da organização. Qualquer tipo de projeto ou frente que se abra na instituição passa pela área de pessoas. Isso nos dá uma interação constante com a Diretoria Executiva. Nós temos o Conselho de Administração, um órgão estratégico que não faz parte do dia a dia da empresa, e que delimita o objetivo estratégico maior. Existe também a Diretoria Executiva, que exerce e executa o plano estratégico cotidianamente. Essa diretoria tem dois grandes órgãos, o Conselho Diretor, que engloba o presidente e os vice-presidentes, e as diretorias. Devido a essa estrutura, tudo é compartilhado na organização. Existe um compromisso enorme para com a empresa que faz com que tudo seja muito debatido para evitar qualquer tipo de risco. Nós somos muito cuidadosos na gestão e preocupados com o bom andamento dos processos. Eu acho inclusive que, por causa disso, temos um pouco de dificuldade em lidar com o erro. Queremos acertar o tempo todo; o que gera uma cobrança das pessoas. $\mathrm{O}$ ambiente político é extenso; temos 
aproximadamente quarenta pessoas comandando a empresa. Esse nível de governança demasiadamente organizada traz segurança e transparência, mas traz também certa morosidade à nossa condição de resposta, que precisa sempre ser rápida. Contudo esse é um ambiente muito bom para trabalhar. As pessoas estão aqui para tentar atingir objetivos comuns. Temos muita clareza dos desafios da organização. Nós precisamos ser muito cuidadosos devido à grandeza da empresa. Nossas decisões causam desdobramentos que impactam a vida de milhares de funcionários. Inevitavelmente, algumas pessoas serão agradadas e outras serão desagradadas; mas há sempre a certeza de que os valores institucionais são maiores do que as rusgas cotidianas." (Profissional 6.2)

"Eu observo que, embora esta seja uma empresa de economia mista, ela começa a desenvolver características de organizações privadas. A competitividade atualmente é maior. A empresa cresceu em todas as áreas e compete de igual para igual com as demais. Porém eu sinto falta de uma maior autonomia para o executivo. As decisões estão muito focadas na figura do diretor. Ainda existe um sistema de autoridade muito forte. É curioso perceber que alguns diretores pedem, em seus discursos, criticidade e inovação, mas, na prática, as coisas não ocorrem dessa maneira, depende muito do perfil do diretor, se ele é mais inovador. De modo geral, nosso grupo de diretores dialoga constantemente e de maneira muito respeitosa. Existe certa harmonia e homogeneidade, o que é essencial para a organização.” (Profissional 1.2)

"Eu percebo essa empresa como altamente hierarquizada, rígida, machista, mas com funcionários que têm uma força de trabalho imensa e um vínculo muito grande com a organização e seus interesses. O nível de governança desta organização é altíssimo, o que poderia ser positivo, mas, na realidade, não o é. O nosso nível de governança é tão alto que acaba limitando o processo decisório e tornando a empresa demasiadamente burocrática. Todas as decisões partem de um colegiado. Então, nas situações em que o gestor deveria tomar uma decisão, ele tende a não o fazer porque está acostumado a decidir conjuntamente. Isso é uma conquista do ponto de vista da governança. Por outro lado, nós precisamos ser competitivos, rápidos e eficientes, e o estado vigente das coisas não propicia isso. Se a estrutura da organização é profundamente hierárquica, não há contrariedades. Isso é nocivo para a empresa. É claro que as estruturas hierárquicas existem para dar um sentido e uma lógica ao funcionamento organizacional, mas é nítido que a empresa extrapola nesse aspecto." (Profissional 2.2)

"Nas instituições financeiras, o ambiente político é bastante peculiar. Existe uma estrutura militarizada e hierarquizada, mas 
colegiada na decisão. Portanto esse ambiente favorece a incompetência das pessoas. $\mathrm{O}$ ambiente político dilui a responsabilidade dos profissionais. Suas ações e decisões tornam-se menos assertivas. As pessoas são inibidas de se expressar livremente. Esse ambiente enfraquece as competências e as individualidades; ocorre certa padronização dos funcionários. Isso acirra as disputas porque as oportunidades de encarreiramento, diante das decisões colegiadas, dependem mais da imagem que você consegue criar de si e de sua rede de influência do que das suas verdadeiras habilidades. $O$ apadrinhamento é frequente. O "pedigree" da pessoa é muito importante também, de quem ela é filha, com quem ela é casada etc." (Profissional 5.2)

\section{- Sistema de carreira}

"Durante muito tempo, nosso mecanismo de ascensão era basicamente o resultado. Nos últimos anos, nós percebemos que usar somente o resultado não era suficiente. Um gestor que gerava um resultado excelente, muitas vezes, não conseguia sustentá-lo pela inabilidade política. Hoje, temos um sistema seletivo que busca analisar outras dimensões. A partir desse instrumento, é gerada uma pontuação para o programa de ascensão profissional. Nós evoluímos muito em relação a esses instrumentos que mostram ao funcionário o que a empresa entende como sendo um bom líder, quais são suas características." (Profissional 4.2)

"As carreiras são muito bem estruturadas e as formas de ascensão são claras e definidas. Temos um sistema de concorrência que avalia talentos e oportunidades. Ele captura a formação do funcionário e a sua experiência. Quando aparece uma vaga, o profissional registra sua intenção e pode, então, participar do processo seletivo. O sistema gera um ranking e alguém, entre os primeiros colocados, é nomeado. O gestor que ocupava a vaga tem a prerrogativa de escolher entre os mais bem classificados. Ele, normalmente, pede auxílio ao departamento de gestão de pessoas para escolher o candidato mais adequado. O sistema ajuda os funcionários no seu crescimento profissional, pontuando claramente quais são os critérios de seleção.” (Profissional 1.2)

"Nos processos seletivos, analisamos atitude, nível de motivação, visão estratégica e habilidade de comunicação e de liderança, o que não pode ser medido do ponto de vista de formação e experiência. Nós queremos que o profissional seja capaz de fazer uma boa gestão, envolvendo as pessoas, conseguindo mobilizá-las em torno de metas comuns, dando feedbacks e auxiliando em suas formações. Aqui na 
organização, observamos todas essas dimensões, tentando escolher a pessoa com o perfil que mais se adeque à função." (Profissional 6.2)

"A nossa empresa tem um modelo de ascensão muito objetivo, claro e transparente. Ele está associado a duas estruturas básicas: a experiência profissional dentro da organização e a formação curricular. Isso funciona perfeitamente dentro da empresa e todas as estruturas de ascensão passam por esse sistema. Por outro lado, nós sabemos que isso é muito limitante. Conhecer uma pessoa sem analisar outras perspectivas é muito difícil. Muitas vezes, eu questiono se os profissionais que o sistema selecionou são realmente os melhores. $\mathrm{O}$ mais importante não é o título ou a formação acadêmica, senão a forma com que o profissional experimenta essa formação. O fundamental é estabelecer uma relação com o conhecimento e com o processo de aprendizado.” (Profissional 2.2)

"Nós temos um ambiente político que, de certo modo, reproduz o ambiente político brasileiro, no sentido da diversidade. Quando eu digo político, não me refiro ao sentido partidário, mas ao sentido das relações interpessoais comunitárias. Se o profissional seguir os passos, os valores e os encaminhamentos que a empresa lhe oferece, há chances de ele se tornar presidente. Isso é muito motivador. Há um sistema de ascensão extremamente democrático. Os funcionários podem concorrer para qualquer função que quiserem, e os requisitos são explicitados. Outro aspecto essencial para ascensão profissional são as redes de relacionamento. Não basta somente ser bom. A organização é uma reprodução da sociedade brasileira. Se o funcionário for um bom vendedor e tiver uma boa rede de relacionamentos, ele possui grandes chances de acender rapidamente, mas, se esse processo não estiver fundamentado nos valores e princípios da organização, o crescimento não é sustentável. O funcionário ficará estagnado ou poderá inclusive decair." (Profissional 3.2)

\section{- Liderança}

“O nosso referencial de liderança, na organização, é aquele profissional que consegue equilibrar as três dimensões: pessoas, resultados e processos. Há uma década, os resultados eram o único aspecto analisado ao se promover um profissional. Percebeu-se, então, que a gestão envolve muitas outras dimensões." (Profissional 1.2)

"Eu vejo muito claramente que o sucesso do líder está em fazer com que sua equipe, sua unidade, atinjam os objetivos esperados. É necessário fazer o papel de mediador entre o 
cumprimento das metas de curto prazo e os interesses de longo prazo, como a formação e o desenvolvimento de valores. É preciso negociar muito para atingir o equilíbrio das três dimensões: negócios, pessoas e processos. Quanto mais complexa é a liderança que um profissional assume, mais o seu sucesso depende de bons relacionamentos e de boas relações políticas. O líder tem responsabilidade pessoal pelos resultados daquela unidade que ele gerencia, mas a capacidade de resposta é coletiva. Por exemplo, um superintendente não consegue entregar os resultados apenas pelas competências que ele tem. Ele precisa ser um bom articulador para que todas as equipes consigam entregar os resultados. Ele tem que transigir pelos nuances da luta pelo poder e da busca por reconhecimento. $\mathrm{O}$ líder, nessa organização, tem um trabalho muito forte, pois ele lida com uma diversidade de opiniões muito grande. Ele precisa ser um bom mediador para que a equipe consiga atingir os resultados que a organização espera. Portanto eu considero a dimensão política fundamental." (Profissional 3.2)

"Eu acredito que o líder precisa ter a capacidade de perceber essas disputas e de saber a hora e o modo certos de intervir. Por outro lado, é preciso orientar os profissionais que não estão cumprindo corretamente seus papéis. O líder não pode ter medo de criticar construtivamente seus liderados. Sinceridade e transparência são valores essenciais." (Profissional 6.2)

Em seguida, apresenta-se o QUADRO 6, com o comparativo entre as percepções sobre competência política dos profissionais entrevistados, seus pares e superior.

Quadro 6 - Comparativo avaliações competência política Estudo de Caso 2

\begin{tabular}{|c|c|c|c|c|c|c|c|c|c|c|c|}
\cline { 5 - 11 } & \multicolumn{9}{c|}{ Avaliação Pares } & \multicolumn{2}{c|}{ Avaliação Supe rior } \\
\hline Profissional & $\begin{array}{c}\text { Auto- Avaliação } \\
\text { CP }\end{array}$ & $\begin{array}{c}\text { Pontuação } \\
\text { autor-relato }\end{array}$ & $\mathbf{1 . 2}$ & $\mathbf{2 . 2}$ & $\mathbf{3 . 2}$ & $\mathbf{4 . 2}$ & $\mathbf{5 . 2}$ & $\begin{array}{c}\text { Média } \\
\text { Pares }\end{array}$ & $\begin{array}{c}\text { Pontuação } \\
\text { média pares }\end{array}$ & $\begin{array}{c}\mathbf{6 . 2} \\
\text { Pontuação } \\
\text { superior }\end{array}$ \\
\hline 1.2 & $\mathbf{6 , 7 5}$ & alta & - & 5,19 & 6,75 & 6,88 & 6,56 & $\mathbf{5 , 8 6}$ & $*$ media alta & $\mathbf{5 , 8 1}$ & $*$ média alta \\
\hline 2.2 & $\mathbf{5 , 6 3}$ & média alta & 5,31 & - & 6,13 & 4,75 & 3,38 & $\mathbf{4 , 6 1}$ & $*$ média & $\mathbf{5 , 3 1}$ & $*$ média \\
\hline 3.2 & $\mathbf{6 . 0 6}$ & alta & 6,31 & 4,56 & - & 5,75 & 6,75 & $\mathbf{6 , 2 3}$ & alta & $\mathbf{6 , 3 8}$ & alta \\
\hline 4.2 & $\mathbf{5 , 8 8}$ & média alta & 6,19 & 4,88 & 5,81 & - & 6,44 & $\mathbf{5 , 6 0}$ & média alta & $\mathbf{5 , 6 3}$ & média alta \\
\hline 5.2 & $\mathbf{5 , 5 0}$ & média alta & 5,63 & 3,81 & 0,00 & 5,00 & - & $\mathbf{5 , 7 8}$ & média alta & $\mathbf{5 , 6 9}$ & mé dia alta \\
\hline
\end{tabular}

* indica avaliações divergentes do autor-relato CP - Competência Política

Fonte: Elaborado pela autora.

Ao analisar a comparação entre avaliações (pares/superior com autoavaliações) foi possível observar que a percepção dos profissionais foi coerente com a classificação da pontuação da autoavaliação dos gestores, exceto na avaliação do profissional 1.2, que 
se autoavaliou com um nível de competência política alta e seus pares e superior o avaliaram com competência política média alta, mesmo que a avaliação também tenha sido de média alta. Por outro lado, observa-se que, na maioria das vezes, apesar de a pontuação indicar o mesmo nível de pontuação da autoavaliação, as notas dos pares e superior se mostraram com valores um pouco abaixo da nota da autoavaliação, com uma ressalva para os profissionais 3.2 e 5.2 cuja nota da autoavaliação foi menor que a dos pares e do superior. É possível dizer que essa percepção mais próxima entre os profissionais (gestor, pares e superior) talvez aconteça nesse grupo por ser uma empresa de economia mista. Isso porque esse grupo de trabalho apresenta características mais estáveis, em razão de os profissionais permanecerem durante toda a carreira na mesma empresa, o que faz com que as pessoas se conheçam melhor e, possivelmente, pelo nível de competitividade interna ser relativamente menor do que em empresas privadas, onde essa estabilidade não é tão presente. O superior não foi avaliado por seus subordinados. Isso porque estudiosos sobre o tema apontaram que existe uma limitação na percepção dos subordinados em relação à complexidade da "arena política" dos seus superiores pela falta de vivência nessa esfera. 


\section{CONCLUSÃO}

Primeiramente, discutem-se as conclusões sobre as quatro proposições elaboradas no presente estudo.

Para responder à Proposição 1 - As lideranças brasileiras consideram-se e são percebidas (pares, superiores ou gestores de RH) como politicamente competentes, utilizaram-se as respostas das questões abertas 5 e 7 e o questionário de autorrelatos sobre competência política. Os dados da TAB. 8, a seguir, mostram os resultados obtidos na autoavaliação dos gestores sobre suas competências políticas, incluindo a análise das quatro dimensões críticas: astúcia social, influência interpessoal, habilidade de network e sinceridade evidente e sua pontuação.

Tabela 8 - Geral Auto-avaliação Dimensões Competência política

\begin{tabular}{|c|c|c|c|c|c|c|c|c|c|}
\hline & Grupo de Profissionais & Cargo & idade & \begin{tabular}{r|} 
Astúcia \\
Social \\
\end{tabular} & $\begin{array}{c}\text { Influência } \\
\text { Interpessoal }\end{array}$ & Network & $\begin{array}{c}\text { Sinceridade } \\
\text { Evidente }\end{array}$ & $\begin{array}{l}\text { Nota CP total } \\
\text { Auto-avaliação }\end{array}$ & $\begin{array}{c}\text { Pontuação } \\
\text { CP } \\
\end{array}$ \\
\hline 1 & Profissional Experiente & Vice Presidente de RH & 56 & 5,25 & 5,50 & 5,40 & 6,33 & 5,56 & média alta \\
\hline 2 & Profissional Experiente & Diretor Regional & 62 & 6,25 & 6,75 & 5,80 & 7,00 & 6,38 & alta \\
\hline 3 & Profissional Experiente & Presidente & 63 & 5,00 & 6,00 & 6,00 & 6,33 & 5,81 & média alta \\
\hline 4 & Profissional Experiente & Superintendente Comercial & 54 & 5,50 & 6,00 & 5,00 & 6,67 & 5,69 & média alta \\
\hline 5 & Profissional Experiente & Vice Presidente & 78 & 5,25 & 5,00 & 5,20 & 6,00 & 5,31 & média \\
\hline 6 & Profissional Experiente & Diretor Proprietário & 61 & 7,00 & 7,00 & 6,40 & 7,00 & 6,81 & alta \\
\hline 7 & Profissional Experiente & Diretora de RH & 64 & 6,00 & 5,50 & 6,00 & 6,67 & 6,00 & alta \\
\hline 8 & Profissional Experiente & Diretor Proprietário & 58 & 4,50 & 6,25 & 5,40 & 7,00 & 5,69 & média alta \\
\hline 9 & Profissional Experiente & Vice de Presidente de RH & 70 & 5,25 & 6,00 & 6,20 & 6,33 & 5,94 & média alta \\
\hline 10 & Profissional Experiente & Diretor de RH & 42 & 5,25 & 5,50 & 5,20 & 7,00 & 5,63 & média alta \\
\hline \multicolumn{2}{|r|}{ Média } & & & 5,53 & 5,95 & 5,66 & 6,63 & 5,88 & média alta \\
\hline 11 & Estudo de Caso 1 & Gerente de comunicação & 39 & 6,00 & 5,75 & 5,60 & 6,33 & 6,13 & alta \\
\hline 12 & Estudo de Caso 1 & Gerente de Projetos & 48 & 5,75 & 5,75 & 5,40 & 6,33 & 6,19 & alta \\
\hline 13 & Estudo de Caso 1 & Diretor de RH & 51 & 5,75 & 6,50 & 6,20 & 7,00 & 6,63 & alta \\
\hline 14 & Estudo de Caso 1 & Gerente de Rel. Trabalhistas & 34 & 5,00 & 5,25 & 5,00 & 7,00 & 5,69 & média alta \\
\hline 15 & Estudo de Caso 1 & Gerente (Head of Strategy) & 39 & 4,75 & 5,25 & 5,80 & 5,33 & 5,75 & média alta \\
\hline \multicolumn{2}{|r|}{ Média } & & & 5,45 & 5,70 & 5,60 & 6,40 & 6,08 & alta \\
\hline 16 & Estudo de Caso 2 & Gerente Executivo & 50 & 6,00 & 6,50 & 6,20 & 7,00 & 6,75 & alta \\
\hline 17 & Estudo de Caso 2 & Gerente Executivo & 48 & 4,75 & 4,50 & 6,20 & 7,00 & 5,63 & média alta \\
\hline 18 & Estudo de Caso 2 & Gerente Executivo & 56 & 5,00 & 5,75 & 5,80 & 6,67 & 6,06 & alta \\
\hline 19 & Estudo de Caso 2 & Gerente Executivo & 53 & 5,25 & 6,00 & 4,80 & 6,67 & 5,88 & média alta \\
\hline 20 & Estudo de Caso 2 & Gerente Executivo & 47 & 4,50 & 4,75 & 5,20 & 7,00 & 5,50 & média alta \\
\hline 21 & Estudo de Caso 2 & Diretor de RH & 50 & & & & & - & \\
\hline \multicolumn{2}{|r|}{ Média } & & & 5,10 & 5,50 & 5,64 & 6,87 & 5,96 & média alta \\
\hline & Média Geral & \multicolumn{3}{|r|}{5,36} & 5,72 & 5,63 & 6,63 & 5,97 & mé dia alta \\
\hline
\end{tabular}

Fonte: Elaborada pela autora.

Segundo a tabela de pontuação elaborada por Ferris et al. (2005), as respostas devem ser divididas pelo número de perguntas para se chegar ao resultado final. Tendo em vista que as questões 1 e 18 foram eliminadas, utilizaram-se as 16 perguntas de 2 a 17 e dividiu-se o resultado obtido por 16. Os números a seguir representam o grau de competência política: 1 e 2 - Baixa competência política, 3,4 e 5 - Média competência política, 6 e 7 - Alta competência política. Considerou-se, ainda, que as notas acima de 
5,5 seriam consideradas média alta. Os resultados mostram que os gestores entrevistados se avaliaram de maneira positiva em relação à competência política, sendo que $40 \%$ dos entrevistados se classificaram na pontuação alta, 55\% na média alta e 5\% na média. Os altos índices de competência política apresentados no grupo de profissionais entrevistados indicam uma concordância com a ideia apresentada nesta pesquisa de que gestores precisam atuar politicamente para alcançarem efetividade organizacional. As possíveis razões para esses resultados positivos podem estar relacionada ao fato de os entrevistados ocuparem cargos altos de gestão, ou seja, esses profissionais podem ter desenvolvido essa competência ou a competência política pode ter sido um fator importante que contribuiu para o desenvolvimento na carreira desses profissionais para o nível gerencial. Outra possível razão seria a questão cultural brasileira, que valoriza as interações sociais e que reconhece o papel das relações interpessoais no aumento da influência social. Os dados mostram que não houve uma diferença significativa entre as dimensões críticas, todavia percebeu-se que os profissionais se classificaram com as menores notas na dimensão astúcia social e com as maiores notas na dimensão sinceridade evidente.

Foi realizada uma análise estatística básica considerando valores máximo e mínimo, média, desvio padrão e coeficiente de variação (BUSSAB; MORETTIN, 1987) em relação às respostas obtidas nas perguntas de 2 a 17 do questionário traduzido para o português para mensuração da competência política, conforme TAB. 9, a seguir.

\begin{tabular}{|l|r|r|r|r|r|r|r|r|r|r|r|r|r|r|r|r|}
\hline Tabela 9 - Estatísticas básicas respostas Competência Políica & $\mathbf{4}$ & $\mathbf{3}$ & $\mathbf{4}$ & $\mathbf{5}$ & $\mathbf{6}$ & $\mathbf{7}$ & $\mathbf{8}$ & $\mathbf{9}$ & $\mathbf{1 0}$ & $\mathbf{1 1}$ & $\mathbf{1 2}$ & $\mathbf{1 3}$ & $\mathbf{1 4}$ & $\mathbf{1 5}$ & $\mathbf{1 6}$ & $\mathbf{1 7}$ \\
\hline Perguntas & $\mathbf{2}$ & 4 & 6 & 3 & 2 & 4 & 4 & 4 & 5 & 3 & 2 & 6 & 5 & 4 & 4 & 4 \\
\hline Mánimo & $\mathbf{4}$ & $\mathbf{7}$ & $\mathbf{7}$ & $\mathbf{7}$ & 6 & $\mathbf{7}$ & $\mathbf{7}$ & $\mathbf{7}$ & 7 & 7 & 7 & 7 & 7 & 7 & 7 & 7 \\
\hline Média & 6,050 & 5,750 & 6,250 & 5,250 & 4,950 & 5,550 & 6,700 & 5,850 & 5,900 & 5,450 & 5,050 & 6,750 & 6,450 & 5,750 & 5,400 & 5,400 \\
\hline Desvio padrão & 0,759 & 0,786 & 0,444 & 1,209 & 0,999 & 0,826 & 0,733 & 0,875 & 0,553 & 0,999 & 1,356 & 0,444 & 0,686 & 0,851 & 0,821 & 0,681 \\
\hline CV & 0,125 & 0,137 & 0,071 & 0,230 & 0,202 & 0,149 & 0,109 & 0,150 & 0,094 & 0,183 & 0,269 & 0,066 & 0,106 & 0,148 & 0,152 & 0,126 \\
\hline
\end{tabular}

Fonte: Elaborada pela autora.

A tabela acima mostra que $50 \%$ das respostas obtidas nos valores mínimos apresentaram a opção de escolha 4 (neutro). Já os valores máximos se apresentaram altos, sendo que 93\% das respostas se localizam na nota máxima 7 (concordo totalmente). Segundo Martins e Theóphilo (2007), os resultados do coeficiente de variação podem apontar que: abaixo de 0,15 , os dados variam pouco; entre 0,15 e 0,30 variam moderadamente; acima de 0,30 variam demais. Acima de 0,30, a média nem pode ser considerada como síntese do grupo. Os resultados das respostas às perguntas 
apresentaram um coeficiente de variação na maioria das perguntas valores abaixo de 0,15 , por essa razão, pode-se concluir que a média é representativa do grupo por não ser muito dispersa. As notas altas demonstram que o grupo de entrevistados apresenta altos índices de competência política. Esses dados corroboram as respostas qualitativas do estudo, em que os gestores se classificaram como competentes politicamente e mostraram que a competência política é considerada por eles como fator fundamental para atuação e desenvolvimento na carreira no nível de gestor. Assim, a competência política foi percebida como relevante por todos os profissionais entrevistados, o que inclui os gestores, pares, superiores e gestores de RH.

Nas respostas qualitativas, alguns profissionais relataram nunca terem pensado no aspecto político das suas atitudes e comportamentos. No entanto, apesar de não terem a consciência ou mesmo lidarem com a nomenclatura "competência política", segundo eles, esse aspecto político faz sentido e foi fundamental para o desenvolvimento de suas carreiras nas organizações. Foi possível perceber que a competência política é uma competência percebida como cada vez mais importante no ambiente organizacional contemporâneo, em que predomina uma gestão mais democrática, com menos níveis hierárquicos, que demanda mais interações sociais e onde as fronteiras das funções são menos rígidas e as mudanças e ambiguidades se tornam mais constantes e intensas.

Para Mintzberg (1979), o que diferencia um gestor de um bom líder é que a autoridade formal confere ao gerente um grande poder potencial, mas é a liderança que determinará o quanto de poder que ele vai conseguir obter. A essência do conceito de liderança é o exercício da influência (BASS, 2008). Mintzberg (1985) descreveu os quatro sistemas de influência presentes na organização, quais sejam os sistemas de autoridade, ideologia, de expertise e o sistema político. O sistema da autoridade está relacionado ao poder formal, alocado de forma explícita e sancionado legalmente. $\mathrm{O}$ sistema de ideologia, apesar de implícito, tipicamente representa normas e crenças que são amplamente aceitos na organização, já que os assuntos são interpretados por meio do conjunto de crenças vigentes. O sistema de expertise é aquele em que as pessoas tendem a submeter-se a um expert no assunto em questão. Já o sistema político, em contraste com esses sistemas, pode ser descrito como capaz de refletir um poder precisamente legítimo em seu significado e seus fins. Isso porque o sistema político permite o debate, enquanto os outros sistemas promovem apenas uma visão parcial. 
Apesar da importância relativa do sistema de influência de autoridade estar diminuindo em razão das mudanças nas estruturas e nos conceitos de carreira, todos os sistemas de influência são importantes para o exercício da liderança, tendo em vista que ela é um processo de influência. No entanto esta pesquisa mostrou que, em razão de o aspecto político ter uma conotação negativa e ser considerado um tabu, ele é pouco explorado e treinado pelas organizações e seus profissionais. Percebe-se que o sistema de influência político, por suas características discutidas nesta pesquisa, apresenta-se adequado à realidade contemporânea, em que o ambiente organizacional passa por mudanças constantes e é cada vez mais ambíguo e complexo. Nesse sentido, é que se observa que, atualmente, as lideranças precisam trabalhar todos os sistemas de influência, inclusive - e talvez principalmente - o sistema de influência político.

Uma análise estatística comparativa entre os grupos entrevistados foi realizada, conforme a TAB. 10, a seguir.

Tabela10 - Estatísticas comparativas entre grupos de entrevistados

\begin{tabular}{|l|r|r|r|}
\hline Grupos & Média de Nota CP & Desvio padrão & CV \\
\hline Estudo de Caso 1 & 6,078 & 0,380 & 0,063 \\
\hline Estudo de Caso 2 & 5,964 & 0,490 & 0,082 \\
\hline Profissional Experiente & 5,882 & 0,435 & 0,074 \\
\hline Total Geral & $\mathbf{5 , 9 5 1 5}$ & $\mathbf{0 , 4 2 1}$ & $\mathbf{0 , 0 7 1}$ \\
\hline \multicolumn{3}{|l}{} \\
\hline CP Competência política
\end{tabular}

Fonte: Elaborada pelo autor.

Essa análise mostrou que não há diferenciação entre os grupos de entrevistados, ou seja, que os grupos apresentam características homogêneas. Esse resultado corrobora a ideia de a atuação na "arena política" ser necessária para a efetividade dos gestores no ambiente organizacional, independentemente das particularidades desses contextos. Desse modo, a competência política passa a ser vista como uma competência importante para as empresas e seus profissionais. No entanto questões como a intensidade e forma que levam a variações na demanda da competência política em relação aos diferentes contextos merecem ser avaliadas em estudos futuros. Outra razão provável para essa homogeneidade do grupo poder estar relacionada ao fato de os gestores participantes desta pesquisa serem profissionais de alto nível, ou seja, são 
ou foram ocupantes de altos cargos nas organizações, representando, de certa maneira, um grupo específico que pode ser considerado um grupo "elite" de gestores.

A fim de avaliar a Proposição 2 -, Os aspectos positivos do ambiente político nas organizações e da função política do gestor são percebidos pelos profissionais brasileiros, foram usadas as respostas às questões 1, 2, 9 e 10.

Tendo em vista a conotação negativa da palavra política, que, muitas vezes, é confundida com a política partidária - o que acaba contribuindo ainda mais para a visão negativa do conceito devido aos constantes e recentes escândalos de corrupção, envolvendo tanto as esferas públicas como privadas, seria de imaginar que a percepção do ambiente político e do aspecto político da função da liderança fosse predominantemente negativa. No entanto, constatou-se que os profissionais percebem o papel político da função do gestor como fundamental para a efetividade do profissional e que o ambiente é, sim, político, em razão das interações sociais e das disputas e conflitos que são inerentes à condição humana. Eles conseguem ainda identificar claramente os benefícios disso para o desenvolvimento em suas carreiras. Esses achados corroboram o estudo de Fedor et al. (2008), que mostrou que, apesar de se esperar que o comportamento negativo fosse mais percebido, os membros da organização percebem tanto o comportamento positivo quanto o negativo.

Percebeu-se que o conceito de competência política se mostra, de maneira geral, aderente aos valores e à cultura nacional. Isso porque a sociedade brasileira é uma sociedade relacional, em que soluções violentas são evitadas, dando-se preferência às conciliações e amizades. Os profissionais valorizam aqueles tidos como politicamente competentes. A flexibilidade, capacidade de adaptação, criatividade, amabilidade e abertura para o outro, que são considerados traços típicos do povo brasileiro, podem ser também considerados como traços que contribuem para o desenvolvimento de competências políticas das lideranças brasileiras, para a construção de um ambiente de respeito e para a resolução de conflitos. Por outro lado, pode haver uma dificuldade real por parte de alguns gestores brasileiros em acompanhar a tendência de ambientes mais democráticos e, portanto, mais participativos e críticos, já que traços como desigualdade de poder, hierarquia e aversão a conflitos se mantiveram. Nesse sentido, gestores acostumados ao autoritarismo e à passividade típica de subordinados em razão dos traços de postura de expectador, de evitar conflito e de manutenção do status quo, encontrarão dificuldades em se adaptar a um ambiente menos hierarquizado. Da mesma forma, aqueles profissionais avessos a conflitos podem se sentir desafiados no 
enfrentamento dos conflitos inerentes ao ambiente, gerando a dificuldade de falar não, entre outras. É possível perceber que as mudanças no contexto das organizações no âmbito mundial impõem mudanças relacionadas às estruturas de poder, relações profissional/empresa que incentivem a maior participação de todos, de modo que se torna fundamental uma maior criticidade tanto das lideranças quanto dos subordinados.

É preciso observar que defender a necessidade de um ambiente organizacional mais democrático é, certamente, mais fácil do que sua prática. $\mathrm{O}$ ambiente mais democrático implica estar aberto às críticas, aceitar a diversidade de pensamentos e ideias. As decisões participativas, ao mesmo tempo em que contribuem para que as decisões sejam melhores, por avaliar os diferentes pontos de vista, também exigem mais tempo, em razão da necessidade de escutar a defesa das diferentes ideias, na busca de pontos de convergência e do convencimento. Isso também conflita com o traço cultural brasileiro (gestão do tempo), que pode apresentar-se como um dificultador para a rapidez de resposta, em razão da dificuldade de cumprir horários, da falta de planejamento e da inclusão de conversas amistosas em reuniões. O ambiente democrático, sem dúvida, traz maior criticidade, competitividade e capacidade de inovação para as organizações. Os profissionais com competência política podem contribuir para que esse ambiente seja mais respeitoso e dinâmico. No entanto não basta ter o discurso democrático, é preciso criar um ambiente realmente propício ao debate, que não crie distorções. Nesta pesquisa, trabalhou-se com a ideia de que profissionais em cargos de gestão podem ser, ao mesmo tempo, bons líderes. E bons líderes, no contexto recente, implica uma postura menos autoritária e mais facilitadora e conciliadora em relação aos conflitos, às tomadas de decisão e às disputas nas organizações.

Com o intuito de responder à Proposição 3 - As características de uma boa reputação e atribuição de legitimidade podem ser associadas às características de líderes considerados competentes politicamente, empregaram-se os retornos referentes às questões 3,11 e 12 .

Tanto a reputação quanto a atribuição de legitimidade são construídos socialmente. A questão do resultado foi, recorrentemente, mencionada pelos gestores entrevistados como um fator fundamental para adquirir uma boa reputação, assim como o caráter e integridade. Esses aspectos corroboram o que a autora do presente estudo encontrou na literatura sobre o tema. O resultado foi considerado um fator básico para uma boa reputação, mas ele sozinho também não a garante. É preciso que o resultado 
seja sustentável, o que inclui um trabalho colaborativo, em que as relações e seus participantes sejam valorizados. Nesse sentido é que se defende aqui que a boa reputação tem uma relação direta com a competência política, na medida em que se podem associar algumas qualidades e características dos indivíduos com competência política àqueles que possuem uma boa reputação.

Para Zinko et al. (2012), a reputação é baseada em um conjunto de fatores que incluem o comportamento passado dos indivíduos, suas ações, assim como seu capital humano, suas habilidades sociais e sua competência política. Os indivíduos podem desenvolver sua reputação no trabalho principalmente em razão da sua capacidade de ter uma boa performance, por serem colaborativos e por ajudar os outros.

A questão da performance e da competência política foi estudada por Treadway et al. (2013). Segundo esses autores, a natureza tênue da relação performance/poder sugere a presença de variáveis moderadoras. Segundo eles, os profissionais com competência política são mais conscientes da sua performance e são habilidosos em apresentar e transmitir tal performance de uma maneira não ameaçadora e influente. Eles mostraram que os indivíduos com uma performance positiva tendem a ter maiores níveis de poder interpessoal se eles apresentam competência política.

A reputação de um líder é tipicamente associada à confiança (HALL et al., 2004). Profissionais competentes politicamente são vistos como pessoas que têm a intenção de reciprocidade e inspiram comprometimento e confiança (FERRIS et al., 2005). A rede de relacionamentos da qual um indivíduo faz parte pode ser uma fonte da sua boa reputação individual. A reputação de um líder é um produto e é também definida por suas relações sociais (GOULDNER, 1957). Uma das dimensões críticas da competência política é o networking, que é a habilidade de criar redes de relacionamento, fazer coalisões etc. E a dimensão sinceridade evidente que chama a atenção para a questão da confiança e do comportamento ético necessários para uma boa reputação.

Diferentes qualidades, recursos e características dos indivíduos contribuem para a reputação do líder e podem ser considerados como antecedentes da sua reputação. Essas qualidades podem ser divididas em três categorias: 1) capital humano; (2) capital social e (3) estilo de liderança. Tanto o capital social quanto o estilo de liderança são fortemente influenciados pela competência política da liderança. O capital social é baseado nos recursos individuais que um indivíduo adquire por conhecer outros e por sua identidade social que resulta em benefícios tangíveis. Já o estilo de liderança refere- 
se à maneira pela qual o comportamento é expresso, mais do que o comportamento em si. Ele reflete a inteligência, a personalidade e a competência social e política (HALL et al., 2004). Os líderes politicamente competentes são capazes de construir uma larga base social e um capital organizacional que acabam por expandir os recursos disponíveis aos seus liderados, aumentar o peso de suas recomendações em relação às indicações para promoções e proporcionar uma maior reputação organizacional ao seu grupo de liderados (RHOADES; EISENBERGER, 2002; FERRIS et al., 2003).

A reputação da liderança é uma identidade percebida que serve para reduzir a incerteza sobre a expectativa de um comportamento futuro do líder (AMMETER et al., 2002). A reputação é um termo associado a prestígio e status, os quais denotam uma visão positiva que qualificam o termo. A reputação é, sem dúvida, um diferencial na habilidade de influenciar outros (FERRIS et al., 2005). Após a análise dos dados obtidos, acredita-se ser possível associar algumas características de profissionais com boa reputação aos profissionais competentes politicamente. Isso porque o profissional competente politicamente transmite coerência e utiliza sua influência pessoal para obter recursos e oportunidades para seus liderados e para alcançar as metas do grupo.

Já a atribuição de legitimidade foi fortemente associada à questão do reconhecimento, o que corrobora a literatura sobre o tema e que define que a legitimidade de um líder refere-se ao nível em que outros acreditam que ele mereça gerir, ordenar e demandar suas ações e exercer influência. São conferidas ao líder pelos seus liderados uma aceitação voluntária e uma autoridade aprovada. A legitimidade implica qualidades como credibilidade, confiança e lealdade (HOLLANDER, 1993; CHOI; MAI-DALTON, 1999).

A legitimidade de um líder é baseada na sua competência, habilidade e comprometimento para alcançar as metas do grupo. Os indivíduos esperam um alto nível de performance de um líder legítimo. Por essas razões, acredita-se, neste estudo, que qualidades e características de líderes legítimos podem ser associadas aos profissionais vistos como competentes politicamente.

A literatura da psicologia sugere que a natureza do comportamento de resposta às desigualdades individuais ou de grupo em relação à distribuição de recursos e oportunidades será moldada pela visão da legitimidade ou não da autoridade. Diferenças na alocação de recursos e oportunidades não provocam raiva quando a autoridade ou a instituição é vista como legítima (TYLER, 1997). Um dos resultados da competência política da liderança é o suporte político da liderança aos liderados. Esse suporte é visto 
como uma forma de a liderança usar sua competência política para beneficiar seus liderados. Alguns exemplos de resultados positivos potenciais para os liderados são: aquisição de recursos; criação de oportunidades de desenvolvimento; restauração da justiça e remoção de obstáculos.

No presente estudo, utilizou-se a literatura sobre legitimidade baseada nos fundamentos da psicologia da legitimidade. Para os autores dessa área, as teorias de legitimidade devem considerar os aspectos relacionais, instrumentais e morais da legitimidade. Isso inclui questões como: 1) As pessoas são influenciadas por como são tratadas pelas autoridades; 2) Neutralidade das autoridades; 3) Benevolência ou confiabilidade dos seus motivos; 4) reconhecimento que trata do respeito interpessoal e da dignidade do tratamento interpessoal - preocupações relacionais (TYLER, 1989; TYLER; LIND, 1992). Essas questões estão fortemente ligadas às dimensões críticas da competência política e seus antecedentes como amabilidade, que é uma orientação interpessoal agradável e de afetividade positiva; conscienciosidade, que é a tendência a manter o foco para fora, em direção aos outros e mais no ambiente do que em si mesmo; estado de ação, que é a habilidade de regular de maneira apropriada suas ações, conseguindo filtrar impulsos competitivos. Os profissionais competentes politicamente são vistos como líderes competentes, que possuem um comportamento político justo. A competência política permite que o profissional gerencie os interesses divergentes de maneira que inspire consistência e positividade (BLICKLE et al., 2011; MUNYON et al., 2015). Um alto índice de competência política possibilita ao profissional exercer os dois papéis importantes para uma liderança legítima: a liderança de equipes, que engloba a valorização, o envolvimento e o respeito pelos membros da equipe e, ao mesmo tempo, que ele seja um bom gestor na "arena política", o que envolve a resolução de conflitos e o aumento da influência e aquisição de recursos e criação de oportunidades para a equipe.

Estudos mostram que a legitimidade de uma ampla variedade de autoridades sociais (legal, política, religiosa e administrativa) tem declinado nas décadas recentes. As lideranças atuais e futuras já não conseguem garantir sua legitimidade com base na autoridade concedida, pelo contrário, cada vez mais a conquista da legitimidade é um processo autêntico que demanda manutenção constante. A liderança baseada em premiação, coerção ou em ambos é frequentemente ineficiente. Quando consideradas legítimas, as lideranças conseguem ter mais liberdade para buscar políticas que sejam interessantes no longo prazo para o interesse do grupo (TYLER, 1990). Após a análise 
das respostas dos gestores, foi possível concluir que, no contexto das organizações e da sociedade atual, em razão das várias crises institucionais, a busca por líderes verdadeiramente legítimos têm aumentado. O líder legítimo é visto como aquele que não precisa se impor pela autoridade; pelo contrário, sua legitimidade ocorre pela aceitação natural da sua influência pelos demais membros da sociedade. Nesse sentido, o papel positivo do sistema de influência político parece ganhar maior importância ou até mesmo, em alguns casos, substituir o sistema de influência de autoridade. O sistema de influência político pode ter um papel extremamente positivo por possibilitar as mudanças e inovações necessárias na gestão e na sociedade atualmente.

Pode-se perceber que os construtos reputação e atribuição de legitimidade são muito importantes para a efetividade no ambiente organizacional. Esses construtos contribuem para o aumento da influência da liderança nesse ambiente. As dimensões da competência política parecem contribuir para a aquisição da reputação e atribuição de legitimidade. No entanto esses construtos (reputação, legitimidade e competência política) têm um caráter dinâmico e complexo e, portanto, a delimitação entre reputação e legitimidade e sua relação com a competência política não é clara, o que leva a concluir sobre a necessidade de um estudo mais aprofundado, que permita estabelecer relações estatísticas entre esses construtos de forma mais precisa.

A Proposição 4 lida com a seguinte questão: As organizações brasileiras e seus profissionais reconhecem a importância da competência política no desenvolvimento da carreira dos seus gestores. As respostas às perguntas 4, 6 e 8 da entrevista aberta foram utilizadas para responder a essa proposição.

As organizações brasileiras e os profissionais reconhecem a dimensão política e a importância da competência política no desenvolvimento de suas carreiras. Todos os entrevistados admitiram que essa competência foi fundamental para sua ascensão profissional, e a maioria disse, inclusive, que foi a competência mais importante. No entanto foi possível observar que não existem práticas para avaliar o perfil ou formas de selecionar e promover os profissionais com base especificamente nessa competência e, principalmente, oferecer os meios que proporcionem o seu desenvolvimento, seja por meio de exposição a situações que lhes permitam vivenciar a "arena política", seja por intermédio de treinamentos, mentoring ou coaching. Essa percepção se dá de maneira intuitiva; aqueles profissionais que percebem essa dimensão a utilizam para sua atuação e seu desenvolvimento na carreira. Todos os gestores apontaram sua preocupação com as competências políticas na contratação de profissionais para sua equipe, alegando que 
pessoas sem essa competência acabam trazendo problemas em razão das dificuldades de conciliação e resolução de conflitos. Ficou evidente também que, apesar de existirem treinamentos para liderança, negociação, entre outros, não existe um treinamento que trate dessas questões políticas diretamente. Essa é uma deficiência geral das organizações, e o motivo mais provável disso é o fato de a perspectiva política ainda ser um tabu, em razão da sua conotação negativa e por ser uma questão implícita nas relações dentro das organizações.

Nesse sentido, concorda-se, neste trabalho, com a afirmação de Ferris et al. (2007) de que as organizações deveriam explorar formas de treinar e desenvolver as competências políticas nos seus profissionais com bom potencial. A ideia de um profissional com bom potencial está relacionada com o exposto por Dutra (2010) de que alguns profissionais não se sentem à vontade para atuar na "arena política" das organizações. Por outro lado, algumas pessoas apresentam uma habilidade natural para perceber esse ambiente e atuar nele, portanto, as organizações devem buscar esse perfil para desenvolvê-lo. A competência política contribui para que os profissionais possam atuar tanto como bons gestores de "arenas políticas" quanto como líderes de equipe, ou seja, para que tenham o perfil ideal e mais completo para os cargos de liderança. Isso porque a competência política traz, em sua essência, a valorização e a sensibilidade para o outro, assim como a busca por resultados comuns, mediante um comportamento ético e coerente.

$\mathrm{Na}$ atualidade, as organizações do mundo, inclusive as brasileira estão cada vez mais buscando a transparência em seus processos. Essa transparência contribui para a instalação de políticas claras, processos mais democráticos e transparentes que, por sua vez, implicam lidar com questões mais subjetivas, com contradições, ambiguidades e emoções no ambiente organizacional. É fato que o desafio de lidar abertamente com a questão política é maior. É importante salientar que trabalhar em uma organização mais democrática, onde o aspecto político é explicitado exigirá de suas lideranças muito mais. No entanto saber lidar com as incertezas, ambiguidades e subjetividades do mundo contemporâneo é uma competência fundamental para as lideranças e para a sobrevivência e sucesso das organizações no contexto atual.

A competência política parece contribuir para essas expectativas na medida em que trata de um comportamento flexível, por meio da capacidade de adaptar o comportamento às diferentes situações sociais no ambiente organizacional e por envolver um comportamento ético e íntegro. A competência política é um construto 
complexo, dinâmico e que lida com a interdependência, as ambiguidades e os conflitos inerentes às interações humana. Essa é uma competência que está relacionada com o saber lidar com essas as ambiguidades, que estão atreladas a questões conflitantes como: interesses próprios e organizacionais, postura democrática e autoritária, emoção e razão, competência técnica e competência social, entre outras. O profissional competente politicamente, no entanto, sabe lidar com essas contradições se portando de maneira adequada, ou seja, ele sabe o momento correto e a medida certa de equilibrar essas questões conflitantes. O profissional competente politicamente consegue lidar com o que há de mais humano nas pessoas, seus valores, interesses, conflitos e emoções. Foi possível perceber pelas entrevistas que, à medida que os profissionais crescem e assumem cargos mais altos, a importância relativa dos conhecimentos técnicos diminui e a capacidade de suportar essas ambiguidades torna-se um diferencial para a efetividade na organização. Segundo Mintzberg (1985) a maioria das transições de poder ocorre de maneira conflituosa e envolve resistência, e normalmente é a política que serve de "lubrificante" para possibilitar sua movimentação. Nenhuma distribuição de poder na organização, seja ela conflituosa ou não, é completamente estável no longo prazo e está livre de ser desafiada.

Em seguida, apresentam-se algumas questões que não foram inseridas nas proposições, mas que, por estarem presentes na pesquisa, serão discutidas nessa conclusão.

Foi possível perceber que o tema "política nas organizações" é considerado um tabu. Os depoimentos a seguir corroboram a ideia de Pfeffer (1992), Bourdieu (1989), Lepisto e Pratt (2012) e Miranda (2009) de que existe uma dificuldade dos profissionais e das organizações em tratar das questões políticas, como foi possível verificar nas falas seguintes:

"Esse assunto acaba sendo um tabu. Não se fala sobre isso e poucos são aqueles desenvolvidos nessas habilidades. Não se fala em poder, mas se vê o jogo de poder presente em todas as decisões, em todas as relações. Quando acontecem mudanças como perdas de espaço de influência ou aprovação de valores mais volumosos para determinados setores, o perfil de comportamento dos grupos é impactado. O poder está presente em qualquer grupo, mas, teoricamente, quanto mais alto o nível dentro das organizações maior é o poder envolvido." (Profissiona1 3.1) 


\begin{abstract}
"Um ponto interessante é o reconhecimento de que nas organizações existe essa dimensão política. As pessoas não gostam de falar nesse assunto. No fundo é aquela falsa ideia de que as pessoas dentro da empresa são racionais, profissionais, mas elas continuam sendo pessoas. Ninguém abre um parêntese em sua vida e entra para trabalhar. As pessoas estão na empresa com todas as suas contradições, seus valores e tudo. E, como ser humano, ele está ali inteiro e, portanto, ele é um ser político. As organizações não explicitam isso. É uma coisa considerada desconfortável. As empresas não gostavam de lidar com isso porque pessoas são complicadas, complexas." (Profissional Experiente 3)
\end{abstract}

Os trechos acima mostram que a questão da política e do poder nas organizações é ainda considerado um tabu e que a maioria das organizações opta por negá-la. Nesta pesquisa, corroborando o pensamento de Pfeffer (1992), Bourdieu (1989) e Miranda (2009), defende-se a importância de estudar esse aspecto do ambiente organizacional, mas, principalmente, de explicitá-lo e tornar esse conhecimento acessível. Essas atividades são, muitas vezes, entendidas como atividades pouco transparentes porque somente alguns são conhecedores das regras do jogo. As falas a seguir demonstram o aspecto positivo da explicitação:

"O comportamento político disfuncional pode ser percebido em algumas situações sim, em outras ele fica velado ou aparece como uma teimosia. É complexo identificá-lo, pois ele está sempre travestido de algo mais. Talvez, se ele fosse explícito, seria mais fácil tratá-lo. É mais comum percebemos os sintomas e os indícios desse comportamento, mas a postura em si aparece com outro nome. Contudo, quando esse comportamento é explícito e contraria uma norma de conduta da organização, é possível reprimi-lo.” (Profissional 4.2)

"Se você assume explicitamente a dimensão política da organização, ela ganha um potencial imenso. Você tem uma bomba positiva na mão. Se você souber cooptar, no bom sentido, incluir, fazer com que as pessoas se motivem e se integrem naquele ambiente como pessoas, a produtividade será muito maior. Explicitar o caráter político de uma organização é absolutamente legítimo. É legítimo que um funcionário queira crescer profissionalmente, ser gerente. Atualmente, as empresas tentam aplicar o difícil conceito da carreira em "Y". O funcionário muito bom tecnicamente não precisa ser gerente. Ele pode ganhar até mais do que o gerente sem ser gestor. Dessa forma, é possível acomodar os conflitos, permitindo que as pessoas realizem atividades que se adéquem a seus perfis. 
Explicitar essa dimensão é saudável, ela é muito fecunda." (Profissional Experiente 3)

Miranda (2009), ao analisar os resultados de duas investigações que apresentaram as contradições em relação à visão sobre o comportamento político, afirma que o que ocorre é uma espécie de relação amor/ódio, em que os indivíduos estão cientes da sua existência e da sua importância, são participantes ativos no jogo político, mas, ao mesmo tempo, defendem a sua abolição, já que a atividade é entendida como pouco transparente e que só alguns são conhecedores das regras do jogo. Para Pfeffer (1992), negar a existência das questões política e de poder, o que inclui lidar com as questões inerentes aos sentimentos, valores e interesses humanos, deixa as pessoas mais susceptíveis aos apelos emocionais. E pessoas desprevenidas são mais facilmente afetadas. Um dos profissionais entrevistados na sugestão final da pesquisa falou sobre a questão velada da política nas organizações e sobre a dificuldade de lidar com esse aspecto de forma explícita:

"Eu acho que as empresas de mercado altamente competitivas não têm a capacidade de falar a verdade. Não é produtivo. Você perde tempo e tempo é dinheiro. E você gasta recursos. Você pode criar mais conflitos. A empresa não pode perder tempo porque você está sofrendo. Agora tem uma "moçada" que está chegando ao mercado que se preocupa mais com o cuidado com as pessoas. Eles estão mais próximos dos sentimentos. Eles são mais sinceros, não sei se é por conta da questão digital, que dá uma proteção, diminui o olho a olho, aí eu posso falar um pouco mais, ser mais sincero. O sentimento que vier depois da conversa tem um tempo de decantação, não tem o sangue quente da hora, aí os ânimos se acalmam. Está acontecendo uma transformação, essa nova geração é mais aberta, eu acredito que vai resolver melhor essa questão do velado. Eles são mais corajosos, o escrever para eles no meio digital não tem o mesmo peso que para a minha geração." (Profissional Experiente 4)

A explicitação do aspecto político das organizações facilita também o entendimento do papel da área de Recursos Humanos que, pela natureza da sua função, tenta, a todo o momento, conciliar os interesses pessoais e organizacionais e lida com as ambiguidades e contradições próprias do ser humano e deste na sua relação com o trabalho. A Gestão Estratégica de Recursos Humanos é uma das áreas mais políticas da organização, por ser responsável por distribuir os "recursos" mais importantes da 
empresa, ou seja, os "recursos" humanos que realmente são capazes de transformar a organização. Negar essa natureza política prejudica o entendimento de políticas e práticas adotadas pela organização na seleção, promoção e desenvolvimento de seus profissionais pela falta de clareza de critérios A conscientização sobre o sistema de influência político, a aceitação da sua realidade como um fato do seu dia a dia e a percepção da importância da competência política para os gestores podem contribuir para que as empresas e seus profissionais possam lidar melhor com algumas das contradições frequentes e adequar seus processos a essa realidade. A seguir, apresentam-se falas de profissionais sobre o papel político da área de Recursos Humanos:

"O RH representa a oportunidade de crescimento dentro das organizações. Quando é feita a avaliação de um executivo, o mapa de sucessão ou a estruturação da organização, lida-se com a vida profissional dos funcionários. Naturalmente, o RH é um espaço de poder no contexto organizacional, por essa função que é inerente à área." (Profissional 3.1)

"O RH tem um papel fundamental. Você precisa do apoio e da aprovação desse setor. Nas reuniões, é de extrema importância a presença do RH para que seus superiores saibam indiretamente que você está alinhado aos valores organizacionais e às melhores práticas. Isso é jogo político. Além disso, o $\mathrm{RH}$ é quem realiza os programas de avaliação comportamental. Essa área nos dá muitas ferramentas para fazer o profissional ter orgulho de pertencer à empresa. Portanto a política começa na seleção e perpassa a sua habilidade de lidar com essa estrutura paralela." (Profissional Experiente 4)

"O setor de Recursos Humanos tem o potencial de alavancar uma empresa. A área de Recursos Humanos também tem o papel de dar voz àqueles que não têm voz na direção da organização. Na mesa de negociação, eu representava não somente o lado da empresa, que estava implícito na minha função de gestora, mas também o de todos os empregados, principalmente os de níveis hierárquicos mais baixos." (Profissional Experiente 7)

Outra questão importante a ser discutida é que nem todos os profissionais se sentem motivados ou competentes para atuarem politicamente. A vontade política é um precedente fundamental para a avaliação dos profissionais. As organizações devem ficar atentas ao perfil dos profissionais e sua adequação para atuação nos cargos de gestão em 
que é necessária a atuação na "arena política", a fim de evitar a insatisfação, a frustração e o conflito entre os objetivos pessoais e os da organização. Um requisito para atuar na "arena política" é, sem dúvida, ter vontade política para que essa competência possa ser desenvolvida, e isso deve ser levado em consideração. Caso contrário, as organizações continuarão a perder bons técnicos e ganharão péssimos gestores. A atuação na "arena política" depende de vontade e competência política. Há profissionais que não se sentem confortáveis ou motivados a atuarem politicamente, ao "jogá-los" nessa arena, a empresa poderá expô-los a situações com as quais eles não sabem e não querem lidar, podendo causar traumas e prejuízos para todos os envolvidos. Por essa razão, a conscientização sobre a função política dos gestores permite à área de Gestão Estratégica de Recursos Humanos uma maior adequação na estruturação das carreiras que considere os diferentes perfis de profissionais. A atuação inadequada de um gestor pode trazer prejuízos financeiros para as empresas e psicológicos para seus profissionais, conforme relata o trecho a seguir:

"No Brasil, não há muita escolha. O funcionário, para atingir o reconhecimento profissional e financeiro, acaba seguindo a carreira gerencial de coordenador, supervisor, diretor, etc. Apenas em ramos muito específicos da indústria, como a farmacêutica e a de cosméticos, adotam o conceito de carreira em Y. Contudo elas são uma exceção. Isso faz com que excelentes técnicos, que não têm habilidade e vontade de gerir pessoas, assumam cargos de gestão para crescer na empresa, causando um cenário caótico na organização." (Profissional experiente 10)

"Essa noção, muito presente na sociedade, de que para ser bem sucedido é preciso tornar-se diretor ou presidente nem sempre é verdadeira. Para alguns, ter sucesso é ter poder, dinheiro etc. $\mathrm{O}$ sucesso, contudo, não é medido apenas por um pilar da existência humana, que é o trabalho. Esse é apenas um deles. Há muitos outros pilares que são fundamentais para que esse profissional como pessoa se sinta vencedor. Essa medida de sucesso é individual." (Profissional 3.1)

A volta do interesse e de estudos do poder e política nas organizações em razão das mudanças no ambiente organizacional faz refletir sobre uma nova perspectiva em relação a esses conceitos, o que poderia implicar até mesmo a consideração de que talvez o que esteja presente é um jogo que é jogado de modo diferente. Isso porque as regras para aquisição de poder mudaram, a autoridade formal não garante poder, a 
informação e o conhecimento passaram a ser uma das principais formas de poder, e ele está, mesmo que de maneira desigual, ao alcance de todos, até mesmo de jovens que acabaram de entrar na empresa. Essas mudanças mostram algumas alterações na forma de obtenção e manutenção do poder. Foi possível perceber neste estudo que o papel positivo do sistema de influência político é mais provavelmente encontrado em cenários mais democráticos e em ambientes de mudança e que, quanto mais alto os cargos, maiores e mais complexas as necessidades da competência política. A coerência, a ética e a integridade foram apontadas recorrentemente como aspectos fundamentais para o uso e a efetividade da competência política. Essa dimensão da competência política reforça o seu aspecto positivo e legítimo, uma vez que a obtenção de poder e influência por meio do autoritarismo já não representa a única forma socialmente aceitável.

Os estudos sobre competência política e a importância do seu papel na efetividade das lideranças ganham maior aceitação e força à medida que sua perspectiva positiva é explicitada. A competência política é uma ferramenta de influência baseada nos conceitos da ética, confiança e verdade. A desmistificação da exclusividade do aspecto negativo do comportamento político traz o entendimento de que os interesses pessoais e organizacionais não são mutualmente excludentes e também de que as pessoas se engajam em comportamentos políticos não apenas para o benefício próprio ou material. Os estudos mostram que a competência política é, na verdade, uma habilidade relacionada à efetividade social cuja motivação está alinhada a um objetivo organizacional. As organizações tendem a recompensar os atos que atendam a suas expectativas e objetivos. Os interesses pessoais podem ser alinhados aos organizacionais, o que pode ser desde ajudar a equipe a superar obstáculos até a autopromoção, no entanto sua valorização dependerá do comprimento do objetivo maior, ou seja, o alinhamento ao objetivo da organização. As teorias sociais mostram que o processo de influência pode ser empregado por várias razões e serve para atingir múltiplas metas, por exemplo, para conduzir as pessoas de hábitos negativos para direções positivas, entre outras motivações que acabam criando condições para novas oportunidades de mudança, para construir e manter relacionamentos e para gerir o autoconceito. Alguns autores acreditam que a conciliação de interesses próprios e organizacionais passa, primeiramente, por admitir a questão humana das organizações, ou seja, que os interesse colocados nesse contexto nada mais são que interesses de indivíduos e não da organização. Portanto o importante é compreender a extensão em que os interesses pessoais podem ser visto como legítimos ou consistentes com os 
objetivos e metas organizacionais (PFEFFER, 1992; KATZ; KAHN, 1978; FEDOR et al., 2008).

Aceitar a visão neutra sobre o comportamento político parece ser a maneira mais madura de encarar essa realidade nas organizações A realidade da vida nas organizações é diferente daquela dos contos infantis em que a dicotomia do bem e do mal, do herói e do vilão prevalece. As organizações são compostas por pessoas gerindo pessoas. Profissionais podem errar querendo acertar e vice-versa. Prever o resultado de suas ações no longo prazo pode ser uma tarefa difícil. No entanto é preciso que tanto as organizações como os profissionais busquem a conciliação de seus interesses, ideologias, valores éticos, para um bem maior. A função social da empresa e do trabalho para os indivíduos é que permite que grandes mudanças, evoluções e melhorias possam ocorrer na sociedade. Aceitar a perspectiva positiva do comportamento político é também saber lidar com o lado mais humano dos indivíduos que têm emoções, interesses e expectativas. A arte da influência é um bem necessário aos profissionais éticos e bem intencionados. A esperança é que as pessoas com boas intenções saibam jogar o "jogo", que saibam usar suas competências políticas para influenciar e alcançar objetivos para o bem maior da sociedade. A esperança é que esses profissionais sejam valorizados de maneira que o "jogo" ético e moral prevaleça nas organizações e seja incentivado, enquanto o "jogo" disfuncional seja punido e inibido. A esperança é que as organizações privadas sejam dominadas pela ética a ponto de influenciar e exigir a mesma postura na esfera pública.

\subsection{Contribuições da pesquisa}

Pesquisar e discutir um tema pouco explorado na literatura nacional é, sem dúvida, um grande desafio. Um desafio que envolveu dificuldades desde a delimitação do tema e que, por isso, levaram a pesquisadora a mudar o caminho algumas vezes. Outro grande desafio foi a tentativa de trazer parte do que já fora estudado sobre o tema na literatura internacional para o presente momento e, ao mesmo tempo, buscar compreender como a temática é vista e sentida na cultura brasileira. Em razão da consciência das dificuldades e das limitações envolvidas em um estudo como este, classifica-se esta pesquisa como um trabalho introdutório sobre o tema, que não teve nenhuma pretensão de fazer generalizações, mas sim de tentar diagnosticar uma 
realidade que possibilitasse refletir sobre a temática, iniciar uma linha de pesquisa e apontar algumas das necessidades de estudos futuros. Acredita-se que esta pesquisa contribui para a esfera acadêmica ao abrir o espaço para uma linha de pesquisa ainda não explorada, ao trazer a perspectiva política e positiva sobre o comportamento político nas organizações e na carreira das lideranças. Quer-se crer que esta pesquisa permite reflexões acerca da democratização do ambiente organizacional, da estruturação do poder, do papel estratégico da área de gestão de pessoas, da aderência desse conceito à cultura nacional, entre outras questões. Outra contribuição deste trabalho foi oferecer um instrumento validado e traduzido para o português para medição da competência política, que, atualmente, é uma competência muito importante para as organizações.

\subsection{Limitações da pesquisa}

Esta pesquisa utilizou-se de métodos mistos de pesquisa. Na primeira etapa, utilizou-se um número de dados válidos considerados adequados (200 pessoas) para a validação de um questionário com um total de 18 questões. Na segunda etapa, que foi qualitativa, entrevistou-se um total de 21 profissionais. Esse número de entrevistados também é considerado adequado ao método qualitativo e ao seu propósito de aprofundar o estudo das questões e a compreensão do significado que a temática tem para as pessoas. Mesmo sendo adequada às especificidades de cada método, não é possível chegar a conclusões definitivas, isso porque o tema é complexo e, sem dúvida, carece de novos estudos. Portanto este estudo, em seu caráter exploratório, permite apenas apontar direções e indicações para futuros estudos.

Outra limitação deste estudo está relacionada à amostra, uma vez que a localização dos profissionais entrevistados limitou-se às regiões Sudeste e Centro-Oeste do país. Apesar de serem profissionais que representam parte da realidade do país e da sua cultura, a amostra não cobriu todas as regiões e suas peculiaridades.

Uma das vantagens de utilizar como respondentes um grupo de profissionais mais experientes, de diferentes áreas e que, em sua maioria, não estava inserido no mercado de trabalho é que isso permitiu escutar relatos de profissionais com uma sólida experiência e liberdade para dar informações, por não manterem vínculos com nenhuma organização. Por outro lado, uma possível desvantagem desse grupo é o fato de que alguns desses profissionais já se encontram fora do mercado de trabalho e, em razão da dinâmica do mercado, algumas questões de contexto e estruturação podem ter se 
alterado no ambiente organizacional. Alguns desses profissionais, inclusive, comentaram que, na sua percepção, o ambiente organizacional tem sofrido mudanças e que a questão da influência e política tem se tornado ainda mais importante. No entanto as entrevistas realizadas nos estudos de caso com profissionais do mercado amenizam esta possível limitação.

Os construtos reputação e legitimidade baseiam-se em uma construção social que, em alguns momentos, apresentaram características similares. Faz-se necessária uma análise mais profunda, que inclua estatísticas mais elaboradas, a fim de verificar questões como validade discriminante, confiabilidade, entre outras.

\subsection{Futuros estudos}

É, sem dúvida, um grande desafio lidar com um construto tão complexo como a competência política, em razão dos diferentes fatores que afetam o seu entendimento, como a influência do ambiente, das características pessoais, da percepção das pessoas em relação à intenção dos atores e dos resultados das atitudes. Nesta pesquisa, tentou-se apresentar alguns dos estudos existentes na área, assim como identificar como a perspectiva política nas organizações e na carreira das lideranças é percebida no cenário nacional. Todavia esta pesquisadora tem a consciência de que muito trabalho e pesquisa ainda são necessários para a melhor compreensão de toda essa complexidade. Desse esforço surgiram ideias de possíveis caminhos para ampliar as pesquisas na área. Para tanto, em seguida, são dadas sugestões para futuros estudos.

Um ponto que pode ser mais bem explorado é a relevância de cada dimensão crítica (Astúcia social, influência interpessoal, habilidade de network e sinceridade evidente) da competência política para os resultados organizacionais. Existem dimensões que são mais relevantes do que outras? Existem dimensões que afetam mais significativamente um determinado resultado? A identificação do peso de cada dimensão para um resultado determinado pode contribuir para sua compreensão e até mesmo para o melhor enfoque dos treinamentos e desenvolvimento dos profissionais.

Há uma questão geracional que precisa ser investigada. Alguns relatos dos entrevistados mostraram um comportamento distinto por parte dos profissionais mais jovens, seja por meio de atitudes mais explícitas em relação à sua intenção e seu desejo de ascender na carreira, seja por uma maior desconfiança ou um descrédito em relação às instituições e autoridades formais, o que faz com que esses profissionais jovens 
rompam barreiras hierárquicas, gerando comportamentos mais informais e até mesmo um sentimento de igualdade com seus superiores. Essa forma mais explícita de tratar um tema legítimo como o crescimento profissional e uma crença de ser uma "voz" que tem direito e merece ser escutada levam a crer que pode haver diferenças ou até mesmo mudanças no comportamento político entre as diferentes gerações. As passagens a seguir exemplificam essa questão:

"A minha geração se convencia muito pelo discurso. Hoje, é muito evidente a coerência entre o discurso e a prática. A geração mais jovem é muito sensível a isso. Os jovens avaliam constantemente se as falas e os atos estão caminhando juntos." (Profissional 4.2)

"Eu observo uma nova geração muito despreparada chegando às empresas. Essa é uma geração que nunca viveu crises, o que torna o cenário político da organização ainda mais crítico. É uma geração educada para ter sucesso, que não sabe lidar com a decepção.” (Profissional Experiente 10)

Outro aspecto que carece de investigações futuras é a questão do gênero. Nesta pesquisa, duas das apenas três mulheres entrevistadas relataram desconforto em relação às disputas políticas. Estudos anteriores em outros países foram realizados sobre essa questão, e os resultados apresentaram diferenças entre os gêneros. Esse aspecto não foi explorado neste estudo, no contexto nacional.

Nesta pesquisa, identificou-se que a influência social e política existe em todos os níveis e nos diferentes cargos da organização. No entanto, corroborando a ideia de Dutra (2015), as atividades políticas nos níveis tático e estratégico apresentam-se de maneira distinta. À medida que o nível hierárquico aumenta, as atividades políticas se tornam mais complexas e até mesmo mais necessárias. Acredita-se na importância de aprofundar os estudos sobre as diferenças no grau de complexidade da competência política nos diferentes níveis da organização. Outro ponto identificado que necessita de mais estudos e que afeta o uso da competência política está relacionado ao tamanho da empresa, ao tipo de atividade e à estrutura da empresa. Em empresas de pequeno porte, por exemplo, comandadas por seus proprietários, muitas vezes, o sistema de influência que prevalece é o de autoridade, pois se realiza a vontade do dono, portanto existe pouco espaço para a influência política, que é a que permite que as várias “vozes"sejam ouvidas. 
As pesquisas realizadas por Ferris et al. (2000, 2005), que constituem o grupo que atualmente mais tem realizado pesquisas empíricas sobre o tema, tratam da competência política nas interações com subordinados, pares, superiores, fornecedores e clientes. Identificou-se uma lacuna nas pesquisas desses autores que merece estudos futuros, uma vez que pouco se discute nelas sobre a relação das lideranças com os conselhos de administração, grupo de sócios e proprietários, que, igualmente, representam uma demanda real e complexa de competência política e que também não foi explorada nesse estudo. São "arenas políticas" importantes para o desenvolvimento da carreira dos altos executivos. Nas notas de campo, esse aspecto foi mencionado por um dos entrevistados, conforme se segue:

"É preciso pensar em como lidar com os diferentes stakeholders. É preciso que o líder se encaixe, saiba lidar com os conselhos de administração, grupos de investidores etc. As empresas são compostas por esses grupos distintos de interesses diferentes. Isso acaba exigindo muito mais competência política dos líderes. Esses grupos são importantes, você tem que lidar com interesses e ideologias. Esse jogo para cima é complicado. Ele é mais difícil que esse jogo para baixo. Esse jogo para cima, por exemplo, eu não aprendi a jogar. É um jogo bruto. Quando eu caí em uma empresa com muitos acionistas, eu demorei a entender esse jogo. E ele influencia para baixo. Na empresa familiar, é comum também a administração de dois irmãos, por exemplo, você acaba se alinhando a um deles depois ele cai e você dança." (Profissional Experiente 2)

$\mathrm{Na}$ mesma linha de pensamento sobre a maior complexidade dos relacionamentos nos altos níveis da organização, o que inclui conselhos de administração, acionistas e proprietários, obtiveram-se alguns depoimentos que insinuaram alguns episódios muitas vezes difíceis de serem interpretados ou até mesmo situações que foram colocadas de forma proposital pelos superiores por intermédio de outros profissionais.

"Os subordinados têm mais facilidade para perceber o comportamento político disfuncional. Às vezes, eu me questiono por que os superiores têm mais dificuldade para perceber esse comportamento ou se eles percebem, se isso é proposital." (Profissional 2.1) 
"Você precisa decodificar exatamente o que uma pessoa está querendo dizer por trás de suas palavras. Você percebe direitinho que aquilo é armadilha. É interessante porque, algumas vezes, os pares conseguem ver claramente essa "segunda" intenção, mas os superiores não conseguem. Você precisa compreender também que o seu superior tem mais informações que você. Eu sempre dizia aos meus funcionários que o que me diferenciava deles era a quantidade de informação. Eu tinha informações sobre eles e eles não tinham informações sobre mim. Então, sempre que ocorrem essas situações em que o superior parece não perceber um comportamento disfuncional, temos que lembrar de que ele tem informações sobre essa pessoa que nós não temos. Essa pessoa não é; ela parece. Pode ter alguma outra coisa atrás da armadilha." (Profissional Experiente 4)

"Eu vivi alguns conflitos acirrados que eu nunca consegui resolver com o departamento financeiro. Eu precisava de certas informações e eles não me davam. Às vezes, nós só entendemos o que está acontecendo muito mais tarde. Depois eu entendi que o conflito não se resolvia porque era ordem do presidente não me passar essa informação." (Profissional Experiente 5)

Outro ponto que merece estudos futuros está relacionado ao papel dos conselhos de ética e ouvidorias internas para tratar dos comportamentos políticos disfuncionais nas organizações. Nesta pesquisa, focalizou-se a perspectiva política do comportamento nas organizações, trabalhando com um conceito de política que é neutro. Apesar da ênfase dada ao seu aspecto positivo, em momento algum, negou-se a existência do comportamento político disfuncional. Entende-se inclusive que a melhor forma de criar um ambiente propício ao comportamento político funcional é reprimir o comportamento político disfuncional. Muitas organizações tratam essas questões por meio de departamentos específicos. Portanto acredita-se que pesquisas futuras devem ser realizadas para avaliar a atuação desses departamentos e os resultados dessa atuação na inibição do comportamento político disfuncional, ou seja, se a existência desses departamentos consegue reduzir o número de ocorrências e, ao mesmo tempo, contribuir para a formação de uma cultura favorável ao comportamento ético e funcional.

“A empresa precisa ser coerente com o seu código de ética, instrumento cuja função, por excelência, é pautar o relacionamento político funcional. A ouvidoria é um órgão muito importante na organização. A mediação também pode ser 
uma boa estratégia para resolver conflitos interpessoais e para evitar comportamentos disfuncionais." (Profissional 3.2)

"Nesse contexto de movimento ético, acho que seria importante avaliar o papel dos comitês de ética na contribuição da concepção funcional da política nas organizações." (Profissional Experiente 4)

"Existem áreas específicas que tratam da ética e da disciplina da conduta. O comportamento disfuncional, ou seja, que está fora do que a organização prescreve, é tratado por departamentos que vão analisá-lo e julgá-lo, emitindo uma sanção de acordo com seu grau de gravidade; podendo até gerar uma demissão. No caso dos conflitos interpessoais, temos uma ouvidoria interna para analisá-los. Mediadores formados, com capacitação para isso atuam in loco. A ouvidoria garante o anonimato do funcionário, e pode ser acionada por telefone ou por e-mail." (Profissional 4.2)

Outro ponto que carece de estudos futuros e reflexões é o papel da Academia que, por meio das instituições de ensino, pode contribuir para o desenvolvimento de competências políticas dos seus estudantes e incentivá-las, pela realização de trabalhos em grupo e discussões sobre conduta ética, democrática, que respeite as diferenças, mas, principalmente, pela aceitação de posturas e ideologias divergentes.

"As universidades também negligenciam o aspecto político. Saber conviver, comunicar e trabalhar em grupo são habilidades essenciais no mundo atual em que as pessoas estão constantemente conectadas. Ninguém constrói mais nada sozinho." (Profissional Experiente 10)

Como foi possível perceber ainda são necessárias muitas pesquisas sobre o Tema para sua compreensão mais ampla. A competência política é um construto importante para as organizações da atualidade e em razão da sua complexidade há muito o que ser estudado e descoberto. 


\section{REFERÊNCIAS}

AHRNE, G. Agency and Organization Towards an Organizational Theory of Society. Universidade de Michigan: Sage, 1990.

AHEARN, K. K. et al. Leader political skill and team performance. Journal of Management, v. 30, n. 3, p. 309-327, 2004.

ALLEN, R. W. et al. Organizational politics: Tactics and characteristics of its actors. California Management Review, v. 22, n. 1, p. 77, 1979.

AMMETER, A. P. et al. Toward a political theory of leadership. The Leadership Quarterly, v. 13, n. 6, p. 751-796, 2002.

AMMETER, A. P. et al. Introduction to: The Leadership Quarterly special issue on political perspective in leadership. The Leadershio Quarterly, v. 15, n. 4, p. 433-435, Aug. 2004.

ARENDT, H. A condição humana. Tradução de Roberto Raposo. 10 ed. Rio de Janeiro: Forense Universitária, 2004.

ARISTÓTELES. A política. São Paulo: Folha de S.Paulo, 2010. (Coleção Folha: Livros que mudaram o mundo, v. 11).

ATINC, G. et al. Perceptions of organizational politics: A meta-analysis of theoretical antecedents. Journal of Managerial, v. 22, n. 4, p. 494-513, Winter 2010.

AVOLIO, B. J.; BASS, B. M. Individual consideration viewed at multiple levels of analysis: A multi-level framework for examining the diffusion of transformational leadership. The Leadership Quarterly, v. 6, n. 2, p. 199-218, 1995.

BACHARACH, S. B.; LAWLER, E. J. Power and politics in organizations. San Francisco: Jossey-Bass, 1980.

BACHRACH, P.; BARATZ, M. S. Poder e decisão. In: CARDOSO, F. H.; MARTINS, C. E. (Orgs.) Política \& Sociedade. Rio de Janeiro: Companhia Editora Nacional, 1983. p.43-52.

BADER, G. E. Good guys finish last: understanding organizational politics. The Health Care Manager, v. 10, n. 1, p. 23-26, 1991.

BARBUTO JR., J. E.; SCHOLL, R. W. Motivation sources inventory: Development and validation of new scales to measure an integrative taxonomy of motivation. Psychological Reports, v. 82, n. 3, p. 1011-1022, 1998.

BARDIN, L. Análise de conteúdo. Lisboa: Edições 70, 1977.

BARNEY, J. Firm resources and sustained competitive advantage. Journal of Management, v. 17, n. 1, p. 99-120, 1991. 
BASS, B. M. The Bass handbook of leadership. Theory, research and managerial applications, v. 4, 2008.

BEDI, A.; SKOWRONSKI, M. Political skill at work: good or bad? Understanding its predictors and consequences. SAM Advanced Management Journal, v. 79, n. 2, p. 39, 2014.

BEN-YOAV, O.; HOLLANDER, E. P.; CARNEVALE, P. J. D. Leader legitimacy, leader-follower interaction, and followers' ratings of the leader. The Journal of social psychology, v. 121, n. 1, p. 111-115, 1983.

BENNIS, W.; NANUS, B. The strategies for taking charge. Leaders. New York: Harper Row, 1985.

BLAU, P. M. Exchange and power in social life. Piscataway, NJ: Transaction Publishers, 1964.

BLICKLE, G.; OERDER, K.; SUMMERS, J. K. The impact of political skill on career success of employees' representatives. Journal of Vocational Behavior, v. 77, n. 3, p. 383-390, 2010.

BLICKLE, G. et al. A Predictive Investigation of Reputation as Mediator of the Political Skill/Career Success Relationship 1. Journal of Applied Social Psychology, v. 41, n. 12, p. 3026-3048, $2011 \mathrm{a}$.

BLICKLE, G. et al. Role of Political Skill in Job Performance Prediction Beyond General Mental Ability and Personality in Cross Sectional and Predictive Studies 1. Journal of Applied Social Psychology, v. 41, n. 2, p. 488-514, 2011 b.

BOBBIO, N. Dicionário de política por Norberto Bobbio, Nicola Matteucci e Gianfranco Pasquino. Tradução de João Ferreira, Carmem Varriale e outros. Brasília: UnB, 1986.

BOBBIO, N. Ensaios sobre ciência política na Itália. Brasília: Editora UnB, 2002.

BOCK, A. M. B; FURTADO, O.; TEIXEIRA, M. de L. T. Psicologias. São Paulo: Saraiva, 1999. v. 13.

BORGATTI, S. P.; FOSTER, P. C. The network paradigm in organizational research: A review and typology. Journal of Management, v. 29, n. 6, p. 991-1013, 2003.

BORMAN, W. C. et al. Current directions and issues in personnel selection and classification. Research in Personnel and Human Resources Management, v. 22, p. 287-356, 2003.

BOUlTER, N.; DALZIEL, M.; HILL, J. (Ed.). People and competencies: the route to competitive advantage. London: Kogan Page, 1996.

BOURDIEU, Pierre. O poder simbólico. Tradução de Fernando Tomaz. Rio de Janeiro: Bertrand Brasil, 1989. 
BOURDIEU, Pierre. Razões práticas: sobre a teoria da ação. Campinas, SP: Papirus Editora, 1996.

BOURDIEU, Pierre; ZANOTTI-KARP, Angela. Structuralism and theory of sociological knowledge. Social Research, p. 681-706, 1968.

BOXALL, P. The Strategic Hrm Debate and the Resource Based View of the Firm. Human Resource Management Journal, v. 6, n. 3, p. 59-75, 1996.

BUCHANAN, D. A. You stab my back, I'll stab yours: management experience and perceptions of organization political behaviour. British Journal of Management, v. 19, n. 1, p. 49-64, 2008.

BUCHANAN, D.; BADHAM, R. Power, Politics, and Organizational Change: Winning the Turf Game. London: Sage, 2008.

BUCHANAN, D.; BADHAM, R. Politics and organizational change: The lived experience. Human Relations, v. 52, n. 5, p. 609-629, 1999.

BURNS, T. Micropolitics: Mechanisms of institutional change. Administrative Science Quarterly, v. 6, n. 3, p. 257-281, 1961.

BURT, R. S. The network structure of social capital. Research in Organizational Behavior, v. 22, p. 345-423, 2000.

BURT, R. S. The contingent value of social capital. Administrative Science Quarterly, v. 42, n. 2, p. 339-365, 1997.

CABRAL-CARDOSO, C. A utilização simbólica e política de informação técnica: estudo de processos de decisão em I\&D. Comportamento Organizacional e Gestão, v. 1, n. 1, p. 77-90, 1995.

CALDAS, M. P. Santo de casa não faz milagre: condicionantes nacionais e implicações organizacionais da fixação brasileira pela figura do "estrangeiro". In: MOTTA, F. P.; $C A L D A S$, M. P. (Org.). Cultura organizacional e cultura brasileira. São Paulo: Atlas, 1997. p. 73-93.

CARVALHO, C. A.; VIEIRA, M. F. O poder nas organizações. São Paulo: Thomson Learning, 2007.

CASCIO, W. F. Managing Human Resources: Productivity, Quality of Work Life, Profits. İstanbul: Literatür Yayıncılık, 1995.

CASTOR, Belmiro Valverde Jobim. O Brasil não é para amadores: estado, governo e burocracia na terra do jeitinho. Travessa dos Editores, 2004.

CHAKRAVARTHY, B. S. Managing corporate transformation: two contrasting leadership styles. In: THOMAS, H., O'Neal, D.; GHERTMAN, M. (Eds.). Strategy, Structure and Style. Chichester: John Wiley, 1997. p. 69-84. 
CHANDLER, H. M. The game production handbook. Sudbury, Massachusetts: Jones \& Bartlett Publishers, 2009.

CHANG, C. H.; ROSEN, C. C.; LEVY, Paul E. The relationship between perceptions of organizational politics and employee attitudes, strain, and behavior: a meta-analytic examination. Academy of Management Journal, v. 52, n. 4, p. 779-801, 2009.

CHAO, G. T. et al. Organizational socialization: Its content and consequences. Journal of Applied Psychology, v. 79, n. 5, p. 730, 1994.

CHARAN, R., DROTTER, S.; NOEL, J. Pipeline de liderança: o desenvolvimento de líderes como diferencial competitivo. São Paulo: Elsevier Brasil, 2010.

CHARAN, R O líder criador de líderes. São Paulo: Elsevier Brasil, 2008.

CHOI, Y.; MAI-DALTON, R. R. The model of followers' responses to self-sacrificial leadership: An empirical test. The Leadership Quarterly, v. 10, n. 3, p. 397-421, 1999.

CHU, R. A.; WOOD JR, T.. Cultura organizacional brasileira pós-globalização: global ou local. Revista de Administração Pública, v. 42, n. 5, p. 969-991, 2008.

CIALDINI, R. B.; TROST, M. R. Social influence: social norms, conformity and compliance. In: Gilbert, D. T.; FISKE, S. T.; GARDNER, L. The Handbook of Social Psychology. New York, NY, US: McGraw-Hill, 1998. p. 151-192.

CLAUSSEN, J. G. T. et al. Talent management and career development: What it takes to get promoted. Journal of World Business, v. 49, n. 2, p. 236-244, 2014,

CLAUSSEN, J.; FALCK, O.; GROHSJEAN, T. The strength of direct ties: evidence from the eletronic game industry. International Journal of Industrial Organization, v. 30, n. 2, p. 223-230, 2012.

CLEGG, Stewart. Organization and control. Administrative Science Quarterly, v. 26, n. 4 , p. 545-562,1981.

CLEGG, S.; DUNKERLEY, D. Organization, class and control. New York: Taylor \& Francis, 1980.

CLEGG, S. R.; HARDY, C.; NORD, W. R. Handbook of organization studies. London: Sage Publications Ltd, 1996.

CODA, R. Learning how to manage human assets based on skills and competences: lessons from the Brazilian electrical sector. São Paulo: FEA/USP, 1999.

COFF, R. W. Human capital, shared expertise, and the likelihood of impasse in corporate acquisitions. Journal of Management, v. 28, n. 1, p. 107-128, 2002.

COLLINS, R. The credential society: An historical sociology of education and stratification. New York: Academic Press, 1979. 
CONSTANTINO, D. Psicologia positive e psicoterapia. In: IV CONGRESSO DE PSICOLOGIA DA UNIFIL, I CONGRESSO NACIONAL DE PSICOLOGIA, 2011. Anais... Londrina: EdUnifil, 2011.

CORTELLA, M. S.; MUSSAK, E. Liderança em foco. Campinas, S.P.: Papirus 7 Mares, 2009.

CRAWFORD, R. Na era do capital humano. São Paulo: Atlas, 1994. v. 1004.

CRESWELL, J. W. Projeto de pesquisa métodos qualitativo, quantitativo e misto. Tradução de Magda Lopes. 3. ed. Porto Alegre: Artmed, 2010.

CRESWELL, J. W.; CLARK, V. L. P. Designing and conducting mixed methods research. Thousand Oaks, Calif: Sage Publications, 2007.

CROOK, T. R. et al. Does human capital matter? A meta-analysis of the relationship between human capital and firm performance. Journal of Applied Psychology, v. 96, n. 3, p. 443, 2011.

CROPANZANO, R.; MITCHELL, M. S. Social exchange theory: An interdisciplinary review. Journal of Management, v. 31, n. 6, p. 874-900, 2005.

CROPANZANO, R. et al. The relationship of organizational politics and support to work behaviors, attitudes, and stress. Journal of Organizational Behavior, v. 18, n. 2, p. 159-180, 1997.

CROZIER, M. The problem of power. Social Research, v. 40, n. 2, p. 211-228, Summer 1973.

CROZIER, M. The Bureaucratic Phenomenon. Chicago: University of Chicago, 1964.

CROZIER, M.; FRIEDBERG, E. Actors and systems: The politics of collective action. Chicago: University of Chicago Press, 1980.

CYERT, R. M.; JAMES, G. M. A behavorial theory of the firm. Englewood Cliffs, NJ: Prentice-Hall, 1963.

DAFT, R. L.; LEWIN, A. Y. Where are the theories for the" new" organizational forms? An editorial essay. Organization Science, v. 4, n. 4, p. i-vi, 1993.

DAMATTA, R. A casa e a rua. Espaço, cidadania, mulher e morte no Brasil. São Paulo: Editora Brasiliense, 1985.

DAVIS, W. D.; GARDNER, W. L. Perceptions of politics and organizational cynicism: An attributional and leader-member exchange perspective. The Leadership Quarterly, v. 15, n. 4, p. 439-465, 2004. 
DELFINO, I. A.; SILVA, A. B.; ROHDE, L. R. A produção acadêmica sobre liderança no Brasil: uma análise bibliométrica dos artigos publicados em eventos e periódicos entre 1995 e 2009. In: ENCONTRO DA ASSOCIAÇÃO NACIONAL DE PÓSGRADUAÇÃO E PESQUISA EM ADMINISTRAÇÃO, 34, 2010. Anais... Rio de Janeiro: ANPAD, 2010.

DELUCA, J. R. Political savvy: Systematic approaches to leadership behind-thescenes. Berwyn, Pa: Evergreen Business Group, 1999.

DENZIN, N. K.; LINCOLN, Y. S. Handbook of qualitative research. Thousand Oaks, California: Sage publications, 1994.

DIMAGGIO, P. Cultural capital and school success: The impact of status culture participation on the grades of US high school students. American Sociological Review, v. 42, n. 2, p. 189-201, Apr. 1982.

DIPBOYE, R. L.; FOSTER, J. B. Multi-level theorizing about perceptions of organizational politics. In: YAMMARINO, F. J.; DANSEREAU, F. (Eds.)The many faces of multi-level issues. Stamford, CT: Emerald Group Publishing Limited, 2002. p. 255-270.

DOMHOFF, G. W. The Bohemian Grove and other retreats. A Study in Ruling Class Cohesiveness. New York: Harper \& Row, 1974.

DOUGLAS, C.; AMMETER, A. P. An examination of leader political skill and its effect on ratings of leader effectiveness. The Leadership Quarterly, v. 15, n. 4, p. 537-550, 2004.

DRORY, A.; ROMM, T. The definition of organizational politics: A review. Human Relations, v. 43, n. 11, p. 1133-1154, 1990.

DROTTER, S. J.; CHARAN, R. Building leaders at every level: a leadership pipeline. Ivey Business Journal, v. 65, n. 5, p. 21-35, 2001.

DUBAR, C. A sociologia do trabalho frente à qualificação e à competência. Educação e Sociedade, v. 19, n. 64, p. 87-103, 1998.

DUBRIN, A. J. Political behavior in organizations. Thousand Oaks, California: Sage, 2008.

DUTRA, J. S. Administração de carreiras: uma proposta para repensar a gestão de pessoas. São Paulo: Atlas, 1996.

DUTRA, J. S. Competências: conceitos e instrumentos para a gestão de pessoas na empresa moderna. Atlas, 2004.

DUTRA, J. S. Gestão de carreiras na empresa contemporânea. São Paulo: Atlas, 2010. 
DUTRA, J. S. Trajetórias de carreira nas organizações. Gestão de carreiras na empresa contemporânea. São Paulo: Atlas, 2010.

DUTRA, J. S. Carreira e gestão estratégica de pessoas. Gestão de carreiras na empresa contemporânea. São Paulo: Atlas, 2010.

DUTRA, J. S. Competências: conceitos e instrumentos para a gestão de pessoas na empresa moderna. Atlas, 2 ed, 2016.

DUTRA, J. S.; FLEURY, M. T. L.; RUAS, R. Competências: conceitos, métodos e experiências. São Paulo: Atlas, 2008.

EISENBERGER, R. et al. Perceived organizational support. Journal of Applied Psychology, v. 71, n. 3, p. 500-507, 1986.

EISENBERGER, R. et al. Reciprocation of perceived organizational support. Journal of Applied Psychology, v. 86, n. 1, p. 42, 2001.

EISENHARDT, K. M. Building theories from case study research. Academy of Management Review, v. 14, n. 4, p. 532-550, 1989.

EISENHARDT, K. M.; BOURGEOIS, L. J. Politics of strategic decision making in high-velocity environments: Toward a midrange theory. Academy of Management Journal, v. 31, n. 4, p. 737-770, 1988.

ELIAS, P. E. Reforma ou contrarreforma na proteção social à saúde. Lua Nova, v. 40, n. 41, p. 193-215, 1997.

ELLEN, B. P. Considering the positive possibilities of leader political behavior. Journal of Organizational Behavior, v. 35, n. 6, p. 892-896, 2014.

ELLEN, B. P.; FERRIS, G. R.; BUCKLEY, M. R.. Leader political support: Reconsidering leader political behavior. The Leadership Quarterly, v. 24, n. 6, p. 842$857,2013$.

ELLEN, B. P. Leader political support: Initial measure development and model test (unpublished doctoral dissertation). Tallahassee, Florida: Florida State University, 2015.

FARRELL, D.; PETERSEN, J. C. Patterns of political behavior in organization. Academy of Management Review, v. 7, n. 3, p. 403-412, 1982.

FEDOR, D. et al. The contribution of positive politics to the prediction of employee reactions. Journal of Applied Social Psychology, v. 38, n. 1, p. 76-96, 2008.

FEDOR, D. B.; MASLYN, J. M. Politics and political behavior: where else do we go from here? In: The many faces of multi-level issues. Emerald Group Publishing Limited, 2002. p. 271-285.

FERRIS, G. R. et al. Myths and politics in organizational contexts. Group \& Organization Management, v. 14, n. 1, p. 83-103, 1989. 
FERRIS, G. R.; JUDGE, T. A. Personnel/human resources management: A political influence perspective. Journal of Management, v. 17, n. 2, p. 447-488, 1991.

FERRIS, G. R.; KACMAR, K. M. Perceptions of organizational politics. Journal of Management, v. 18, n. 1, p. 93-116, 1992.

FERRIS, G. R. et al. Perceptions of organizational politics: Prediction, stress-related implications, and outcomes. Human Relations, v. 49, n. 2, p. 233-266, 1996.

FERRIS, G. R. et al. Development and initial validation of the political skill inventory. In: Academy of Management, 59th annual national meeting, Chicago. 1999. p. 1288-1356.

FERRIS, G. R. et al. Political skill at work. Organizational Dynamics, v. 28, n. 4, p. 25-37, 2000.

FERRIS, G. R.; HARRELL-COOK, G.; DULEBOHN, J. H. Organizational politics: The nature of the relationship between politics perceptions and political behavior. In: BACHARACH, S. B. Research in the Sociology of Organizations. Wagon Lane, Bingley, UK: Emerald Group Publishing Limited, 2000. p. 89-130.

FERRIS, G. R.; WITT, L. A.; HOCHWARTER, W. A. Interaction of social skill and general mental ability on job performance and salary. Journal of Applied Psychology, v. 86, n. 6 , p. $1075,2001$.

FERRIS, G. R. et al. Perceptions of organizational politics: Theory and research directions. Research in multi-level issues, v. 1, p. 179-254, 2002.

FERRIS, G. R. et al. Social influence processes in organizations and human resources systems. Research in personnel and human resources management. Emerald Group Publishing Limited, 2002. p. 65-127.

FERRIS, G. R. et al. Personal reputation in organizations. In: Organizational Behavior: A Management Challenge. Mahwah, NJ: Lawrence Erlbaum Associates, Publishers 2003. v. 201.

FERRIS, G. R. et al. Development and validation of the political skill inventory. Journal of Management, v. 31, n. 1, p. 126-152, 2005.

FERRIS, G. R.; DAVIDSON, S. L.; PERREWE, P. L. Political skill at work: Impact on work effectiveness. Mountain View, CA: Davies-Black Publishing, 2005.

FERRIS, G. R. et al. Political skill in organizations. Journal of Management, v. 33, n. 3, p. 290-320, 2007.

FERRIS, G. R. et al. Political skill construct and criterion-related validation: A twostudy investigation. Journal of Managerial Psychology, v. 23, n. 7, p. 744-771, 2008. 
FERRIS G. R.; HOCHWATER, W. A. Organizational Politics. In: ZEDECK, S. (Ed.) APA handbook of industrial and organizational psychology. Washington, DC: APA, 2011. p. 435-459.

FERRIS, G. R. et al. Political skill in the organizational sciences. In: Ferris, G. R Treadway, D. C. (Eds.). Politics in organizations: Theory and research considerations. New York: Routledge, Taylor and Francis Group, 2012, p. 487-529.

FERRIS, G. R.; TREADWAY, D. C. Politics in organizations: history, construct specification, and research directions. In: In: Ferris, G. R Treadway, D. C. (Eds.). Politics in organizations: Theory and research considerations. New York: Routledge, Taylor and Francis Group, 2012. p. 3-26.

FERRIS, G. R. et al. The role of reputation in the organizational sciences: A multilevel review, construct assessment, and research directions. In: Research in personnel and human resources management. Emerald Group Publishing Limited, 2014. p. 241-303.

FERRIS, G. R. et al. Social influence and politics in organizational research what we know and what we need to know. Journal of Leadership \& Organizational Studies, p. 154, 2016.

FISCHER, A. L.; ALBUQUERQUE, L.G de. Tendências de mudanças na gestão de pessoas das empresas brasileiras. Relatório de pesquisa. DELPHI RH-2010. São Paulo: MBA, USP, 2001.

FLYVBJERG, B. Five misunderstandings about case-study research. Qualitative Inquiry, v. 12, n. 2, p. 219-245, 2006.

FOA, U. G.; FOA, E. B. Societal structures of the mind. Springheld, IL: Thomas, 1974 ,

FONSECA, A. M. de O.; PORTO, J. B.; ANDRADE, J. E. B. Liderança: um retrato da produção científica brasileira/Leadership: A Portrait of Brazilian Scientific Production. Revista de Administração Contemporânea, v. 19, n. 3, p. 290, 2015.

FORNELL, C.; LARCKER, D. F. Evaluating Structural Equation Models with Unobservable Variables and Measurement Error. Journal of Marketing Research, v. 18, n. 1, p. 39-50, 1981.

FOUCAULT, M. A arqueologia do saber. Rio de Janeiro: Forense Universitária, 2005.

FOUCAULT, M. Vigiar e punir. Petrópolis-RJ: Vozes, 1987. v. 6.

FOUCAULT, Michel. Microfísica do poder: organização e tradução de Roberto Machado. Rio de Janeiro: Edições Graal, 1979. v. 4.

FREEMAN, R.; ROGERS, J. Workplace Representation and Participation Survey. Princeton: Princeton Survey Research Associates, 1994. 
FREEMAN, R.; ROGERS, J. Worker representation and participation survey: First report of findings. In: Proceedings of the forty-seventh annual meeting. Madison: Industrial Relations Research Association, 1995. p. 336-45.

FREITAS, A. B. de. Traços brasileiros para uma análise organizacional. Cultura organizacional e cultura brasileira. São Paulo: Atlas, 1997.

FRENCH, J. R. P.; RAVEN, B. The bases of social power. In: CATWRIGHT, D. (Ed.). Studies in social power. Ann Arbor, MI: Institute for Social Research, 1959.

FRIEDBERG, E. O poder e a regra. Dinâmicas da Ação Organizada. Lisboa: Instituto Piaget, p. 301, 1995.

FRIEDER, R. E.; BASIK, K. J. Political Skill, Behavioral Integrity, and Work Outcomes Test of a Multistage Model. Journal of Leadership \& Organizational Studies, p. 154, 2016.

FROMAN, Lewis A. People and politics. An Anlysis of the American Political System. Michigan: Prentice-Hall, 1962.

FURTADO, O; BOCK, A. M. B.; TEIXEIRA, M. L. T. Psicologias: uma introdução ao estudo de psicologia. São Paulo: Saraiva, 1999.

GABBAY, S. M.; ZUCKERMAN, E. W. Social capital and opportunity in corporate R\&D: The contingent effect of contact density on mobility expectations. Social Science Research, v. 27, n. 2, p. 189-217, 1998.

GANDZ, J.; MURRAY, V. V. The experience of workplace politics. Academy of Management Journal, v. 23, n. 2, p. 237-251, 1980.

GAULEJAC, V. de. Gestão como doença social: ideologia, poder gerencialista e fragmentação social. São Paulo: Ideias e Letras, p. 7-142, 2007.

GOLDBERG, L. R. Language and individual differences: The search for universals in personality lexicons. Review of Personality and Social Psychology, v. 2, n. 1, p. 141$165,1981$.

GOLEMAN, D. P. Emotional intelligence: Why it can matter more than IQ for character, health and lifelong achievement. New York: Bantam Books, 1995.

GOLEMAN, Daniel. Trabalhando com a inteligência emocional. Rio de Janeiro: Objetiva, 1998.

GOULDNER, A. W. The norm of reciprocity: A preliminary statement. American Sociological Review, v. 25, p. 161-178, 1960.

GRANOVETTER, M.; SOONG, R. Threshold models of diffusion and collective behavior. Journal of Mathematical sociology, v. 9, n. 3, p. 165-179, 1983. 
GRANOVETTER, M. Economic action and social structure: The problem of embeddedness. American Journal of Sociology, v. 91, n. 3, p. 481-510, 1985.

GUBA, E. G. et al. Competing paradigms in qualitative research. Handbook of Qualitative Research, v. 2, n. 163-194, p. 105, 1994.

HAIR JR., J. F. et al. Fundamentos de métodos de pesquisa em administração, Tradução de Lene Belon Ribeiro. Porto Alegre: Bookman, 2005.

HALL, R. H. Organizações: estruturas, processos e resultados. São Paulo: Pearson, 2004.

HALL, A. T. et al. Leader reputation and accountability in organizations: Implications for dysfunctional leader behavior. The Leadership Quarterly, v. 15, n. 4, p. 515-536, 2004.

HAMEL, G.; BREEN, B. O Futuro da Gestão. Lisboa: Actual Editora, 2007.

HARRIS, K. J. et al. The impact of political skill on impression management effectiveness. Journal of Applied Psychology, v. 92, n. 1, p. 278, 2007.

HAUSKNECHT, J. P.; RODDA, J.; HOWARD, M. J. Targeted employee retention: Performance based and jobrelated differences in reported reasons for staying. Human Resource Management, v. 48, n. 2, p. 269-288, 2009.

HICKSON, D. J. et al. A strategic contingencies' theory of intraorganizational power. Administrative Science Quarterly, v. 16, p. 216-229, 1971.

HOCHWARTER, W. The positive side of organizational politics. In: FERRIS, G. R.; TREADWAY, D. C. Politics in organizations: Theory and research considerations, New York: Routledge/Taylor \& Francis, 2012. p. 27-65.

HOFFMAN, M. L. Moral internalization: Current theory and research. Advances in Experimental Social Psychology, v. 10, p. 85-133, 1977.

HOGAN, J.; HOLLAND, B. Using theory to evaluate personality and job-performance relations: a socioanalytic perspective. Journal of Applied Psychology, v. 88, n. 1, p. 100-112, Feb 2003.

HOGAN, R.; BLICKLE, G. Socioanalytic theory. Christianesen N. D. Tett R. P. (Eds.), Handbook of personality at work. New York: Routledge, 2013. p. 53-70.

HOGAN, R.; KAISER, R. B. What we know about leadership. Review of General Psychology, v. 9, n. 2, p. 169, 2005.

HOGAN, R.; SHELTON, D. A socioanalytic perspective on job performance. Human Performance, v. 11, n. 2-3, p. 129-144, 1998.

HOLLANDER, E. P.; JULIAN, J. W. Studies in leader legitimacy, influence, and innovation. Group Processes. In: BERKOWITZ, L. (Ed.). Advances in Experimental Social Psychology. New York: Academic Press, 1978. v. 2. 
HOLLANDER, E. P. Legitimacy, power, and influence: A perspective on relational features of leadership. In: CHEMERS, M.; AYMAN, R. Theory and research: perspectives and directions. New York: Academic Press, 1993. p. 29-47.

HOOIJBERG, R. A multidirectional approach toward leadership: An extension of the concept of behavioral complexity. Human Relations, v. 49, n. 7, p. 917-946, 1996.

HOOIJBERG, R.; HUNT, J. G. J.; DODGE, G. E. Leadership complexity and development of the leaderplex model. Journal of Management, v. 23, n. 3, p. 375-408, 1997.

HOULT, T. F. Dicionário de Sociologia Moderna. Totowa: Littlefield, 1969.

HOUSE, R. J.; ADITYA, R. N. The social scientific study of leadership: Quo vadis? Journal of Management, v. 23, n. 3, p. 409-473, 1997.

HOUSE, R. J. Leadership in the twenty-first century: A speculative inquiry. Reginald H. Jones Center, Wharton School, University of Pennsylvania, 1995.

HREBINIAK, L. G.; JOYCE, W. F. Implementing strategy. New York, NY: Macmillan, 1984.

HUSELID, M. A. The impact of human resource management practices on turnover, productivity, and corporate financial performance. Academy of Management Journal, v. 38, n. 3, p. 635-672, 1995.

JAQUES, E. In praise of hierarchy. In: Grahame Thompson \& ea (Eds.). Markets, Hierarchies \& Networks: the Coordination of Social Life, 1991. p. 108-119.

JOHNSON, C.; DOWD, T. J.; RIDGEWAY, C. L. Legitimacy as a social process. Annual Review of Sociology, v. 32, p. 53-78, 2006.

JONES, E. E. Interpersonal perception. New York: WH Freeman/Times Books/Henry Holt \& Co, 1990.

JUDGE, T. A.; BRETZ JR., R. D. Political influence behavior and career success. Journal of Management, v. 20, n. 1, p. 43-65, 1994.

KAHNEMAN, D. Pensar depressa e devagar. Lisboa: Círculo de Leitores, 2012.

KANTER, R. M. Power failure in management circuits. Harvard Business Review, v. 57, n. 4, p. 65, 1979.

KATZ, D.; KAHN, R. L. Organizations and the system concept. In: Shafritz J. M.; Whitbeck, P. H. (Eds.). Classics of organization theory, Oak Park, Ill: Moore, Klein, E., \& Izzo, J. B., 1978. p. 161-172.

KRACKHARDT, D. Assessing the political landscape: Structure, cognition, and power in organizations. Administrative Science Quarterly, p. 342-369, 1990. 
KEAN, S. et al. Followers and the co-construction of leadership. Journal of Nursing Management, v. 19, n. 4, p. 507-516, 2011.

KIMURA, T. A review of political skill: Current research trend and directions for future research. International Journal of Management Reviews, v. 17, n. 3, p. 312-332, 2015.

KIPNIS, D.; SCHMIDT, S. M.; WILKINSON, I. Intraorganizational influence tactics: Explorations in getting one's way. Journal of Applied Psychology, v. 65, n. 4, p. 440, 1980.

KIPNIS, D.; SCHMIDT, S. M. Upward-influence styles: Relationship with performance evaluations, salary, and stress. Administrative Science Quarterly, v. 33, p. 528-542, 1988.

KIRCHHEIMER, O. Politics, Law, and Social Change: Selected Essays. New York: Columbia University Press, 1969.

KLEINER, K. Rethinking leadership and followership: A student's perspective. In: RIGGIO, R. E.; CHALEFF, I.; LIPMAN-BLUMEN, J. (Eds.). The art of followership. San Francisco, CA: Jossey- Bass, 2008. p. 89-93.

KOLODINSKY, R. W.; HOCHWARTER, W. A.; FERRIS, G. R. Nonlinearity in the relationship between political skill and work outcomes: Convergent evidence from three studies. Journal of Vocational Behavior, v. 65, n. 2, p. 294-308, 2004.

KOLODINSKY, R. W.; TREADWAY, D. C.; FERRIS, G. R. Political skill and influence effectiveness: Testing portions of an expanded Ferris and Judge (1991) model. Human Relations, v. 60, n. 12, p. 1747-1777, 2007.

KOTTER, J. P. Power and influence. Beyond formal authority. New York, NY: Free Press, 1985

KOUZES, J. M.; POSNER, B. Z. O desafio da liderança: como conseguir feitos extraordinários em organizações. Rio de Janeiro (RJ): Campus, 1991.

LASSWELL, H. D.; KAPLAN, A. Power and society: A framework for political inquiry, New Haven: Yale University Press, 1936.

LAZEAR, E. P.; ROSEN, S. Rank-Order Tournaments as Optimum Labor Contracts. The Journal of Political Economy, v. 89, n. 5, p. 841-864, 1979.

LEACH, C. W.; ELLEMERS, N.; BARRETO, M. Group virtue: the importance of morality (vs. competence and sociability) in the positive evaluation of ingroups. Journal of Personality and Social Psychology, v. 93, n. 2, p. 234, 2007.

LEARY, M. R.; KOWALSKI, R. M. Impression management: A literature review and two-component model. Psychological Bulletin, v. 107, n. 1, p. 34, 1990. 
LE BOTERF, G. Desenvolvendo a competência dos profissionais. Porto Alegre: Artmed, 2003.

LE BOTERF, G. Construire les compétences individuelles et collectives. Paris: Les Éditions d'Organisations, 2001.

LE BOTERF, G. L'ingénierie des compétences. Paris: Les Editions d'Organisations, 1999.

LE BOTERF, G. De la compétence - essai sur un attracteur étrange. Quatrième Tirage. Paris: Les Éditions d'Organisations, 1995.

LEPAK, D. P.; SNELL, S. A. The human resource architecture: Toward a theory of human capital allocation and development. Academy of Management Review, v. 24, n. 1, p. 31-48, 1999.

LEPISTO, D. A., PRATT, M. G. Politics in perspectives: on the theoratical challenges and opportunities in studying organizational politics. Politics in organizations: Theory and research considerations, 2012. p. 27-65.

LEWIS, R. E.; HECKMAN, R. J. Talent management: A critical review. Human Resource Management Review, v. 16, n. 2, p. 139-154, 2006.

LIPSET, S. M. Political Man. New York: Doubleday, 1960.

LIU, Y. et al. Dispositional antecedents and outcomes of political skill in organizations: A four-study investigation with convergence. Journal of Vocational Behavior, v. 71, n. 1, p. 146-165, 2007.

LIU, Y.; LIU, J.; WU, L. Are you willing and able? Roles of motivation, power, and politics in career growth. Journal of Management, v. 36, n. 6, p. 1432-1460, 2010.

LONDON, M.; STUMPF, S. A. Managing careers. Reading MA: Addison Wesley Publishing Company, 1982.

LORD, R. G.; EMRICH, C. G. Thinking outside the box by looking inside the box: Extending the cognitive revolution in leadership research. The Leadership Quarterly, v. 11, n. 4, p. 551-579, 2001.

LUKES, S. Poder e autoridade. História da análise sociológica. Rio de Janeiro: Zahar, 1980.

LUTHANS, F.; HODGETTS, R. M.; ROSENKRANTZ, S. A. Real managers. Cambridge, MA: Ballinger, 1988.

LUTHANS, F.; ROSENKRANTZ, S. A.; HENNESSEY, H. W. What do successful managers really do? An observation study of managerial activities. The Journal of Applied Behavioral Science, v. 21, n. 3, p. 255-270, 1985. 
LYNCH, P. D.; EISENBERGER, R.; ARMELI, S. Perceived organizational support: Inferior versus superior performance by wary employees. Journal of Applied Psychology, v. 84, n. 4, p. 467, 1999.

MALCOMSON, J. M. Work incentives, hierarchy, and internal labor markets. The Journal of Political Economy, v. 92, n. 3, p. 486-507, 1984.

MALVEZZI, S. Fazenda Córrego Azul - a construção da liderança. Manuscrito. Brasilândia, 2015.

MANGHAM, I. L. The politics of organizational change. Greenwood Pub Group, 1979.

MANSUR, J. A.; SOBRAL, F. J. B. Política na terra do" jeitinho": consequências dos comportamentos políticos em organizações no brasil. Revista de Administração Mackenzie, v. 12, n. 6, p. 165, 2011.

MANSUR, J A; SOBRAL, F. J. B. Política na terra do "jeitinho": implicações dos comportamentos políticos em organizações no Brasil. In: 34 ENANPAD, 34, 2010. Anais... Rio de Janeiro: ANPAD, 2010.

MARCH, J. G.; EASTON, D. The power of power. In: Shafritz, J. S.; Ott, J. S.; Jang, Y. S. (Eds.). Classics of Organization Theory. Cengage Learning.1966.

MURRAY, Edelman. The symbolic uses of politics. Urbana: University of Illinois Press, 1964.

MARSHALL, C.; ROSSMAN, G. B. Designing qualitative research. Thousand Oaks, USA: Sage, 1999.

MARSHALL, G. A dictionary of sociology. New York: Oxford University Press, 1994.

MARTINS, G. de A.; THEÓPHILO, C. R. Metodologia da investigação científica para ciências sociais aplicadas. São Paulo: Atlas, 2007. v. 225.

MATUS, C. Chimpanzé, Maquiavel e Ghandi: estratégias políticas. São Paulo: FUNDAP, 1996.

MAXWELL, J. A. Qualitative research design: An interactive approach. Thousand Oaks, USA: Sage, 1996.

MAYER, J. D. A tale of two visions: Can a new view of personality help integrate psychology? American Psychologist, v. 60, n. 4, p. 294, 2005.

MCCLELLAND, D. C. The two faces of power. Journal of international Affairs, v. 24, p. 29-47, 1970.

MCFARLAND, L. A.; VAN IDDEKINGE, C. H.; PLOYHART, R. E. Measurement and methodology in organizational politics research. In: FERRIS, G. R.; TREADWAY, 
D. C. Politics in organizations: Theory and research considerations. New York: Routledge, 2012. p. 99-129.

MCINTYRE, M. G. Secrets to winning at office politics: How to achieve your goals and increase your influence at work. New York: Macmillan, 2005.

MEEKER, B. F. Decisions and exchange. American Sociological Review, v. 36, n. 3, p. 485-495, Jun. 1971.

MERTON, R. K. Teoria social e estrutura. São Paulo: Mestre Jou, 1970.

MILES, R. Class, race and ethnicity: A critique of Cox's theory. Ethnic and Racial Studies, v. 3, n. 2, p. 169-187, 1980.

MILGRAM, S. Behavioral Study of obedience. The Journal of Abnormal and Social Psychology, v. 67, n. 4, p. 371, 1963.

MINAYO, M. C. de S. O desafio do conhecimento: pesquisa qualitativa em saúde. 7 ed. São Paulo: Hucitec; Rio de Janeiro: Abrasco, 2000.

MINTZBERG, H. The Manageris Job: Folklore and Fact. Harvard Business Review. v. 53, n. 4, p. 49-61, Jul./Aug. 1975.

MINTZBERG, $\mathrm{H}$. The organization as political arena. Journal of Management Studies, v. 22, n. 2, p. 133-154, 1985.

MINTZBERG, H. Power in and around organizations. Englewood Cliffs, NJ: PrenticeHall, 1983.

MIRANDA, S. O tabu do poder e da política nos estudos organizacionais. Revista de Administração da UFSM, v. 2, n. 1, p. 10-20, 2009.

MORGAN, G.; BERGAMINI, C. W.; CODA, R. Imagens da organização. São Paulo: Atlas, 1996.

MORIN, E. Introdução ao pensamento complexo. Lisboa: Instituto Piaget, 1995.

MORIN, E. Educação e complexidade: os sete saberes e outros ensaios. São Paulo: Cortez, 2002.

MOTTA, F. C., CALDAS, M. P. Cultura organizacional e cultura brasileira. 8 reimpr.São Paulo: Atlas, 2009.

MOTTA, Fernando C. Prestes; ALCADIPANI, Rafael. O pensamento de Michel Foucault na teoria das organizações. Revista de Administração, v. 39, n. 2, p. 117-128, 2004.

MUNYON, T. P. et al. Political skill and work outcomes: A theoretical extension, metaanalytic investigation, and agenda for the future. Personnel Psychology, v. 68, n. 1, p. 143-184, 2015. 
MURRAY, Victor; GANDZ, Jeffrey. Games executives play: Politics at work. Business Horizons, v. 23, n. 6, p. 11-23, 1980.

NAHAPIET, J.; GHOSHAL, S. Social capital, intellectual capital, and the organizational advantage. Academy of management review, v. 23, n. 2, p. 242-266, 1998.

NALEBUFF, B. J.; STIGLITZ, J. E. Prizes and incentives: towards a general theory of compensation and competition. The Bell Journal of Economics, v. 14, 21-43, 1983.

NOGUEIRA, C. A análise do discurso. In: ALMEIDA, L.; FERNANDES, E. (Eds.). Métodos e técnicas de avaliação: novos contributos para a prática e investigação. Braga: CEEP, 2001.

NORTHOUSE, P. G. Leadership: Theory and practice. Thousand Oaks, CA: Sage, 2012.

OSBORN, R.; MORRIS, F.; CONNOR, F. Emerging technologies: The challenge to leadership theory. Leaders and Managers, p. 360-365, 1984.

PAGÈS, M. O poder das organizações. São Paulo: Atlas, 1987.

PELED, A. Politicking for success: The missing skill. Leadership \& Organization Development Journal, v. 21, n. 1, p. 20-29, 2000.

PENTEADO, J. R. W. Técnica de chefia e liderança. São Paulo: Pioneira, 1978.

PENTEADO, J. R. W. Técnica de chefia e liderança. São Paulo: Pioneira, 1986.

PERREWÉ, P. L. et al. Neutralizing job stressors: Political skill as an antidote to the dysfunctional consequences of role conflict. Academy of Management Journal, v. 47, n. 1, p. 141-152, 2004.

PFEFFER, J. A political perspective on careers: interests, networks, and environments In: ARTHUR, M. B. et al. (Ed.). Handbook of career theory. Cambridge: Cambridge University Press, 1989.

PFEFFER, J.; COHEN, Y. Determinants of Internal Labor Markets in Organizations. Administrative Science Quarterly, v. 29, n. 4, 1984.

PFEFFER, J.; SALANCIK, G. R. The external control of organisations. New York: Harper\&Row, 1978.

PFEFFER, J. Power in organizations. Marshfield, MA: Pitman, 1981.

PFEFFER, J. Managing with power: Politics and influence in organizations. Boston: Harvard Business Press, 1992. 
PFEFFER, J. Power: Why some people have it - and others don't. New York: HarperCollins. 2010a.

PFEFFER, J. Power play. Boston: Harvard Business Review, v. 88, n. 7/8, p. 84-92, $2010 b$.

PLATÃO. A República. São Paulo: Martin Claret, 2000.

PORTER, L. W.; ALLEN, R. W.; ANGLE, H. L. The politics of upward influence in organizations. Organizational Influence Processes, v. 2, p. 431-445, 2003.

PORTER, L. W.; ALLEN, R. W.; ANGLE, H. L. The politics of upward influence in organizations. In: CUMMINGS, L. L.; STAW, B. M. (Eds.). Research in organizational behavior. Greenwich, CT: JAI, 1981. v. 3.

PRATES, M. A. S.; BARROS, B. T. O estilo brasileiro de administrar. In: PRESTES MOTTA, F. C.; CALDAS, M. P. Cultura organizacional e cultura brasileira. São Paulo: Atlas, 1997. p. 55-69.

QUEIROZ, C.; LEITE, C.. O elo da gestão de carreira: o papel do empregado, da liderança e da organização. São Paulo: DVS Editora, 2010.

RAES, A. M. et al. The interface of the top management team and middle managers: A process model. Academy of Management Review, v. 36, n. 1, p. 102-126, 2011.

RAMOS, A. G. A Nova ciencia das organizações: uma reconceituação da riqueza das nações. Rio de Janeiro: Fundação Getúlio Vargas, 1981.

RANK, O. N. Formal structures and informal networks: Structural analysis in organizations. Scandinavian Journal of Management, v. 24, n. 2, p. 145-161, 2008.

RASINSKI, K.; TYLER, T. R.; FRIDKIN, K. Exploring the function of legitimacy: Mediating effects of personal and institutional legitimacy on leadership endorsement and system support. Journal of Personality and Social Psychology, v. 49, n. 2, p. 386, 1985.

RHINESMITH, S. H. Guia gerencial para a globalização. Rio de Janeiro: Berkeley, 1993.

RHOADES, L.; EISENBERGER, R. Perceived Organizational Support: A Review of the Literature. Journal of Applied Psychology, v. 87, n. 4, p. 698-714, 2002.

RIDGEWAY, C. L.; BERGER, J. Expectations, legitimation, and dominance behavior in task groups. American Sociological Review, v. 51, p. 603-617, 1986.

RUGMAN, A. The end of globalization. London: Random House, 2000.

SADLER, P. Leadership and organizational learning. In: Dierkes, M.; Antal, A. B.; Child, J.; Nonaka, I. (Eds.). Handbook of organizational learning and knowledge, Oxford, UK: Oxford University Press, 2001. p. 415-27. 
SALANCIK, G. R.; PFEFFER, J. The bases and use of power in organizational decision making: The case of a university. Administrative Science Quarterly, v. 19, n. 4, p. 453-473, Dec. 1974.

SALANCIK, G. R.; PFEFFER, J. Who gets power-and how they hold on to it: A strategic-contingency model of power. Organizational dynamics, v. 5, n. 3, p. 3-21, 1978.

SANT'ANNA, A. S. Competências de liderança ou gerenciais? Uma análise sob a perspectiva foucaultiana de poder. In: NELSON, R. E.; A. S. SANT'ANNA, A. S. (Orgs.). Liderança: entre a tradição, a modernidade e a pós-modernidade. Rio de Janeiro: Elsevier, 2010.

SCHRIESHEIM, C. A. et al. The folly of theorizing "A" but testing "B": A selective level-of-analysis review of the field and a detailed leader-member exchange illustration. The Leadership Quarterly, v. 12, n. 4, p. 515-551, 2001.

SEDERBERG, P. C. The Politics of Meaning Power and Explanation in the Construction of Social Reality. Tucson: University of Arizona Press, 1984.

SEIBERT, S. E.; KRAIMER, M. L.; LIDEN, R. C. A social capital theory of career success. Academy of Management Journal, v. 44, n. 2, p. 219-237, 2001.

SELIGMAN, M. E. P. Positive psychology, positive prevention, and positive therapy. Handbook of Positive Psychology, v. 2, p. 3-12, 2002.

SELZNICK, P. Leadership in Administration: A sociological interpretation. In: FOSS, N. (Org.). Resources Firms and Strategies. Oxford: Oxford University Press, p. 21-26, 1997.

SELZNICK, P. TVA and the grass roots: A study in the sociology of formal organization. New York: Harper \& Row, 1966.

SEMANDAR, A.; ROBBINS, G.; FERRIS, G. Comparing the effects of multiple social effectiveness constructs in the prediction of managerical performance. Journal of Organizational Behavior, v. 27, p. 443-461, 2006.

SENGE, P. M.; KAUFER, K. H. Comunidades de líderes ou ausência de liderança. In: CHOWDHURY, S. Administração no século XXI: o modo de gerenciar hoje e no futuro. Tradução de Maria Lúcia G. L. Rosa. São Paulo: Pearson Education do Brasil, 2003. p. 185-204.

SHAMIR, B. From passive recipients to active coproducers: followers' roles in the leadership process. In: SHAMIR, B.; PILLAI, R. P.; BLIGH, M. C.; UHL-BIEN, M. (Eds.) Follower-centered perspectives on leadership: A tribute to the memory of James R. Meindl. Greenwich, CT: Information Age Publishing, 2007.

SHELL, G. R.; MOUSSA, M. The art of woo: Using strategic persuasion to sell your ideas. New York: Penguin, 2007. 
SHERIDAN, J. E. et al. Effects of corporate sponsorship and departmental power on career tournaments. Academy of Management Journal, v. 33, n. 3, p. 578-602, 1990.

SHORE, L. M.; SHORE, T. H. Perceived organizational support and organizational justice. In: CROPANZANO, R. S.; KACMAR, K. M. Organizational politics, justice, and support: Managing the social climate of the workplace. Westport, CT: Quorum, 1995. p. 149-164.

SIMON, A. F. The winning message: Candidate behavior, campaign discourse, and democracy. Cambridge: Cambridge University Press, 2002.

SMITH, A. D. et al. A qualitative study of high-reputation plant managers: Political skill and successful outcomes. Journal of Operations Management, v. 27, n. 6, p. 428-443, 2009.

SNYDER, M. Basic research and practical problems: The promise of a" functional" personality and social psychology. Personality and Social Psychology Bulletin, v. 19, n. 3, p. 251-264, 1993.

SOLL, Jack B.; MILKMAN, Katherine L.; PAYNE, John W. Outsmart your own biases. Harvard Business Review, v. 93, n. 5, p. 64-71, 2015.

SPENCE, A. M. Market signaling: Informational transfer in hiring and related screening processes. Boston: Harvard University Press, 1974.

SRHM - Society for Human Resource Management: the top workplace trends according to HR professionals. SHRM Workplace Forecast. Alexandria - VA, USA, v. 1, n. 1, p. $1-70,2013$.

STAHL, G. K. et al. Global talent management: How leading multinationals build and sustain their talent pipeline, Faculty \& research working paper. Fontainebleau, France: INSEAD, 2007.

STAMP, G. The individual, the organisation and the path to mutual appreciation. Personnel Management, v. 21, n. 7, p. 28-32, 1989.

STAMP, G. The essence of levels of work. Training Materials. Southern Africa: Bioss, 1993a.

STAMP, G. Making the mosto f Human capital from competitive advantage. Documento interno da Bioss - Brunnel Institute of Organization and Social Studies, June, 1994a.

STAMP, G. Key relationship appreciation. Documento interno da Bioss - Brunnel Institute of Organization and Social Studies, Aug. 1994b.

STAMP, G.; STAMP, C. Wellbeing at work: aligning purposes, people, strategies and structures. International Journal of Career Management, v. 5, n. 3, 1993 b. 
STEWART, G. L.; CARSON, K. P. Moving beyond the mechanistic model: An alternative approach to staffing for contemporary organizations. Human Resource Management Review, v. 7, n. 2, p. 157-184, 1997.

STURGES, J. What it means to succeed: Personal conceptions of career success held by male and female managers at different ages. British Journal of Management, v. 10, n. 3, p. 239-252, 1999.

SUSSMAN, L. et al. Organizational Politics: Tactics, Channels, andHierarchical Roles. Journal of Business Ethics, v. 40, n. 4, p. 313-329, 2002.

TANURE, B.; EVANS, P.; PUCK, V. Virtudes e pecados capitais: a gestão das pessoas no Brasil. 2. ed. Rio de Janeiro: Elsevier, 2007.

TEDESCHI, J. T.; MELBURG, V. Impression management and influence in the organization. Research in the Sociology of Organizations, v. 3, n. 31-58, 1984.

THUNNISSEN, M.; BOSELIE, P.; FRUYTIER, B. A review of talent management:'infancy or adolescence?'. The International Journal of Human Resource Management, v. 24, n. 9, p. 1744-1761, 2013.

TOFFLER, A. Os novos poderes. Lisboa, Portugal: Livros do Brasil, 1991.

TOST, L. P. An integrative model of legitimacy judgments. Academy of Management Review, v. 36, n. 4, p. 686-710, 2011.

TREADWAY, D. C. et al. Leader political skill and employee reactions. The Leadership Quarterly, v. 15, n. 4, p. 493-513, 2004.

TREADWAY, D. C. et al. Social influence and interpersonal power in organizations: Roles of performance and political skill in two studies. Journal of Management, v. 39, n. 6, p. 1529-1553, 2013.

TREADWAY, D. C. Political will in organizations. Politics in organizations: Theory and research considerations, p. 531-556, 2012.

TREADWAY, D. C. et al. Political will, political skill, and political behavior. Journal of Organizational Behavior, v. 26, n. 3, p. 229-245, 2005.

TUSHMAN, M. L. A political approach to organizations: A review and rationale. Academy of Management Review, v. 2, n. 2, p. 206-216, 1977.

TVERSKY, A.; KAHNEMAN, D. The framing of decisions and the psychology of choice. In: Environmental Impact Assessment, Technology Assessment, and Risk Analysis. Springer Berlin Heidelberg, 1985. p. 107-129.

TYLER, T. R. Why people obey the law: Procedural justice, legitimacy, and compliance. New Haven: Yale University Press, 1990. 
TYLER, T. R.; LIND, E. A. A relational model of authority in groups. Advances in Experimental Social Psychology, v. 25, p. 115-191, 1992.

TYLER, T. R. The psychology of legitimacy: A relational perspective on voluntary deference to authorities. Personality and Social Psychology Review, v. 1, n. 4, p. 323345, 1997.

ULLAH, S. et al. A synthesis of literature on organizational politics. Far East Journal of Psychology and Business, v. 3, n. 3, p. 36-49, 2011.

ULLAH, S. et al. The dark side of employee behavior: An explanation of factors instigating organizational politics. African Journal of Business Management, v. 5, n. 26, p. 10428, 2011.

VAN SETERS, D. A.; FIELD, R. H. The evolution of leadership theory. Journal of Organizational Change Management, v. 3, n. 3, p. 29-45, 1990.

VAN VELSOR, E.; LESLIE, J. B. Why executives derail: Perspectives across time and cultures. The Academy of Management Executive, v. 9, n. 4, p. 62-72, 1995.

VIEIRA, A.; PEREIRA, G. B.; ROSCOE, M. T. A. Liderança, legitimidade e mérito. In: NELSON, R. E.; SANT'ANNA, A. S. (Orgs.) Liderança entre a tradição, a modernidade ea pós-modernidade. Rio de Janeiro: Elsevier, 2010.

VIGODA-GADOT, E.; DRORY, A. (Ed.). Handbook of organizational politics. Cheltenham: Edward Elgar Publishing, 2006.

VREDENBURGH, D. J.; MAURER, J. G. A process framework of organizational politics. Human Relations, v. 37, n. 1, p. 47-65, 1984.

WAYNE, S. J.; FERRIS, G. R. Influence tactics, affect, and exchange quality in supervisor-subordinate interactions: A laboratory experiment and field study. Journal of Applied Psychology, v. 75, n. 5, p. 487, 1990.

WEBER, M. The theory of economic and social organization. Translated by A. M, Henderson and Talcott Parsons. New York: Oxford University Press, 1947.

WEBER, M. Economy and Society. Edited by Guenther Roth and Claus Wittich. Berkeley and Los Angeles: University of California Press, 1978. 2 v.

WEI, L. Q.; CHIANG, F. F. T.; WU, L. Z. Developing and utilizing network resources: Roles of political skill. Journal of Management Studies, v. 49, n. 2, p. 381-402, 2012.

WOOLDRIDGE, B.; SCHMID, T.; FLOYD, S. W. The middle management perspective on strategy process: contributions, synthesis, and future research. Journal of Management, v. 34, n. 6, 1190-1221, 2008.

WRIGHT, P. M.; DUNFORD, B. B.; SNELL, S. A. Human resources and the resource based view of the firm. Journal of Management, v. 27, n. 6, p. 701-721, 2001. 
WRONG, D. H. Power: Its forms, bases, and uses. New Brunswick, New Jersey: Transaction Publishers, 1980.

YAMMARINO, F. J.; DANSEREAU, F.; KENNEDY, C. J. A multiple-level multidimensional approach to leadership: Viewing leadership through an elephant's eye. Organizational Dynamics, v. 29, n. 3, p. 143-163, 2001.

YAMMARINO, F. J.; MUMFORD, M. D. Leadership and organizational politics: A multilevel review and framework for pragmatic deals. In: Ferris G. R., Treadway D. C. (Eds.). Politics in organizations: Theory and research considerations, New York, NY: Routledge, 2012. p. 323-354.

YAMMARINO, F. Leadership past, present, and future. Journal of Leadership \& Organizational Studies, v. 20, n. 2, p. 149-155, 2013.

YIN, R. K. Case study research: Design and methods. Thousand Oaks, CA: Sage publications, 2009.

YUKL, G. A. Leadership in organizations. Delhi, India: Pearson Education India, 1989.

YUKL, G. An evaluation of conceptual weaknesses in transformational and charismatic leadership theories. The Leadership Quarterly, v. 10, n. 2, p. 285-305, 1999.

YUKL, G. Effective Leadership Behaviors: What We Know and What Questions Need More Attention? The Academy of Management Perspectives, v. 26, n. 4, p. 66-85, 2012.

ZACCARO, S. J. et al. Leadership and social intelligence: Linking social perspectiveness and behavioral flexibility to leader effectiveness. The Leadership Quarterly, v. 2, n. 4, p. 317-342, 1991.

ZACCARO, S. J. Organizational leadership and social intelligence. In: Kravis-de Roulet Leadership Conference, 9th, Apr, 1999, Claremont McKenna Coll, Claremont, CA, US. Lawrence Erlbaum Associates Publishers, 2002.

ZALD, M. N. Power in organizations. Tenesse: Vanderbilt Univ Press, 1970.

ZALEZNIK, A. Managers and leaders: Are they different? Harvard Business Review, v. 55, n. 3, p. 67-78, 1977.

ZANZI, A.; O'NEILL, R. M. Sanctioned versus non-sanctioned political tactics. Journal of Managerial Issues, p. 245-262, 2001.

ZARIFIAN, P. A gestão da e pela competência. Rio de Janeiro: Centro Internacional para Educação, Trabalho e Transferência de Tecnologia, 1996.

ZARIFIAN, P. Objetivo competência: por uma nova lógica. São Paulo: Atlas, 2001. 
ZELDITCH, M. Jr.; WALKER, H. A. Legitimacy and the stability of authority. Advances in Group Processes, v. 1, p. 1-25, 1984.

ZINKO, R. et al. Personal reputation in organizations: Two study constructive replication and extension of antecedents and consequences. Journal of Occupational and Organizational Psychology, v. 85, n. 1, p. 156-180, 2012.

ZWICKER, R.; SOUZA, C. A. de; BIDO, D. de S. Uma revisão do modelo do grau de informatização de empresas: novas propostas de estimação e modelagem usando PLS (partial least squares). In: ENCONTRO DA ASSOCIAÇÃONACIONAL DE PÓSGRADUAÇÃO E PESQUISA EM ADMINISTRAÇÃO, 32., 2008, Rio de Janeiro. Anais... Rio de Janeiro: Anpad, 2008. 


\section{ANEXOS}

\section{QUESTIONÁRIO DE PESQUISA PARA GESTORES}

\section{APRESENTAÇÃO}

Eu, Paula Sousa Brant e Melo, RG: 56.322.471-X, responsável principal pelo projeto de Tese: A contribuição da competência política na legitimação da liderança, o qual pertence ao curso de Doutorado em Administração e foco em Gestão de Pessoas da Universidade de São Paulo - FEA-USP. Os achados desse estudo servirão para apresentação da defesa da Tese e para possíveis publicações de artigos ou livro. Esse estudo esta sendo realizado com a orientação do Prof. Dr. Joel Souza Dutra.

Em conformidade com a ética acadêmica, serão mantidos confidenciais os nomes dos respondentes e de possíveis nomes citados durante a entrevista e também os dados coletados que possam ser julgados como confidenciais pelos respondentes. Temos o objetivo de explorar o processo político na carreira das lideranças. A carreira de liderança implica na atuação na "arena política" da organização. Diferentes gestores são mais ou menos efetivos no uso do comportamento político como consequência de suas habilidades. A questão política é inerente ao exercício da liderança. Essa pesquisa visa inserir esse tema na agenda das pesquisas nacionais. Balancear os aspectos negativos e positivos do comportamento político. Acreditamos que a conscientização sobre a perspectiva política e a competência política da liderança possa contribuir para as empresas no processo de contratação e desenvolvimento de suas lideranças. Da mesma maneira a participação dos profissionais nessa pesquisa pode ser interessante, na medida em que, o respondente poderá refletir sobre um tema importante e pouco explorado no país e fazer uma análise sobre suas próprias competências.

A pesquisa consiste em perguntas abertas sobre a temática (12) e preenchimento de questionário com perguntas fechadas de autor relato sobre competência política, reputação e legitimidade (33). A escolha pelos gestores se dá pelo fato de esses profissionais lidarem mais intensamente com as disputas por recursos, reconhecimento, negociação e representação na "arena política da organização".

A entrevista poderá levar em média de 30 minutos a 1 hora, dependendo do interesse e disponibilidade do próprio entrevistado. Em relação ao procedimento da entrevista, ela poderá ser gravada, somente nos casos em que o respondente estiver de acordo, uma vez que a gravação serve apenas para facilitar o processo de consolidação das informações por parte do pesquisador. Após a entrevista, os pesquisadores farão uma transcrição das respostas que será enviada aos respondentes por e-mail para que os mesmos possam checar as informações, podendo sugerir alterações que julguem necessárias para seu maior conforto e para que a transcrição seja a mais fidedigna possível. O entrevistado poderá ainda fazer comentários adicionais ou o acréscimo em alguma de suas respostas pelo e-mail ou telefone abaixo:

Atenciosamente.

Paula Brant e Melo

Pesquisador Principal

Universidade de São Paulo - FEA- USP 
(Espaço reservado para o Pesquisador)

Nome:

Dados demográficos

01. Gênero

Masculino ( ) Feminino ( ) Outro ( )

02.Idade (em anos)

03. Nível de Escolaridade (completo)

Curso superior incompleto ( )

Ensino Superior (curso universitário graduação) ( )

Especialização (lato sensu pelo menos 360 horas) ou MBA 4 ( )

Mestrado profissional ou acadêmico ( )

Doutorado ou pós-doutorado ( )

04. Qual o tipo de organização em que você trabalha? *

Organização pública ( )

Empresa privada ( )

Organização do Terceiro Setor ( )

Outro ( ):

04. Cargo atual:

05. Quanto tempo trabalha na empresa

07. Quantos funcionários aproximadamente tem a empresa?

08. Ramo de atividade da empresa

09. Em que cidade e Estado está situada

E-mail de contato:

Nesta entrevista será bem-vinda a fala espontânea do entrevistado, que tem

liberdade para usar seu conhecimento e experiência profissional e opinião pessoal para responder as perguntas; o entrevistado poderá citar exemplos que facilitem ou ilustrem sua resposta, assim como fazer comentários gerais ou específicos sobre o assunto da questão e seu contexto. 
Dados sobre a entrevista: (Espaço reservado para o Pesquisador)

- Data:

- Horário de início da entrevista:

- Local (incluindo a cidade):

- Tipo da entrevista (face-a-face, mediada, on-line):

- Forma de registro dos dados (anotação, gravação - áudio, ou e-mail);

\section{Roteiro de entrevista}

1 Ao assumir cargos mais altos na organização, o profissional passa a lidar mais intensamente com os conflitos de interesse, disputas por espaço, recursos, reconhecimento e negociações. O que o sr.(a) pensa sobre esse aspecto da função do gestor?

2 Como o sr. (a) descreveria o ambiente político da organização.

3 Descreva as características de um profissional competente politicamente.

$4 \mathrm{O} \mathrm{Sr}(\mathrm{a})$ recebeu algum treinamento ou foi exposto a situações que the permitissem o desenvolvimento de competências políticas, antes de assumir seu cargo?

$5 \mathrm{Na}$ seleção ou promoção de profissionais para sua equipe, além dos aspectos técnicos, as questões dos relacionamentos sociais e políticos são levados em consideração? Por quê?

6 Identifique uma situação que o $\operatorname{Sr}($ a) precisou da competência política para atuar em uma negociação ou lidar com um conflito ou uma disputa. Qual era a situação? O que antecedeu o problema? Como foi o processo de resolução do problema? Qual foi o resultado?

$7 \mathrm{O} \mathrm{Sr}(\mathrm{a})$ se classificaria como um profissional competente politicamente? Se sim, isso ajudou? Se não, fez falta? Por quê?

8 Em um momento de conflito muito acirrado, como o problema era resolvido na empresa?

9 O comportamento político pode ser percebido de diferentes maneiras em razão da intenção e resultados das ações dos seus atores. Exemplifique como e quando alguns profissionais podem utilizar esse comportamento de maneira funcional ou disfuncional.

10 Em sua opinião, qual a melhor forma de incentivar o comportamento político funcional? E qual a melhor maneira de inibir o comportamento político disfuncional?

11 O que gera uma boa reputação para uma liderança?

12 Para o $\operatorname{Sr}(\mathrm{a})$., o que significa um líder legítimo? 


\section{Dados Quantitativos - (Essa parte será entregue para que ele responda)}

Solicitamos a gentileza de preencher o questionário abaixo considerando suas características no ambiente de trabalho. Basta responder uma escolha entre 1 e 7 levando em consideração o grau que você DISCORDA TOTALMENTE (1) da afirmativa ATÉ o grau em que você CONCORDA TOTALMENTE (7) com a afirmativa.

\begin{tabular}{|c|c|c|c|c|c|c|}
\hline 1 & 2 & 3 & 4 & 5 & 6 & 7 \\
\hline $\begin{array}{c}\text { Discordo } \\
\text { Totalmente }\end{array}$ & Discordo & $\begin{array}{c}\text { Discordo } \\
\text { Parcialmente }\end{array}$ & Neutro & $\begin{array}{c}\text { Concordo } \\
\text { Parcialmente }\end{array}$ & Concordo & $\begin{array}{c}\text { Concordo } \\
\text { Totalmente }\end{array}$ \\
\hline
\end{tabular}

\section{BLOCO 1}

1. Gasto muito tempo e esforço no trabalho me relacionando com outras pessoas.

\begin{tabular}{c|c|c|c|c|c|c|}
\hline 1 & 2 & 3 & 4 & 5 & 6 & 7 \\
\hline
\end{tabular}

2. Sou capaz de fazer com que as pessoas sintam-se confortáveis e a vontade ao meu lado.

\begin{tabular}{c|c|c|c|c|c|c|}
\hline 1 & 2 & 3 & 4 & 5 & 6 & 7 \\
\hline 3. Sou capaz de me comunicar com os outros de maneira fácil e efetiva \\
\hline 1 & 2 & 3 & 4 & 5 & 6 & 7 \\
\hline
\end{tabular}

4. Tenho facilidade em desenvolver um bom relacionamento com a maioria das pessoas

\begin{tabular}{|l|l|l|l|l|l|l|}
\hline 1 & 2 & 3 & 4 & 5 & 6 & 7 \\
\hline
\end{tabular}

5. Eu entendo muito bem as pessoas

\begin{tabular}{|c|c|c|c|c|c|c|}
\hline 1 & 2 & 3 & 4 & 5 & 6 & 7 \\
\hline
\end{tabular}

6. Criar relacionamentos com pessoas influentes no trabalho é uma tarefa fácil para mim

\begin{tabular}{|l|l|l|l|l|l|l|}
\hline 1 & 2 & 3 & 4 & 5 & 6 & 7 \\
\hline
\end{tabular}

7. Sou particularmente hábil em perceber as motivações e as agendas ocultas de outros

\begin{tabular}{|c|c|c|c|c|c|c|}
\hline 1 & 2 & 3 & 4 & 5 & 6 & 7 \\
\hline
\end{tabular}

8. Ao me comunicar com as pessoas tento ser verdadeiro no que digo e faço.

\begin{tabular}{c|c|c|c|c|c|c|} 
8. Ao me comunicar com as pessoas tento ser verdadeiro no que digo e faço. \\
\hline 1 & 2 & 3 & 4 & 5 & 6 & 7 \\
\hline
\end{tabular}

9. Desenvolvi uma grande rede de colegas e associados no trabalho que posso contar quando eu preciso que as coisas aconteçam

\begin{tabular}{c|c|c|c|c|c|c|}
\hline 1 & 2 & 3 & 4 & 5 & 6 & 7 \\
\hline
\end{tabular}

10. No trabalho, eu conheço e tenho bom relacionamento com várias pessoas importantes

\begin{tabular}{|c|c|c|c|c|c|c|}
\hline 1 & 2 & 3 & 4 & 5 & 6 & 7 \\
\hline
\end{tabular}

11. Passo muito tempo no trabalho desenvolvendo conexões com os outros

11. Passo muito tempo no trabalho desenvolvendo conexões com os outros
\begin{tabular}{c|c|c|c|c|c|c|}
\hline 1 & 2 & 3 & 4 & 5 & 6 & 7 \\
\hline 12. Sou bom em fazer as pessoas gostarem de mim \\
\hline 1 & 2 & 3 & 4 & 5 & 6 & 7 \\
\hline
\end{tabular}

13. É importante que as pessoas acreditem que eu sou sincero no que digo e faço

\begin{tabular}{|c|c|c|c|c|c|c|}
\hline 1 & 2 & 3 & 4 & 5 & 6 & 7 \\
\hline 14. Tento mostrar um interesse verdadeiro nas pessoas \\
\hline 1 & 2 & 3 & 4 & 5 & 6 & 7 \\
\hline
\end{tabular}

15. Sei utilizar bem meus relacionamentos para fazer as coisas acontecerem no trabalho.

\begin{tabular}{|c|c|c|c|c|c|c|}
\hline 1 & 2 & 3 & 4 & 5 & 6 & 7 \\
\hline
\end{tabular}

16. Tenho boa intuição e sou habilidoso em me apresentar aos outros. 


\begin{tabular}{|l|l|l|l|l|l|l|}
\hline 1 & 2 & 3 & 4 & 5 & 6 & 7 \\
\hline
\end{tabular}

17. Intuitivamente, eu entendo os outros, sabendo o que fazer ou dizer para influenciá-los

\begin{tabular}{c|c|c|c|c|c|c|}
\hline 1 & 2 & 3 & 4 & 5 & 6 & 7 \\
\hline
\end{tabular}

18. Presto bastante atenção nas expressões faciais das pessoas

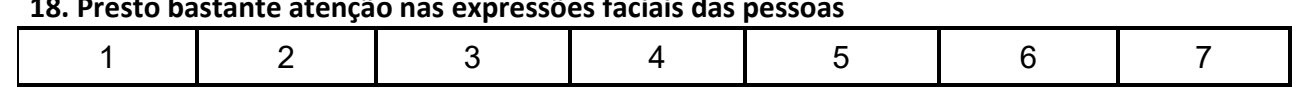

\section{BLOCO 2}

1. Sou visto como um profissional que obtém bons resultados para minha equipe e departamento

\begin{tabular}{|l|l|l|l|l|l|l|}
\hline 1 & 2 & 3 & 4 & 5 & 6 & 7 \\
\hline
\end{tabular}

2. As pessoas sentem que eu realizo coisas boas e importantes para a organização.

\begin{tabular}{|l|l|l|l|l|l|l|}
\hline 1 & 2 & 3 & 4 & 5 & 6 & 7 \\
\hline
\end{tabular}

3. Sou visto como uma pessoa habilidosa

3. Sou visto como uma pessoa habilidosa
\begin{tabular}{|c|c|c|c|c|c|c|}
\hline 1 & 2 & 3 & 4 & 5 & 6 & 7 \\
\hline
\end{tabular}

4. As pessoas me consideram uma pessoa confiável

4. As pessoas me consideram uma pessoa confiável
\begin{tabular}{|c|c|c|c|c|c|c|}
\hline 1 & 2 & 3 & 4 & 5 & 6 & 7 \\
\hline
\end{tabular}

5. Percebo que sou admirado e que sirvo de exemplo para algumas pessoas

\begin{tabular}{|l|l|l|l|l|l|l|}
\hline 1 & 2 & 3 & 4 & 5 & 6 & 7 \\
\hline
\end{tabular}

6. Minha experiência profissional é reconhecida pelas pessoas

\begin{tabular}{|l|l|l|l|l|l|l|}
\hline 1 & 2 & 3 & 4 & 5 & 6 & 7 \\
\hline
\end{tabular}

7. Tenho um conhecimento notório na minha área

\begin{tabular}{|c|c|c|c|c|c|c|}
\hline 1 & 2 & 3 & 4 & 5 & 6 & 7 \\
\hline
\end{tabular}

8. Sou reconhecido pela minha habilidade de perceber o ambiente e interagir socialmente

\begin{tabular}{|l|l|l|l|l|l|l|}
\hline 1 & 2 & 3 & 4 & 5 & 6 & 7 \\
\hline
\end{tabular}

9. As pessoas me vêem como um facilitador da interação social e união dos grupos

\begin{tabular}{|c|c|c|c|c|c|c|}
\hline 1 & 2 & 3 & 4 & 5 & 6 & 7 \\
\hline
\end{tabular}

\section{BLOCO 3}

1. As pessoas da minha equipe querem que eu continue no meu cargo

\begin{tabular}{|l|l|l|l|l|l|l|}
\hline 1 & 2 & 3 & 4 & 5 & 6 & 7 \\
\hline
\end{tabular}

2. As pessoas da minha equipe julgam que eu mereço a posição que ocupo

\begin{tabular}{|l|l|l|l|l|l|l|}
\hline 1 & 2 & 3 & 4 & 5 & 6 & 7 \\
\hline
\end{tabular}

3. As pessoas da minha equipe acreditam que eu facilito o alcance de metas

\begin{tabular}{|l|l|l|l|l|l|l|}
\hline 1 & 2 & 3 & 4 & 5 & 6 & 7 \\
\hline
\end{tabular}

4. As pessoas consideram o meu comportamento como ético

\begin{tabular}{|l|l|l|l|l|l|l|}
\hline 1 & 2 & 3 & 4 & 5 & 6 & 7 \\
\hline
\end{tabular}

5. As pessoas da minha equipe são tratadas com dignidade e respeito por $\mathrm{mim}$.

5. As pessoas da minha equipe são tratadas com dignidade e respeito por mim.
\begin{tabular}{|c|c|c|c|c|c|c|}
\hline 1 & 2 & 3 & 4 & 5 & 6 & 7 \\
\hline
\end{tabular}

6. Meus valores morais são percebidos como similares aos valores dos membros do meu grupo

\begin{tabular}{|l|l|l|l|l|l|l|}
\hline 1 & 2 & 3 & 4 & 5 & 6 & 7 \\
\hline
\end{tabular}




\section{VERSÃO AVALIAÇÃO DE PARES}

Solicitamos a gentileza de preencher o questionário abaixo considerando as características do seu par no ambiente de trabalho. Basta responder uma escolha entre 1 e 7 levando em

consideração o grau que você DISCORDA TOTALMENTE (1) da afirmativa ATÉ o grau em que você CONCORDA TOTALMENTE (7) com a afirmativa.

BLOCO 1 - COMPETÊNCIA POLÍTICA

1. Ele (a) gasta muito tempo e esforço no trabalho se relacionando com outras pessoas.

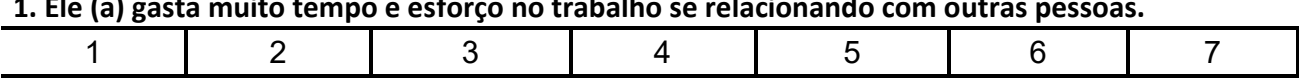

2. Ele(a) faz com que as pessoas sintam-se confortáveis e a vontade ao seu lado.

\begin{tabular}{c|c|c|c|c|c|c}
\hline 1 & 2 & 3 & 4 & 5 & 6 & 7 \\
\hline 3. Ele(a) se comunica com os outros de maneira fácil e efetiva \\
\hline 1 & 2 & 3 & 4 & 5 & 6 & 7 \\
\hline
\end{tabular}

4. Ele (a) tem facilidade em desenvolver um bom relacionamento com a maioria das pessoas

\begin{tabular}{|l|l|l|l|l|l|l|}
\hline 1 & 2 & 3 & 4 & 5 & 6 & 7 \\
\hline
\end{tabular}

5. Ele (a) entende muito bem as pessoas

\begin{tabular}{c|c|c|c|c|c|c|}
\hline 1 & 2 & 3 & 4 & 5 & 6 & 7 \\
\hline 6 \\
6 6. Ele sabe criar facilmente relacionamentos com pessoas influentes no trabalho \\
\hline 1 & 2 & 3 & 4 & 5 & 6 & 7 \\
\hline
\end{tabular}

7. Ele(a) é particularmente hábil em perceber as motivações e as agendas ocultas de outros

\begin{tabular}{|c|c|c|c|c|c|c|}
\hline 1 & 2 & 3 & 4 & 5 & 6 & 7 \\
\hline
\end{tabular}

8. Ao se comunicar com as pessoas, ele (a) tenta ser verdadeiro no que diz e faz.

\begin{tabular}{c|c|c|c|c|c|c|}
\hline 1 & 2 & 3 & 4 & 5 & 6 & 7 \\
\hline
\end{tabular}

9. Ele(a) desenvolve uma grande rede de colegas e associados no trabalho que ele(a) pode contar quando precisa que as coisas aconteçam

\begin{tabular}{c|c|c|c|c|c|c|}
\hline 1 & 2 & 3 & 4 & 5 & 6 & 7 \\
\hline
\end{tabular}

10. No trabalho, ele (a) conhece e tem bom relacionamento com várias pessoas importantes

\begin{tabular}{|c|c|c|c|c|c|c|}
\hline 1 & 2 & 3 & 4 & 5 & 6 & 7 \\
\hline
\end{tabular}

11. Ele (a) passa muito tempo no trabalho desenvolvendo conexões com os outros

\begin{tabular}{|c|c|c|c|c|c|c|}
\hline 1 & 2 & 3 & 4 & 5 & 6 & 7 \\
\hline 12. Ele (a) é bom em fazer as pessoas gostarem dele \\
\hline 1 & 2 & 3 & 4 & 5 & 6 & 7 \\
\hline
\end{tabular}

13. Para ele (a) é importante que as pessoas acreditem que ele é sincero no que diz e faz

\begin{tabular}{|c|c|c|c|c|c|c|}
\hline 1 & 2 & 3 & 4 & 5 & 6 & 7 \\
\hline 14. Ele(a) tenta mostrar um interesse verdadeiro nas pessoas \\
\hline 1 & 2 & 3 & 4 & 5 & 6 & 7 \\
\hline
\end{tabular}

15. Ele sabe utilizar bem seus relacionamentos para fazer as coisas acontecerem no trabalho.

\begin{tabular}{|c|c|c|c|c|c|c|}
\hline 1 & 2 & 3 & 4 & 5 & 6 & 7 \\
\hline 16. Ele (a) tem boa intuição e é habilidoso(a) em se apresentar aos outros. \\
\hline 1 & 2 & 3 & 4 & 5 & 6 & 7 \\
\hline
\end{tabular}

17. Intuitivamente, ele (a) entende os outros, sabendo o que fazer ou dizer para influenciá-los

\begin{tabular}{l|l|l|l|l|l|l|}
\hline 1 & 2 & 3 & 4 & 5 & 6 & 7 \\
\hline
\end{tabular}


18. Ele (a) presta bastante atenção nas expressões faciais das pessoas

\begin{tabular}{|l|l|l|l|l|l|l|}
\hline 1 & 2 & 3 & 4 & 5 & 6 & 7 \\
\hline
\end{tabular}

\section{BLOCO 2 - REPUTAÇÃO}

1. Ele (a) é visto como um profissional que obtém bons resultados para sua equipe $\mathrm{e}$ departamento

\begin{tabular}{|l|l|l|l|l|l|l|}
\hline 1 & 2 & 3 & 4 & 5 & 6 & 7 \\
\hline
\end{tabular}

2. As pessoas sentem que ele(a) realiza coisas boas e importantes para a organização.

\begin{tabular}{|l|c|c|c|c|c|c|}
\hline 1 & 2 & 3 & 4 & 5 & 6 & 7 \\
\hline 1 & 2 & 3 & 4 & 5 & 6 & 7 \\
\hline
\end{tabular}
\begin{tabular}{|l|c|c|c|c|c|}
\hline 3. Ele (a) é visto como uma pessoa habilidosa \\
\hline
\end{tabular}

4. As pessoas o(a) consideram uma pessoa confiável

4. As pessoas o(a) consideram uma pessoa confiável
\begin{tabular}{|c|c|c|c|c|c|c|}
\hline 1 & 2 & 3 & 4 & 5 & 6 & 7 \\
\hline
\end{tabular}

5. Ele (a) é admirado e serve de exemplo para algumas pessoas.

\begin{tabular}{|c|c|c|c|c|c|c|}
\hline 1 & 2 & 3 & 4 & 5 & 6 & 7 \\
\hline
\end{tabular}

6. A experiência profissional dele (a) é reconhecida pelas pessoas

\begin{tabular}{|l|l|l|l|l|l|l|}
\hline 1 & 2 & 3 & 4 & 5 & 6 & 7 \\
\hline
\end{tabular}

7. Ele (a) tem um conhecimento notório na sua área

\begin{tabular}{|c|c|c|c|c|c|c|}
\hline 1 & 2 & 3 & 4 & 5 & 6 & 7 \\
\hline
\end{tabular}

8. Ele (a) é reconhecido por sua habilidade em perceber o ambiente e interagir socialmente

\begin{tabular}{|c|c|c|c|c|c|c|}
\hline 1 & 2 & 3 & 4 & 5 & 6 & 7 \\
\hline
\end{tabular}

9. Ele (a) é visto como um facilitador da interação social e união dos grupos

\begin{tabular}{|l|l|l|l|l|l|l|}
\hline 1 & 2 & 3 & 4 & 5 & 6 & 7 \\
\hline
\end{tabular}

\section{BLOCO 3 - ATRIBUIÇÃO DE LEGITIMIDADE}

1. Eu quero que ele(a) continue em seu cargo

\begin{tabular}{|l|l|l|l|l|l|l|}
\hline 1 & 2 & 3 & 4 & 5 & 6 & 7 \\
\hline
\end{tabular}

2. Ele(a) merece a posição que ocupa

\begin{tabular}{|c|c|c|c|c|c|c|}
\hline 1 & 2 & 3 & 4 & 5 & 6 & 7 \\
\hline
\end{tabular}

\section{Ele(a) facilita o alcance de metas}

3. Ele(a) facilita o alcance de metas
\begin{tabular}{|c|c|c|c|c|c|c|}
\hline 1 & 2 & 3 & 4 & 5 & 6 & 7 \\
\hline
\end{tabular}

4. Ele (a) se comporta de maneira ética

4. Ele (a) se comporta de maneira ética
\begin{tabular}{|c|c|c|c|c|c|c|}
\hline 1 & 2 & 3 & 4 & 5 & 6 & 7 \\
\hline
\end{tabular}

\section{Ele(a) trata a todos com dignidade e respeito}

\begin{tabular}{|c|c|c|c|c|c|c|}
\hline 1 & 2 & 3 & 4 & 5 & 6 & 7 \\
\hline \multicolumn{7}{|c|}{ 6.Seus valores morais se parecem com os meus } \\
\hline 1 & 2 & 3 & 4 & 5 & 6 & 7 \\
\hline
\end{tabular}

7. Ele (a) transmite confiança e neutralidade

\begin{tabular}{|c|c|c|c|c|c|c|}
\hline 1 & 2 & 3 & 4 & 5 & 6 & 7 \\
\hline
\end{tabular}

